\title{
TECNOLOGIA SIDERÚRGICA
}

DÁRIO MOREIRA PINTO JUNIOR DORLIVETE MOREIRA SHITSUKA RICARDO SHITSUKA WELINGTON LEÔNCIO COSTA

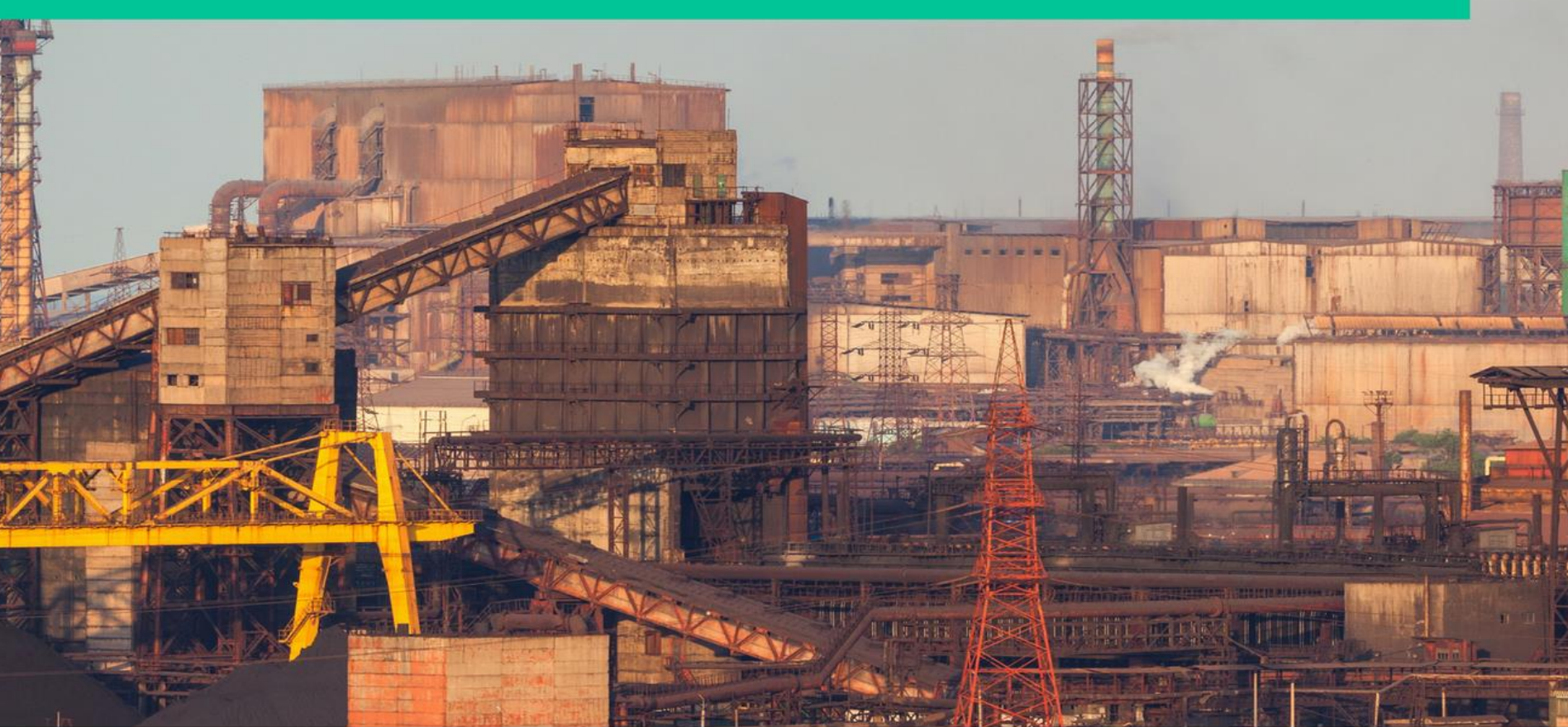

EDITORA POISSON 
Dário Moreira Pinto Júnior

Dorlivete Moreira Shitsuka

Ricardo Shitsuka

Welington Leôncio Costa

\section{Tecnologia siderúrgica}

1a Edição

Belo Horizonte

Poisson

2018 


\section{Conselho Editorial}

Dr. Antônio Artur de Souza - Universidade Federal de Minas Gerais Dra. Cacilda Nacur Lorentz - Universidade do Estado de Minas Gerais Dr. José Eduardo Ferreira Lopes - Universidade Federal de Uberlândia Dr. Otaviano Francisco Neves - Pontifícia Universidade Católica de Minas Gerais

Dr. Luiz Cláudio de Lima - Universidade FUMEC Dr. Nelson Ferreira Filho - Faculdades Kennedy

Dados Internacionais de Catalogação na Publicação (CIP)

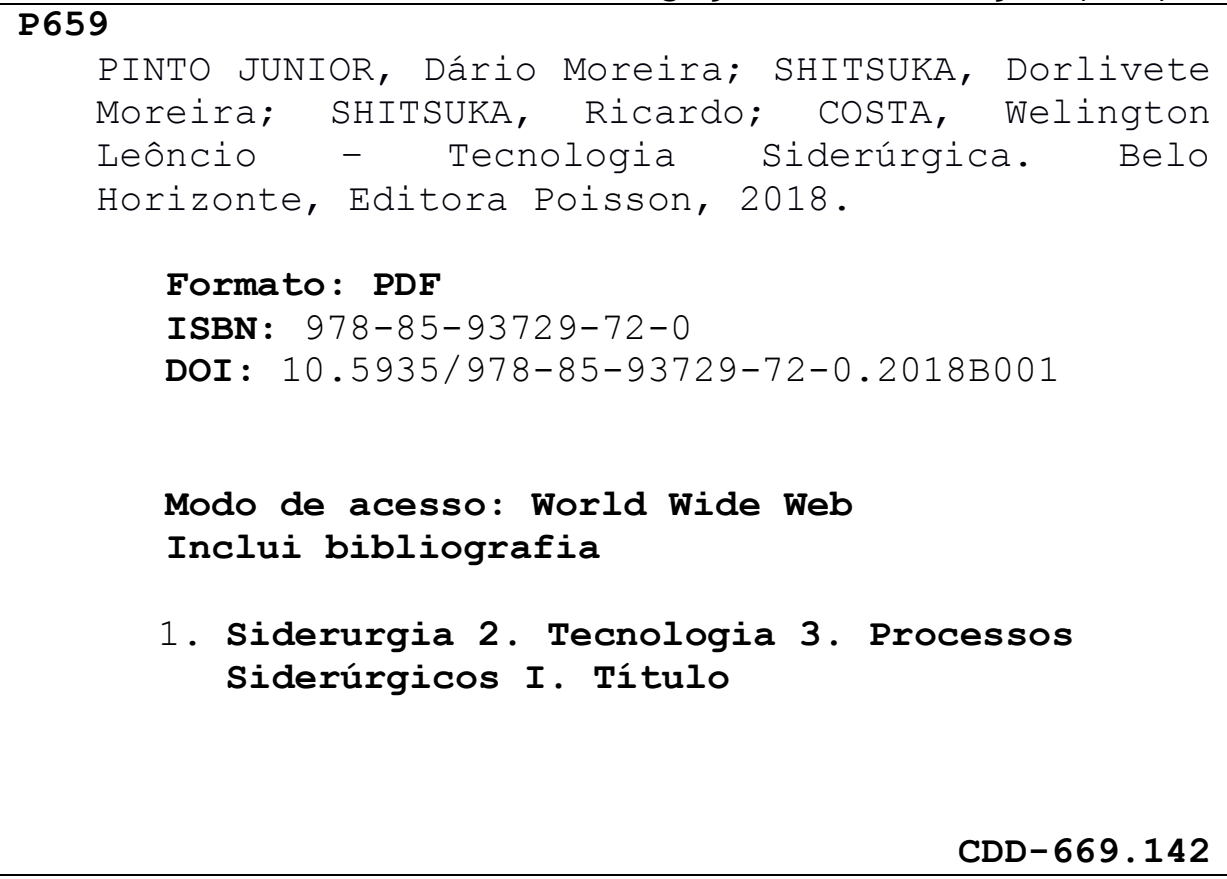




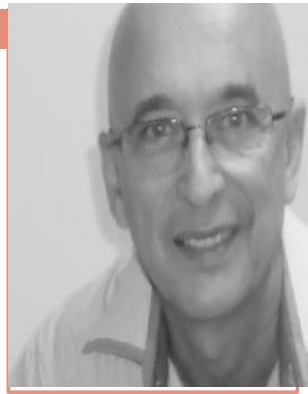

Dário Moreira Pinto Júnior

Doutor em Engenharia

Mestre em Engenharia Metalúrgica Especialização em Gestão de Pessoas

Graduação em Engenharia Metalúrgica e em Administração Empresas

Engenheiro Companhia Siderúrgica Nacional por 25 anos

Docente no Ensino Superior

Consultor de empresas do SEBRAE Nacional

Especialista do INMETRO

Avaliador "Ad hoc" do INEP/MEC

dariompj@yahoo.com.br

Dorlivete Moreira Shitsuka

Mestre em Ensino de Ciências.

É Pós-Graduada na Especialização "Lato sensu" em Sistemas de Informação,

em Redes de Computadores, em Informática em Educação, em Educação

Infantil e em, Administração Escolar e Inspeção Escolar.

Possui graduações em: Licenciatura em Computação, Biblioteconomia e

Documentação e, em Pedagogia.

É professora Universitária Tutora de EAD.

É autora e co-autora de várias obras e palestrante.

É pesquisadora do Grupo de Pesquisas em Metodologias em Ensino e

Aprendizagem em Ciências - MEAC.

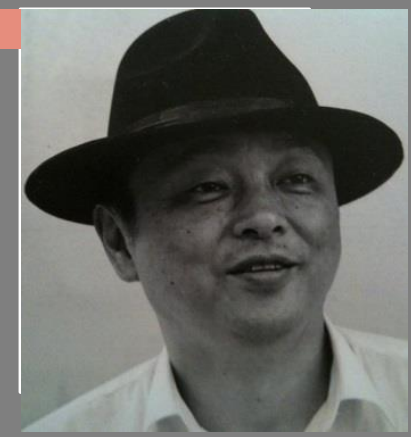

Ricardo Shitsuka

Doutor em Ensino de Ciências e Matemática Mestre em Engenharia de

Materiais e Metalurgia.

Possui pós-graduação especialização em: "Tecnologias Educacionais",

"Sistemas de Informação", "Design Instrucional para EAD", "Redes de

Computadores", "e-business", "Informática em Educação", "Tecnologia,

Formação de Professores e Sociedade", "Educação Infantil" e, em

"Administração Escolar e Inspeção Escolar".

É graduado em: "Engenharia de Metalúrgica e de Materiais", "Odontologia",

"Licenciatura em Computação" e, em "Pedagogia".

É pesquisador e professor Adjunto IV na Universidade Federal de Itajubá -

UNIFEI - campus Itabira.

Atua como Professor no Programa de Pós-Graduação em Educação em

Ciências (PPGEC da UNIFEI) Campus Itabira.

Líder do Grupo de Pesquisas MEAC

É editor da revista Research, Society and Development e atua como avaliador

"Ad hoc" para o DAES/INEP/MEC

rshitsuka@yahoo.com

\section{Welington Leôncio Costa}

Mestrado em Gestão e Estratégia em Negócios

Pós-graduação em Formação de Professor do Ensino Superior

Pós-Graduação em Programa Especial de Formação Pedagógica de Docentes

Pós-Graduação em Engenharia Econômica

Graduação em Ciências Econômicas

Consultor de Empresas

Diretor dos Institutos de Ciências Sociais e Humanas e de Ciência da Saúde do

Centro Universitário Geraldo Di Biase- UGB

welec@ig.com.br

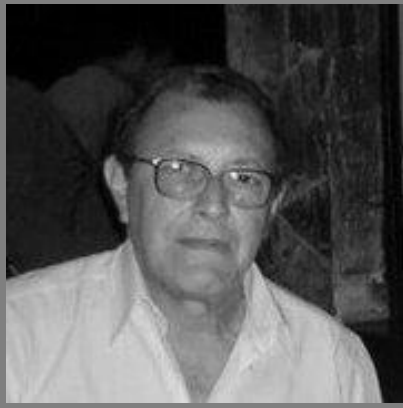




\section{SUMÁRIO}

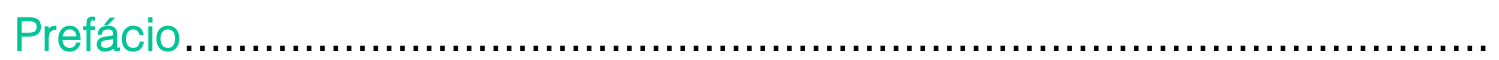

Lista de figuras e tabelas .....................................................................

Capítulo 1: Breve contextualização da siderurgia..................................... 13

Capítulo 2: Produtos de aço, mercado e propriedades ............................. 21

Capítulo 3: Produtos de ferro fundido, mercado e propriedades ............... 28

Capítulo 4: Processos siderúrgicos a partir da redução direta do minério 35

Capítulo 5: Principais equipamentos siderúrgicos ................................. 40

Capítulo 6: Processos de alto forno ........................................................ 49

Capítulo 7: Processos a partir de sucata de aço .................................... 54

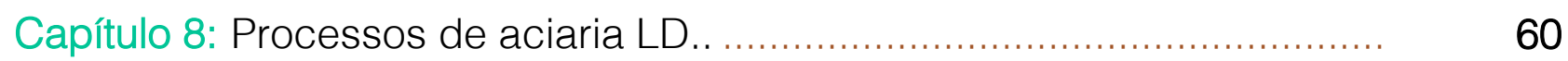

Capítulo 9: Processos de lingotamento convencional e contínuo ............... 67

Capítulo 10: Processos de laminação a quente ....................................... 75

Capítulo 11: Processo de laminação a frio ........................................... 82

Capítulo 12: Processo de recozimento ................................................. 90

Capítulo 13: Processo de estanhamento ........................................... 107

Capítulo 14: Processo de zincagem ....................................................... 119 


\section{SUMÁRIO}

Capítulo 15: Estampabilidade de aços

Capítulo 16: Trefilação de aços

Capítulo 17: Ensaios mecânicos em aço

Capítulo 18: Logística em siderurgia

Capítulo 19: Saúde, segurança e higiene na siderurgia 


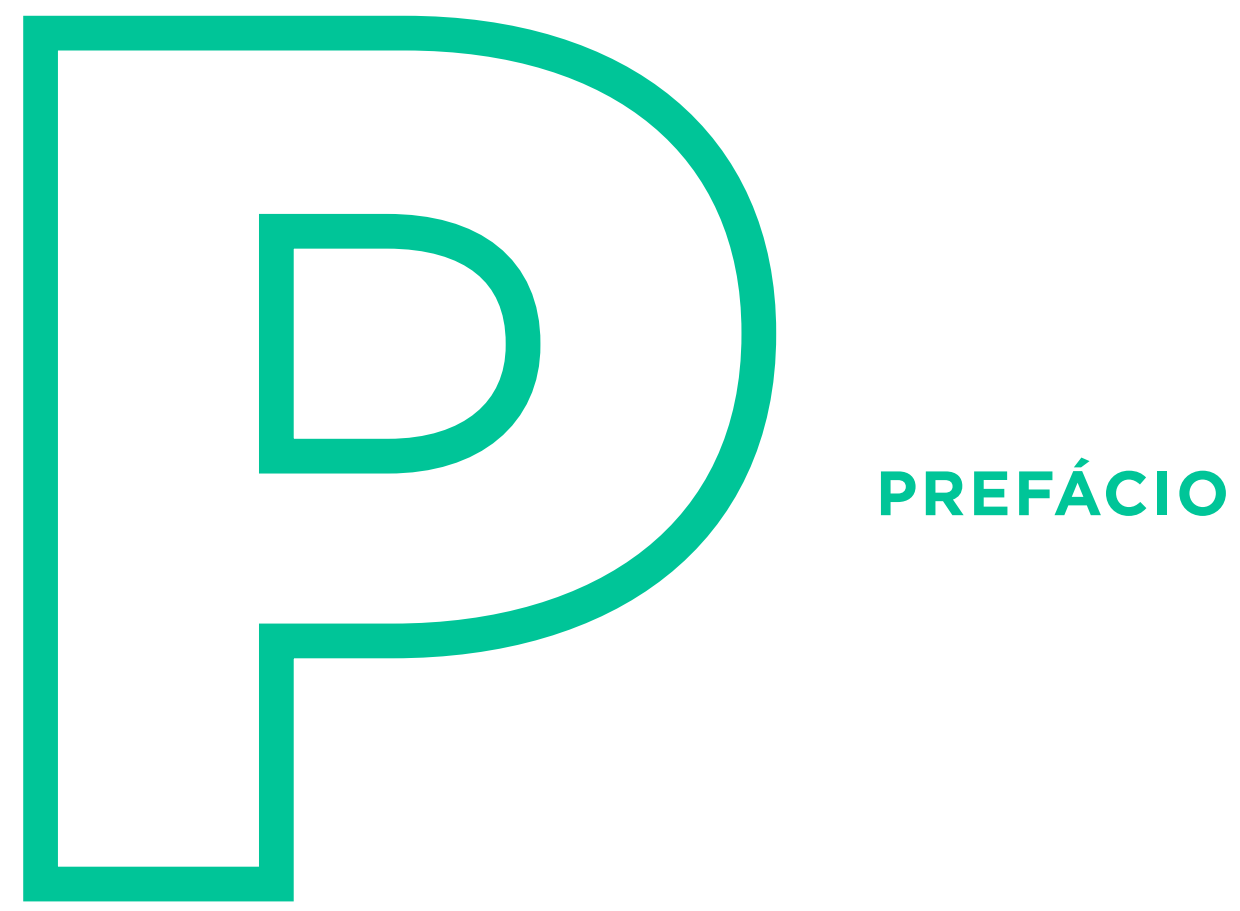

Esta obra é um passeio pela tecnologia siderúrgica. Ela é destinada aos estudantes do nível médio técnico, tecnológico e engenheiros que estão interessados em se iniciar nesta tecnologia.

Ferros fundidos e aços são ligas de ferro que são materiais para construção mecânica em engenharia e tecnologia e que são amplamente utilizadas na indústria mecânica para a fabricação de peças, equipamentos e instalações devido às suas propriedades mecânicas e propriedades em geral. Entre as razões para tal emprego, estão: a facilidade de se dar forma aos produtos desses materiais e ao fato dos mesmos conservarem o formato seja de tubos, perfilados, cantoneiras, vigas e peças em geral e na construção civil em estruturas prediais, de galpões, pontes, viadutos e em reforço de pisos industriais e bases para instalação de máquinas pesadas. Na mobilidade utiliza-se tanto na construção rodoviária 
quanto na ferroviária e em outros meios de transporte.

A obra se inicia com breves aspectos históricos da siderurgia, passa pelos produtos de aço e ferro fundido existentes no mercado e suas propriedades e segue pelos processos de produção passando pela siderurgia integrada até o lingotamento que inclui os altos-fornos, Aciarias LD, Lingotamento convencional e lingotamento contínuo, e siderurgia à base de sucata em fornos elétricos.

Na continuidade a obra passa pela laminação de chapas grossas, laminação de chapas finas, bobinas, linhas de galvanização e produção de folhas de flandres. Fornos de recozimento e reaquecimento. Produção de perfis: trilhos, vigas em I, vigas em T, cantoneiras, perfilados em geral. Qualidade, produtividade e produtos em geral.

Outros aspectos importantes nesta obra são: a questão da automação e sistemas integrados computacionais com as informações tramitando pelas redes de computadores pela nuvem da Internet, a questão dos despachos, embalagem, logística e transportes e a questão da sustentabilidade.

Os autores agradecem as sugestões e comentários para melhorar a obra e esperam que a mesma seja útil na formação dos técnicos tão necessários para o País. 


\section{LISTAS DE FIGURAS E TABELAS}

\section{LISTA DE FIGURAS}

Figura 1: apresenta um exemplo de lingotes de ferro fundido

Figura 2: exemplos ilustrativos de aplicação de peças fabricadas em ferro fundido

Figura 3: representação esquemática de uma escavadeira

Figura 4: representação esquemática de uma pá carregadeira

Figura 5: representação esquemática de uma empilhadeira

Figura 6: representação esquemática de um pórtico (ponte rolante de céu aberto) 
Figura 7: representação esquemática de uma correia transportadora para transporte de minério

Figura 8: é uma representação esquemática de um britador de mandíbulas típico

Figura 9: visão esquemática de uma panela de gusa

Figura 10: visão esquemática de um carro torpedo típico

Figura 11: visão esquemática de um conversor LD com a lança de oxigênio puro posicionada no momento do sopro

Figura 12: visão esquemática de um equipamento de lingotamento continuo

Figura 13: visão esquemática de um alto forno mostrando suas partes principais

Figura 14: variação da temperatura ao longo da altura do alto forno

Figura 15: visão esquemática de um convertedor LD em corte mostrando suas partes principais

Figura 16: exemplos ilustrativos de dois tipos usuais de lingoteiras cônicas, sendo (A) representando uma lingoteira com base maior voltada para baixo e (B) uma lingoteira com base maior voltada para cima

Figura 17: principais partes da instalação de um processo de lingotamento contínuo

Figura 18: representação da variação que ocorre na forma e tamanho dos grãos antes e após o processo de deformação a quente

Figura 19: Ilustração de um conjunto de cilindros de trabalho e encosto

Figura 20: exemplo de um cilindro mostrando suas partes principais (corpo, pescoço e trevo)

Figura 21: influência da temperatura de recozimento nas propriedades mecânicas de um aço no estado "encruado"

Figura 22: ilustração de como se processa o mecanismo de transmissão do calor durante o processo de recozimento

Figura 23: visão geral de um forno tipo campânula, onde pode-se visualizar o abafador, os convectores, o termopar e a ventoinha da base

Figura 24: comparação entre os perfis térmicos dos processos de alta convecção (hidrogênio puro) e fornos convencionais (atmosfera de HN) 
Figura 25: exemplo típico de uma base de recozimento. São mostrados detalhes do termopar da base, ventoinha e uma bobina posicionada

Figura 26: modelo ilustrativo de um abafador simples

Figura 27: perfis térmicos em diferentes pontos ao longo das bobinas (carga) durante o processo de recozimento

Figura 28: visão sucinta de uma linha de recozimento contínuo

Figura 29: visão interna do forno de uma linha de recozimento continuo de chapas finas

Figura 30: representação esquemática de uma cuba eletrolítica mostrando os eletrodos positivo e negativo e uma fonte de alimentação

Figura 31: tanque de eletrodeposição de uma linha de estanhamento eletrolítico mostrando as principais partes (tanque, rolos condutores, ponte de anodos e anodos de estanho)

Figura 32: perfil de uma folha estanhada e de uma folha cromada, em corte, mostrando as camadas formadas em uma de suas superfícies

Figura 33: Fluxo de produçao do produto folha estanhada

Figura 34: representação de três diferentes técnicas de combater a corrosão

Figura 35: ilustração de um pote com o banho de zinco num processo de zincagem por imersão a quente. Pode-se visualizar o posicionamento do rolo submerso, a navalha de ar e os eletrodos de aquecimento do banho

Figura 36: amostra de aço revestido com zinco com um risco na superfície (a) e tabela com potenciais eletroquímicos de alguns elementos químicos (b)

Figura 37: principais tipos de revestimentos de uma linha de zincagem por imersão a quente (liso, minimizado e cristais normais)

Figura 38: representação de uma operação de corte numa prensa onde pode se visualizar as laminas e a folga entre elas

Figura 39: detalhes da operação de entalhe

Figura 40: representação esquemática dos detalhes de uma operação de puncionamento

Figura 41: dobra a partir de uma chapa plana

Figura 42: ilustra as tensões que ocorrem durante o processo de trefilação 
Figura 43: desenho esquemático de uma fieira

Figura 44: descrição dos símbolos (letra ou número) que compõe a especificação do eletrodo revestido segundo normas ABNT

\section{LISTA DE TABELAS}

Tabela I: comparação entre os fornos de recozimento convencional de tubo radiante e de chama direta

Tabela II: Exemplos de espessuras de folhas metálicas utilizadas na prática bem como os valores de massa correspondentes

Tabela III: dureza Superficial Rockwell para as folhas metálicas de simples e dupla-redução

Tabela IV: valores dos limites de escoamento das folhas metálicas de dupla-redução

Tabela V: tipos e valores dos revestimentos (iguais) usuais das folhas metálicas

Tabela Vl: tipos e valores dos revestimentos diferenciais das folhas metálicas estanhadas

Tabela VII: valores máximos e mínimos de cromo metálico e óxido de cromo das folhas cromadas

Tabela VIII: tipos de revestimentos por imersão a quente

Tabela IX: revestimentos aplicados aos produtos Galvanneal

Tabela X: revestimentos aplicados aos produtos Galvalume ${ }^{\circledR}$

Tabela XI: principais riscos e contramedidas em postos de trabalho da siderurgia 


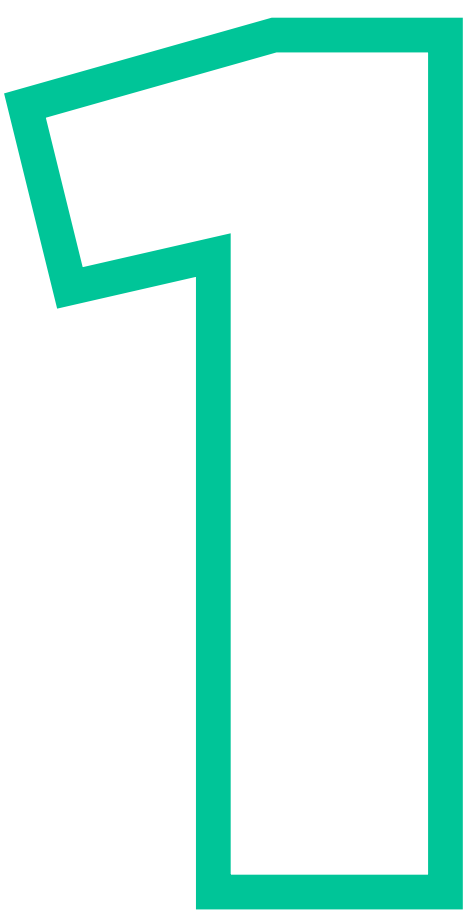

\section{BREVE CONTEXTUALIZAÇÃO DA SIDERURGIA}

\section{Fala sobre:}

_ Introdução

_ Histórico da siderurgia

_ O aço como uma liga Fe-C

_ Utilização do aço nas industrias

_ Dicas sobre segurança

_ Referências Bibliográficas

_ Exercícios resolvidos 


\section{INTRODUÇÃO}

O aspecto histórico é sempre um incentivo para as pessoas que se iniciam numa determinada área. Por meio dele é possível ter a noção de onde e como tudo começou, bem como sua contextualização. Quando se fala em ferro, pode-se estar referindo ao elemento químico ferro (Fe) ou a um material que tem como componente principal esse elemento.

O ferro é um elemento químico de número atômico 26 e massa atômica aproximadamente 56; é um dos elementos mais presentes na crosta terrestre, estando em quarto lugar entre os mesmos. Às vezes, ele pode aparecer na forma pura, como por exemplo, nos meteoros que caem na Terra. Já na natureza, normalmente, ele existe na forma de óxidos. Óxidos são compostos químicos formados pela ligação entre o oxigênio e outro elemento, em quantidades que permitam certo grau de estabilidade. Este é o caso do óxido de ferro (Fe2O3), que também é conhecido como hematita.

O óxido de ferro (Fe2O3) pode ser utilizado como pigmento de cor vermelha em tintas. Existem outros óxidos de ferro com algum grau de estabilidade que são: Fe3O4 (que tem os nomes: magnetita, ou oxido de ferro II e III) e o FeO (óxido de ferro II).

No início da história dos metais na humanidade, quando os homens faziam fogueira junto aos locais onde havia o minério de ferro, muitas vezes se juntavam as condições de calor, carvão e minério de ferro, de modo a ocorrer uma reação química de redução e se formar o ferro puro junto ao local da fogueira.

Esse aspecto histórico ocorreu possivelmente nas civilizações antigas, como é o caso do Egito e posteriormente a China, onde há milhares de anos atrás já se conhecia o ferro. A história da humanidade considera um período como sendo da Idade do Ferro, quando os povos produziam ferro para uso na fabricação de armas, instrumentos para a lavoura, para instalações de grades, portões, pregos e para a cutelaria.

Com o passar do tempo, foram descobertos processos que podiam acelerar a fabricação do ferro, dentre os quais, os processos de fabricação com fornos e sopro de fole, que eram conhecidos como Forja Catalã da Idade Média.

A ideia do sopro para fazer a redução ganhou força e aumento de produtividade com o surgimento dos altos-fornos que produzem ferro gusa (ferro com grande quantidade de carbono sobrenadante, próximo ao limite de solubilidade). Com o aumento da produtividade possibilitada por esses equipamentos, precisou-se também de processos para transformar gusa em aço, por meio do sopro e ar.

Em princípio, pode parecer estranho que se retire oxigênio do ferro e depois se faça o sopro de oxigênio para alcançar o ferro mais purificado que é transformado em aço; é uma liga de ferro com carbono, mas com baixíssima quantidade deste elemento químico. Ocorre que, quando o ferro gusa 
sai dos altos-fornos com uma quantidade muito elevada de carbono, ele não é utilizável na maioria das aplicações, pois a gusa não conta com as propriedades mecânicas do aço (limite de resistência à tração, limite de escoamento, dureza, resistência, trabaIhabilidade e estampabilidade) que são necessárias para a maioria das aplicações. Torna-se necessário transformar a gusa em aço e isso é feito por meio do sopro de oxigênio, que nos primeiros minutos queima preferencialmente o carbono e não o ferro puro líquido do banho metálico da gusa. O processo de sopro é interrompido no final, antes que comece a oxidar demais o banho. Este processo de sopro, com alta produtividade, foi desenvolvido na Alemanha e denominado de Bessemer.

No final da Idade Moderna, surgiu o forno Bessemer de sopro de ar, por baixo do forno com aumento substancial de produção. Posteriormente, no século XIX, surgiu o processo Lintz e Donawitz (LD), no qual se fazia o sopro de oxigênio por meio de uma lança que entrava no forno pela parte superior. Este forno passou a se denominar de conversor ou convertedor LD.

Atualmente, existem processos industriais que são destinados a retirar o oxigênio dos óxidos de ferro. Por meio desses processos industriais, pode-se fabricar o aço, que é uma liga. Uma mistura de ferro com carbono, sendo que este em pequenas porcentagens, pode afetar bastante as propriedades mecânicas (resistência à tração, limite de resistência, dureza e resistência à fadiga dos aços).
Aços são as ligas ferro-carbono mais conhecidas pelas pessoas, porém existem outras ligas de ferro como é o caso dos ferros fundidos que possuem porcentagens de carbono mais elevadas que o aço. Aços, em geral, têm menos que 1\% de carbono em peso em sua composição química, ao passo que os ferros fundidos podem conter até o máximo do limite de solubilidade do carbono no ferro, que é de $6,7 \%$. Em geral, os ferros fundidos têm em torno de $2 \%$ a $5 \%$ de carbono dissolvido em sua estrutura de material.

É importante salientar que a produção mundial de aço bateu novo recorde, subindo para mais de 1,6 bilhões de toneladas (REUTERS, 2014).

O aço e os ferrosos são os materiais mais reciclados do mundo e isso os torna interessantes, pois, sabe-se que os recursos existentes no Planeta Terra são limitados e que necessitam de sustentabilidade. Este é um conceito amplo e importante para a sociedade; está relacionada com o próprio futuro da humanidade, podendo ter várias dimensões, como é o caso da sustentabilidade financeira, comercial, política, social e nas questões ambientais. Há também o desenvolvimento sustentável, que é o processo ou conjunto de ações para se alcançar a sustentabilidade (SACHS, 2000, COUTINHO; SHITSUKA, 2011, BOFF, 2012).

A siderurgia é a fabricação de aço e das ligas de ferro. O objetivo do presente capítulo é apresentar aspectos históricos e cálculos envolvendo porcentagens na siderurgia, para que o leitor tenha noção de 
como se iniciou a fabricação dos produtos siderúrgicos, a importância dos mesmos no contexto atual e como são trabalhadas as porcentagens em peso nesse material.

Vale ressaltar que o Brasil é um país com muito minério de ferro, muitas siderúrgicas e é um grande produtor de aço e ferro. A produção de aço bruto em nosso País, em julho de 2014 foi de 19.678t (AÇO BRASIL, 2014). A produção brasileira de produtos siderúrgicos é grande e o País está entre os maiores fabricantes do mundo.

\section{SIDERURGIA NA HISTÓRIA}

A origem da palavra siderurgia vem de espaço sideral. Ocorre que cometas, asteroides e fragmentos de material que vinham do espaço e alcançavam nosso planeta normalmente continham o ferro, que é um elemento químico muito abundante no Universo. Desta forma, associou-se, desde a antiguidade, o ferro ao espaço sideral.

A história do ferro começou há mais de 3.000 anos atrás, sendo datada de 1.200 a.C. Desta forma, essa história é antiga, havendo a possibilidade de melhorar e aperfeiçoar os processos, os reatores e as produtividades. Houve um período da história humana em que o homem começou a trabalhar o ferro, no Oriente Médio, por volta de 1.200 a.C. No Norte da Europa, o trabalho com o ferro começou por volta do ano 700 a.C. Na Península Ibérica, esse trabalho começou por volta de 1000-900 a.C., graças aos Celtas. Na
Idade Média, o ferro foi utilizado para as charruas, com relhas de ferro, ferraduras, grades e armas (MENDES, 2000).

Nos primórdios, os processos de produção do ferro eram mais simples, com uso de carvão e minério, sem a preocupação com rendimentos, com arranjos físicos. O que importava para os ferreiros era alcançar a fabricação do material que seria transformado em produtos.

Com o passar dos séculos, os fornos foram tomando a forma de reatores mais eficientes, de alta produtividade, bem como surgiu uma grande gama de produtos e materiais que possuíam uma quantidade grande de ligas de ferro com as mais diversas propriedades e que caracterizam as siderúrgicas atuais. Surgiram também processos térmicos (têmpera, revenimento e recozimento) e mecânicos (processos de encruamento, deformação a frio e deformação a quente) que possibilitaram a alteração das propriedades das ligas de ferro, de modo a torná-los mais duros, resistentes (exemplos: tratamento de têmpera, martêmpera e austêmpera), ou mais macios e mais maleáveis (exemplos: tratamento de recozimento e revenimento).

\section{O AÇO NOS DIAS ATUAIS}

Aço é uma liga ferro-carbono. Ligas são materiais que contém um metal e outro elemento que pode ser metal ou não metal. No caso do aço, este é uma liga do metal ferro com o não metal carbono. Entre as ligas de ferro, podem existir outras ligas, 
como: aços inoxidáveis, ou aços inox, que contém além do ferro, o cromo e o níquel. Para se ter um aço inox é preciso ter pelo menos $11 \%$ de cromo em peso.

Aços e ferros fundidos são os materiais de engenharia e tecnologia mais empregados pela indústria mundial. Eles são fabricados nas siderúrgicas. O aço é usado na fabricação de peças, dispositivos e instalações. Ele conserva a forma depois de moldado, tem boa resistência ao desgaste, bom limite de resistência à deformação e, dentre os materiais, é relativamente barato e pode ser fabricado com facilidade nas usinas siderúrgicas.

Definição: Aço é uma liga de ferro e carbono contendo até $2,11 \%$ em peso de carbono. Existem aços ao carbono e aços liga.

Os ferros fundidos têm acima de $2,11 \%$ de carbono até o limite de solubilidade de $6,7 \%$, porém os ferros fundidos comerciais contam, em geral com até $4,8 \%$ de carbono.

\section{APLICACÃO}

1) Cálculo envolvendo porcentagens de elementos de liga em aços

As porcentagens nos materiais siderúrgicos são em peso, por este motivo se fala num aço ou ferro fundido. Desta forma, quando se fala num aço com especificação americana da Society of Automotive Engineers (SAE), conhecida como SAE 1020, por se aplicar ao aço 1020 (com cerca de 0,20\% conteúdo de carbono em peso), que é definido na norma ABNT NBR 6006 (norma de classificação de aço para construção mecânica, por composição química. Esta norma é complementada pela NBR 9608 que é a norma destinada aos aços para construção). Um aço 1020 tem os seguintes valores aproximados de composição química (quadro 1).

Quadro 2 - Composição química do aço 1020

\begin{tabular}{c|c|c|c|c} 
Valores Referenciais & C & Mn & P máx & S máx \\
\hline Aço $1020-(\%)$ & $0,18-0,23$ & $0,30-0,60$ & 0,040 & 0,050 \\
\hline
\end{tabular}

Supondo que a porcentagem do carbono seja um valor médio da faixa da tabela 0,20\%, pergunta-se: em 100t de aço 1020, qual o peso de carbono existe inserido no mesmo?

\section{Resolução:}

Em 100 toneladas teremos $0,2 \mathrm{t}$ de carbono, ou seja, $200 \mathrm{Kg}$, que correspondem ao 0,2\% na tonelagem considerada.

2) Cálculo envolvendo composição de minério de ferro

Um lote de minério encomendado à mineradora por uma siderúrgica pede que o 
minério tenha $70 \%$ de hematita e $30 \%$ de magnetita. Pergunta-se: para 50t, quantos quilos de hematita estarão presentes?

\section{Resolução:}

Cada 100t de minério do lote conterá 70t de hematita e 30t de magnetita. Para 50t, tem-se a metade, ou seja, 35t de hematita e $15 t$ de magnetita. Logo, teremos 35t de hematita presentes.

3) Produção estimada de aço

Considerando-se a produção de aço do mês de julho de 2014 que foi de 19.678t. Caso todo mês se produzisse a mesma quantidade de aço (fato que não é real pois há vários fatores intervenientes, como é o caso do mês de fevereiro que tem menos dias e há meses em que há uma demanda sazonal maior ou menor), ao longo do ano de 2014, quanto se esperaria que fosse a produção prevista?

\section{Resolução:}

Considerando-se que um ano tem 12 meses e que no mês de julho a produção foi de 19.678t, desprezando-se os fatores de meses com menos dias, como é o caso do mês de fevereiro, e da questão da sazonalidade, teremos um cálculo simplificado (observe que pode não ser um cálculo real, mas somente teórico).

Peso ou tonelagem esperada para o ano de $2014=12$ x $19.678=236.136 \mathrm{t}$, ou seja, mais de duzentas mil de toneladas.

\section{CONSIDERAÇÕES FINAIS}

Finalizando o presente capítulo, observa-se as seguintes considerações:

_ O aço e os ferros contam com uma história de mais de 3.000 anos, considerando-se desde os primórdios até os dias atuais.

- Os produtos siderúrgicos são materiais importantes para os técnicos, tecnólogos, para engenharia e para a construção de máquinas e instalações. Além disso, o material mais reciclado do mundo, com quantidades superiores ao do alumínio e outros metais está nos produtos siderúrgicos.

_ O Brasil está entre os maiores produtores de produtos siderúrgicos do mundo.

_ Os cálculos em siderurgia são relativamente simples, em geral envolvendo regra de três, porcentagens de rendimento, porcentagens de conteúdo, peso e cálculos estequiométricos simples de reações químicas.

- Existem normas como é o caso da ABNT NBR 6006 que tratam da classificação dos aços.

\section{DICAS PARA OS ENGENHEIROS, TECNÓLOGOS, TÉCNICOS E PESSOAL DE OPERAÇÃO}

\footnotetext{
_ É importante que tenha em mente a questão da segurança, pois ferros e aço
} 
são produzidos à alta temperatura e seus respingos podem causar ferimentos. É preciso trabalhar em locais protegidos e seguros e com todos os Equipamentos de Proteção Individual (EPI) que possuam qualidade e resistência compatível com os riscos existentes em cada local de trabalho.

_ Outro aspecto importante é que o engenheiro, o tecnólogo ou técnico e os operadores têm que conhecer bem os processos, seus equipamentos e instalações, os procedimentos da sua área de trabalho, a forma correta de realizar o trabalho, a forma de obter produtividade e qualidade com segurança, as formas de ação para os casos de emergência, o trabalho conjunto em equipe sem falhas, os riscos que existem em suas áreas de trabalho e como lidar com eles, bem como possuam a sensibilidade em reconhecer as diferenças entre os materiais. Por exemplo, por meio da cor dos materiais, da cor e temperatura dos equipamentos, dos ruídos dos equipamentos é importante que se tenha uma ideia do que está acontecendo para prevenir dissabores.

_ Um exemplo de sensibilidade é: quanto mais carbono tem uma liga de ferro encostando no disco do esmeril em funcionamento, maior será a quantidade de faguIhas que surgem, com isso é possível ter uma ideia da qualidade do material que está sendo produzido.

\section{REFERÊNCIAS}

[1]. AÇO BRASIL. Estatísticas. (Antigo Instituto Brasileiro de Siderurgia - IBS). Publi- cado em agosto de 2014. Disponível em: <http://www.acobrasil.org.br/site/portugues/numeros/estatisticas.asp>. Acesso em: 27 ago. 2014.

[2]. BOFF, Leonardo. Sutentabilidade. Petrópolis: Vozes, 2012.

[3]. CHIAVERINI, Vicente. Aços e ferros fundidos. São Paulo: ABM, 2005.

[4]. COLPAERT, Humbertus. Metalografia dos produtos siderúrgicos comuns. São Paulo: Hemus, 2010.

[5]. COUTINHO, Eduardo; SHITSUKA, Ricardo. Avaliação das noções de sustentabilidade em três cursos de engenharia. Enciclopédia Biosfera, Centro Científico Conhecer - Goiânia, v.7, n.13; p. 1084-1092. 2011.

[6]. MENDES, José A. O ferro na história: das artes mecânicas às belas artes. Gestão e Desenvolvimento, n. 9, p. 301-318, 2000.

[7]. REUTERS. Produção mundial de aço bate recorde em 2013 impulsionada por China. Publicado no website Reuters Brasil em quinta-feira, 23 de janeiro de 2014 09:54 BRS. Disponível em: <http:// br.reuters.com/article/topNews/idBRSPEAOS3LD20140123>. Acesso em: 26 ago. 2014.

[8]. SACHS, I. Caminhos para o desenvolvimento sustentável. Rio de Janeiro: Garamond, 2000.

[9]. SILVA, José N. S. Siderurgia / José Nazareno Santos Silva - Belém: IFPA: Santa Maria: UFSM, 2011. 


\section{EXERCÍCIOS}

1. De onde vem o nome siderurgia e a que materiais se aplicam?

2. O que é um ferro fundido e o que é um aço?

3. Por que os aços são materiais importantes para a sociedade?

4. Numa mineradora de minério de ferro, o transporte do mesmo é realizado por meio de vagões ferroviários. Se cada vagão pode transportar em média 80t de minério, uma composição com 100 vagões transportará quantas toneladas de minério?

5. A usina está com um pedido de um lote de minério que tenha $60 \%$ de hematita, $30 \%$ de magnetita e $10 \%$ de óxido de ferro II. Esse conjunto deve ser misturado e enviado em contêineres de 100 t. Pergunta-se: Para se obter a composição mencionada de minério, cada contêiner deve ter quantas toneladas de oxido de ferro III, quantas de oxido de oxido de ferro II e III, e quantas de oxido de ferro II.

6. Uma indústria de tintas precisa de pigmentos da cor vermelha e pede que você indique o nome do pigmento obtido na indústria siderúrgica. Qual minério você recomendaria?

7. Quando o técnico recebeu uma amostra de material metálico, verificou-se que era material magnético para o imã e supôs que era uma liga de ferro. Os clientes perguntam insistentemente, qual o tipo de aço é aquele. Colocando a amostra no esmeril, verificou que veio uma quanti- dade muito grande de fagulhas o que indicava uma quantidade grande de carbono. A análise química qualitativa por espectrometria, que foi feita rapidamente, revelou que o material continha $3 \%$ de C, $1 \%$ de Si, $<1 \%$ de $\mathrm{Mn}$ e $<0,2 \%$ de S. Diante das informações, pergunta-se que tipo de aço é o mesmo?

8. Considerando-se um aço SAE 1045, para uma quantidade de $100 \mathrm{t}$ de aço, quantos quilos de carbono estão contidos no mesmo?

9. Num aço inox com $20 \%$ de cromo e $10 \%$ de níquel, pergunta-se qual o peso do cromo e níquel juntos em cada 100t deste aço?

10. O aço é um material 100\% reciclável. Se tivermos $30 t$ de latas de aço, quantas toneladas podemos reciclar? 


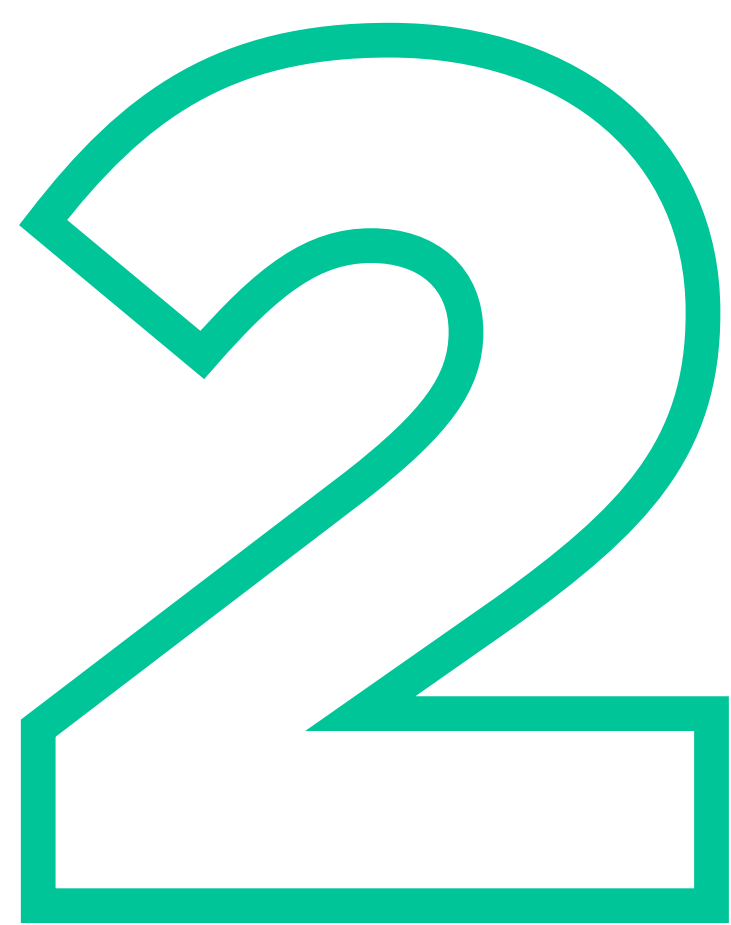

\section{PRODUTOS DE AÇO, MERCADO E PROPRIEDADES}

\section{Fala sobre:}

_ Introdução

_ Desenvolvimento

_ Tipos de produtos

_ Dicas sobre os produtos

- Qualidade

- Produtividade

- Custo

- Pós Venda

_ Dicas sobre segurança

_ Referências Bibliográficas

_ Exercícios resolvidos 


\section{INTRODUÇÃO}

O aço é um produto de extrema importância na dinâmica da atividade humana, assumindo papel determinante no funcionamento da economia, sobretudo por figurar como um elemento essencial para o perfeito encadeamento de diversas cadeias produtivas. É um produto indispensável para o desenvolvimento econômico dos países.

Existe, no mercado, um número muito grande de formas e tipos de produtos de aço. A grande variedade dos aços disponíveis no mercado deve-se ao fato de que cada uma de suas aplicações demanda alterações na sua composição e forma dos produtos a serem empregados para fabricação de instalações, equipamentos, máquinas e peças.

No que diz respeito à sustentabilidade, o setor siderúrgico aderiu aos princípios e valores do desenvolvimento sustentável, buscando sempre o uso mais racional dos recursos naturais e insumos, além de adotar tecnologias que permitam reduzir seus impactos sobre o meio ambiente. O aço é um produto totalmente reciclável e movimenta a economia em todos os seus estágios.

O setor da construção civil é um dos principais setores da economia brasileira, gerando renda e emprego para a população. Como esse setor, o comércio de produtos de aço para construção civil apresenta uma intensa relação com o desenvolvimento do país por ser um dos principais insumos.

\section{DESENVOLVIMENTO}

Os aços diferenciam-se entre si pela forma, tamanho e uniformidade dos grãos que o compõem e, é claro, por sua composição química. Esta pode ser alterada em função do interesse de sua aplicação final, obtendo-se, através da adição de determinados elementos químicos, aços com diferentes graus de resistência mecânica, soldabilidade, ductilidade, resistência à corrosão, entre outros.

De maneira geral, os aços possuem excelentes propriedades mecânicas, resistem bem à tração, à compressão e à flexão. Como é um material homogêneo, pode ser laminado, forjado, estampado, trefilado e estirado. Suas propriedades podem ainda ser modificadas por tratamentos térmicos ou químicos.

As propriedades do aço são de fundamental importância, especificamente no campo de estruturas metálicas, cujo projeto e execução nelas se baseiam. Tal relevância não é exclusiva dos aços, mas, de forma semelhante, aplica-se a todos os metais. Um exemplo da aplicabilidade das propriedades do aço é o teste de resistência: ao submeter uma barra metálica a um esforço de tração crescente, ela irá apresentar uma deformação progressiva de extensão, ou seja, um aumento de comprimento.

As características dos aços podem ser avaliadas pelas propriedades a seguir:

A elasticidade é a propriedade do metal de retornar à forma original, uma vez remo- 
vida a força externa atuante. Deste modo, a deformação segue a Lei de Hooke, sendo proporcional ao esforço aplicado:

$$
\mathbf{T}=\mu, \mathbf{E}
$$

onde:

$\mathrm{T}=$ tensão aplicada

$\mu=$ deformação

$\mathrm{E}=$ módulo de elasticidade do material módulo de Young.

O maior valor de tensão, para o qual vale a Lei de Hooke, denomina-se limite de proporcionalidade. Ao ultrapassar este limite, surge a fase plástica, em que ocorrem deformações crescentes, mesmo sem a variação da tensão. Esse processo é o denominado patamar de escoamento.

Alguns materiais - como o ferro fundido ou o aço liga tratado termicamente - não deformam plasticamente antes da ruptura, sendo considerados materiais frágeis (isto é, que quebram de modo semelhante ao vidro, sem se deformarem antes da quebra). Estes materiais não apresentam o patamar de escoamento.

A plasticidade é a propriedade inversa à da elasticidade, ou seja, o material não volta à sua forma inicial após a remoção da carga externa, obtendo-se deformações permanentes. A deformação plástica altera a estrutura de um metal, aumentando sua dureza. Este fenômeno é denominado endurecimento pela deformação a frio ou "encruamento".

A ductilidade é a capacidade do material de se deformar sob a ação de cargas antes de se romper. Essa propriedade é de grande importância, visto que tais deformações constituem um aviso prévio à ruptura final do material, o que previne acidentes em uma construção, por exemplo.

Por fim, temos a dureza, que é a resistência ao risco ou abrasão, ou seja, a resistência que a superfície do material oferece à penetração de um material dotado de maior dureza. Sua análise é de fundamental importância nas operações de estampagem de chapas de aços.

\section{FATORES QUE AFETAM AS PROPRIEDADES MECÂNICAS DO AÇO}

Os principais fatores que afetam os valores medidos das propriedades mecânicas são: a composição química, o histórico termomecânico do material, a geometria e a temperatura.

Dentre esses fatores, o mais importante na determinação das propriedades de um certo tipo de aço é a composição química.

Nos aços carbono comuns, os elementos carbono e manganês têm influência no controle da resistência, ductilidade e na facilidade de passar pelo processo de soldagem, ou seja, a soldabilidade.

O carbono aumenta a dureza e a resistência, mas, por outro lado, afeta a ductilidade e a soldabilidade. Assim, pequenas quantidades de outros elementos de liga são adicionados ao aço com a finalidade de melhoria das propriedades do material, obtendo 
o máximo em propriedades de uma liga contendo um baixo teor de carbono.

O histórico termomecânico do aço inclui a carga de deformação no laminador (que leva à redução da seção), velocidade de resfriamento e das temperaturas de acabamento do processo de laminação a quente. Estas variáveis influenciam profundamente as propriedades mecânicas dos aços.

\section{TIPOS DE AÇOS E PRODUTOS}

Quanto ao tipo, existe um número muito grande de formas e tipos de produtos de aço. A grande variedade dos aços disponíveis no mercado deve-se ao fato de cada uma de suas aplicações demandar alterações em sua composição e na sua forma.

Emrelaçãoà composição química, ao processamento, controles e ensaios (visando atender especificações dos clientes), além de sua utilização final, os aços podem ser classificados da seguinte forma:

1) Aços carbono

São aços ao carbono, ou com baixo teor de liga, de composição química definida em faixas amplas.

\section{2) Aços ligados/especiais}

São aços ligados ou de alto carbono, de composição química definida em estreitas faixas para todos os elementos e especificações rígidas.
3) Aços para construção mecânica

São aços ao carbono e de baixa liga para forjaria, rolamentos, molas, eixos, peças usinadas, dentre outros.

4) Aços ferramenta

São aços de alto carbono ou de alta liga, destinados à fabricação de ferramentas e matrizes para trabalho a quente e a frio, inclusive aços rápidos.

Quanto à forma geométrica, os aços podem ser classificados nas seguintes categorias:

1) Semi-acabados

São produtos oriundos de processo de lingotamento contínuo ou de laminação de desbaste, destinados a posterior processamento de laminação ou forjamento a quente. São eles: placas, blocos, tarugos.

\section{2) Produtos Planos}

São produtos siderúrgicos, resultado de processo de laminação, cuja largura é extremamente superior a espessura ( $L$ >>>E) e são comercializados na forma de chapas e bobinas de aços carbono e especiais.

\section{3) Não-revestidos}

Bobinas e chapas grossas do laminador de tiras a quente $(5 \mathrm{~mm}<\mathrm{E}>12,7 \mathrm{~mm})$; bobinas e chapas grossas do laminador de chapas grossas ( $\mathrm{E}>12,7 \mathrm{~mm}$ ); bobinas e chapas finas laminadas a quente (BQ/ (FQ); bobinas e chapas finas laminadas a frio (BF/CFF). 
4) Revestidos

Bobinas e chapas finas revestidas; folhas metálicas, revestidas, para embalagem (folhas estanhadas e folhas cromadas); bobinas e chapas eletro-galvanizadas (EG - Electrolytic Galvanized); bobinas e chapas zincadas a quente (HDG - Hot Dipped Galvanized); bobinas e chapas de ligas alumínio-zinco; bobinas e chapas pré-pintadas.

\section{5) Aço elétrico}

Bobinas e chapas em aços ao silício (chapas elétricas).

6) Aço inoxidável

Bobinas e chapas em aços inoxidáveis; bobinas e chapas em aços ao alto carbono ( $C>=0,50 \%$ ) e em outros aços ligados.

\section{7) Produtos Longos}

São produtos siderúrgicos, resultado de processo de laminação, cujas seções transversais têm formato poligonal e seu comprimento é extremamente superior à maior dimensão da seção, sendo ofertados em aços carbono e especiais.

Em aços carbono

Perfis leves ( $\mathrm{h}<80 \mathrm{~mm}$ ); perfis médios (80 $\mathrm{mm}<\mathrm{h}<=150 \mathrm{~mm}$ ); perfis pesados $(\mathrm{h}>150$ $\mathrm{mm}$ ); vergalhões; fio-máquina (principalmente para arames); barras (qualidade construção civil); tubos sem costura; trefilados.

Em aços ligados / especiais

Fio-máquina (para parafusos e outros); barras em aços construção mecânica; barras em aços ferramenta; barras em aços inoxidáveis e para válvulas; tubos sem costura; trefilados.

\section{APLICAÇÕES}

\section{1) Utilidades Domésticas}

O aço é empregado nos restaurantes, cozinhas industriais, hospitais, laboratórios, empresas em geral e nas casas das pessoas. Possuem a resistência necessária para os mais variados usos em forma de utensílios domésticos. Entre as propriedades do aço estão a resistência a baixas e altas temperaturas, superfície que evita o acúmulo de resíduos, composição química que o impede descascar, longa durabilidade e baixo custo de manutenção.

\section{2) Transporte}

O aço está presente nos carros, caminhões, ônibus, trens, metrôs, navios, bicicletas e motocicletas. Dessa forma, afirma-se que o aço transporta a população, interliga cidades e conduz as cargas, distribuindo riquezas e espalhando progresso.

\section{3) Construção civil}

Largamente usado na construção civil, o aço pode estar presente como parte das obras ou como material principal.

O sistema construtivo em aço permite liberdade no projeto de arquitetura, maior área útil, flexibilidade, compatibilidade com outros materiais, menor prazo de execução, racionalização de materiais e mão-de-obra, alívio de carga nas fundações, garantia de qualidade, maior orga- 
nização nos canteiros de obras e precisão construtiva.

\section{4) Embalagens e recipientes}

As embalagens de aço são usadas pela indústria em geral, sendo importantes na conservação e transporte de alimentos, produtos químicos, agrícolas, tintas, gases de cozinha e industriais; são produtos feitos em aço baixo carbono, laminados e revestidos com estanho ou cromo metálico.

Especialmente em relação aos alimentos, o aço evita a contaminação, assegurando a sua qualidade. Além disso, é $100 \%$ reciclável.

\section{5) Energia}

O aço é usado em hidrelétricas, termelétricas e nucleares, torres de transmissão, transformadores, cabos elétricos, plataformas, tubulações, equipamentos de prospecção e extração de petróleo, assim como em perfuratrizes, esteiras e caçambas das minas de carvão. Pelos motivos expostos, o aço é, portanto, fundamental na produção e distribuição de energia no País.

\section{6) Agricultura}

A eficiência do setor agrícola está diretamente ligada ao consumo de aço. A terra é preparada com arados, semeada e cercada usando equipamentos que levam aço. Na hora da colheita, com as ceifadeiras e colheitadeiras, assim como na armazenagem em silos e graneleiros, o aço também está presente, permitindo que os alimentos cheguem ao mercado.

\section{DICAS PARA OS ENGENHEIROS, TECNÓLOGOS, TÉCNICOS E PESSOAL DE OPERAÇÃO}

Todo produto é fabricado para atender algum cliente. Esta é a razão de todo trabalho realizado e é quem paga pelos produtos e serviços. Clientes precisam ser bem atendidos em suas exigências de: quantidade de material, qualidade, preço, condições de entrega, condições de pagamento, pós-venda etc. A empresa e seus funcionários devem se organizar para alcançar os objetivos que garantirão a continuidade dos trabalhos, dos salários, da saúde, da vida e enfim da sustentabilidade.

\section{REFERÊNCIAS}

[1]. ASHBY, M. F.; JONES, D. R. H. Engineering materials: an introduction to their properties \& applications. London: Butterworth Heinemann, 2001.

[2]. CHIAVERINI, Vicente. Aços e ferros fundidos. São Paulo: ABM, 2005.

[3]. CHIAVERINI, Vicente. Tecnologia mecânica: estrutura e propriedades das ligas metálicas. São Paulo: McGraw-Hill, 1986.

[4]. PARANHUS FILHO, Moacyr. Gestão da produção industrial. Curitiba: IBPEX, 2007. 


\section{EXERCÍCIOS}

1. Através de quais processos pode-se alterar as propriedades mecânicas de um determinado aço?

2. Quais são os testes utilizados para medir a resistência mecânica dos aços?

3. Dê exemplos de pelo menos três produtos de aço revestido.

4. A família de aços rápidos está enquadrada em qual tipo de aço?

5. Quanto à forma geométrica, os aços podem ser classificados em quais categorias?

6. Comente sobre as embalagens de aço utilizadas na indústria.

7. Que relação pode existir entre a agricultura e a indústria do aço?

8. Que relação pode existir entre a indústria do aço e a energia?

9. Que relação pode existir entre a indústria do aço e a construção civil?

10. Que relação pode existir entre a indústria do aço e o transporte? 


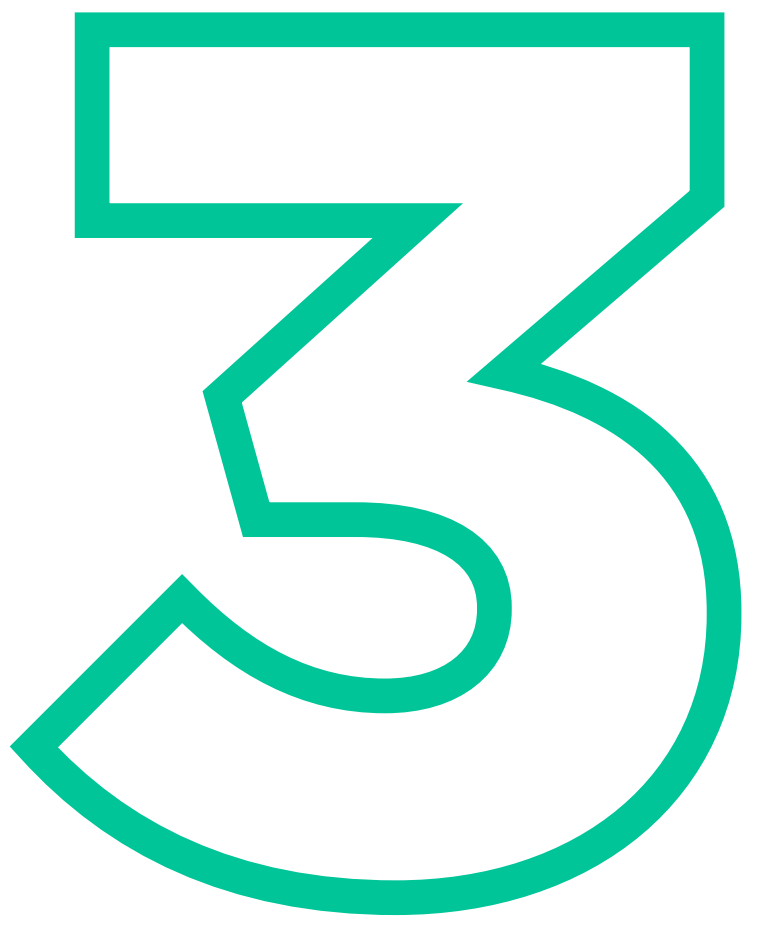

\section{PRODUTOS DE FERRO FUNDIDO, MERCADO E PROPRIEDADES}

\section{Fala sobre:}

_ Introdução

_ Desenvolvimento

_ Tipos de produtos

- Qualidade

- Preço

- Prazo de entrega

- Pós Venda

_ Principais variáveis no processo

_ Dicas sobre segurança

_ Referências Bibliográficas

_ Exercícios resolvidos 


\section{INTRODUÇÃO}

O ferro é um elemento químico abundante no Universo e no núcleo do Planeta Terra. Um ferro fundido é uma liga de ferro com composição próxima àquela do eutético ferro-carbono (COLPAERT, 2008).

Ferros fundidos são ligas de ferro que têm muita aplicação industrial. A maior parte das máquinas têm sua base e corpo fabricados em ferro fundido.

Os ferros fundidos são muito empregados na fabricação de componentes de máquinas e instalações. Em virtude de sua composição, eles quase não apresentam ductilidade (ou essa é muito pequena) e o material torna-se frágil de modo semeIhante ao vidro, que não se deforma e com tensões elevadas pode quebrar de vez em muitos pedaços.

Dutilidade é a propriedade do material que faz com que ele não se rompa de modo frágil, mas sim que absorva os impactos.

O objetivo do presente capítulo é apresentar alguns tipos de ferro fundido empregados no mercado e suas características.
Era preciso vencer a fragilidade em muitas aplicações e com essa finalidade, desenvolveu-se o tratamento térmico de maleabilização que faz com que um ferro fundido branco adquira um pouco de maleabilidade. Esse tratamento térmico ocorre em fornos com temperatura entre $900^{\circ} \mathrm{C}$ a $1000 \circ \mathrm{C}$ durante várias horas. O material passa pelos chamados "ciclos de maleabilização" nos quais se procuram obter estruturas de material mais dúteis (CHIAVERINI, 2008).

Para funcionar como base de máquinas, desenvolveu-se a forma de deposição de grafite no interior do ferro fundido que melhora a resistência ao impacto, criando-se os ferros fundidos cinzentos com veios de grafite. Para servir como blocos de motores autolubrificantes, criaram-se os ferros fundidos nodulares, que contêm nódulos de grafite que atuam como lubrificantes evitando o desgaste prematuro do material. Os tipos de ferro fundido (normalmente abrevia-se como "fofo").

A figura 1 apresenta um exemplo de lingotes de ferro fundido.

Figura 1 - apresenta um exemplo de lingotes de ferro fundido
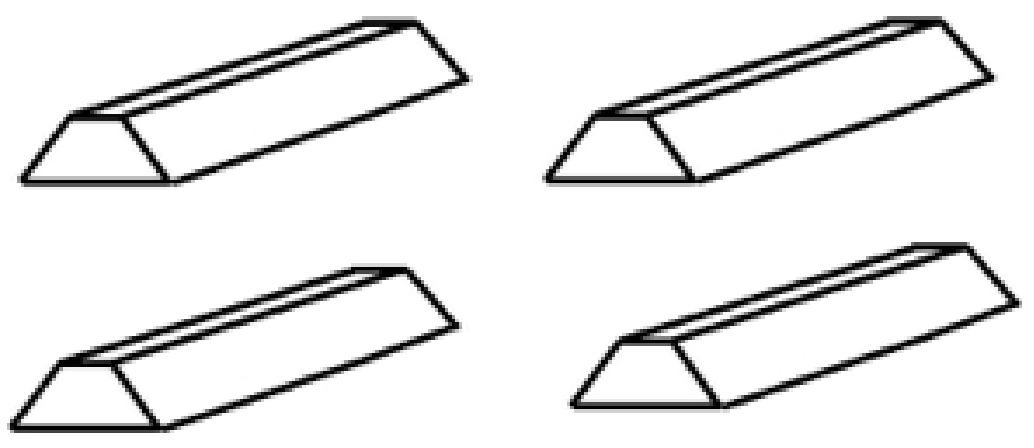

Fonte: autores 
Um lingote é uma forma de solidificação de um material metálico. Nesta forma ele pode ser armazenado, empilhado, transportado e refundido posteriormente para a fabricação das peças finais.

O aspecto da fratura dos ferros fundidos leva a sua denominação:

1) Ferro fundido cinzento - É um material cuja aparência na fratura de cor acinzentada; apresenta carbono livre na forma de grafite lamelar e parte de carbono combinado como carboneto de ferro (Fe3C).

2) Ferro fundido branco - Nesse material, a fratura apresenta uma cor clara e os elementos de liga fundamentais são o carbono e o silício. Na estrutura, por terem menor teor de silício, apresentam o carbono quase inteiramente na forma combinada com o carbono na forma de carboneto (Fe3C).

3) Ferro fundido maleável - É fabricado a partir do ferro fundido branco, por meio da aplicação de um tratamento térmico especial denominado "tratamento de maleabilização" que faz com que o material fique com a característica de boa dutibilidade, por isso a denominação de ferro fundido dúctil.

4) Ferro fundido nodular - Resulta de um tratamento que é realizado quando o material está em fabricação e ainda no estado líquido. O carbono livre vai se precipitar na forma de grafita esferoidal. Estes são os chamados "nódulos de grafita" e facilitam a lubrificação durante o uso, por exemplo, em blocos de motores.

O Quadro 2 apresenta a composição química de alguns dos tipos de ferro fundidos mais comuns.

Quadro 2 - ferros fundidos mais comuns

\begin{tabular}{ccccccc} 
& C & Si & Mn & S & P \\
Cinzento & $2,5-4,0$ & $1,0-3,0$ & $0,25-1,0$ & $0,02-0,25$ & $0,05-1,0$ \\
\hline Branco & $1,8-3,6$ & $0,5-1,9$ & $0,25-0,80$ & $0,06-0,20$ & $0,06-0,18$ \\
\hline Maleável & $2,0-2,6$ & $1,1-1,6$ & $0,20-1,0$ & $0,04-0,18$ & 0,18 máx. \\
\hline Dúctil & $3,0-4,0$ & $1,8-2,8$ & $0,10-1,0$ & 0,03 máx. & 0,10 máx. \\
\hline
\end{tabular}

No quadro 2 pode-se verificar que as composições dos ferros fundidos mais comuns, são diferentes conforme os respectivos tipos e associados às formas ou processos de fabricação. Em termos comparativos, pode-se alcançar as propriedades necessárias aos materiais.

A produção mundial de ferros fundidos tem aumentado e praticamente duplicou na última década (VILELA, 2010).

\section{APLICAÇ̃̃O}

Os ferros fundidos têm muita aplicação em válvulas, engrenagens, buchas, flanges, luvas, cotovelos e vários componentes mecânicos.

Muitas vezes, há substituição de peças de aço ou alumínio por peças de ferro fundido com vantagens de custos.

Em geral, os ferros fundidos têm pontos de fusão bem menores que os aços, o 
que leva a economia de energia na fabricação. Muitos possuem mais resistência ao desgaste e peso menor que os aços, outros possuem mais usinabilidade, facilidade para serem torneados, furados, frezados etc., de modo a facilitar a fabricação de peças com uso deste tipo de material.
Os ferros fundidos são materiais muitos empregados nas indústrias para a fabricação de peças diversas.

A figura 2 apresenta exemplos ilustrativos de aplicação de peças fabricadas em ferro fundido.

Figura 2 - exemplos ilustrativos de aplicação de peças fabricadas em ferro fundido
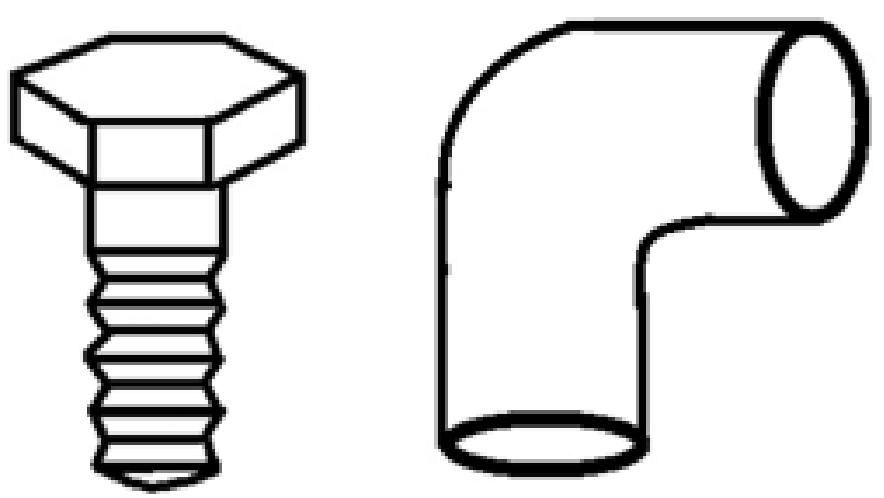

Fonte: autores

\section{CONSIDERAÇÕES FINAIS}

A indústria de ferros é uma das mais prósperas, pois a sociedade necessita de materiais que atendam aos seus requisitos de durabilidade, conformabilidade, dureza, resistência, beleza, custo etc. Nestes quesitos, os ferros fundidos, dependendo do seu tipo, podem atender a uma gama grande de produtos, conforme critérios exigidos, e por este motivo esses materiais continuam sendo muito empregados. É comum se encontrar novas aplicações para os materiais. No contexto mencionado, as siderúrgicas que produzem os materiais de ferro fundido têm um destaque em nível mundial.

Os portugueses trouxeram para o Brasil a fundição de ferro a partir do século VII.
Durante certo período, as oficinas de reparo das ferrovias e os estaleiros navais tinham as oficinas metalúrgicas mais equipadas do país (BETHELL, 2002).

As ligas de ferro podem ser: aço ou ferros fundidos, enquanto que os ferros fundidos podem ser: branco, mesclado, cinzento, nodular, vermicular e maleável.

\section{DICAS PARA OS} ENGENHEIROS, TECNÓLOGOS, TÉCNICOS E PESSOAL DE OPERAÇÃO

- Os ferros fundidos podem ser fabricados em fornos elétricos, de queima de óleo, a gás ou até mesmo nos fornos tipo cubilot, que recebem carga de sucata de aço e carvão. As propriedades do aço, que variam com o teor de carbono não 
se aplicam no caso dos ferros fundidos. Desta forma, mesmo que varie o teor de carbono, não variará a propriedade mecânica da ductilidade. Enquanto os aços se fundem à temperaturas em geral acima de $1550^{\circ} \mathrm{C}$ (no caso dos ferros fundidos), a maioria se funde a temperaturas em torno de $1300^{\circ} \mathrm{C}$ e, desta forma, é possível se ter alguma economia de energia.

_ Normalmente, a indústria utiliza muitas peças de ferro fundidas nas máquinas e a fabricação ocorre nas fundições. Um exemplo disso ocorre na base das máquinas, que geralmente é de ferro fundido. Nas fábricas de autopeças também há um grande emprego desse tipo de material.

\section{Observação}

O eutético é uma palavra que se aplica às ligas metálicas e se refere especificamente, à liga que para uma determinada composição química tem o menor ponto de fusão, ou seja, a menor temperatura na qual a liga se derrete.

\section{REFERÊNCIAS}

[1]. BETHELL, Leslie. História da América Latina. vol. 5: de 1870 a 1930. Trad. de Geraldo Gerson de Souza. São Paulo: Edusp; Imprensa Oficial de SP; Brasília, DF: Funag, 2002.

[2]. CANALE, Laurice. Ferros fundidos. Disponível em: <http://disciplinas.stoa. usp.br/pluginfile.php/91152/mod_ resource/content/1/Aula_6_FERROS\%20
FUNDIDOS2.pdf>. Acesso em: 16 jan. 2015.

[3]. CHIAVERINI, Vicente. Aços e ferros fundidos: características gerais, tratamentos térmicos, principais tipos. 7.ed. São Paulo: Associação Brasileira de Metalurgia e Materiais, 2008.

[4]. COLPAERT, Humbertus. Metalografia dos produtos siderúrgicos comuns. 4.ed. São Paulo: Edgard Blucher, 2008.

[5]. VILELA, Fernando J. Efeito de algumas variáveis de processo na obtenção do ferro fundido nodular ferrítico no estado bruto de fundição. Dissertação (Mestrado) CEUN, EEN, 2010.

\section{BIBLIOGRAFIA CONSULTADA}

TUPY. Perguntas frequentes sobre o fofo. Disponível em: <http://www.tupy.com.br/ imagens/promocional /folders/PerguntasMaisFrequentesSobreFUCO.pdf>. Acesso em: 16 jan. 2015. 


\section{EXERCÍCIOS}

1. Um técnico recebeu um lote de milhares de peças fabricadas recentemente. $O$ material foi identificado como sendo um ferro fundido. A análise química revelou a seguinte composição química: 4\% C, 3\% Si, $1 \% \mathrm{Mn}, 0,25 \% \mathrm{~S}$ e $1,0 \%$ P. Qual seria o tipo de ferro fundido recomendado?

2. Um operador de forno de uma fundição vai ligar um forno para fundir ferro fundido e pede que você especifique a temperatura que ele deve regular o forno para que fique horas em aquecimento e quando alcançar a temperatura possa se fundir. Pergunta-se, considerando-se 50 graus centígrados acima da temperatura de fusão comum para um ferro fundido que será vazado imediatamente em moldes de areia, qual seria a temperatura recomendada?

3. O que é um forno cubilot? Qual a sua carga? Onde é utilizado?

4. O material ferro fundido que resulta de um tratamento que é realizado quando o material está em fabricação e ainda no estado líquido, no qual o carbono livre vai se precipitar na forma de grafita esferoidal é bastante empregado em aplicações que se necessita de autolubrificação. Este é o caso dos blocos de motores que podiam funcionar durante anos, rodando centenas de milhares de quilômetros sem necessitar de retífica. Como é denominado este tipo de ferro fundido que contém, disperso no seu interior, as pequenas bolinhas de grafita?

5. Existe um tratamento térmico especial no qual, a partir do ferro fundido branco, se faz com que o material fique com a característica de boa ductibilidade. A denominação frequente para esse material é ferro fundido dúctil. Que tratamento térmico é realizado neste ferro fundido branco?

6. Muitos diagramas de ligas metálicas apresentam pontos nos gráficos de temperatura em função da composição química, onde existe a menor temperatura de fusão. Em outras palavras, o conceito se aplica às ligas metálicas e se refere especificamente à liga que para uma determinada composição química tem o menor ponto de fusão, ou seja, a menor temperatura na qual a liga se derrete. Como se denomina o conceito em foco referente a essa menor temperatura de ponto de fusão?

7. Os ferros fundidos são ligas metálicas que contêm principalmente ferro e carbono. Nestas ligas, qual a faixa de teor de carbono em porcentagem normal?

8. Qual processo de fabricação seria a melhor indicação para um ferro fundido cinzento?

9. Um motor de veículo feito em bloco de alumínio teria uma duração de uso menor que aquela que pode ter quando na sua parte interna entram os pistões. Eles são revestidos por camisas de material especial e os pistões recebem anéis de material também especial. Assim, ocorrerá o deslizamento destes anéis no interior das camisas. Qual é o melhor material para os anéis de segmento?

10. Uma máquina pesada e grande, como é o caso de uma fresa, de um torno ou 
mesmo de uma máquina de estampagem, tem que ter um corpo que absorva as oscilações e impactos. Geralmente estes corpos de máquina são fabricados num material barato, que seja de fácil fabricação e tenha as propriedades para resistir às condições mencionadas. Qual é o material mais indicado para fazer a base ou corpo desse tipo de máquina? 


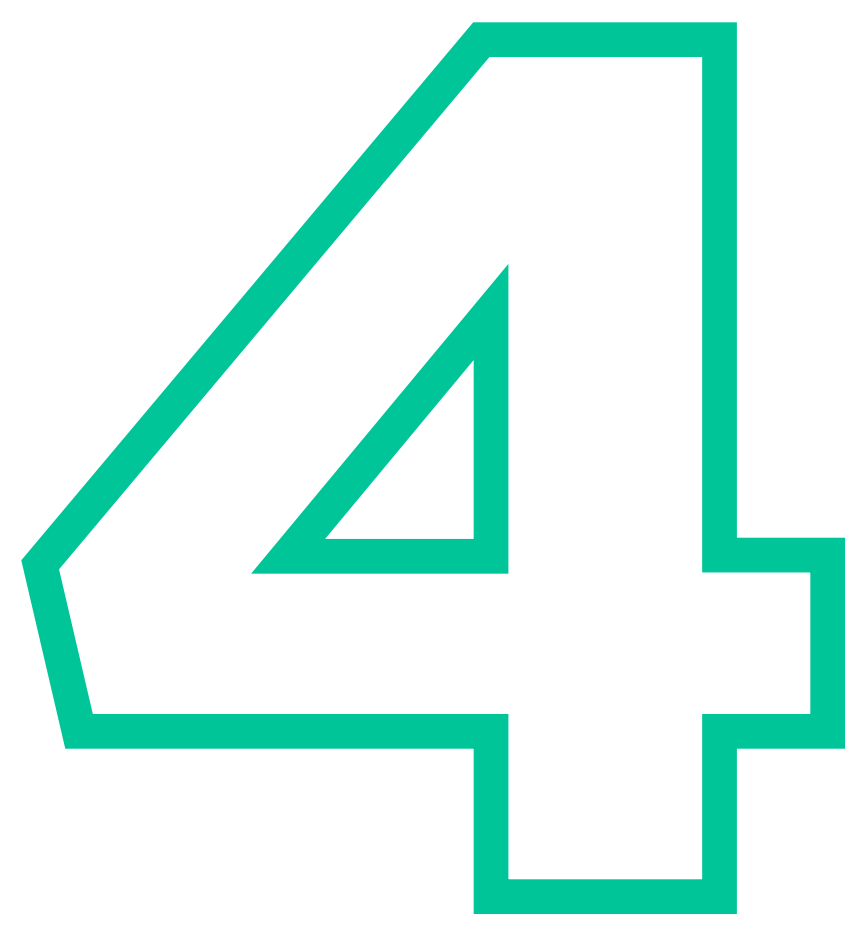

\section{PROCESSOS}

SIDERÚRGICOS A PARTIR DE REDUÇÃO DIRETA DE MINÉRIO

\section{Fala sobre:}

_ Introdução

_ Aplicação

_ Desenvolvimento

_ Processos de redução direta

_ Dicas sobre produtos

- Qualidade

- Produtividade

- Custo

- Pós Venda

_ Dicas sobre segurança

_ Referências Bibliográficas

_ Exercícios resolvidos 


\section{INTRODUÇÃO}

A redução direta de minério de ferro é uma forma de obter o ferro a partir do contato direto do minério com o gás CO (monóxido de carbono), que é extremamente redutor. Esse processo é feito em fornos reatores, em temperaturas não tão elevadas quando aquelas dos altos-fornos (que funciona em processo contínuo de carregamento de minérios, redução e, periodicamente, há o vazamento da corrida pela parte inferior do forno) e a produção é bem menor no caso dos processos de redução direta, por não se tratar de processo contínuo.

A produção de "ferro esponja" (ferro contendo porosidade), por processos mais econômicos, ocorre na redução direta, na qual não há fusão na obtenção do ferro. Este será utilizado posteriormente, por exemplo, na fusão em fornos elétricos para fabricação de aços ou de outros produtos e ocorrerá um gasto maior da energia elétrica. Desta forma, pode-se ter processos mais "limpos", com menos efeitos ambientais que nos processos contínuos de produção de gusa líquido em altos-fornos (AF).

O objetivo deste capítulo é apresentar a redução direta, os processos e equipamentos relacionados com tal prática, discutindo vantagens e desvantagens.

Os processos de redução direta de minério de ferro têm o objetivo de obter ferro a partir do minério (principalmente hematita e magnetita). Eles ocorrem em temperaturas elevadas, porém menores que a da região das "ventaneiras" dos altos-fornos. Desta forma, nesses processos, não ocorre fusão do material processado. Existem dois processos distintos: a redução direta e a indireta do minério de ferro (SILVA, 2010).

A fabricação de ferro tem, nos processos de redução direta e indireta, formas de economizar energia térmica e trabalhar quantidades menores de material em relação aos processos de alto-forno. Nos processos, inicialmente faz-se a produção do gás monóxido de carbono (CO), que é um gás muito reativo e que tem avidez por oxigênio. A seguir, ocorre a reação do gás com o minério promovendo a redução.

\section{PROCESSOS DE REDUÇÃO DIRETA MAIS CONHECIDOS}

Processos são conjuntos de atividades trabalhos que visam a algum tipo de transformação. Entre processos de redução direta mais utilizados estão: Midrex, SL-RN, HyL (Hayata y Lâmina) do México, e Purofer e Tecnored.

Os processos Midrex (canadense) e HyL (mexicano) fazem a redução em forno reator vertical onde, a partir da mistura do gás redutor, que entra pela parte inferior do forno e sai em uma região mais elevada, a carga é realizada pelo topo. O leito de resfriamento se localiza na parte inferior. O tempo de permanência da carga de pelota, ou minério, é de $6 \mathrm{~h}$. A reação de redução ocorre no forno reator, numa faixa em torno de $7600 \mathrm{o}$ (INFOMET, 2015). As temperaturas de redução são 
bem menores que aquelas encontradas nos altos-fornos. Para a produção do gás redutor, é necessário que exista uma instalação, onde se realizará uma mistura de carvão com vapor de água.

Segundo Noldin Júnior (2002), o Tecnored é um processo brasileiro, que tem como principal inventor o engenheiro Marcos de Albuquerque Contrucci, ex-professor do DCMM /PUC-RJ. O processo funciona com pelotas autorredutoras. O forno é baixo, vertical, compacto e de baixo custo. Possui cuba central superior, na qual se carregam as pelotas. Há uma carga lateral de carvão e o sopro de ar na região inferior (de modo semelhante a um alto-forno de dimensões muito reduzidas), por onde também sai o produto de gusa. Além da queima de carvão, pode-se usar outros combustíveis sólidos como é o caso de biomassas. O equipamento pode ser usado para fundir sucata ou gusa a um custo muito baixo (Ibid). Esse processo é de baixo custo porque não têm partes móveis, sendo uma excelente via de produção de metal líquido, por exemplo, para abastecer aciarias de modo mais econômico que as aciarias elétricas.

O processo Fastmet é um processo rápido, que reduz pelotas com altíssima velocidade, entre 6 a 12 minutos. As pelotas são produzidas a partir de materiais finos de minério e carvão. Ele é uma produção conjunta das empresas Midrex e Kobe Steel, que, a partir da década de 90 , passaram a possuir alguns equipamentos e instalações funcionando com a tecnologia. A carga é feita por sistema vibratório. Há queimadores de gás natural (Ibid). O sistema funciona a alta velocidade.
No caso do processo SL/RN, utiliza-se um forno rotativo com um grau de inclinação para que a carga caminhe no forno. A produção de ferro esponja ocorre por meio de reações entre o minério e o gás em contracorrente no forno. Em relação aos processos de redução direta de minério de ferro, afirma-se que estes respondem por cerca de $26 \%$ da produção total por redução direta no mundo (ERWIN; PISTÓRIUS, 2012).

Trata-se de um processo importante que funciona em vários países do mundo, como é o caso da Índia, África do Sul e Brasil. Neste, há uma instalação na Fábrica de Aços Piratini, que fica no Município de Charqueadas, no Estado do Rio Grande do Sul.

\section{EQUIPAMENTOS PARA REDUÇÃO DIRETA}

Os equipamentos de redução direta, normalmente, são fornos reatores de baixa altura, fechados. Eles possuem dispositivos para realizar o carregamento e descarregamento de minério de ferro e contam com injeção de gás redutor, que é o CO. Nesses equipamentos, há algum meio de aquecimento para se alcançar a temperatura de redução, que é por volta de $760^{\circ} \mathrm{C}$ a $800^{\circ} \mathrm{C}$. Em relação aos altos-fornos, são fornos para baixa produção. Podem contar com filtros para recuperação de subprodutos, como é o caso do zinco.

\section{VANTAGENS E DESVANTAGENS}

Como vantagens, há o menor investimento 
em relação aos altos-fornos, economia de energia em relação à produção de ferro gusa, facilidade de se adaptar às mudanças mundiais, o que não ocorre em equipamentos de alta produção. Na produção por redução direta de minério de ferro podem-se aproveitar os finos de minério.

As desvantagens estão na baixa produtividade e produção quando se necessitam de muito ferro.

\section{DICAS PARA OS ENGENHEIROS, TECNÓLOGOS, TÉCNICOS E PESSOAL DE OPERAÇÃO}

- Os processos de redução direta são complexos, envolvem gases, como é o caso do $\mathrm{CO}$, que é gás tóxico ao ser humano, mas é produzido, por exemplo, em todos os motores de combustão interna à gasolina dos veículos automotores. Esses processos possuem muitas instalações, muitos equipamentos e sistemas de controle, conforme a escala de produção seja maior. Tais equipamentos devem estar com manutenção rigorosamente em dia e em boas condições de operação. É interessante que o pessoal envolvido diretamente conheça os equipamentos, seu funcionamento, seus riscos e a forma correta de operar e lidar com os riscos, tanto para si quanto para seus colegas e equipe, lembrando que a segurança sempre vem em primeiro lugar.

\section{REFERÊNCIAS}

[1]. ERWEE, Markus W.; PISTORIUS, P.C. Nitrogen in SL/RN direct reduced iron: origin and effect on nitrogen control in EAF steelmaking. Publshed in 2012. Retrieved from: <http://repository.up.ac. za/bitstream/ handle/2263/20077/Erwee_ Nitrogen(2012).pdf?sequence $=1>$. Access on: July, 21, 2015

[2]. KEMPKA, Anderson. Auto-redução do ferro-esponja: uma nova técnica para o aumento de sua qualidade. Dissertação (Mestrado) Centro de Tecnologia da Escola de Engenharia da UFRGS, 2008.

[3]. NOLDIN Junior, José H. Contribuição ao estudo da cinética de redução de briquetes auto-redutores Puc-Rio. Tese (Doutorado). PPG em Engenharia Metalúrgica da Pontifícia Universidade Católica do Rio de Janeiro, 2002.

[4]. SILVA, André C. Simulação computacional da redução direta de minério de ferro em fornos MIDREX. Tese (Doutorado) Programa de Pós-Graduação em Engenharia de Materiais da REDEMAT, 2010. 


\section{EXERCÍCIOS}

1. Comente a frase: "nos processos de redução direta de minério de ferro, o carvão é o agente redutor direto por meio do seu carbono".

2. Muitos países têm trabalhado no desenvolvimento conjunto de processos de redução direta. Qual é o nome do processo que é realizado em conjunto entre o México e o Japão para redução direta mencionado nesta obra?

3. Comente a frase: "os processos de redução direta de minério de ferro ocorrem em temperaturas maiores que as do alto-forno".

4. O processo de produção de ferro gusa, a partir de redução de minério de ferro, é desenvolvido no Brasil. Ele conta com um forno baixo, vertical, compacto, de baixo custo e que funciona com pelotas autorredutoras; possui cuba central superior, na qual se carregam as pelotas. Como se denomina esse processo?

5. Os processos de redução direta são demorados e gastam horas para realizar a redução com exceção do processo FASMET, que é um processo rápido e reduz pelotas com altíssima velocidade. Qual a faixa de tempo gasta essa redução nesse processo?

6. Em relação ao gás utilizado nos processos de redução direta de minério de ferro, qual é esse gás e como ele afeta a saúde humana?

7. Os processos de redução direta de minério de ferro são processos que permitem trabalhar com os finos dos minérios. Cite pelo menos três características desses processos.

8. Cite três afirmações corretas em relação aos processos de redução direta.

9. Cite três vantagens dos processos de redução direta de minério de ferro e uma desvantagem.

10. Como se denomina o processo de redução direta canadense mencionado nesta obra? 


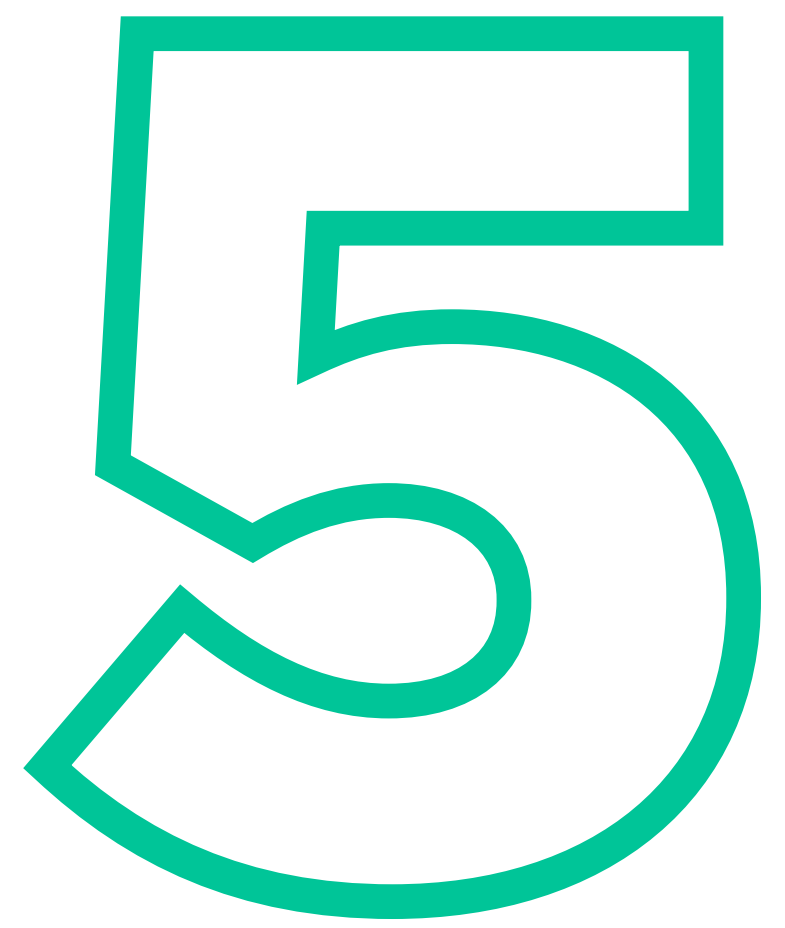

\section{PRINCIPAIS EQUIPAMENTOS SIDERÚRGICOS}

\section{Fala sobre:}

_ Introdução

_ Desenvolvimento

_ Aplicação

_ Normas sobre segurança

_ Dicas sobre segurança

_ Referências Bibliográficas

_ Exercícios resolvidos 


\section{INTRODUÇÃO}

Este capítulo apresenta, por meio de imagens, os principais equipamentos siderúrgicos utilizados desde o processo de mineração, como por exemplo: pás carregadeiras de minério, caminhões, empilhadeiras, Jigs, moinhos, britadores, vagões ferroviários, silos de minério, altos-fornos, panelas de gusa, carros torpedos, pontes rolantes, calha de sucata, convertedor LD, panela de aço, desgaseificador, panela de escória, distribuidor de lingotamento contínuo, lingotamento contínuo, corte, laminação e outros.

A obra contém os principais equipamentos, onde pode-se destacar os destinados aos seguintes processos: movimentação, processamento mineral, equipamentos de alto forno, aciaria, lingotamento continuo e convencional, laminação a quente e a frio e equipamentos dos processos de revestimentos.

Neste capítulo serão tratados somente os equipamentos de movimentação, de processamento mineral, aciaria e lingotamento. Os demais serão tratados nos respectivos capítulos.

\section{EQUIPAMENTOS DE MOVIMENTAÇÃO}

Nas organizações, sempre existem fluxos de materiais, informações e pessoas. Em relação às siderúrgicas, torna-se interessante que os materiais sejam movimentados com segurança, menor custo, tempo e com garantia de qualidade, seguindo as normas aplicáveis, sejam elas internacionais, nacionais ou internas às empresas.

Apresenta-se, a seguir, alguns equipamentos, ou seja, os mais usuais, de movimentação de materiais utilizados na siderurgia integrada.

A escavadeira é um equipamento muito utilizado nos processos de escavação, formação de pilhas, carregamento de minérios, principalmente, nos caminhões e movimentação de minérios na siderurgia de um modo geral.

A figura 3 é um exemplo ilustrativo e simplificado de uma escavadeira.

Figura 3 - representação esquemática de uma escavadeira

Fonte: autores

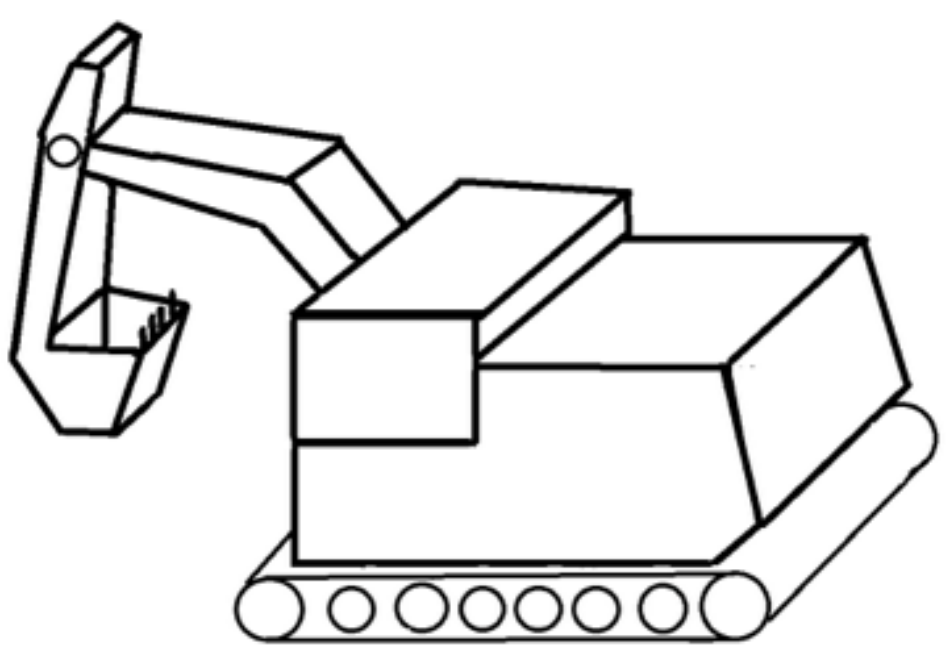


Tecnologia siderúrgica

A pá carregadeira é um pequeno trator utilizado para movimentação de materiais, principalmente sucatas geradas nos processos siderúrgicos.

A figura 4 é um exemplo esquemático de uma pá carregadeira.

Figura 4 - representação esquemática de uma pá carregadeira

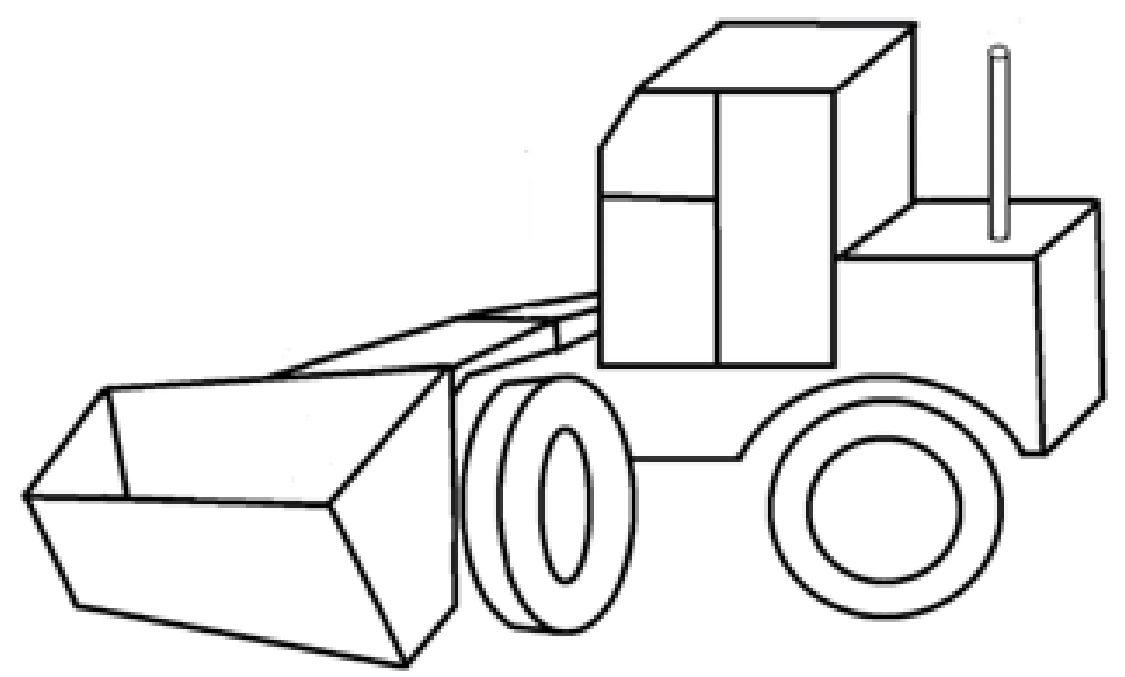

Fonte: autores

Figura 5 - representação esquemática de uma empilhadeira

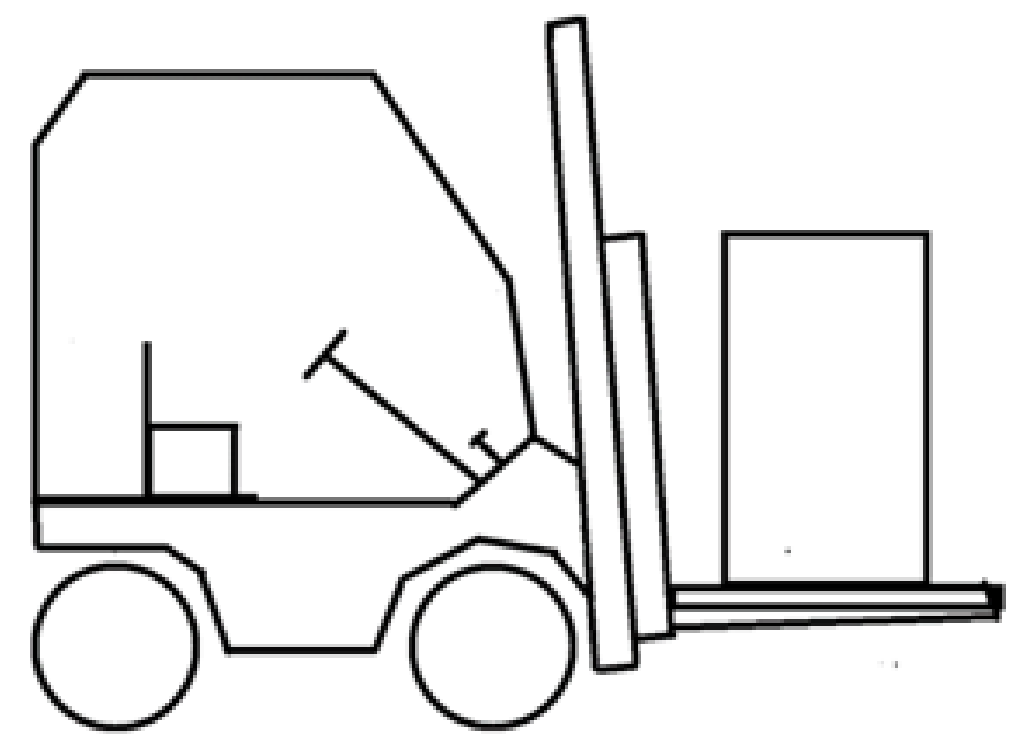

Fonte: autores 
O pórtico é uma ponte rolante de céu aberto, ou seja, é um equipamento utilizado em locais onde é dispensado coberturas de galpão.
A figura 6 é uma representação esquemática de um pórtico. Na figura, destacam-se as principais partes: os trilhos e as garras.

Figura 6 - representação esquemática de um pórtico (ponte rolante de céu aberto)

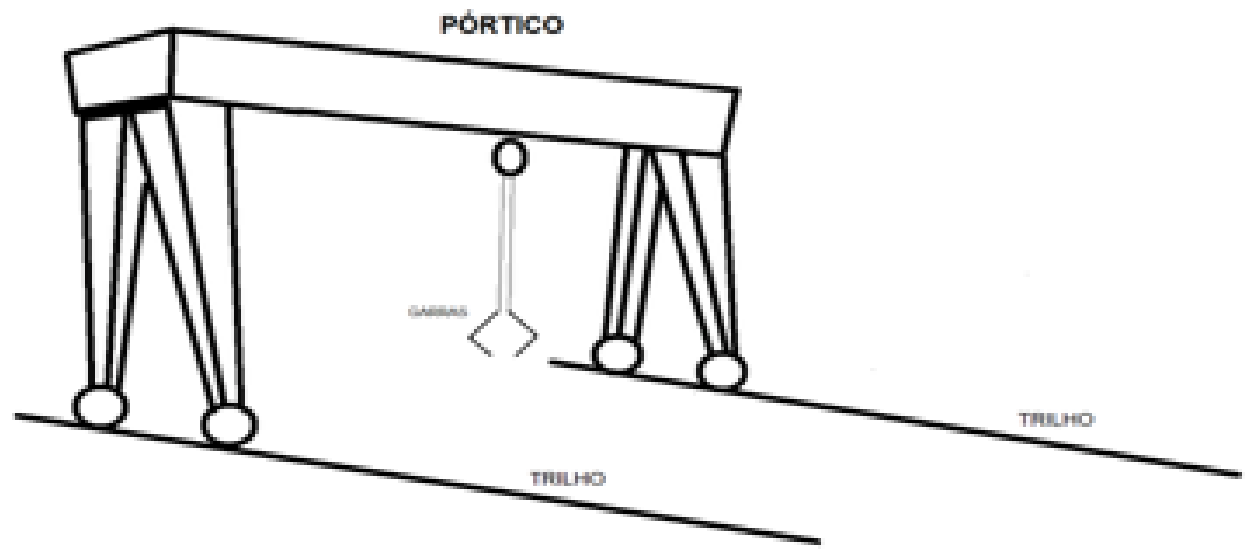

Fonte: autores

A correia transportadora e caminhão para transporte de minério são equipamentos para transporte de minério em esteira com roletes e cinta de borracha.

A figura 7 é um exemplo de uma esteira transportadora fazendo carregamento num caminhão posicionado no final da correia. Na figura, pode-se visualizar as partes principais, tais como: o silo, a correia transportadora e o caminhão basculante posicionado no local da carga.

Figura 7 - representação esquemática de uma correia transportadora para transporte de minério

Fonte: autores

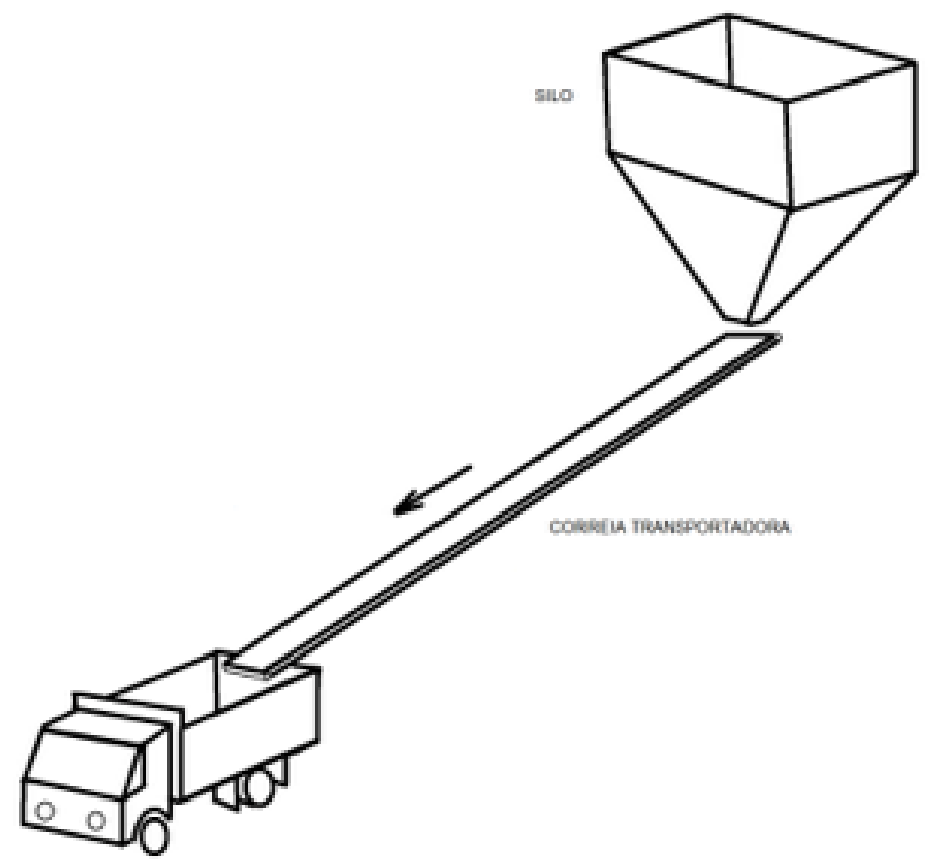


EQUIPAMENTOS DE PROCESSAMENTO MINERAL

Além da movimentação, há os processos industriais que têm como objetivo algum tipo de transformação de matérias-primas em produtos. Um produto de um processo pode ser matéria prima de outro processo seguinte. Processos agregam valor aos produtos e deste modo, um produto, em princípio, deve valer mais que a matéria prima. Os processos ocorrem em estações ou paradas nas quais existem equi- pamentos para realizar as transformações necessárias. Nos itens seguintes, apresentam-se alguns equipamentos utilizados em processos ligados à indústria de processamento mineral e também à siderurgia.

O britador de mandíbulas é um equipamento usado para reduzir o tamanho do minério bruto.

A figura 8 é uma representação esquemática de um britador de mandíbulas típico. $\mathrm{Na}$ figura, pode-se visualizar as partes principais do britador, tais como: volante, mandíbula e carcaça.

Figura 8 - é uma representação esquemática de um britador de mandíbulas típico

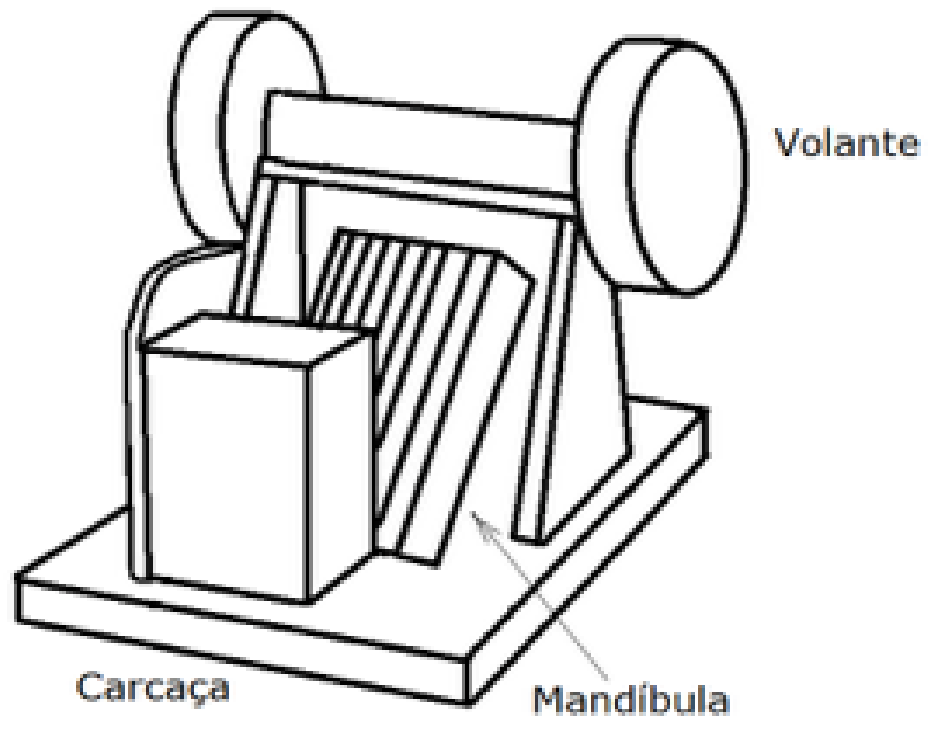

Fonte: autores

Outro equipamento que vale citar, é o moinho. Ele também é utilizado para propiciar uma redução no tamanho da matéria prima. Sua constituição é formada, basicamente, por um tambor de aço giratório, contendo as referidas bolas de aço, com diferentes diâmetros, junto com a matéria prima a ser processada.

\section{EQUIPAMENTOS DE ALTO-FORNO (AF)}

O alto-forno é equipamento no qual ocorre a transformação do minério de ferro em ferro gusa que é um material com alto teor de carbono e silício. Depois da adição dos elementos de liga, esses equipamentos 
funcionam continuamente durante vados, que é o aço, com custos relativaanos, evidentemente, com manutenção adequada. Vale destacar que, mesmo quando estiverem em manutenção, estes equipamentos não podem parar completamente sua produção. Sua produtividade é altíssima e com isso pode-se fabricar produtos a base de ferro ou seus derimente baixos.

A panela de gusa é um equipamento destinado ao transporte da matéria prima gusa líquida.

A figura 9 apresenta uma visão esquemática de uma panela de gusa.

Figura 9 - visão esquemática de uma panela de gusa

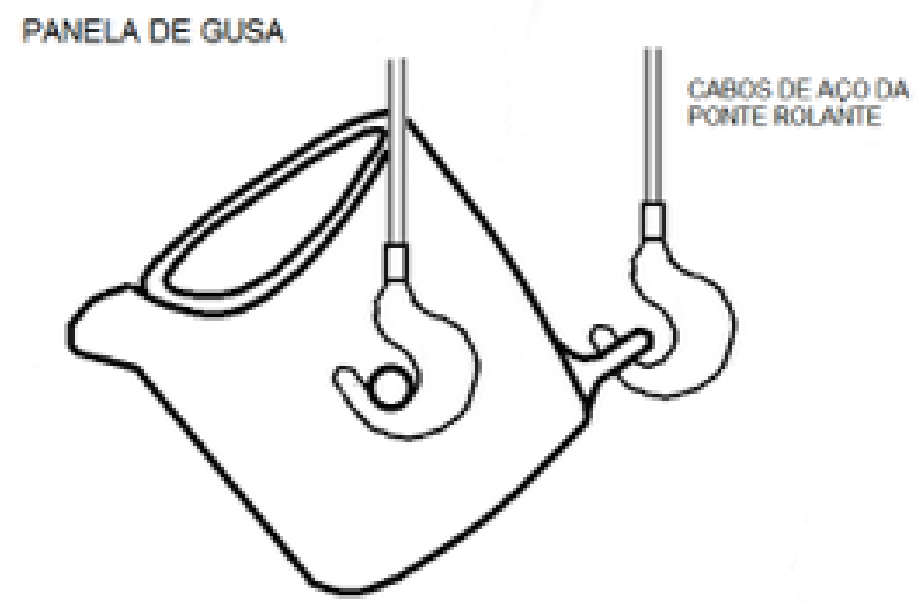

Fonte: autores

O carro torpedo é um equipamento para A figura 10 apresenta uma visão esquemáarmazenamento e transporte do gusa liquido. tica de um carro torpedo típico.

Figura 10 - visão esquemática de um carro torpedo típico

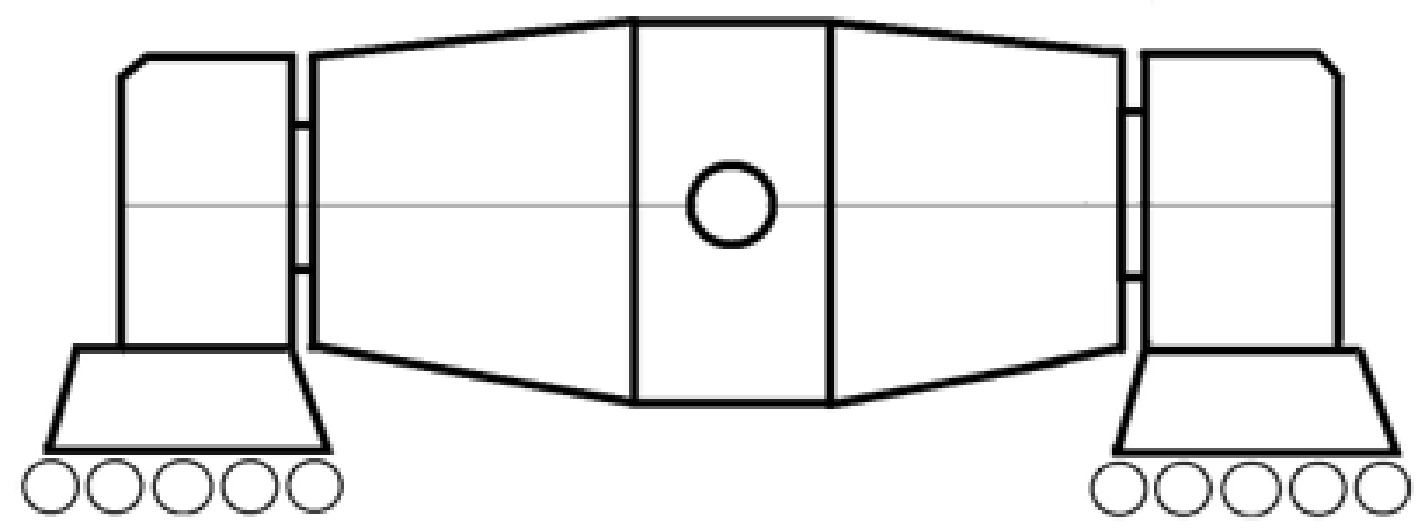

Fonte: autores 


\section{EQUIPAMENTOS DE ACIARIA}

A aciaria é o local, ou estação, na qual se realiza o processo de fabricação de aço; é onde se faz a adequação da composição química.

Nas siderúrgicas integradas, ocorre a conversão do gusa em aço, por meio do sopro de oxigênio e adição de certos elementos de liga.

Considerando as fábricas semi-integradas, esta conversão ocorre durante fusão de sucata de aço, normalmente, em fornos elétricos.

A lança de oxigênio é um equipamento destinado a fabricação de aço, a partir de gusa e sucata, nas aciarias de alta produção, ou seja, corridas com, aproximadamente, 250 toneladas.

A figura 11 apresenta uma visão esquemática de um conversor LD com a lança de oxigênio puro posicionada.

Figura 11 - visão esquemática de um conversor LD com a lança de oxigênio puro posicionada no momento do sopro

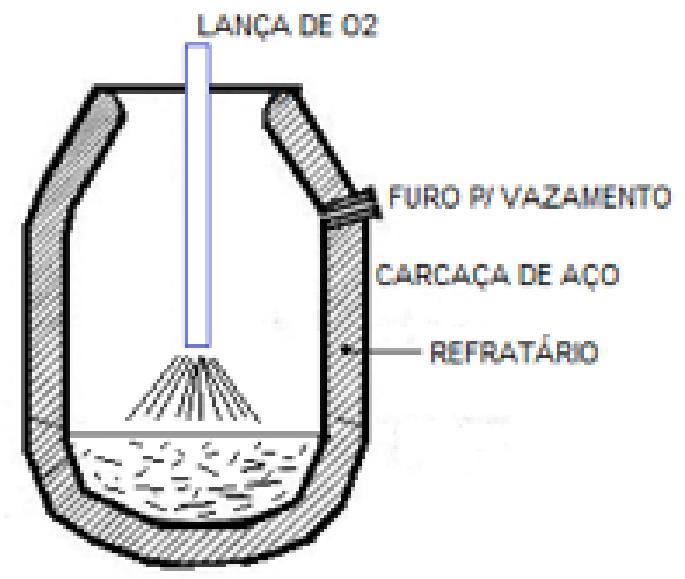

Fonte: autores

\section{EQUIPAMENTOS DE LINGOTAMENTO}

O molde de lingotamento contínuo é um equipamento destinado a solidificar e dar forma ao aço líquido.

A instalação de um equipamento de lingotamento contínuo propicia às industrias alta produtividade na solidificação do aço líquido.
A figura 12 apresenta uma visão esquemática de um equipamento de lingotamento continuo. 
Figura 12 -visão esquemática de um equipamento de lingotamento continuo

Fonte: autores

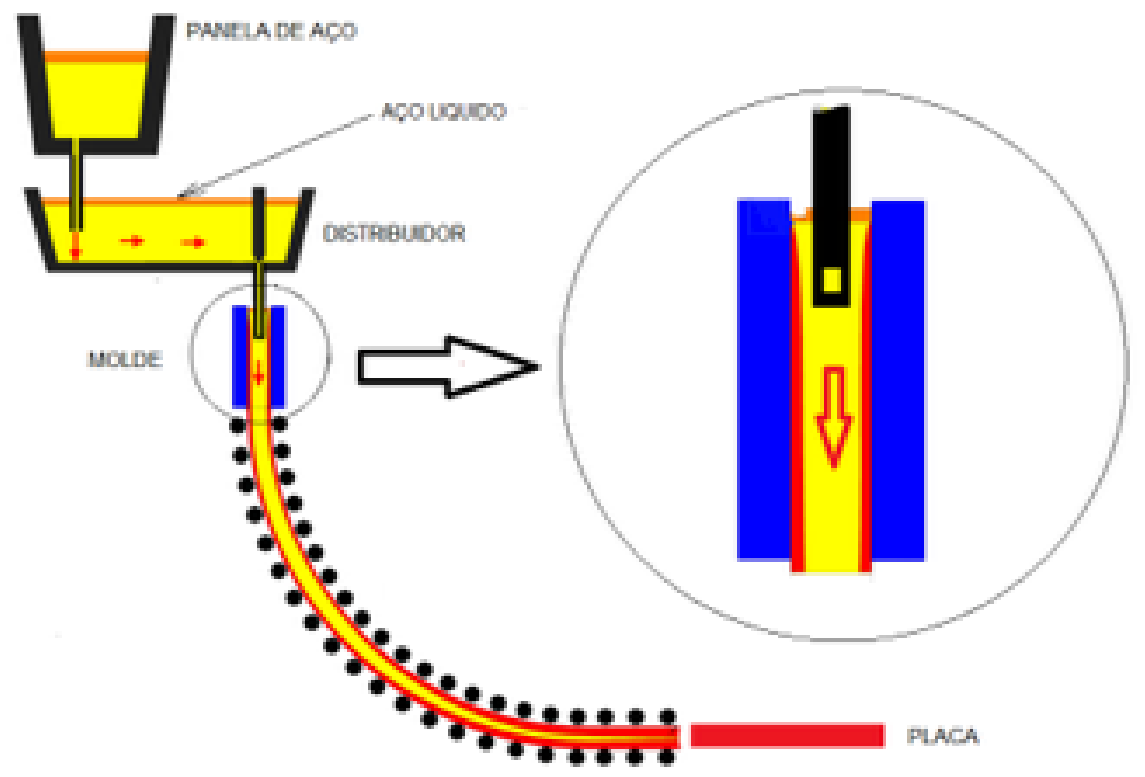

\section{DICAS PARA OS} ENGENHEIROS, TECNÓLOGOS, TÉCNICOS E PESSOAL DE OPERAÇÃO

_ Todo equipamento representa um investimento realizado. Cada máquina tem obsolescência, necessidade de manutenção e ela tem que se pagar, ou seja, pelo trabalho com a máquina deve-se gerar riquezas de forma que se possa fazer frente aos custos, gerar salários tanto para ela quanto para outros processos, pois alguém precisa vender os produtos, alguém precisa programar a produção, alguém precisa adquirir peças e alguém precisa trabaIhar com a contabilidade. É preciso ajudar a gerar o salário de todos. É preciso estar atento para que ocorra a operação correta dos equipamentos e que eles sejam conservados com boa manutenção para funcionar bem, garantindo qualidade e segurança, tanto de pessoal quanto de equipamentos.

\section{BIBLIOGRAFIA CONSULTADA}

[1]. ARAÚJO, Luis A. Siderurgia. v.1 e 2. São Paulo: Arte e Ciência, 2009. 
Tecnología siderúrgica

\section{EXERCÍCIOS}

1. Cite três equipamentos utilizados na movimentação de materiais na mineração de ferro.

2. Cite três equipamentos de processamento mineral.

3. Cite três equipamentos da região do alto forno.

4. Cite três equipamentos de movimentação na aciaria integrada.

5. Cite três equipamentos da aciaria e lingotamento.

6. Cite três equipamentos da laminação.

7. Cite três instalações de acabamento.

8. Descreva as principais partes de um forno elétrico a arco.

9. Descreva as principais partes da instalação de um forno convertedor LD.

10. Descreva as principais partes da instalação de um lingotamento contínuo. 


\section{PROCESSOS DE ALTO-FORNO}

\section{Fala sobre:}

_. Introdução

_ Partes de um alto forno

_ O produto gusa

_ Dicas sobre o processo

_ Dicas sobre segurança

_ Referências Bibliográficas

_. Exercícios resolvidos 


\section{INTRODUÇÃO}

Alto-forno (AF) é um forno de grande altura, no qual a carga de matérias-primas é feita pela região superior e o produto, que é o ferro gusa, sai pela região inferior do forno. O processo acontece em contracorrente de material, isto é, de baixo para cima, sobre o ar que é injetado para reagir com o carvão e formar o gás CO que vai reagir com o minério de ferro fazendo o processo de redução.

O objetivo do presente capítulo é apresentar o alto-forno como uma máquina, ou reator químico, de alta produtividade de produção de gusa, que é um ferro que vem sujo ou com muita contaminação de silício, carbono, fósforo e outros elementos químicos. Esse equipamento é essencial para o trabalho em grande escala de produção. Porém, gusa não é o produto final e sim o aço. Por este motivo, ele terá que passar por outros processos de limpeza, ou refino, que vão fazer com que o produto final (aço) tenha as propriedades mecânicas necessárias à fabricação de peças e instalações.
Os AFs são reatores químicos verticais, que são carregados pela parte superior com minério de ferro, carvão e fundentes. Nesses vasos ocorrem as reações de redução do minério de ferro na presença de carvão coque, que se transforma em gás $\mathrm{CO}$ e $\mathrm{CO} 2$. O minério de ferro reage com o gás CO à alta temperatura, liberando o ferro que pelo peso, desce até a região inferior do cadinho.

Em outras palavras, pode-se dizer que alto-forno é um reator que funciona na vertical; recebe uma carga de minério, carvão e fundentes pela parte superior do forno. A saída do produto gerado, que é o gusa, é feito pela parte inferior do forno.

\section{PARTES PRINCIPAIS DE UM ALTO-FORNO}

Um alto-forno é composto por algumas partes principais (topo, ventaneiras e a esteira de alimentação). A figura 13 apresenta uma visão esquemática de um alto forno mostrando suas partes principais.

Figura 13 - visão esquemática de um alto forno mostrando suas partes principais

Fonte: autores

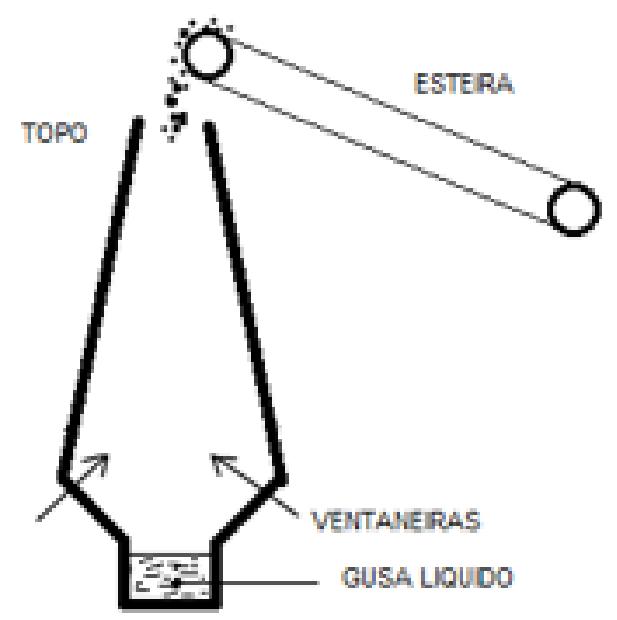


Com relação a temperatura, ele varia ao longo de sua altura. A figura 14 apresenta a variação de temperatura ao longo da altura do forno.

Figura 14 - variação da temperatura ao longo da altura do alto forno

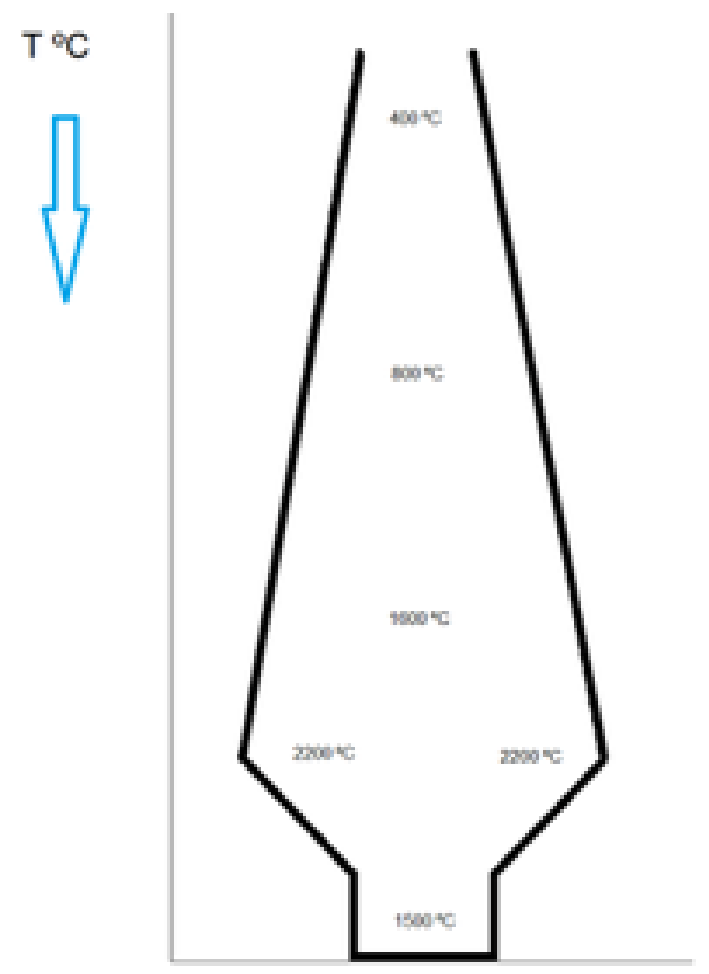

Fonte: autores

A região superior é a do topo do alto-forno e acima dela há o sino de alimentação (sino invertido). Esta é uma região na qual a pressão é elevada e saem muitos gases do processo à alta temperatura.

A região da goela é a parte superior da cuba. Nesta região, a carga vai reagindo e descendo.

A região do ventre é a de maior diâmetro no forno. Logo a seguir, há um estreitamento, que corresponde à região da rampa cuja finalidade é segurar a carga.

Na região inferior da rampa, há ventaneiras. Estas são sopradores por onde entra o ar que vai reagir para formar o gás $\mathrm{CO}$, que vai atuar como redutor da carga de minério de ferro.
A região do cadinho (região inferior) é por onde desce o ferro gusa produzido nas reações de redução do minério, que ocorreram nas regiões anteriores. Como o ferro tem densidade maior, ele vai para o fundo, ou seja, a região do cadinho.

Um alto-forno é um equipamento de alta produtividade; demora vários dias para aquecer até chegar à temperatura de trabalho e começar a ser carregado. A partir dessa operação, o carregamento é continuado, bem como o sopro e o forno funcionam $24 \mathrm{~h}$ por dia e 365 dias por ano.

Os reparos no forno, mesmo dos refratários internos, geralmente são feitos com o equipamento operando. Normalmente, em 
volta da carcaça do forno há uma camisa d'água cuja finalidade é resfriar a carcaça.

O instrumental de medição deve funcionar continuadamente e fornecer as informações, para que ocorram as alterações nos processos e que permitam o forno funcionar com os parâmetros, dentro dos limites e com boa produtividade.

\section{MECANISMO DE OPERAÇÃO DO ALTO FORNO}

O alto-forno é um equipamento térmico de altíssima produtividade. Como ele funciona direto após iniciar seu funcionamento, torna-se interessante saber como é o seu início de operação. O aquecimento do forno, antes de começar a carga, é feito por meio de queimadores, que ficam durante dias queimando e aquecendo os refratários internos do forno. Este aquecimento gradativo e lento é realizado de forma a possibilitar que os refratários mudem de fase conforme se alcancem patamares de temperatura adequados. Com a mudança de fase, o refratário passa por outras densidades e alterações volumétricas. Quando o refratário alcança uma temperatura, na qual possa ocorrer o início da carga, começa-se o carregamento do carvão e das matérias-primas e o início da operação que ocorrerá durante anos.

\section{DICAS PARA OS ENGENHEIROS, TECNÓLOGOS, TÉCNICOS E PESSOAL DE OPERAÇÃO}

- Há várias pessoas que trabalham num AF direta ou indiretamente. Um exemplo direto é constituído pelas equipes, operadores e pessoal de manutenção que trabaIham em turno, revezando-se durante $24 \mathrm{~h}$ por dia e 365 dias por ano. Há também as pessoas que trabalham não na linha de frente, por exemplo, nas instalações de produção de oxigênio para uso no processo de sopro do alto forno e também na aciaria LD.

_ As instalações de oxigênio são importantíssimas e normalmente ficam a certa distância do AF e da aciaria, sendo o oxigênio transportado por meio de linhas de tubulações, que são especialmente projetadas, construídas, verificadas e utilizadas para tal finalidade. A título de exemplo, um dos aspectos importantes dessas linhas, é que antes do seu uso se faça uma limpeza interna do tipo flushing com outro gás de arraste, para que não deixe poeiras ou pós de metais, que ao ser arrastado possa gerar fagulhas e consequentemente, explosão.

_ Outro pessoal que trabalha indiretamente é aquele que vai fazer o tratamento de água que vai ser utilizado, por exemplo, para resfriamento na camisa de água da carcaça. Também trabalham indiretamente o pessoal que faz a programação da produção e aquele encarregado em 
realizar a movimentação dos materiais.

_- É muito importante que todos trabalhem de modo coordenado e com boa comunicação para que não ocorram falhas.

\section{REFERÊNCIAS}

[1]: ANGELO, Marciano M. Construção e simulação de um algoritmo que permita prever a injeção de diferentes tipos de materiais pulverizados pelas ventaneiras em altos-fornos. Dissertação (Mestrado). Pós-Graduação em Engenharia de Materiais da REDEMAT. Disponível em: <http:// www.redemat.ufop.br/arquivos/disserta coes /2013/ConstrucaoSimulacao.pdf> Acesso em: 20 jul. 2015.

[2]. COLPAERT, Humbertus. Metalografia dos produtos siderúrgicos comuns. 4.ed. São Paulo: Edgard Blucher, 2008.

\section{BIBLIOGRAFIA CONSULTADA}

[1]. ARAÚJO, Luis A. Siderúrgia. São Paulo: Arte e Ciência, 2009. v.1 e 2.

\section{EXERCÍCIOS}

1. Em que região do $A F$ se localiza o cadinho?

2. Qual a região de maior temperatura no AF?

3. Em relação ao AF, a carga é feita em qual região? E a saída de gusa, ocorre em qual região? Qual a região que suporta a carga?

4. Cite três características em relação aos gases do AF.

5. Quando a carcaça externa de um AF começa se avermelhar em alguma região, o que pode indicar isso?

6. O monitoramento da temperatura da água de resfriamento da carcaça do AF pode servir para alguma coisa?

7. Nos altos-fornos muitos altos, em torno de 100 metros de altura, se faz a carga com carvão coque e não com carvão mineral. Por quê?

8. O que é processo de coqueificação no carvão coque? Por que esse processo é realizado?

9. Qual o objetivo em injetar ar pré-aquecido nas ventaneiras de um AF?

10. A gusa que sai do AF é muito rica em Silício. Qual teor comum desse elemento químico no banho da gusa? 


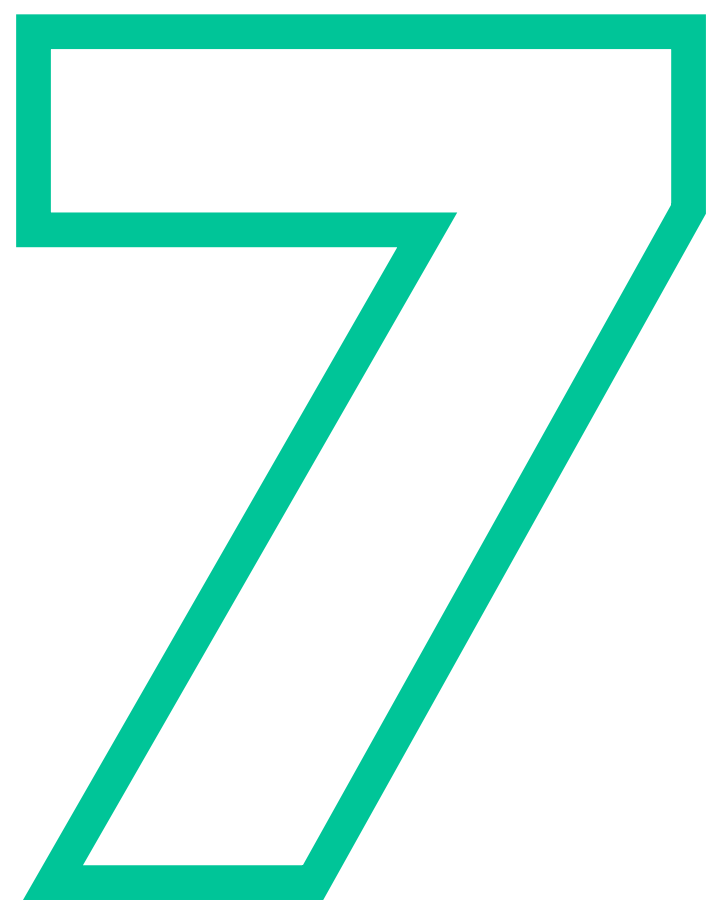

\section{PROCESSOS A PARTIR DE SUCATA DE AÇO}

\section{Fala sobre:}

_ Introdução

_ A fabricação de aço a partir da sucata

_ Aplicação

_ Separação magnética desucatas

_ Dicas sobre segurança

_ Referências Bibliográficas

_ Exercícios resolvidos 


\section{INTRODUÇÃO}

No Brasil, a exportação de aço é da ordem de $0,2 \%$ e a importação é de $0,1 \%$ do mercado mundial (GO ASSOCIADOS, 2013).

Apesar da quantidade relativamente pequena em termos mundiais, existem muitas siderúrgicas que são aquelas que trabalham com forno elétrico de fusão, que funcionam exclusivamente com sucatas e não com gusa proveniente dos altos-fornos.

No Brasil, estima-se que existam 29 siderúrgicas, sendo 13 integradas e 16 com fornos elétricos (CNI, 2010, 2012).

Atualmente, as siderúrgicas brasileiras possuem uma produção grande, porém o Brasil não está entre os cinco maiores produtores de aço mundial.

As sucatas de aço podem ser recicladas e reprocessadas, gerando novos materiais de aço quantas vezes forem necessárias, sem que o material perca suas propriedades. As fontes geradoras de sucata são: sucata de produção interna, sucata geração industrial, sucata de obsolescência e bens de capital sucateado (ANDRADE et al., 2000).

A grande geração de sucata é nas áreas industriais. A produção interna é comumente reaproveitada nos processos de fusão e fabricação do aço. Outras sucatas industriais são resultantes do descarte da produção interna das indústrias, provenientes do descarte de máquinas, equipamentos, peças e a sucata gerada pela produção de lingotes de gusa em pequenas fábricas de gusa.

Um dos aspectos que facilita o trabalho com a sucata advém do fato de que, em geral, ela é magnética e com isso, por meio de eletroímãs operados em pontes rolantes ou em outros equipamentos de movimentação, pode-se facilitar o manuseio e, por conseguinte, o transporte e reutilização deste material ferroso.

O objetivo do presente capítulo é falar sobre a sucata na fabricação de aço e suas vantagens em relação à fabricação por meio de minério de ferro.

\section{A FABRICAÇÃO DE AÇO A PARTIR DE SUCATA}

A fabricação de aço a partir de sucata ocorre principalmente nos fornos elétricos de fusão, "mini" siderúrgicas, que não funcionam com minério de ferro, como ocorre nas chamadas "siderúrgicas integradas". A matéria-prima delas é a própria sucata e não se emprega minério de ferro nestas fábricas. Não ocorre nelas o processo de redução (que corresponderia à remoção de oxigênio do minério de ferro).

Estima-se que a participação, para os anos em torno de 2010, é que a produção de aço proveniente de sucata em relação à de minério de ferro é cerca de $40 \%$ (ANDRADE, 2000).

Em relação à pureza do aço, aquele que é proveniente de processos de alto-forno é mais puro, ou seja, contém menos impureza que os provenientes de sucata, em que existe a mistura de material e muitos aços 
já contém elementos de liga, que vão entrar para o material resultante dos processos. No caso do material proveniente de sucatas, fica mais difícil o controle das contaminações que estão contidas na sucata.

A sucata pode conter impurezas de elementos químicos, que não são possíveis de se separar por processos tradicionais. A separação só pode ocorrer quando o metal ferro está fundido e uma das formas de se eliminar parte dos elementos químicos, que são impurezas (provenientes de sucatas de materiais com ligas), é por meio da formação de escórias, que vão sobrenadar o banho e podem absorver parte dos elementos indesejáveis, que está no banho líquido de aço.

Um aspecto interessante é que, mesmo nas siderúrgicas integradas, se faz a carga de cerca de $20 \%$ de sucata na aciaria, em conjunto com gusa que vem do alto-forno. Esta sucata, normalmente, é proveniente dos processos internos, por exemplo, dos cascões de sucata, que se formam nas panelas de aço e outros equipamentos siderúrgicos. Junto às sucatas mencionadas, também pode-se adicionar alguma quantidade de gusa na forma de lingotes (adquirido de fabricantes externos de gusa, os denominados "guseiros").

O cascão é formado nos equipamentos siderúrgicos quando estes não estão bem preaquecidos antes de serem utilizados. O preaquecimento é realizado por meio de maçaricos, que vão queimar gás no interior do equipamento durante horas, até que ele alcance a temperatura de uso.
Desta forma, aumenta-se a vida útil dos equipamentos utilizados na siderurgia e que são destinados à manipulação direta dos materiais líquidos à alta temperatura.

Já nas metalúrgicas que trabalham somente com sucata como matéria-prima, como é o caso de fundições de aço, que utilizam os fornos elétricos e a aquisição externa de sucata, há um consumo elevado de energia elétrica, mas estas fábricas podem ser de tamanho bem menor em relação às siderúrgicas integradas. No Brasil, a produção conjunta de fundições e usinas com fornos elétricos de fusão de sucata consome algo em torno de 500 mil toneladas anuais (CNI, 2010, 2012).

Em relação ao mercado mundial, o Brasil é um pequeno produtor de aço a partir de sucata, mas que tende a crescer em volume nos próximos anos à medida que houver a regulamentação das sucatas da indústria automobilística.

Pelo ponto de vista energético, o uso de sucata ferrosa como rota principal na produção de aço bruto proporciona uma significativa redução no consumo energético, em comparação as demais rotas. Em termos globais, a produção de aço pelas Usinas Integradas demanda cerca de três vezes mais energia que a produção pelas usinas semi-integradas, ou seja, aquelas que trabalham com sucata e forno elétrico (TRINDADE Jr., 2013).

Observa-se que há a possibilidade de redução no consumo energético, baixando, portanto, o custo de fabricação, a poluição e aumentando a sustentabilidade da siderurgia. 


\section{CONSIDERAÇÕES FINAIS}

O aço é de longe o material mais reciclado do planeta, pois ao ser reutilizado, conserva suas propriedades químicas. Talvez por esse motivo, as sucatas de aço sejam bem aproveitadas. Além disso, a seleção pode ser feita por meio das propriedades magnéticas, o que facilita a reciclagem desse material.

No Estado de São Paulo, 18\% da matéria-prima que movimenta a siderurgia (ramo da metalurgia relacionado aos produtos de ferro e aço) é sucata. A siderurgia representa cerca de $95 \%$ de toda metalurgia no Brasil (MANCINI, 2013).

O Brasil possui algumas regiões com maior concentração de minério de ferro, como é o caso dos Estados de Minas Gerais e Maranhão. Principalmente no primeiro, há uma grande quantidade de siderúrgicas integradas, que são as fábricas de aço, que funcionam a partir do minério de ferro. Por outro lado, há uma grande quantidade de indústrias e fundições, que funcionam à base da matéria-prima sucata em outros estados.

A participação da sucata na produção de aço brasileiro é em torno de até 30\% da produção (GO ASSOCIADOS, 2013).

A sucata é material barato e é proveniente muitas vezes dos descartes e ferros velhos. Quando eles são reciclados podem ser transformados em ferros fundidos, que são materiais muito utilizados nas indústrias em seus equipamentos e peças.

\section{DICAS PARA OS ENGENHEIROS, TECNÓLOGOS, TÉCNICOS E PESSOAL DE OPERAÇÃO}

- Sucata é um material barato e para os aços mais comuns ela pode ser separada por meios magnéticos, o que facilita sua recuperação; geralmente é obtida dos processos internos das indústrias e é complementada pela aquisição de material externo.

_ O pessoal que trabalha com este tipo de material e lida mais com a movimentação de grandes quantidade e pesos, tem que estar vacinado contra tétano e precisa trabalhar sempre seguindo as normas de trabalho da área.

_ Um cuidado importante na sucata que será utilizada na carga de um conversor LD é que essa sucata não pode conter umidade. Para tanto, quando há alguma suspeita de sucata que ficou no tempo (pegou chuva) e umidade, umas das ações é passar o maçarico, durante alguns minutos, em cima da sucata para se eliminar qualquer umidade.

\section{REFERÊNCIAS}

[1]. ANDRADE, Maria L. A. et al. Mercado mundial de sucata. Publicado no website do BNDES em 2000. Disponível em: <http:// www.bndes.gov.br/SiteBNDES/export/ sites/default/bndes_pt/Galerias/Arquivos/ conhecimento/relato/sucata.pdf $>$. Acesso em: 14 mar. 2015.

[2]. GO ASSOCIADOS. Estudo sobre o 
setor de sucata de ferro e o impacto da adoção de impostos sobre a exportação de sucata ferrosa no Brasil. Elaborado pela equipe da GO Associados. 23/01/2013. Disponível em: <http://sindinesfa.org.br/ download/diversos/O_Mercado_Ferroso_ Brasileiro.pdf>. Acesso em: 14 mar. 2015.

[3]. CNI - Confederação Nacional da Indústria. Sucata e a indústria brasileira do aço. Instituto Aço Brasil, 2010. Disponível em: <http://www2.camara.leg.br/ atividade-legislativa/comissoes/comissoes-permanentes/cdeic/ apresentacoes-e-arquivos-audiencias-e-seminarios/Apres_ InstitutoAoBrasill.ppt>. Acesso em: 14 mar. 2015.

[4]. CNI - Confederação Nacional da Indústria. A indústria do aço no Brasil. Brasília: CNI, 2012. Disponível em: <http:// www.acobrasil.org.br/site/portugues/ sustentabilidade/downloads/livro_cni. pdf>. Acesso em: 14 mar. 2015.

[5]. MANCINI, Sandro D. As vantagens da sucata. Publicado em 26 nov. 2013. Disponível em: <http://www. cruzeirodosul.inf. br/materia/517142/as-vantagens-da-sucata>. Acesso em: 14 mar. 2015.

[6]. TRINDADE Jr. José Carlos Nogueira. Obtenção, mercado e reciclagem de sucatas ferrosas na indústria siderúrgica brasileira. Projeto de Graduação apresentado ao Departamento de Engenharia Metalúrgica e Materiais da Escola Politécnica, Universidade Federal do Rio de Janeiro, curso de Engenharia Metalúrgica, 2013. Disponível em: <http://monografias.poli.ufrj. br/monografias/monopoli10010007.pdf>.
Acesso em: 14 mar. 2015.

\section{BIBLIOGRAFIA CONSULTADA}

[1]. ARAÚjO, Luis A. Siderúrgia. v.1 e 2. São Paulo: Arte e Ciência, 2009. 


\section{EXERCÍCIOS}

1. Uma sucata de aço inoxidável não era atraída por eletroímã. Pode-se concluir que se trata de que tipo de material de sucata?

2. Qual o material metálico mais reciclado do mundo?

3. Qual material é mais puro, em termos de contaminantes: gusa de alto forno ou sucata de procedência externa?

4. No Brasil, quais são os estados com maior concentração de minério de ferro explorável?

5. A siderurgia faz uso da sucata até mesmo como forma de balancear a produção, quando há necessidade de aumentar a produção de aço além daquele proveniente da gusa. Cite uma ideia incorreta em relação ao trabalho com sucata e pelo menos três ideias corretas.

6. Se em uma determinada sucata se fez várias amostragens aleatórias e todas confirmaram que o material tinha 0,05\% de carbono, então, para uma tonelada de sucata, quantos quilos de carbono seria preciso adicionar (caso o rendimento da adição fosse de $100 \%$, ou seja, todo carbono adicionado se dissolvesse completamente no banho de aço líquido proveniente da fusão da sucata, considerando-se que quer alcançar um aço, com 0,15\% de carbono)?

7. Considerando-se dados de 2013, qual a porcentagem da participação da sucata na produção do aço brasileiro?

8. Em relação ao manuseio da sucata como matéria prima na fabricação de aços na siderurgia, qual aço inoxidável não é magnético?

9. O ponto de fusão da sucata de aço 0,01\% de carbono é em torno de quantos graus?

10. No carregamento de sucata em convertedor LD, o que é carregado primeiro, a gusa líquida ou sucata sólida?

11. Qual o cuidado mais importante ao se preparar uma carga de sucata, numa calha, para carregamento em convertedor LD? 


\section{PROCESSOS DE ACIARIA LD}

\section{Fala sobre:}

_ Introdução

_ Fornos convertedores

_ O produto aço

_ Dicas sobre o processo

_ Dicas sobre segurança

_ Referências Bibliográficas

_ Exercícios resolvidos 


\section{INTRODUÇÃO}

O aço é um material de engenharia por excelência, pois ele pode receber a forma final com facilidade pelos processos de conformação mecânica e pode manter seu formato em uso. Além disso, o mesmo possui excelente resistência ao desgaste, tem propriedades mecânicas e estéticas que fazem com que seja um material importante para a sociedade.

Nas siderúrgicas integradas, que possuem alta produção e produtividade, utilizam-se equipamentos denominados convertedores ou conversores LD. A aciaria é a unidade fabril onde se faz a conversão de gusa líquido em aço nos fornos convertedores LD. O termo LD se refere à origem desse tipo de equipamento que ocorreu nas cidades suíças de Linz e Donawitz.

Um processo anterior ao do sopro de oxigênio, que ocorrerá no convertedor, é a dessulfuração. Esta ocorre nas siderúrgicas que contam com equipamento de injeção de agentes dessulfurantes e que desta forma podem diminuir o teor de enxofre existente e com isso resultará numa matéria prima melhor que irá para os processos seguintes.

Como a matéria gusa proveniente do alto-forno vem em grande quantidade, normalmente, este será pesado em balanças do tipo célula de carga. Neste trabalho, o operador da ponte rolante pega a panela de gusa por meio de suas orelhas, iça e desloca até a célula de carga. Há o peso anterior da panela vazia e pelo novo peso da panela cheia, chega-se ao valor do peso de gusa líquido.

A gusa terá que ser transformada em aço. Para que isso ocorra, vamos acompanhar os processos seguintes.

\section{O FUNCIONAMENTO DO PROCESSO NOS FORNOS CONVERTEDORES}

O convertedor é um vaso ou reator químico onde ocorrem as reações entre o oxigênio e elementos químicos presentes no banho metálico líquido de ferro gusa mais sucata. Para que ocorra o processo de conversão de ferro gusa em aço, é preciso que ocorra o sopro de oxigênio sobre o banho líquido.

A figura 15 ilustra, em corte, um forno convertedor LD da aciaria de uma usina siderúrgica integrada. Na figura, pode-se ver as partes principais (lança de oxigênio puro, furo de vazamento do aço, a carcaça do convertedor e o revestimento de material refratário.

Observa-se, na parte superior e central da figura, a presença de uma lança por onde ocorre o sopro do oxigênio na velocidade aproximada do som. Não se mostram detaIhes do equipamento de basculamento do forno convertedor, que inclui um anel em volta da cintura, que é o anel munhão, e uma engrenagem gigantesca, que é o "main gear", ou engrenagem principal. Esta é ligada a um sistema de acionamento de motor e redutor. O motor elétrico de passo permite o controle correto de basculamento do convertedor. Na figura, pode-se 
Figura 15 - visão esquemática de um convertedor LD em corte mostrando suas partes principais

Fonte: autores

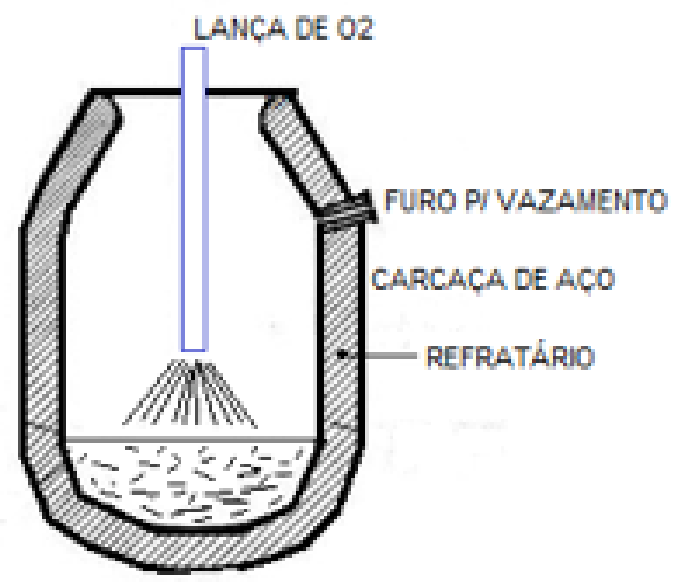

observar, também, o furo de vazamento de aço líquido.

Durante o sopro, nos primeiros cinco minutos, termodinamicamente, há a queima preferencial do silício metálico (Si), que está dissolvido em gusa e é reduzido de 4,5\% (em peso) para teores mais baixos. O sopro faz com que ocorra a reação, passando de $\mathrm{Si}$ metálico dissolvido no banho para o óxido SiO2, que é mais leve, menos denso e vai subir do banho para a escória sobrenadante.

O próximo elemento que vai reagir e sair na forma de gás é o carbono. Ele sai do limite de solubilidade, que é 6,7\% no banho.

Existem pedaços de carvão sobrenadante e, à medida que ocorre a reação química, ele vai subir como uma mistura de gases monóxido de carbono (CO) e menos dióxido de carbono (CO2). Esses gases estão quentes, à alta temperatura, mas podem ser recolhidos, pois o CO pode ser queimado à $\mathrm{CO} 2$ e, desta forma, pode haver o reaproveitamento em queima- dores, para aquecer as panelas de aço, ou os distribuidores do lingotamento, para prepará-los para o uso.

O oxigênio é injetado por meio de uma lança posicionada na parte superior do forno. O tempo de sopro varia conforme o tamanho do convertedor. Ele tem variação de 20 a 60 minutos.

A injeção ocorre à velocidade supersônica, que é garantida por meio de um Bico de Laval, que fica na parte inferior da lança de injeção. O bico da lança é de cobre eletrolítico, de altíssima pureza e é refrigerado internamente com camisa de água a alta pressão e velocidade.

O restante da lança, no qual é soldado o bico, é feito de tubos de aço especial e também é refrigerado à água. A lança é presa numa ponte especial, localizada na parte superior da instalação da aciaria. Esta conta com motores de içamento para as posições de entrada, de sopro e retida.

As operações de posicionamento da lança 
podem ser realizadas automaticamente, porém à medida que o processo está ocorrendo, o operador pode passar para o controle manual e afastar mais a lança que está aquecendo além do permitido ou então aproximar mais a lança em relação ao banho, quando precisa aumentar a temperatura.

Outros controles estão relacionados à pressão e vazão do oxigênio que pode ser alterada para acertar os parâmetros do processo de conversão: a vazão e pressão da água de resfriamento da lança e o tempo de sopro.

A carcaça do convertedor também possui refrigeração de água à alta velocidade e pressão. Por meio deste artifício garante-se uma vida prolongada para esse tipo de equipamento.

O metal líquido é muito pesado e viscoso e, por este motivo, nem todo aço presente em partes menos acessíveis ou mais distantes daquelas onde o jato toca a superfície do banho líquido de aço têm uma reação completa no interior do convertedor. Uma das formas de melhorar a homogeneidade da composição química do banho é pela injeção de gás argônio (que é um gás inerte) ou de N2 (que é um gás pouco reativo, mas que, neste caso, pode deixar um pouco de nitrogênio dissolvido no banho).

Terminado o sopro, vaza-se o metal líquido pelo bico de vazamento, basculando-se o convertedor até a posição de vazamento pelo bico. O metal líquido é vazado na panela de aço, que já deve estar pré-aquecida. Terminado o vazamento do aço, bascula-se o convertedor para o outro lado e faz-se o vazamento de escória pela boca principal do convertedor. Este novo vazamento é realizado na panela de escória.

Numa aciaria LD é necessário que se tenham vários convetedores, pois haverá fila de espera de panelas de gusa para serem carregados nos convertedores para ocorrer o sopro. Desta forma, há usinas que operam com dois convertedores, no mínimo, outras com três, quatro ou cinco e, à medida que se possui mais convertedores, pode-se operar com mais facilidade e de modo mais contínuo e seguro possível. A operação com dois convertedores é muito árdua, pois, caso um equipamento pare para manutenção, o outro terá que funcionar no seu limite, com riscos de paradas e prejuízos maiores.

Os processos seguintes podem incluir uma estação de desgaseificação do aço, pois há muitas bolhas e gases provenientes dos processos anteriores. Posteriormente, vem o lingotamento onde se fará o resfriamento e solidificação do aço.

\section{APLICAÇÃO}

Considere a existência de um alto-forno com 150 toneladas de gusa líquido por hora. Se contarmos com 3 convertedores operando a pleno trabalho (60 toneladas/ hora e considerando-se que as perdas de processo sejam desprezíveis), cada uma com ciclo de carregamento, sopro e descarga de uma hora, observe que em uma hora pode-se produzir 180t de aço. Mas, se o alto-forno manda somente 150t, 
de onde virão as 30t restantes? Resposta: pode ser que elas venham da carga de sucata, que a cada $50 t$, seria completada com 10 t de sucata na carga do forno.

Observa-se que a carcaça do convertedor, para mais de 60 toneladas de aço por corrida, é de aço de mais de uma polegada de espessura e que internamente há um revestimento de refratário, que vai entrar em contato direto com o metal líquido. Verifica-se também que, para que ocorra a operação correta, antes do primeiro uso, o convertedor tem que passar por um ciclo de várias horas para o aquecimento dos refratários até próximo à temperatura de trabalho, para evitar que no contato entre o metal e uma superfície fria, ocorra a solidificação do aço com prejuízos maiores para os processos.

\section{CONSIDERAÇÕES FINAIS}

Aciarias são as unidades fabris das siderúrgicas integradas, onde se processa a gusa líquida proveniente do alto-forno e procura-se transformá-lo em aço líquido, por meio do sopro de oxigênio. Este sopro, que é feito à alta pressão e velocidade sobre o banho líquido, faz com que se oxidem, preferencialmente nos cinco primeiros minutos, o silício contido no banho e posteriormente o carbono. Este sopro pode durar cerca de 15 a 20 minutos nos convertedores pequenos e cerca de 40 minutos nos convertedores maiores. O ciclo, incluindo o carregamento, sopro e descarregamento, é de cerca de uma hora nas aciarias. É preciso lembrar que podem existir vários convertedores operando em paralelo, de modo a se formar uma fila de espera para ver qual será o equipamento da vez, que receberá a próxima carga de gusa líquida.

De forma semelhante, à medida que o aço vai sendo produzido, na saída da aciaria, ele deverá ir para o próximo processo, que ocorre na próxima estação, que é o lingotamento. $\mathrm{Na}$ hora do vazamento do aço líquido produzido no convertedor, pode-se fazer a adição de ferros liga, por exemplo: a adição de ferro cromo e ferro níquel pode fazer com que se produza o aço inoxidável, que é uma liga de ferro-cromo e níquel. Este aço tem uma grande resistência à corrosão, pois no seu uso cotidiano, forma-se uma camada protetora de óxido de cromo, que protegerá o material contra a corrosão. Desta forma, o aço inox estará sempre com aspecto bom e fornecendo uma impressão de limpeza.

O aço é um dos produtos mais importantes para a humanidade. Quando se baixa o teor de carbono do ferro gusa e se transforma esse material em aço, ocorre um ganho de propriedades de estampabilidade, dureza, resistência e outros que fazem com que o material seja muito importante para a fabricação de peças, que serão utilizadas em máquinas e também na fabricação de instalações industriais e domiciliares.

A aciaria LD é uma unidade de alta produtividade. Ela precisa acompanhar o ritmo da produção do alto-forno, e faz isso por meio da distribuição da gusa entre os vários convertedores. É interessante se ter pelos 
menos três convertedores (40 minutos de ciclo entre carregamento e vazamento em cada convertedor), podendo um deles estar em manutenção e outros dois em operação.

Outro fator de produtividade está relacionado com o balanceamento de carga de trabalho entre as unidades fabris. Observa-se que, após o convertedor, as etapas seguintes incluem a desgaseificação, adição de ligas, lingotamento contínuo, laminação etc.

Há necessidade de um bom balanceamento entre as unidades que necessitam de programações de produção e de alterações continuamente para se adaptar ou se ajustar ao ambiente dinâmico de produção. É muito comum algum equipamento sair de operação e se necessitar realizar a reprogramação da utilização dos equipamentos e da alocação de pessoal.

\section{DICAS PARA OS ENGENHEIROS, TECNÓLOGOS, TÉCNICOS E PESSOAL DE OPERAÇÃO}

- Processos agregam valores aos materiais. Cada processo na aciaria, começando anteriormente pela estação de dessulfuração, pesagem, carregamento do convertedor, sopro, adição de ligas no vazamento na panela pré-aquecida e desgaseificação acrescentam valor ao produto, ou seja, os processos têm custos e, à medida que o material vai sendo processado, ele passa a ser um material mais nobre e com caracte- rísticas melhoradas.

_ A aciaria é o local onde se faz o processo de conversão da gusa ou da sucata em aço. Este é um material que vai apresentar propriedades mecânicas, que o torna útil para construção de trilhos ferroviários, tubulações, autopeças, carcaça de eletrodomésticos, cutelaria etc.

- Existe uma gama grande de peças e instalações que podem ser fabricadas em aço. Para tanto, na aciaria, faz-se a definição do tipo de aço: se será um aço ao carbono simples ou se haverá o processo de adição de ligas para fazer, por exemplo, um aço inoxidável, ou algum outro tipo de aço. Em termos comparativos, um aço liga pode alcançar centenas de vezes o valor em relação a um aço comum. Daí pode-se começar a entender a importância dos processos necessários para a fabricação de um aço mais nobre que pode passar em seus processos produtivos, por dessulfuração, desgaseificação, adição de ligas etc.

- Observa-se que é importante que as aciarias contem vários fornos convertedores para poder fazer o jogo e atender ao escoamento de produção em relação à gusa que vem do alto-forno, pois sempre algum equipamento pode estar em manutenção e os outros têm que dar vazão, caso contrário, a gusa que está em espera nos carros torpedos ou nas panelas de gusa pode ir perdendo temperatura e se solidificar, gerando inicialmente o "cascão" e, na continuidade do processo, se não ocorrer alguma contra medida, pode fazer com que se perca a panela ou o carro torpedo, 
se o material líquido se solidificar no interior dele.

_ Há também siderúrgicas que possuem o processo de desgaseificação que aumenta os custos mais produz aço de melhor qualidade, isento de bolhas de gás.

\section{BIBLIOGRAFIA CONSULTADA}

[1] . ARAÚJO, Luis A. Siderurgia. São Paulo: Arte e Ciência, 2009. v.1 e 2.

\section{EXERCÍCIOS}

1. Quais elementos de liga principais tornam os aços inoxidáveis?

2. Por que muitos aços têm que ter baixo teor de enxofre?

3. Existe algum interesse em se adicionar silício como elemento de liga aos aços?

4. A lança de sopro de oxigênio é refrigerada internamente por água à alta velocidade e pressão. De que material é feito o bico da lança?

5. Nas aciarias das siderúrgicas integradas a grande maioria trabalha com fornos convertedores LD. Qual a origem desta sigla?

6. Considerando-se um convertedor LD de 100 t de banho metálico, o que se pode dizer que ocorre em termos de reação química nos primeiros cinco minutos de sopro de oxigênio?

7. Quais os cuidados no carregamento da sucata num convertedor LD?

8. Em relação à temperatura de vazamento, que é realizado após o sopro de oxigênio num convertedor LD, qual deve ser a temperatura e que vantagens tem a temperatura mais elevada ou não?

9. Em relação ao processo de sopro que ocorre no interior do convertedor LD, durante esse processo, o que ocorre com a temperatura no banho de aço?

10. Fale sobre o risco do material se solidificar no interior do carro torpedo ou da panela de gusa. 


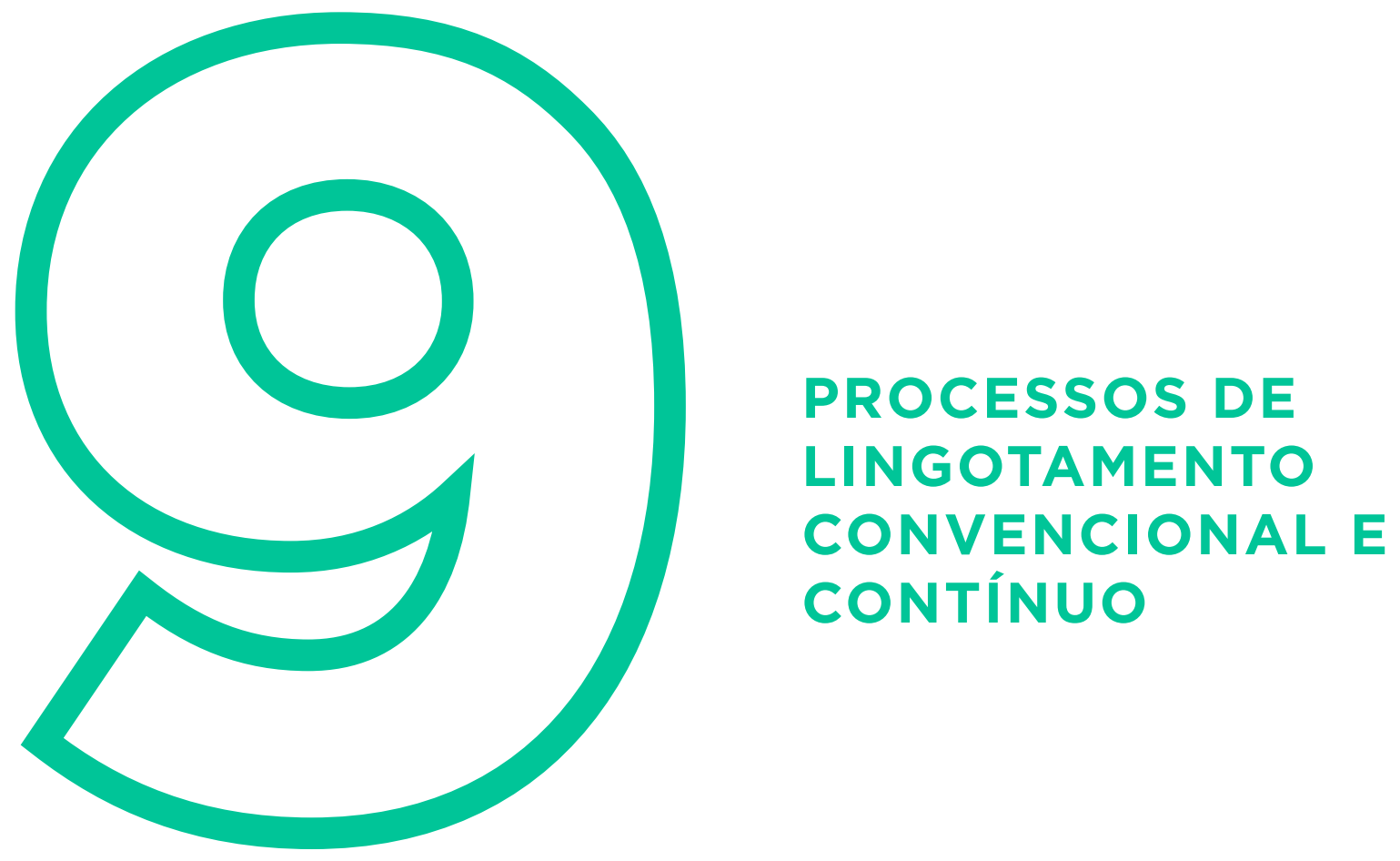

Fala sobre:

_ Introdução

_ Comparação entre lingotamento contínuo e convencional

_ O produto (placas e lingotes)

_ Dicas sobre o processo

_ Dicas sobre segurança

_ Referências Bibliográficas

_ Exercícios resolvidos 


\section{INTRODUÇÃO}

Todo metal que é fundido em fornos metalúrgicos precisa, posteriormente, ser resfriado para formar peças à temperatura ambiente. Lingotamento é processo em que o aço líquido será transformado em aço solidificado. Esse processo resultará em aço com algum formato. Este poderá ser processado posteriormente para diminuir a espessura ou modificar o formato.

Antigamente, o vazamento ocorria em lingoteiras de ferro fundido, que eram formas que recebiam o aço líquido no seu interior. Neste recipiente, o aço ficava solidificando durante horas até formar um bloco sólido, que é o lingote. Este, posteriormente, seria aquecido à temperatura elevada (abaixo do ponto de fusão), mas suficiente para que adquirisse propriedades de plasticidade e pudesse passar para o processo seguinte, que é o da laminação.

No lingotamento convencional, utiliza-se várias lingoteiras de ferro fundido em cima de vagões ferroviários. As lingoteiras eram fabricadas numa instalação de fundição que ficava localizada dentro da usina siderúrgica. $\mathrm{Na}$ instalação das lingoteiras, preparando-as para o vazamento, elas eram posicionados em cima de placas de base. Entre a lingoteira e a placa de base, colocava-se um cordão de uma pasta refratária.

A lingoteira também passava por uma pintura interna de material, que facilitava o descolamento para a retirada do lingote solidificado e que era feito numa máquina de estripamento (esta era uma ponte rolante que tinha duas garras que pegavam as lingoteiras e elevavam; no centro, vinha uma peça que aplicava uma pancada no sentido descendente para liberar o lingote da lingoteira e, desta forma, fazia a retirada do lingote). Este tinha que passar por reaquecimento durante horas para chegar a uma temperatura que permitisse que fosse laminado.

Ao longo do tempo, houve o domínio do processo de lingotamento e passou-se a fabricar máquinas que faziam o lingotamento contínuo do aço. Este processo representou um grande avanço, pois houve mais produtividade e economia de tempo, dinheiro e esforços.

As máquinas e instalações de lingotamento contínuo são muito mais caras e modernas com muitos controles e instrumentos de medição eletrônicos, porém, como a produção, produtividade e qualidade são muito maiores, essas máquinas e instalações se pagam ao longo do seu uso.

Além disso, o veio ou material que vai se solidificando no lingotamento contínuo, ao concluir a solidificação, é cortado por meio de máquinas de oxicorte e a chapa grossa pode aproveitar o calor e ir para o processo seguinte de laminação, economizando energia por evitar que seja necessário o reaquecimento do material para laminação. Outro ponto positivo é que o molde do lingotamento contínuo já produz uma chapa grossa e, desta forma, se economiza em passes de laminação. Com isso se barateia os custos dos processos. 
COMPARAÇÃO ENTRE O LINGOTAMENTO CONVENCIONAL E O CONTÍNUO

O lingotamento convencional ocorre com as lingoteiras posicionadas em cima de bases e que ficam localizadas em cima de vagões ferroviários.

Verifica-se, pela figura a seguir, que há uma grande perda de tempo, pois cada lingoteira (de 20t cada, por exemplo) deverá ser enchida com aço, passando-se para a próxima. Ocorre que não há precisão nos processos, de modo que, se uma lingoteira ficar com 18t e outra com $21 \mathrm{t}$, isso é normal. Também a passagem de uma lingoteira para outra exige um certo conjunto de procedimentos que gastam tempo. Outro fator importante é o reaquecimento dos lingotes para que ocorra o processo seguinte de laminação, que faz com que se gaste mais energia.

O lingotamento convencional ocorre com as lingoteiras posicionadas em cima de bases e que ficam localizadas em cima de vagões ferroviários.

A figura 16 apresenta dois tipos usuais de lingoteiras cônicas, sendo que a figura 16A é um exemplo de uma lingoteira com base maior voltada para baixo e a figura 16B uma lingoteira com base maior voltada para cima.
Figura 16 - exemplos ilustrativos de dois tipos usuais de lingoteiras cônicas, sendo (A) representando uma lingoteira com base maior voltada para baixo e (B) uma lingoteira com base maior voltada para cima.

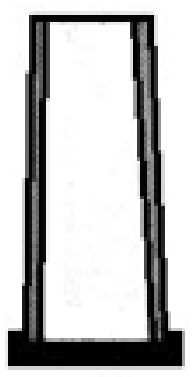

(A)

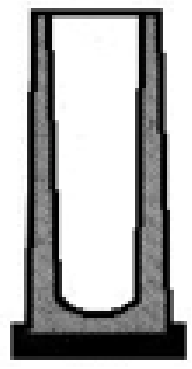

(B)
A figura 17 mostra as partes principais de uma instalação de um processo de lingotamento continuo.

As máquinas de lingotamento contínuo possuem muitas partes: alguns roletes são extratores e, portanto, são acionados enquanto outros são de encosto e, portanto, não são acionados, ou seja, não contém conjuntos motores, redutores e de acoplamento aos cilindros.

O distribuidor é forrado internamente por tijolos refratários e abaixo dele há também outras válvulas gavetas, uma para cada veio de aço. Estas são importantes para o operador controlar o nível de aço que está sendo vazado, de modo a não ocorrer um transbordamento do molde. Não se mostram os controles e os operadores nem a casa na qual os equipamentos estão instalados. 
Figura 17 - principais partes da instalação de um processo de lingotamento contínuo

Fonte: autores

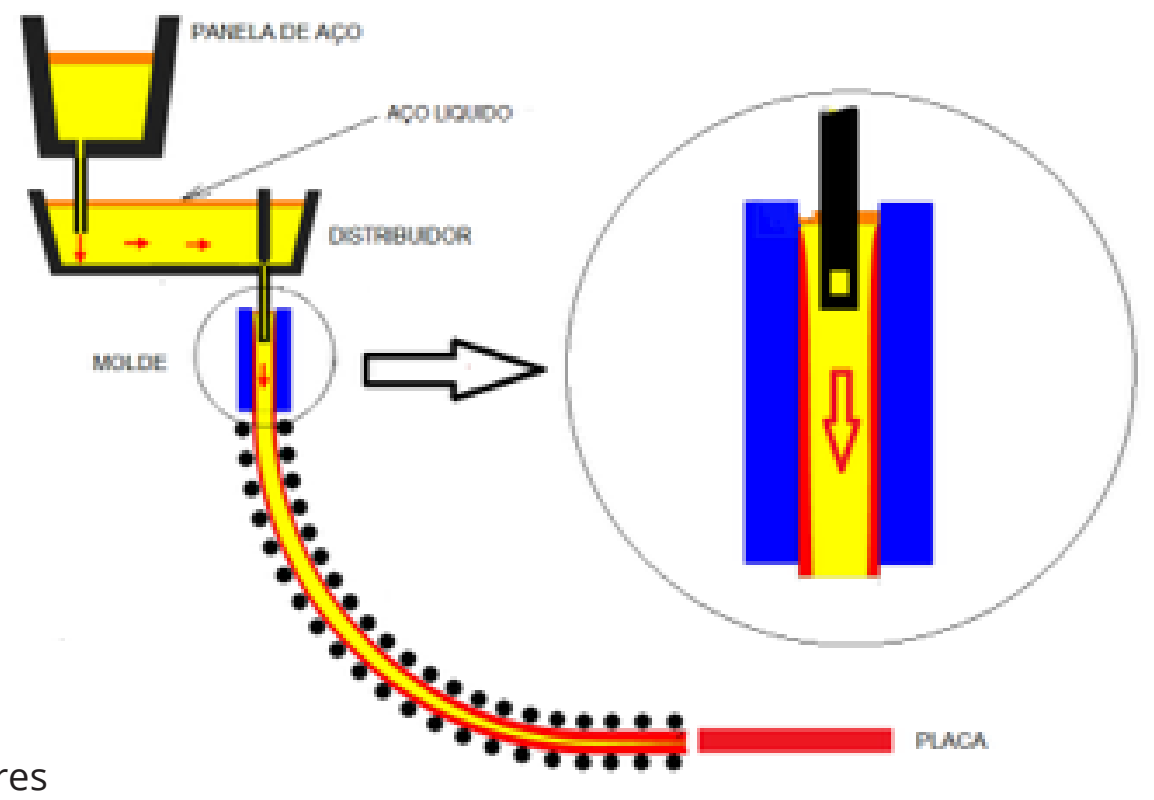

Não se mostra, na imagem abstraída, os detalhes dos mecanismos de oscilação e de acionamentos, nem os locais de medição das temperaturas, os bicos jateadores de água e menos ainda o vapor gerado em grande quantidade, durante a operação dos sistemas, pois numa abstração apresentam-se somente os detalhes necessários para se compreender o funcionamento do conjunto.

Observa-se que podem acontecer acidentes, como é o caso do estouro de veio. Este ocorre quando existe uma pele mal formada que deixa vazar o aço líquido, que cai sobre os roletes e devido à presença de água que se aquece e vira vapor (observe que um litro de água pode gerar 1000 litros de vapor nas mesmas condições de pressão e se não houver um volume livre pode-se aumentar a pressão e ter um efeito bomba).

Verifica-se, na figura 17, um detalhe do corte do molde que é visto ampliado. Logo após sair do molde, há os roletes extratores e a localização deste conjunto é num nível abaixo do piso da sala de controle, onde há burrifos de água na superfície ou casca de metal solidificado que está se formando.

A finalidade deste burrifo que ocorre nos lados superior e inferior da placa formada é a da refrigeração.

O interior do produto formado ainda está no estado líquido e somente na saída do raio de curvatura é que a solidificação se completa e o material está pronto para o corte e para seguir para o próximo processo que, em geral, é aquele de laminação.

$\mathrm{Na}$ parte central da figura se apresenta uma instalação com um distribuidor e dois veios em paralelo no lingotamento de slabs ou chapas grossas. Já na instalação, mais à direita do leitor, há um lingotamento contínuo de quatro veios de tarugos, em geral, com dimensões próximas a 120 x $120 \mathrm{~mm}$. 
O Quadro 3 apresenta uma comparação mento convencional e contínuo. resumida entre os processos de lingota-

Quadro 3 - Comparação entre processos de lingotamento.

\begin{tabular}{|c|c|c|c|c|c|c|}
\hline $\begin{array}{l}\text { Tipo de } \\
\text { lingota- } \\
\text { mento }\end{array}$ & $\begin{array}{c}\text { Consumo } \\
\text { de ener- } \\
\text { gía nos } \\
\text { processos } \\
\text { posteriores }\end{array}$ & $\begin{array}{l}\text { Descarte } \\
\text { de ma- } \\
\text { terial de } \\
\text { pontas e } \\
\text { sobras }\end{array}$ & $\begin{array}{c}\text { Neces- } \\
\text { sidade } \\
\text { de ope- } \\
\text { rações e } \\
\text { funcio- } \\
\text { nários }\end{array}$ & $\begin{array}{c}\text { Poluí- } \\
\text { ção }\end{array}$ & $\begin{array}{l}\text { Tempo } \\
\text { de pro- } \\
\text { cessa- } \\
\text { mento }\end{array}$ & $\begin{array}{c}\text { Custo } \\
\text { final por } \\
\text { tonelada } \\
\text { de aço } \\
\text { produzi- } \\
\text { do }\end{array}$ \\
\hline Convencional & Maior & Maior & Maior & Maior & Maior & Maior \\
\hline Continuo & Menor & Menor & Menor & Menor & Menor & Menor \\
\hline
\end{tabular}

Fonte: autores

Verifica-se que o lingotamento contínuo é muito mais econômico que o convencional e, por este motivo, está sendo utilizado na maioria das usinas do mundo.

Por outro lado, existe uma necessidade maior de controle e automação para se fazer frente ao trabalho dinâmico de resfriamento e solidificação do veio de lingotamento contínuo.

Os processos de lingotamento podem fazer com que as siderúrgicas economizem muito dinheiro e aumentem seus lucros. Estes processos, quando são contínuos, necessitam de muita automação para o controle dos processos de modo dinâmico e desta forma, podem aumentar a produção e produtividade nessas organizações.

\section{APLICAÇÃO}

Quando se trabalha com lingotamento contínuo, o material que sai do lingotamento ainda está muito quente e é possível se aproveitar esse calor e fazer continuadamente o processo seguinte de laminação, considerando-se que o material ainda está relativamente macio e tem facilidade em ser trabalhado pelo processo de laminação, sem necessidade de reaquecimento e consumo de combustível.

Outro ponto favorável é a economia em relação aos descartes que, no caso do lingotamento convencional, ocorrem com o corte de parte da cabeça e de parte do rabo do lingote, devido à parte final contar com impurezas e as partes inicial e final contarem com formatos que nem sempre são aproveitáveis.

O processo de lingotamento das siderúrgicas é realizado nas unidades fabris de lingotamento. Nestas se recebe o aço líquido que vem em panelas e ocorre o vazamento que geralmente se faz pela parte inferior das panelas de aço, onde existe uma válvula gaveta que permite a abertura e o fechamento do jato de aço líquido pela parte inferior da panela de aço. 


\section{CONSIDERAÇÕES FINAIS}

Lingotamento de aço é o processo de resfriamento do aço em moldes metálicos, denominados lingoteras de ferro fundido, no caso do processo convencional, ou então, em molde de cobre de altíssima pureza e que seja refrigerado por água à grande pressão e velocidade e que conte com movimento de oscilação para facilitar o desgrudamento do material solidificado em relação ao molde.

O processo de lingotamento contínuo é de alta produtividade, porém exige um controle maior das variáveis de processo que, além da composição química do aço, incluem a temperatura do aço líquido na hora do vazamento, a velocidade de extração do material solidificado, a temperatura na superfície do material solidificado, a temperatura de saída da água de refrigeração do molde, a velocidade de oscilação e o curso de oscilação do molde etc.

O lingotamento é uma das etapas importantes no processo de fabricação do aço. O material lingotado terá um formato, como é o caso de slabs ou chapas grossas, tarugos ou barras circulares, e irá posteriormente para outros processos, visando à obtenção de algum produto mais final.

Nos processos de lingotamento, pode-se economizar energia, materiais, tempo, mão-de-obra e, com isso, a empresa pode ganhar muito dinheiro nesses processos contínuos, mas para isso é preciso trabaIhar bem e com boas equipes, pois no caso da produção incorreta e de modo contínuo, o prejuízo também pode ser muito grande.

Por outro lado, existe uma necessidade muito maior de controle e automação nos processos de lingotamento contínuo.

A operação do lingotamento contínuo deve ser realizada por pessoal bem treinado, preparado e experiente, pois, apesar de não tão frequente, podem acontecer fenômenos indesejáveis, como é o caso do estouro de veio do lingotamento, causando uma verdadeira explosão.

\section{DICAS PARA OS ENGENHEIROS, TECNÓLOGOS, TÉCNICOS E PESSOAL DE OPERAÇÃO}

_ O lingotamento convencional também é um momento no qual se pode fazer alguma adição de elementos de liga, pois há a agitação do metal líquido enquanto ele é vazado no interior da lingoteira, porém é menos recomendável se fazer esse tipo de adição neste local, pois há menos chance de sucesso em relação à adição na panela de aço durante o vazamento. Já no lingotamento contínuo, não se recomenda a adição no molde porque, neste caso, há uma solidificação mais rápida e pode não haver tempo para ocorrer alguma homogeneização do material.

_ O pessoal que trabalha com lingotamento convencional ou com o contínuo está trabalhando próximo de material de aço líquido à alta temperatura e tem que 
tomar cuidado para não se ferir. Deve-se seguir todos os procedimentos de segurança da área em consideração. Deve-se ter muito preparo prévio, simulações de operação e trabalho conjunto com outras pessoas experientes antes de entrar numa área como essa para trabalhar.

- Outro ponto muito importante se refere aos procedimentos de segurança a serem adotados em casos emergenciais. Um exemplo disso é quando ocorre um estouro de veio. Este pode ocorrer quando, por algum motivo, a pele do aço em solidificação no lingotamento contínuo não estava bem formada e, ao se romper, deixa vazar aço líquido que em contato com a água de resfriamento da superfície do veio na câmara de resfriamento vai causar uma explosão. Os operadores têm que suspender imediatamente o vazamento e desviar o aço líquido para alguma panela reserva que necessariamente tem que estar disponível nas proximidades. As panelas de aço ainda cheias, se possível, devem ser levadas para outras máquinas de lingotamento. Caso contrário, se houver possibilidade, sempre se deixa algum vagão com lingoteiras convencionais preparados nas proximidades para se realizar o vazamento nessas lingoteiras. Se isso não ocorrer, pode acontecer a solidificação de aço no interior da panela de aço e em casos extremos isso pode levar à perda da panela que poderá (nos casos extremos que não se permita recuperação) ter que ser cortada e carregada como sucata nos junto à carga dos convertedores LD, posteriormente.

\section{BIBLIOGRAFIA \\ CONSULTADA}

[1]. ARAÚJO, Luis A. Siderurgia. São Paulo: Arte e Ciência, 2009. v.1 e 2. 


\section{EXERCÍCIOS}

1. No lingotamento convencional em relação ao contínuo, como fica o consumo de energia? E em relação ao descarte de material de pontas e sobras? E ainda em relação à necessidade de operações e funcionários?

2. Numa siderurgia integrada, em relação ao lingotamento, ele é uma etapa que vem após qual processo?

3. Em relação ao lingotamento contínuo de aço, cite três equipamentos que são desta área de processamento.

4 . Apresente três características em relação ao processo de lingotamento contínuo.

5. No lingotamento convencional onde começa a solidificação e qual a direção de solidificação?

6. O que acontece no último local do aço que está se solidificando no interior de lingoteiras no lingotamento convencional?

7. Os lingotamentos convencionais foram extintos ou ainda existem nas usinas que trabalham com lingotamento contínuo?

8. Em relação à água que é utilizada para refrigeração na camisa de água do molde de cobre do lingotamento contínuo, cite pelo menos três características.

9. Qual a finalidade do conjunto que realiza a oscilação no molde de cobre de lingotamento contínuo?

10. Como é feita a operação de início de lingotamento no molde de cobre? 


\section{PROCESSOS DE LAMINAÇÃO A QUENTE}

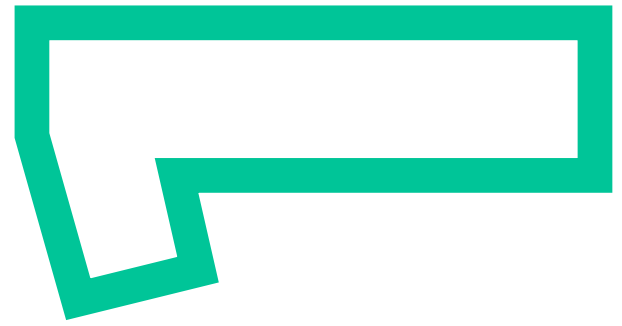

\section{Fala sobre:}

_ Introdução

_ Laminadores

_ Tipos de cilindros de laminação

_ Fornos de reaquecimento de placas

_ Processo de laminação a quente

_ Referências Bibliográficas

_ Exercícios resolvidos 


\section{INTRODUÇÃO}

Devido à influência do mercado de demandar materiais cada vez mais finos, existe a necessidade de se utilizar equipamentos cada vez mais sofisticados para atender as características de qualidade e produtividade.

\section{LAMINADORES}

Um laminador consiste basicamente de cilindros (rolos), mancais, uma carcaça, também chamada de gaiola, que serve de suporte para as principais partes, e um motor elétrico para fornecer energia mecânica aos cilindros. Todos os laminadores são dotados de um apurado controle de velocidade de rotação.

As forças envolvidas na laminação chegam a atingir milhares de toneladas, o que justifica a necessidade de uma estrutura bastante rígida. Outro detalhe são os motores, que são de elevada potência devido à necessidade suprimir as energias mecânicas necessárias.

O custo de uma moderna instalação de laminação é da ordem de milhões de dólares e são necessários projetos bem elaborados, uma vez que esses requisitos são multiplicados para as sucessivas cadeiras de laminação contínua - são os chamados Tandem mill.

Num processo de laminação utilizam-se variadas disposições de cilindros, sendo que o mais simples é constituído por dois cilindros de eixo horizontais, colocados verticalmente um sobre o outro. Este equipamento é chamado de laminador duo, podendo ser reversível ou não. Nos duos não reversíveis, o sentido do giro dos cilindros não pode ser invertido e o material só pode ser laminado em um sentido. Nos laminadores reversíveis, a inversão da rotação dos cilindros permite que a laminação ocorra nos dois sentidos, ou seja, o produto laminado pode ir para frente e para trás. Isto resulta num ganho de produtividade.

No laminador trio, os cilindros sempre giram no mesmo sentido, porém o produto pode ser laminado nos dois sentidos, passando-o alternadamente entre o cilindro superior e o intermediário e entre o intermediário e o inferior.

Devido a influência do mercado de demandar materiais cada vez mais finos, há necessidade de se utilizar cilindros de trabalho com diâmetros cada vez menores.

Durante o processo de laminação estes cilindros sofre uma deflexão. Em virtude disso, ocorre a necessidade do projeto do cilindro de apoio - comumente chamado de cilindros de encosto. Este tipo de laminador denomina-se quádruo, podendo ser reversível ou não.

No caso de laminadores com cilindros de trabalho muito finos - chamados de laminadores Sendzimir - ocorre uma flexão tanto na direção vertical quanto na horizontal. Eles devem ser apoiados em ambas as direções.

Os cilindros de laminação, normalmente são fabricados de aço, sendo que os de trabalho são forjados e os cilindros de apoio 
são de aço fundido. Eles são compostos de três partes: a mesa, onde se realiza a laminação; os pescoços, onde se encaixam os mancais; e os trevos ou garfos de acionamento. É importante citar que após a laminação de uma certa tonelagem de produtos, conforme programação da planta, os cilindros passam por uma retífica de forma a refazer o corpo de laminação. Normalmente esta retífica retira, na superfície dos cilindros, uma fina camada - microns.

Quanto aos mancais dos cilindros são usados três tipos diferentes: mancais de fricção, onde o pescoço gira sobre casquiIhos de bronze; mancais de rolamento e mancais lubrificados com um filme de óleo sob pressão - são os chamados "Morgoil", sendo este último o mais eficiente.

\section{TIPOS DE CILINDROS DE LAMINAÇÃO}

Os cilindros de laminação são produzidos em uma enorme variedade de materiais, desde o aço simples com 0,50\% de carbono, passando pelos ferros fundidos especiais e nodulares, até os carbonetos de tungstênio.

\section{CILINDROS DE AÇO}

Os cilindros de aço são cilindros com alto teor de carbono (0,35 a 1\%) e elementos de liga que passam por tratamentos térmicos adequados e com isso obtém-se: altas durezas e resistências adequadas. Os principais elementos de liga são o cromo, o níquel e o molibdênio.

\section{CILINDROS DE AÇO FUNDIDO}

Os cilindros de aço fundido apresentam resistência ao desgaste relativamente baixa, mas, devido à sua alta resistência à flexão, permitem grandes reduções em cada passagem; são usados, principalmente, nos laminadores desbastadores, nas primeiras cadeiras de laminadores de tiras a quente e como cilindros de encosto nos laminadores planos a quente e a frio.

\section{CILINDROS DE AÇO FORJADO}

Cilindros de aço forjado são os que apresentam maior resistência ao desgaste superficial; são usados principalmente como cilindros de trabalho nos laminadores a frio.

\section{CILINDROS DE FERRO FUNDIDO EM MOLDES DE AREIA}

Cilindros de ferro fundido em moldes de areia são empregados como cilindros acabadores de trens de grandes perfis e trens comerciais, bem como cilindros preparadores de trens de perfis médios.

\section{CILINDROS DE FERRO FUNDIDO COQUILHADO}

Cilindros de ferro fundido coquilhado são cilindros com camada exterior bastante dura; possuem alta resistência ao desgaste e com isso os produtos apresentam um bom acabamento superficial. O núcleo, no 
entanto, é mais tenaz e apresenta boa resistência à ruptura. Esses cilindros podem ser usados em cadeiras acabadoras de trens de fio-máquina, de trens de pequenos perfis, e em laminadores desbastadores.

\section{FORNOS DE REAQUECIMENTO}

Os fornos de reaquecimento são utilizados com a finalidade de elevar a temperatura dos produtos semi-acabados (tarugos ou placas), até que o material esteja suficientemente plástico para permitir a redução mecânica à seção almejada.

Estes fornos, normalmente contínuos, possuem, em geral, várias zonas de aquecimento em seu interior. O material a ser aquecido é posicionado na entrada do forno e forçado a caminhar pelo interior através da ação de empurradores ou vigas. Nestes fornos, tanto a carga como a descarga, se realizam de maneira periódica durante a operação. São fornos com elevada produção e baixa taxa de mão-de-obra por tonelada produzida.

É interessante observar detalhes tais como:

_ Temperatura deve ser suficiente (mais alta possível) de forma tal que não haja necessidade de reduzir a velocidade de produção do laminador, nem submeter os cilindros a pressões excessivas;

- Superaquecimento deverá ser evitado, pois a temperatura demasiadamente elevada irá afetar a seção transversal, o que poderá alterar propriedades físicas do produto acabado;
- Uniformidade de aquecimento é interessante. O produto deve ser uniforme em toda a seção e em todo o comprimento. Isto evita aparecimento de rupturas internas;

- Fusão da superfície externa deve ser evitado. O aquecimento deve permitir o fluxo adequado de calor. Isto é para evitar trincas e tensões internas, causadas por diferenças muito grandes de temperatura entre o núcleo e a superfície da peça.

\section{LAMINAÇÃO A QUENTE}

A laminação é um processo de conformação mecânica no qual o material é forçado a passar entre dois cilindros, girando em sentidos opostos, com praticamente a mesma velocidade superficial e separados entre si de uma distância menor que o valor da espessura inicial do material a ser deformado, de forma a reduzir a área de sua seção transversal.

Isso pode ser considerado como uma etapa inicial do processo de laminação. No caso de placas e chapas, o processo é bastante semeIhante ao estiramento, apresenta um bom controle dimensional e alta produtividade, em virtude da continuidade de seu processo.

Primeiramente, a peça inicial, comumente um lingote fundido pelo processo convencional, ou uma placa (ou tarugo), processado previamente em lingotamento contínuo, é aquecida a uma temperatura elevada - no caso de aços, inicia entre $1100^{\circ} \mathrm{C}$ e $1300^{\circ} \mathrm{C}$, que é uma temperatura acima da chamada temperatura de recristalização e termina entre $700^{\circ} \mathrm{C}$ e $900^{\circ} \mathrm{C}$, 
temperatura esta denominada de temperatura de acabamento (TA).

No final do trem de laminação, a temperatura da bobina fica em torno de $650^{\circ} \mathrm{C}$, temperatura esta denominada de temperatura de bobinamento (TB).

É importante salientar que estas duas temperaturas - de acabamento e de bobi- namento - devem ter um bom controle. Elas têm grande influência nas microestruturas finais, o que resulta em definição das propriedades mecânicas do produto final.

A figura 18 apresenta a variação que ocorre na forma e tamanho dos grãos (microestrutura) antes e após o processo de deformação a quente.

Figura 18 - representação da variação que ocorre na forma e tamanho dos grãos antes e após o processo de deformação a quente

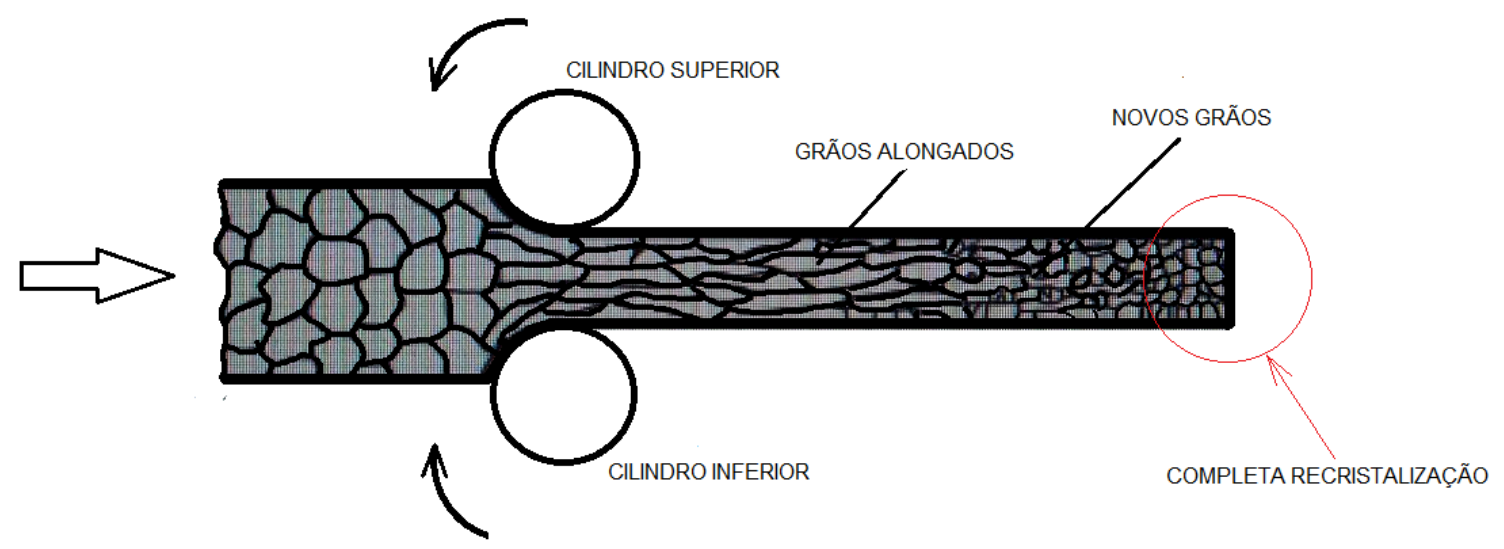

Fonte: autores

Pode-se observar que a granulação se alonga no início da deformação entre os cilindros e, em seguida, vai ocorrendo criação de novos grãos até o atingimento da recristalização completa.

O produto, após a laminação a quente, adquire formas de perfis diversos (produtos não planos) ou de placas e chapas (produtos planos).

Comumente se aplica nas operações iniciais um desbaste, onde são necessárias grandes reduções de seções transversais.

No caso das placas, elas são laminadas até chapas grossas (material mais espesso) ou tiras a quente. Na laminação de tiras, com espessuras na ordem de 2,0 milímetros, comumente utilizam laminadores duos ou quádruos reversíveis numa etapa preparadora e um trem contínuo de laminadores quádruos.

O material, após a laminação, é então bobinado a quente, decapado e oleado, indo a seguir para o mercado consumidor como produto laminado a quente ou é direcionado para a laminação a frio.

É interessante salientar que, com a utilização do lingotamento contínuo, produzem-se placas e tarugos diretamente da máquina, evitando-se, assim, uma série 
de operações de laminação, em especial a laminação desbastadora.

A presença de óxidos superficiais na chapa laminada a quente é uma característica do produto. Quando a chapa tiver que sofrer processamentos posteriores, há necessidade de sua remoção. Como exemplos, podemos citar os casos de aço destinados a estampagem, principalmente indústria automotiva. Devem ser removidos porque eles reduzem a vida da ferramenta e causam defeitos superficiais na peça durante o processo de estampagem. Os óxidos impedem a aderência de revestimento superficial, tais como estanho, zinco ou pintura. Durante a laminação a frio, os óxidos causam defeitos superficiais.

O principal processo de remoção de óxidos superficiais é a decapagem, que consiste na imersão da peça num banho de solução de ácidos inorgânicos (clorídrico ou sulfúrico) em água durante um determinado tempo. Esses banhos podem conter ainda agentes inibidores e umectantes. As instalações para esse processamento podem ser dos tipos: decapagem por lotes, decapagem semi-contínua e decapagem contínua. Para completar o tratamento superficial, as chapas são comumente oleadas para efeito de proteção contra a corrosão até sua utilização.

\section{DICAS PARA OS ENGENHEIROS, TECNÓLOGOS, TÉCNICOS E PESSOAL DE OPERAÇÃO}

- Utilizar sempre os procedimentos de segurança da área de trabalho. Andar somente em locais determinados. Observar as placas de sinalização. Utilizar os EPIs recomendados pela área local.

\section{REFERÊNCIAS}

[1]. ASHBY, M. F.; JONES, D. R. H. Engineering materials: an introduction to their properties \& applications. London: Butterworth Heinemann, 2001.

[2]. CENTRO DE INFORMAÇÃO METAL MECÂNICA - CIMM. Disponível em: < www. cimm.com.br>. Acesso em: 20 março de 2015.

[3]. CETLIN, P. R.; HelMAN, H. Fundamentos da conformação mecânica dos metais. Belo Horizonte: Artliber, 2002.

[4]. CHIAVERINI, Vicente. Aços e ferros fundidos. São Paulo: ABM, 2005.

[5]. CHIAVERINI, Vicente. Tecnologia mecânica: estrutura e propriedades das ligas metálicas. São Paulo: McGraw-Hill, 1986.

[6]. MEYERS, M. A. Mechanical behavior of materials. Hardcover, 2008.

[7]. PARANHUS FILHO, Moacyr. Gestão da produção industrial. Curitiba: IBPEX, 2007. 


\section{EXERCÍCIOS}

1. Quais são, basicamente, as principais partes de um laminador?

2. Quais as vantagens de laminador reversível em relação a um não reversível?

3. Porque existe uma demanda de chapas finas no mercado consumidor?

4. Porque é necessário uma retifica nos cilindros?

5. Porque a temperatura deve ser o mais alto possível dentro dos fornos de reaquecimento de placas?

6. O que significa temperatura de acabamento?

7. O que significa temperatura de bobinamento?

8. Porque a laminação a quente deve ser feita acima da temperatura de recristalização dos aços?

9. Porque devem ser retirados os óxidos após laminação a quente?

10. Qual a espessura final que se consegue atingir durante o processo de laminação a quente? 


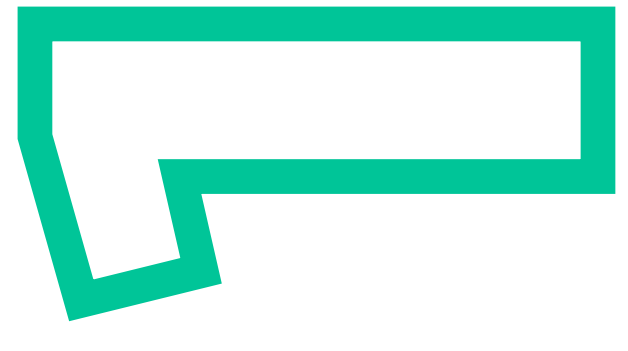

\section{PROCESSO DE} LAMINAÇÃO A FRIO

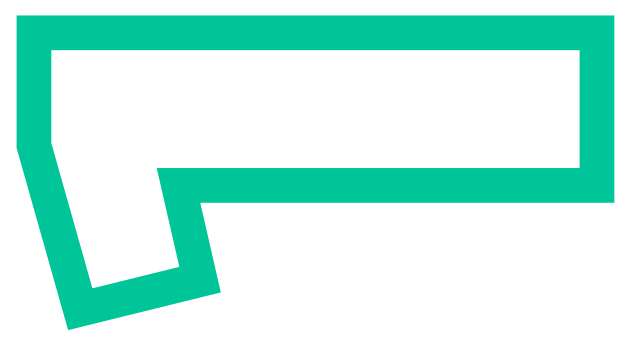

\section{Fala sobre:}

_ Introdução

_ Laminadores

_ Tipos de cilindros de laminação

_ Emulsão de óleo

_ Processo de laminação a frio

_ Referências Bibliográficas

_ Exercícios resolvidos 
Os processos de conformação plástica dos metais permitem a obtenção de peças em estado sólido, com características controladas, através da aplicação de esforços mecânicos cujo volume se mantem constante.

\section{LAMINAÇÃO A FRIO}

A laminação a frio é um processo de deformação feito a frio, ou seja, em temperaturas posicionadas bem abaixo da temperatura de recristalização dos aços. Lembrando que, para cada passe (redução na espessura) dado às chapas de aço, ocorre um incremento na tensão residual do mesmo, até ocorrer o que chamamos de encruamento. Estes passes, feitos a frio, não podem exceder de um determinado valor percentual devido às tensões aplicadas nos cilindros que são funções desta taxa de redução dos materiais.

A laminação a frio é um processo que é realizado após o material ter sido submetido a decapagem contínua para retirada dos óxidos gerados durante o processo de laminação a quente.

Esse processo tem a finalidade única e exclusivamente de deixar o material na espessura final do produto, conforme a solicitação dos clientes finais. A peça inicial para o processamento da laminação a frio, pode-se dizer que é um produto semiacabado - chapa, oriundo do processo de laminação a quente.
Como a temperatura de trabalho, embora ocorra aquecimento, na ordem de $100^{\circ} \mathrm{C}$, devido ao forte atrito desenvolvido entre o material e os cilindros de trabalho, pode-se dizer que o processamento é feito na temperatura ambiente.

São necessárias forças de compressão elevadas para este processo. Dessa forma, não se consegue altas taxas de redução de espessura. A redução total do material, é o somatório das reduções de cada passe dado em cada cadeira de laminação.

A laminação a frio é utilizada, portanto, nas operações finais (de acabamento), quando as especificações do produto indicam a necessidade de acabamento superficial superior obtido com cilindros mais lisos e na ausência de aquecimento, o que evita a formação de cascas de óxidos e de estrutura do metal encruada com ou sem recozimento final.

Este processo de conformação, além de reduzir a espessura da chapa, imprime nesse produto um acabamento superficial cuja rugosidade é função do acabamento dos cilindros de trabalho na última cadeira de laminação; confere nos produtos melhores propriedades mecânicas.

A maior parcela da energia despendida no trabalho a frio é dissipada na forma de calor, contudo, uma porção finita dessa energia é armazenada no material como energia de deformação, associada com os diversos defeitos cristalinos gerados pela deformação plástica.

Para se ter um acabamento superficial 
no produto final, com melhor controle, deve-se lançar mão dos laminadores de encruamento. Este processo de laminação é realizado após a etapa de recozimento e antes dos processos de tratamentos superficiais da chapa fina (estanhamento eletrolítico e galvanização eletrolítica e a banho a quente). Nestes laminadores, a taxa de redução a frio fica posicionada entre $1,0 \%$ e $2.0 \%$. Com este nível de redução, a espessura praticamente se mantém. No caso de dureza do material, ocorre um pequeno aumento. Esses laminadores, também conhecidos como Skin pass, têm a principal finalidade de eliminar o defeito conhecido como Linhas de Luders que são marcas indesejáveis que se desenvolvem na superfície das chapas durante os processos posteriores de estampagem.

A seguir apresenta-se uma sequência típica de operações: após a laminação a quente, as chapas semiacabadas na forma de bobinas são desenroladas, decapadas nas decapagens ácidas de processamento contínuo e, em seguida, são secadas, oleadas e enroladas novamente. O óleo tem a finalidade diminuir o atrito desenvolvido entre cilindro de trabalho e chapa, de forma a permitir o processo de laminação a frio. Ele atua, também, como protetor contra a corrosão (oxidação) até seu processamento no processo de recozimento, tanto em caixa como o processo continuo. Vale destacar que este óleo é eliminado durante estes processos supra citado.

No processo conduzido num trem de laminação contínuo, com três a seis gaiolas (cadeiras) de laminadores quádruo, cada gaiola promove uma determinada taxa de redução de espessura. As velocidades dos cilindros das diversas gaiolas são sincronizadas de modo a manter a chapa sob tensão desde a desenroladeira, onde é feita a alimentação do material no processo, passando pelas diversas gaiolas, até atingir a enroladeira, onde é realizado o rebobinamento do material já laminado.

A medida que se aumenta a força de tração entre as cadeiras, consequentemente, menor é a força de compressão a ser aplicada entre os cilindros de laminação. Os níveis dessas forças crescem à medida que a peça passa pelas diversas gaiolas, devido ao encruamento (endurecimento) do material.

A programação de redução em cada estágio deve ser estabelecida (programada) de modo que as cargas nos laminadores sejam uniformemente distribuídas e aproveite a capacidade de cada estágio, capacidade esta que depende de diversos fatores, tais como: projeto do laminador, potência disponível, largura do material, taxa de redução da chapa, condições de lubrificação entre cilindro e chapa, resistência do material, planicidade da chapa, acabamento das superfícies da chapa-cilindros e diâmetros dos cilindros.

Normalmente, é na última cadeira de laminação, que é impresso na chapa uma pequena deformação plástica para conferir ao produto um melhor acabamento, planicidade e tolerância dimensional na espessura. Vale destacar que é na última cadeira de laminação que é impresso a rugosidade do material. 
Num trem de laminação com laminadores quádruos, comumente promove-se a redução de $25 \%$ a $45 \%$ em cada estágio inicial e intermediário e cerca de 10\% a 30\% no estágio final; a redução total, dependendo do produto, pode atingir algo da ordem de $90 \%$. Essa redução provoca a elevação da temperatura da peça e dos cilindros, podendo chegar a aproximadamente $100^{\circ} \mathrm{C}$.

No caso de laminação de não ferrosos, de alta velocidade, esta temperatura pode atingir valores da ordem de $200^{\circ} \mathrm{C}$. O calor gerado é dissipado com auxílio de um jato de uma emulsão composta de óleo solúvel-água, dirigido diretamente às superfícies dos cilindros e das chapas, para manter as temperaturas nesses níveis máximos indicados.

A disposição mais comum de cilindros na gaiola é nos laminadores tipo quádruo. Os cilindros de trabalho são de diâmetros menores - de modo a reduzir a pressão de laminação e os cilindros de encosto, os quais inibem a flexão dos cilindros de trabalho. É importante salientar que os cilindros são dotados de uma leve variação de diâmetros ao longo de seu corpo, o que chamamos de coroa, que pode ser positiva ou negativa, dependendo de sua aplicação. Esta referida coroa tem uma precisão da ordem de microns. É obtida durante o processo de retífica do cilindro.

Com relação ao acabamento superficial dos produtos laminados a frio, ele é diretamente dependente do acabamento superficial dos cilindros. Pode variar de superfícies brilhantes, obtida com cilindros polidos, a superfícies foscas, obtida com cilindros que sofreram tratamento superficial com jato de areia. Neste caso, o resultado é um acabamento fosco.

\section{ÓLEO EMULSIVO}

É o principal insumo utilizado no processo de laminação a frio. Ele tem características especificas, apresentadas a seguir:

_ refrigeração dos cilindros;

_ lubrificação entre chapa e cilindro;

_ limpeza contínua do equipamento como um todo;

- melhoria da velocidade do laminador devido a diminuição do atrito, o que evidentemente, aumenta a produtividade;

- melhoria da qualidade de superfície da chapa e do cilindro.

$\mathrm{Na}$ laminação de chapas a frio, além da concepção do equipamento na qual engloba um laminador, é imprescindível e necessário a utilização de insumos, para que torne o processo estável e que não tenha problemas no decorrer do processo de forma a não comprometer a qualidade.

A maior parte do óleo emulsivo (também conhecido como emulsão) é direcionada, sempre, diretamente nos cilindros. Caso haja uma variação térmica brusca, pode favorecer o aparecimento de trincas ou até a quebra do cilindro devido a dilatação, provocada pelo calor, entre a camada tratada e o núcleo do cilindro ocasionado pela diferença de dureza entre as camadas do cilindro. 
A solução (emulsão) do líquido utilizado na laminação tem base mineral e contém aproximadamente 3\% de óleo miscível na base água.

\section{CILINDROS}

Os cilindros de laminação, principalmente aqueles da laminação a frio, são considerados a terceira fonte de custos em uma usina siderúrgica. Esta situação econômica, aliada ao fato de que estas ferramentas respondem diretamente pela precisão da forma e da qualidade superficial dos produtos, torna imprescindível uma boa seleção desses equipamentos.

A escolha correta dos cilindros, portanto, simultaneamente, melhora o faturamento da fábrica, como também propicia uma diminuição de seus gastos.

No que diz respeito a desenvolvimento de cilindros de laminação, é importante citar que sempre despertaram interesse nas empresas de grande porte. Atualmente estão sendo feitos muitos estudos para que essa ferramenta ofereça um desempenho cada vez melhor, tanto em lamina- dores contínuos quanto em laminadores reversíveis.

É importante comentar as particularidades, muito importantes, no processo de laminação:

1. Quando na sua substituição existe a necessidade de interromper o processo produtivo para que eles sejam substituídos, afeta diretamente a produtividade do laminador, em outras palavras, afeta a linha de produção como um todo. Pode-se citar que, em média, são aproximadamente 1 troca por turno de 8 horas;

2. Os cilindros de trabalho fazem contato direto com o aço laminado, consequentemente, a qualidade superficial dos mesmos é de suma importância para a qualidade superficial da chapa laminada;

3. E por último, como já foi dito, é um insumo de elevado custo no processo de laminação.

A figura 19 apresenta uma visão de um conjunto de cilindros de trabalho e de encosto. Nesta figura, pode-se visualizar também o corpo, o pescoço e o trevo dos cilindros.

Figura 19 - Ilustração de um conjunto de cilindros de trabalho e encosto

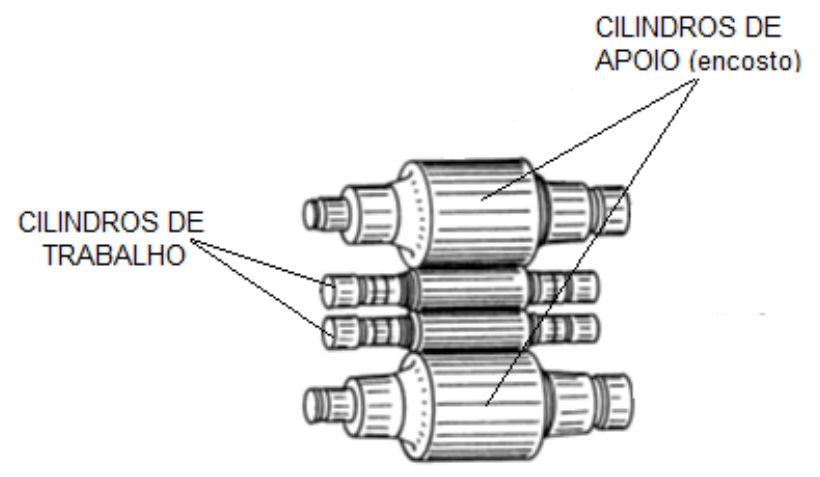

Fonte: autores 
A figura 20 apresenta um cilindro mostrando suas partes principais (corpo, pescoço e trevo).

Figura 20 - exemplo de um cilindro mostrando suas partes principais (corpo, pescoço e trevo)

Fonte: autores

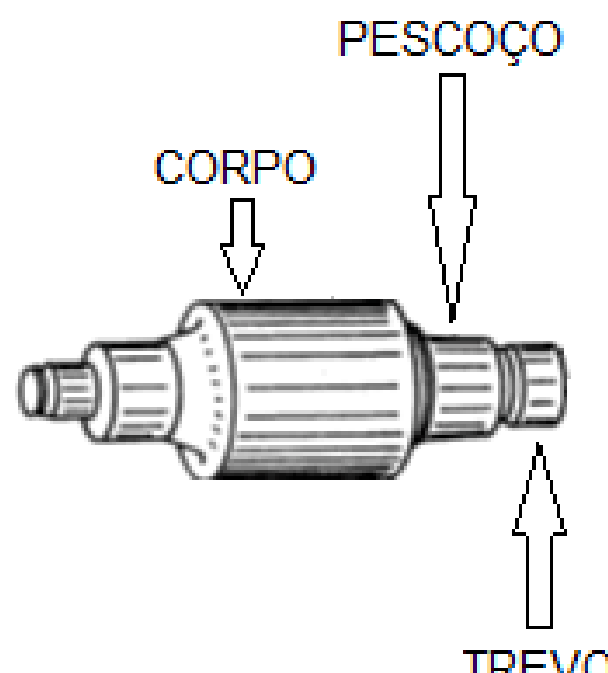

Os cilindros de trabalho sofrem deformações mecânicas importantes que merecem ser destacadas. A flexão ocorre devido às altas cargas de laminação aplicadas nas extremidades dos cilindros de encosto que por sua vez são transmitidas para os cilindros de trabalho. Atualmente, a maioria dos laminadores possuem sistemas de contra flexão, chamada de work roll bending. Este dispositivo de controle tende a reduzir a flexão dos cilindros, evitando assim defeitos tipo ondulados, tanto central quanto lateral, que podem se desenvolver tanto nas bordas quanto no centro da chapa.

Os cilindros de trabalho estão sujeitos também a um outro problema chamado achatamento - palavra oriundo do inglês flattening. É uma deformação elástica dos cilindros devido à pressão envolvida entre as regiões de contato entre os dois cilindros e entre cilindro de trabalho-chapa.

\section{REFERÊNCIAS}

[1]. Anais do XXXVI Seminário de Laminação - Processos e Produtos Laminados e Revestidos, Associação Brasileira de Metalurgia e Materiais, Belo Horizonte MG, 22 a 24 de Setembro de 1999.

[2]. BUTTON, S. T. Apostila de conformação plástica dos metais. Campinas: Editora da Unicamp, 2000.

[3]. CALLISTER JR., W. D. Ciência de engenharia de materiais: uma introdução. Rio de Janeiro: LTC, 2002. 2. ASM International - Metals HandBook - Heat Treating. Vol. 4. Detroit: ASM, 1991. 
[4]. CENTRO DE INFORMAÇÃO METAL MECÂNICA - CIMM. Disponível em: www. cimm.com.br. Acesso em 20 de março de 2015.

[5]. CHIAVERINI, V. Tecnologia mecânica. v. I. 2. ed. São Paulo: Mc Graw-Hill, 1986.

[6]. DIETER, G. E. Metalurgia mecânica. Parte IV. Rio de Janeiro: Guanabara Dois, 1981.

[7]. GARCIA, A., SPIM, J. A.; SANTOS, C. A. Ensaios de materiais. Rio de Janeiro: Editora Livros Técnicos e Científicos S. A., 2000.

[8]. GRUNING, K. Técnicas de conformação, polígono da técnica mecânica. São Paulo: Editora Polígono, 1973.

[9]. HELMAN, H.; CETLIN, P. R. Fundamentos da conformação mecânica dos metais. Rio de Janeiro: Guanabara Dois, 1983.

\section{EXERCÍCIOS}

1. Fale, resumidamente, sobre o processo de laminação a frio;

2. O que significa encruamento?

3. Qual as finalidades da laminação a frio?

4. Quais as taxas de redução nos laminadores de encruamento?

5. Como é feita a programação de redução em cada estágio de laminação?

6. Qual é o principal insumo utilizado na laminação a frio?

7. Qual a relação entre as forças de tração e compressão na laminação a frio?

8. Qual a finalidade do equipamento work roll bending?

9. Porque é importante uma boa seleção dos cilindros de laminação?

10. Como é denominada a deformação elástica dos cilindros devido à pressão envolvida entre as regiões de contato entre os dois cilindros e entre cilindro de trabalho-chapa?

\section{RESOLUÇÃO DOS EXERCICIOS}

1. A laminação a frio, é um processo de deformação feito a frio, ou seja, em temperaturas posicionadas bem abaixo da temperatura de recristalização dos aços. Lembrando que para cada passe (redução na espessura) dado às chapas de aço, ocorre um incremento na tensão 
residual do mesmo, até ocorrer o que chamamos de encruamento.

2. O encruamento é um endurecimento do aço em decorrência do aumento da densidade de discordâncias devido a intensa deformação a frio.

3. Este processo de conformação, além de reduzir a espessura da chapa, ele imprime nesse produto, um acabamento superficial cuja rugosidade é função do acabamento dos cilindros de trabalho na última cadeira de laminação. Confere nos produtos melhores propriedades mecânicas.

4. Variam de 1,0\% a 2,0\% de redução. É apenas um passe de superficie com a finalidade principal de eliminar o patamar de escoamento dos aços recozidos.

5. A programação de redução em cada estágio deve ser estabelecida (programada) de modo que as cargas nos laminadores sejam uniformemente distribuídas e aproveite a capacidade de cada estágio, capacidade esta que depende de diversos fatores, tais como: projeto do laminador, potência disponível, largura do material, taxa de redução da chapa, condições de lubrificação entre cilindro e chapa, resistência do material, planicidade da chapa, acabamento das superfícies da chapa-cilindros e diâmetros dos cilindros.

6. É o óleo emulsivo (emulsão). Ele tem características específicas, apresentadas a seguir: * refrigeração dos cilindros; *lubrificação entre chapa e cilindro; *limpeza contínua do equipamento como um todo; *melhoria da velocidade do laminador devido a diminuição do atrito, o que evidentemente, aumenta a produtividade; *melhoria da qualidade de superfície da chapa e do cilindro.

7. A medida que se aumenta a força de tração entre as cadeiras, consequentemente, menor é a força de compressão a ser aplicada entre os cilindros de laminação. Os níveis dessas forças crescem à medida que a peça passa pelas diversas gaiolas, devido ao encruamento (endurecimento) do material.

8. Este dispositivo de controle tende a reduzir a flexão dos cilindros, evitando assim defeitos tipo ondulados, tanto central quanto lateral, que podem se desenvolver tanto nas bordas quanto no centro da chapa.

9. Os cilindros de laminação, principalmente aqueles da laminação a frio, são considerados a terceira fonte de custos em uma usina siderúrgica. Esta situação econômica aliada ao fato de que estas ferramentas respondem diretamente pela precisão da forma e da qualidade superficial dos produtos, torna imprescindível uma boa seleção desses equipamentos.

10. É denominada de flattening. Os cilindros de trabalho estão sujeitos a este tipo de defeito. É um achatamento, que é a tradução do inglês (flattening). É uma deformação elástica dos cilindros devido à pressão envolvida entre as regiões de contato entre os dois cilindros e entre cilindro de trabalho-chapa. 


\section{PROCESSO DE RECOZIMENTO}

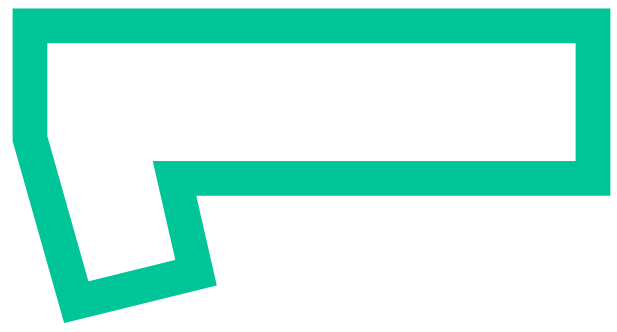

\section{Fala sobre:}

_ Introdução

_ Processo de recozimento

_ Definições de recozimento

_ Variáveis que influenciam

_ Dicas sobre qualidade

_ Referências Bibliográficas

_ Exercícios resolvidos 
Os objetivos principais do recozimento são: remover tensões internas, diminuir a dureza, melhorar a ductilidade, ajustar o tamanho dos grãos, obter estruturas favoráveis para submeter o aço a processos posteriores e eliminar os efeitos de quaisquer tratamentos mecânicos anteriores.

\section{RECOZIMENTO}

O processo de laminação a frio dos aços, que tem como objetivo principal o ajuste da espessura final das chapas de aço, induz no material um aumento excessivo de sua resistência mecânica. Este incremento é devido, principalmente, ao aumento da densidade de defeitos em sua estrutura interna, o que vai depender da severidade de deformação.

Quanto maior for a redução a frio no material laminado, mais forte é a modificação da estrutura mecânica. Ocorre um alongamento dos grãos ferríticos na direção de laminação. Comprometendo seriamente a dureza e o limite de resistência, que ficam posicionados em valores elevados, tornando o aço muito quebradiço e impróprio para as aplicações de estampagem posteriores. Assim sendo, é necessário submeter o aço a um tratamento térmico para se aliviar as tensões internas e promover a formação de novos grãos, com a mesma composição e estrutura cristalina dos grãos originais, porém alongados e heterogêneos. Este processo é conhecido como recristalização. A este tratamento chamamos de recozimento.

Existem dois tipos diferentes de recozimento, que é o convencional (em caixa) ou contínuo (recozimento rápido), em que o processo é feito sem interrupção.

No caso dos aços com baixo teor de carbono laminados a frio, que foram submetidos a taxas elevadas de redução, o processo de recozimento subcrítico, em que a temperatura de início da transformação ferrítica/austenita, que é de aproximadamente $723^{\circ} \mathrm{C}$, é o mais adequado.

O processo de recozimento pode ser representado por um ciclo térmico tempo-temperatura. As principais variáveis que influenciam neste processo, no que diz respeito na qualidade superficial e de propriedades mecânicas, são: aquecimento, temperatura de encharque, tempo de encharque e resfriamento.

\section{AQUECIMENTO}

Durante esta fase, devem ser consideradas a velocidade e a temperatura máxima de aquecimento do metal. A velocidade de aquecimento é um fator importante a ser considerado, pois se o metal a ser aquecido apresentar uma elevada tensão interna e a velocidade de aquecimento for muito alta, este material pode apresentar defeitos superficiais e variações em suas características de estampabilidade, comprometendo, assim, sua qualidade.

No caso de aquecimento muito lento, o material fica propenso a apresentar um 
excessivo crescimento de grão, que nem sempre é desejável.

\section{TEMPERATURA DE AQUECIMENTO}

Outra variável importante a se considerar, também, é a temperatura de aquecimento. A escolha da temperatura ideal vai depender das propriedades mecânicas e estruturas finais desejadas para o material e também da sua composição química.

\section{TEMPO DE ENCHARQUE}

Após ser determinada a temperatura de aquecimento do material, o tempo de permanência nesta temperatura também é um fator que depende das propriedades mecânicas almejadas e estruturas finais desejadas para o material.

O tempo de encharque na temperatura desejada é o tempo necessário para que todo o material enfornado, atinja, de forma homogênea, a temperatura desejada, ou seja, aquela programada.

\section{RESFRIAMENTO}

O resfriamento é, também, uma variável muito importante. A velocidade de resfriamento determina efetivamente a estrutura e, consequentemente, as propriedades finais do material.

Quanto mais lento for o resfriamento, mais macio será o material recozido, o que implica em melhores qualidades para estampagem no cliente final. Dentro do ciclo térmico, esta é a etapa mais demorada em todo o processo.

Os ambientes usuais de resfriamento são: o próprio forno ao ser desligado, naturalmente com o ar atmosférico, com ar forçado através de resfriadores e resfriamento com spray de água. Sendo que cada uma destas formas de resfriamento propiciam diferentes velocidades.

$\mathrm{Na}$ escolha do ambiente de resfriamento, os principais fatores a serem considerados são: a estrutura final desejada e produtividade que se deseja alcançar.

O meio de resfriamento mais brando é ao ambiente do próprio forno. Em seguida, vem $\mathrm{o}$ ar naturalmente e finalmente $\mathrm{o}$ spray com água.

\section{DEFINIÇÕES DOS \\ DIFERENTES TIPOS DE RECOZIMENTOS}

\section{Recozimento azul}

É um recozimento realizado em condições tais que se forme na superfície metálica uma camada de óxido uniforme e aderente, de cor azulada.

\section{Recozimento brilhante}

É um recozimento realizado em condições tais que tende a eliminar a oxidação da superfície metálica.

\section{Recozimento ferrítico}

É um recozimento aplicado ao ferro fundido, destinado à obtenção de matriz ferrítica, 
também denominado ferritização. Utiliza-se com a finalidade de abaixar dureza.

\section{Recozimento intermediário}

É um recozimento realizado pela permanência em temperatura dentro da zona crítica. Utiliza-se para peças que necessitem ser usinadas, com remoção de cavacos, sob condições particulares.

\section{Recozimento isotérmico}

É um recozimento utilizado para peças que necessitem ser usinadas, e que, após a usinagem, devam sofrer tratamentos térmicos finais com distorções dimensionais mínimas e sempre repetitivas para grandes séries de produção.

\section{Recozimento para alívio de tensões}

É um recozimento subcrítico, visando à eliminação de tensões internas, sem modificação fundamental das propriedades existentes. É realizado após deformação a frio, tratamento térmico, soldagem e usinagem.

\section{Recozimento para crescimento} de grão

É um recozimento caracterizado por permanência em temperatura significativamente acima de zona crítica. O resfriamento deve ser lento até a temperatura ambiente. É destinado a produzir crescimento de grão.

\section{Recozimento para homogeneização}

É um recozimento caracterizado por um aquecimento até uma temperatura consideravelmente acima do ponto AC3 (diagrama Fe-C), longa permanência nessa temperatura e resfriamento adequado ao fim em vista, para eliminação de variações locais de composição do material.

Recozimento para recristalização

É um recozimento caracterizado pela permanência em temperatura dentro da faixa de recristalização, após deformação realizada abaixo dessa faixa. Utiliza-se para peças deformadas plasticamente a frio, com a finalidade de reduzirem seus limites de escoamento e de resistência.

\section{Recozimento para solubilização}

É um recozimento em consequência do qual um ou mais constituintes entram em solução, geralmente caracterizado por um resfriamento rápido destinado à retenção daqueles constituintes em solução sólida na temperatura ambiente. Também denominado solubilização, utiliza-se para peças que, durante as diversas etapas de produção, apresentam segregações dos elementos de liga da matriz básica.

\section{Recozimento pleno}

É um recozimento caracterizado por um resfriamento lento através da zona crítica, a partir da temperatura de austenitização (geralmente acima de Ac1 para aços hipoeutetóides e entre Ac3 e Acm para os hipereutetóides).

\section{Recristalização}

Os aços, na condição de laminado a frio, apresentam-se com elevada resistência 
mecânica em consequência de sua alta densidade de discordâncias, tanto no interior como também nos contornos dos grãos.

Após a laminação a frio deixa de existir a estrutura de grãos. Com base na termodinâmica, o aço se encontra numa situação instável, com alta energia armazenada, com tendência a uma situação estável de baixa energia. Esta energia armazenada atua como uma força motriz para o fenômeno de recristalização. Para o caso de recozimento de aços baixo carbono destinados a processos de estampagem, o tratamento é subcrítico, ou seja, é realizado abaixo da temperatura de transformação ferrita-austenita.

A figura 21 apresenta a influência da temperatura de recozimento nas propriedades mecânicas de um aço no estado "encruado".

Figura 21 - influência da temperatura de recozimento nas propriedades mecânicas de um aço no estado "encruado"

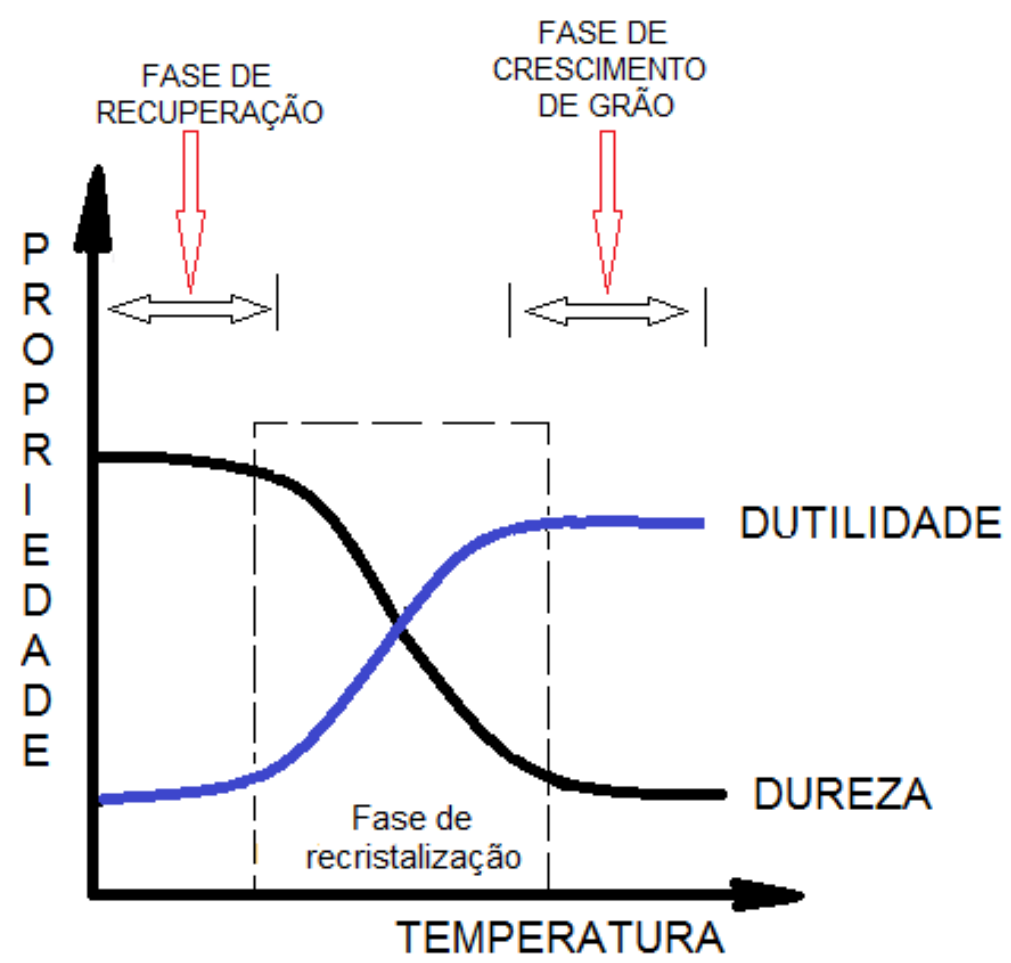

Fonte: autores

As propriedades descritas na figura 21 são com relação a dutilidade e a dureza. À medida que vai ocorrendo recuperação e recristalização, o material vai melhorando suas propriedades mecânicas, até o término do crescimento de grão que ocorre no final do processo de recozimento, ou melhor, no final da fase de encharque.
É usual referir-se a uma temperatura de recristalização de um metal, para designar a temperatura na qual o metal com um dado grau de encruamento, se recristalizará completamente após um período determinado de tempo, que é normalmente 1 hora. O processo de recristalização é muito mais sensível à variações de temperatura que do tempo. 
Além da temperatura e do tempo, vários outros fatores exercem influência sobre o processo. Dentre eles, podemos destacar o grau de encruamento, os elementos de liga e o tamanho de grão inicial.

A temperatura de recristalização diminui à medida que o grau de encruamento aumenta. Isto se deve ao fato de que a energia armazenada no aço aumenta com o encruamento.

A pureza do metal é outro fator relevante no processo de recristalização. O ferro é um exemplo típico. Enquanto que o ferro eletrolítico se recristaliza a aproximadamente $400^{\circ} \mathrm{C}$, a presença de pequenos teores de carbono, de fósforo, de silício e de nitrogênio, elevam a temperatura para acima de $540^{\circ} \mathrm{C}$.

Quanto menor o tamanho do grão inicial, maior será a área total dos contornos de grão em um dado volume de metal, o que propicia uma maior velocidade de nucleação para a recristalização. Isto resulta numa granulação recristalizada menor.

Após terminada a recristalização, se a temperatura for mantida, haverá uma lenta migração dos contornos de alguns grãos, produzindo crescimento uniforme destes grãos às custas do desaparecimento gradual de grãos menores. Este fenômeno é conhecido como crescimento de grão.

\section{Recozimento convencional em caixa}

Este é um processo muito antigo e bastante utilizado por grandes empresas produtoras de aços, de baixo carbono, laminados e destinados a estampagem de um modo geral. Embora antigo, vai sempre existir devido ao material produzido ter excelentes características de estampabilidade, principalmente nos casos de estampagem profunda e extra profunda, o que não se consegue através do recozimento contínuo.

Normalmente, o processo de recozimento em caixa, algumas vezes chamado de convencional, é considerado um processo de baixa produtividade porque é realizado com o material em pilhas, geralmente de 3 a 4 bobinas, podendo variar para mais ou para menos, dependendo da dimensão (largura) das bobinas e dos tempos de recozimento muito longos. Entre uma carga e descarga, pode variar entre 5 e 7 dias, no caso dos fornos convencionais. Vale destacar que o processo de recozimento com os fornos de alta convecção, ocorre uma melhoria, de aproximadamente 30\% na produtividade, podendo ser ainda melhor em alguns casos. Outro detalhe importante a comentar é que o gradiente térmico é muito grande, ou seja, a diferença entre o ponto mais quente (hot spot) e o ponto mais frio (cold spot) ao longo das bobinas empilhadas é muito grande.

O gás desoxidante, que basicamente é formado por uma atmosfera de gás HN (Hidrogênio 6\% + Nitrogênio 94\%), circulando sobre as bordas das bobinas, através dos convectores, levam o calor até as bordas de cada espira e, por condução, o calor é transmitido até atingir a parte mais fria da bobina, que é chamado de cold spot. 
O tratamento térmico é realizado nas bobinas de aço laminadas que se encontram dentro de uma proteção (abafador), separando as mesmas do produto da combustão. O abafador é pressurizado com uma atmosfera de gás desoxidante, que tem como finalidade proteger as bobinas quanto à oxidação. Os abafadores estão em contato com o produto da combustão vindo dos queimadores e transmite o calor para a carga, obtendo-se então a elevação da temperatura nas bobinas. Todo este processo tem como objetivo a obtenção do produto final com uma dureza de acordo com as necessidades do cliente e com uma superfície totalmente limpa. A transferência de calor para as bobinas ocorre por convecção. A transmissão do calor é mais rápida de borda a borda do que do diâmetro externo para diâmetro interno da bobina, isto é, devido à condutividade equivalente radial ser, em média, quatro vezes menor do que a condutividade verdadeira do metal.

O gás desoxidante, circulando sobre as bordas das bobinas através das placas de convecção ou convectores, aquecem as bordas de cada espira e, por condução, o calor é transmitido até atingir a parte mais fria da bobina (cold spot), distribuindo o calor entre cada bobina através das placas de convecção e retornando pelo eixo interno das bobinas de volta à ventoinha (ventilador da base). É sabido que a variação de temperatura no centro de qualquer bobina depende basicamente da sua largura e peso. Estas duas variáveis podem ser relacionadas com a quantidade de calor em kcal necessária para elevar a temperatura de um determinado peso em aço.

A conservação do sistema de convecção é de fundamental importância para que se tenha um adequado processo de aquecimento, assim como o diâmetro interno das bobinas por onde os gases oxidantes retornam à base, formando, assim, o processo de convecção. Vale salientar que, quanto menor o diâmetro interno das bobinas, menor a eficiência da convecção e incide adversamente no tempo de recozimento.

É importante salientar que, atualmente, algumas empresas já utilizam os chamados fornos de alta convecção, nos quais são utilizados, como gás desoxidante, o hidrogênio praticamente puro. Nestes equipamentos, os tempos de aquecimento, de encharque e de resfriamento, ou seja, os tempos totais de recozimento, são, praticamente, a metade quando comparado com os fornos convencionais. Devido ao menor tempo, consegue-se uma melhor produtividade, aliada a uma melhor qualidade no produto final, considerando propriedades mecânicas e limpeza superficial. Outro detalhe importante, que vale comentar, é que estes fornos funcionam totalmente automatizados, para implementação do ciclo térmico ao longo da carga através de controladores lógicos programáveis (CLP's).

Os fornos convencionais são de tubos radiantes ou de chama direta. A tabela I apresenta uma comparação entre estes dois tipos de fornos de recozimento convencional (tubo radiante e chama direta). 
Tecnologia siderúrgica

Tabela 1 - Comparação entre os fornos de recozimento convencional de tubo radiante e de chama direta

\begin{tabular}{ccc} 
ITENS ANALISADOS & TUBO RADIANTE & CHAMA DIRETA \\
Rendimento térmico & Menor & Maior \\
\hline Qualidade de superfície & Indiferente & Indiferente \\
\hline Qualidade de propriedade mecânica & Maior & Menor \\
\hline Vida útil do abafador & Maior & Menor \\
\hline
\end{tabular}

Fonte: autores

Um forno típico, composto de tubos radiantes, os quais são fabricados normalmente de aço inoxidável centrifugado. As bobinas são empilhadas e isoladas umas das outras por separadores ou convectores.

A transmissão do calor do forno para o abafador é feita através da convecção e da radiação. Sendo que, dentro do abafador, ocorre os três tipos de transmissão do calor, ou seja, além da convecção e radiação, ocorre também a condução, através das espiras das bobinas. A figura 22 apresenta um modelo de como ocorre o mecanismo de transmissão do calor durante o processo de recozimento.

Figura 22 - ilustração de como se processa o mecanismo de transmissão do calor durante o processo de recozimento

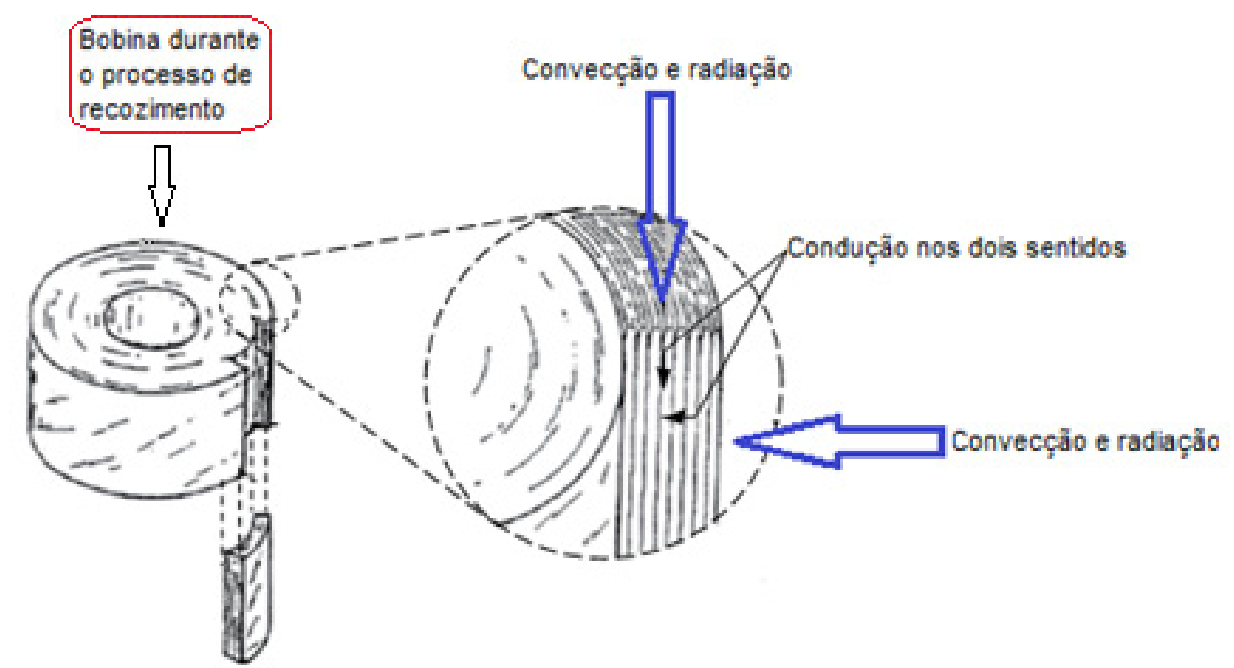

Fonte: autores

É importante destacar que existem fornos dotados de um sistema de recuperação do calor, que propicia uma redução no consumo de energia através de pré-aquecimento do ar de combustão. A figura 23 apresenta uma visão geral de um forno tipo campânula, onde pode-se visualizar o abafador, os convectores, o termopar e a ventoinha da base. 
Figura 23 - visão geral de um forno tipo campânula, onde pode-se visualizar o abafador, os convectores, o termopar e a ventoinha da base

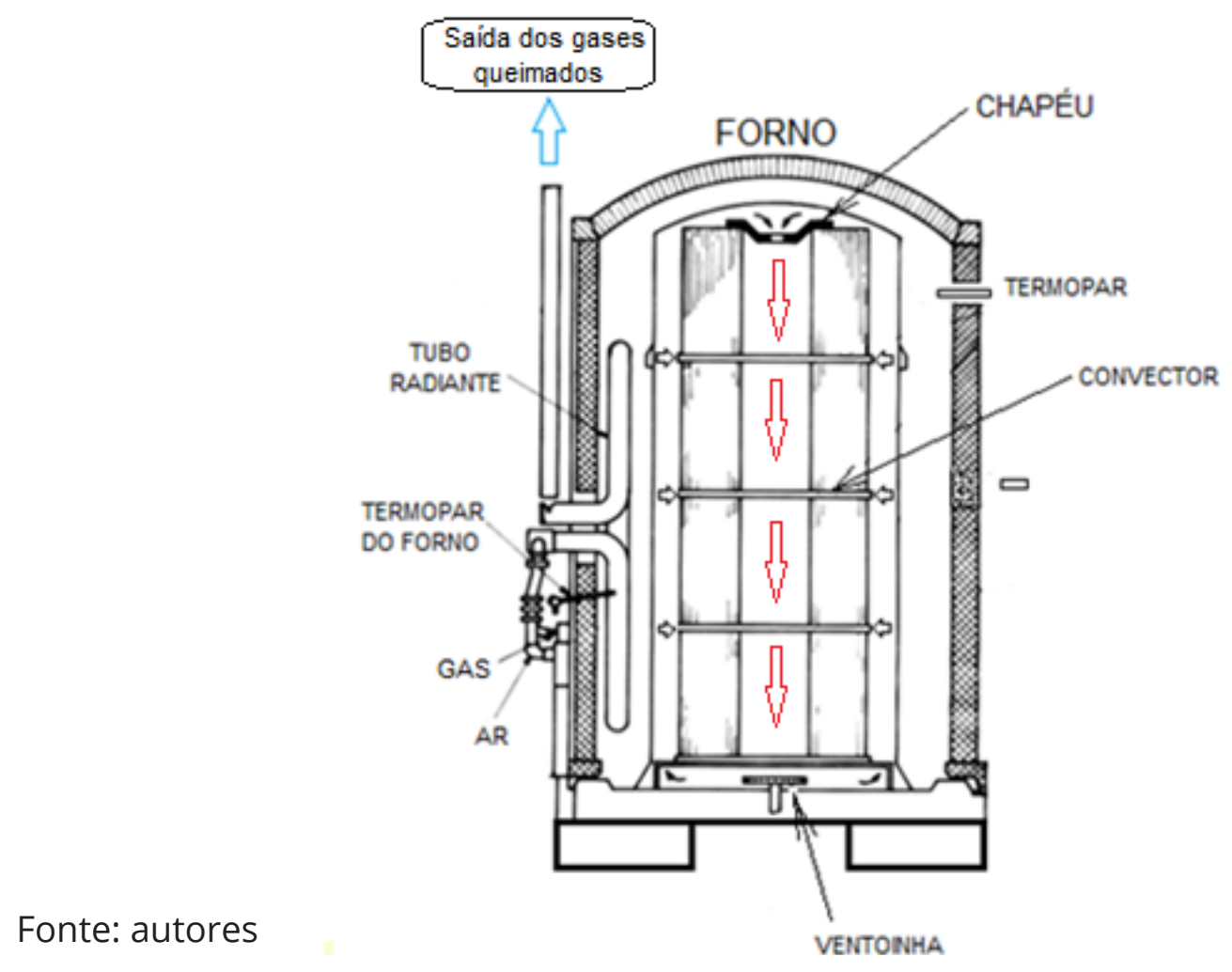

\section{FORNOS DE ALTA CONVECCÃO}

Com relação aos fornos de alta convecção, afirma-se que são dotados com atmosfera de até $100 \%$ de hidrogênio. Neste caso, ocorre um aumento significativo nos coeficientes de transmissão de calor por convecção, ou seja, o coeficiente do gás H2 é aproximadamente igual a 1,65 HN. Isto é devido as propriedades físicas do elemento hidrogênio, tais como: sua densidade e viscosidade.

A diferença deste forno em comparação com o forno convencional está posicionada principalmente com relação a qualidade e produtividade.

No caso do hidrogênio puro, a condutividade efetiva da bobina é muito maior. A condutividade radial com o $\mathrm{H} 2$ é de aproximadamente 10 vezes, quando na utilização do gás HN, o que proporciona uma menor diferença de temperatura entre os vários pontos da bobina.

Os fornos são dotados de equipamentos para medição contínua do teor de oxigênio nos gases de proteção, o que é essencial para a questão de segurança pessoal e do equipamento, uma vez sabendo que o gás H2 é um combustível em potencial. O teor máximo de oxigênio admissível dentro do forno é de $1 \%$ na composição do gás.

Este processo apresenta as seguintes vantagens:

1 - Menores ciclos de recozimento

Proporciona aumento da produtividade 
devido ao tempo menor das fases de aquecimento e de resfriamento;

2 - Uniformidade de temperatura

Considerando uma mesma carga e a mesma temperatura da base, a diferença de temperatura entre a primeira espira e o núcleo da bobina é de aproximadamente $160^{\circ} \mathrm{C}$, para o forno convencional com atmosfera de $\mathrm{HN}$, e de aproximadamente $70^{\circ} \mathrm{C}$, para o processo de alta convecção;

3 - Melhoria significativa da limpeza de superfície

Sendo altamente redutor, praticamente não existe oxidação superficial, ocorrendo significativa melhoria na qualidade de superfície;
4 - Menor consumo de energia

Os ciclos térmicos são aproximadamente metade de tempo em comparação com o processo convencional com atmosfera de HN. Neste caso, o consumo específico de energia é substancialmente reduzido. Para cada forno é necessário duas bases de recozimento (no caso de forno convencional são quatro bases para cada forno).

A figura 24 é uma comparação dos perfis térmicos dos processos de alta convecção (hidrogênio puro) e fornos convencionais (atmosfera de HN). Na figura, está posicionado uma carga de 100 toneladas para ilustrar a aplicação do perfil térmico na carga.

Figura 24 - comparação entre os perfis térmicos dos processos de alta convecção (hidrogênio puro) e fornos convencionais (atmosfera de HN)

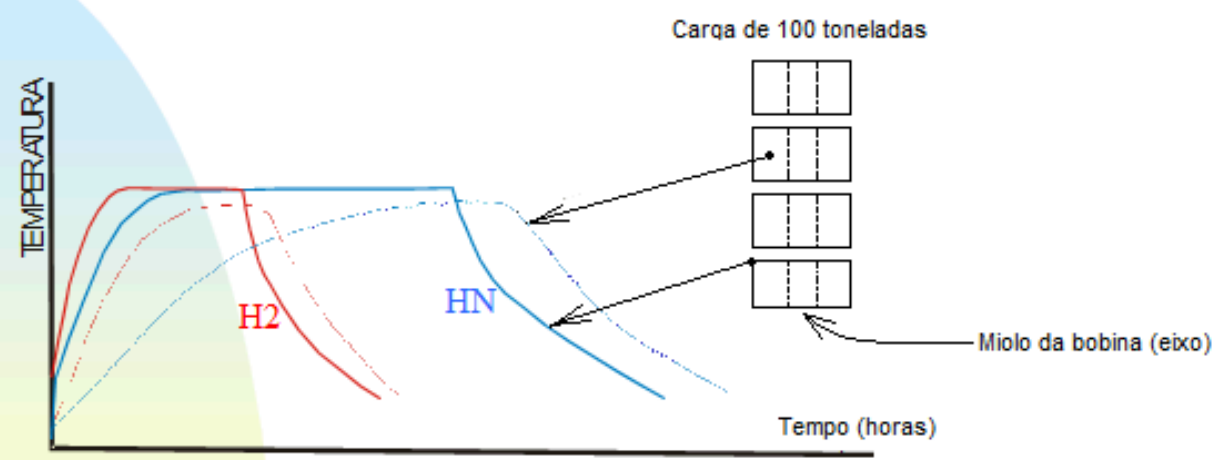

Fonte: autores

\section{EQUIPAMENTOS DE UM RECOZIMENTO DE BOBINAS}

A seguir são descritos os principais equipamentos que fazem parte de um sistema de recozimento em caixa ou campânula (Batch annealing). Dentre eles, podemos destacar: a base (onde são apoiado os fornos), a campânula protetora (abafador), o convector (separador das bobinas) e o resfriador (campânula de resfriamento). 


\section{Base}

É um suporte onde são apoiadas e empiIhadas as bobinas a serem recozidas. É constituída de uma carcaça metálica, revestida de material refratário (tijolos ou argamassa). Na sua parte central, sobre o refratário, está posicionado o difusor, dentro do qual está alojada a ventoinha, que é responsável pela circulação do gás de proteção ao longo da carga. A movimentação do gás no interior da câmara, que é a convecção forçada, propicia a transmissão do calor da parte central da bobina (miolo) para o exterior da bobina.

A figura 25 apresenta um exemplo típico de uma base de recozimento. São mostrados os detalhes do termopar, ventoinha, convector e uma bobina posicionada.

Figura 25 - exemplo típico de uma base de recozimento. São mostrados detalhes do termopar da base, ventoinha e uma bobina posicionada

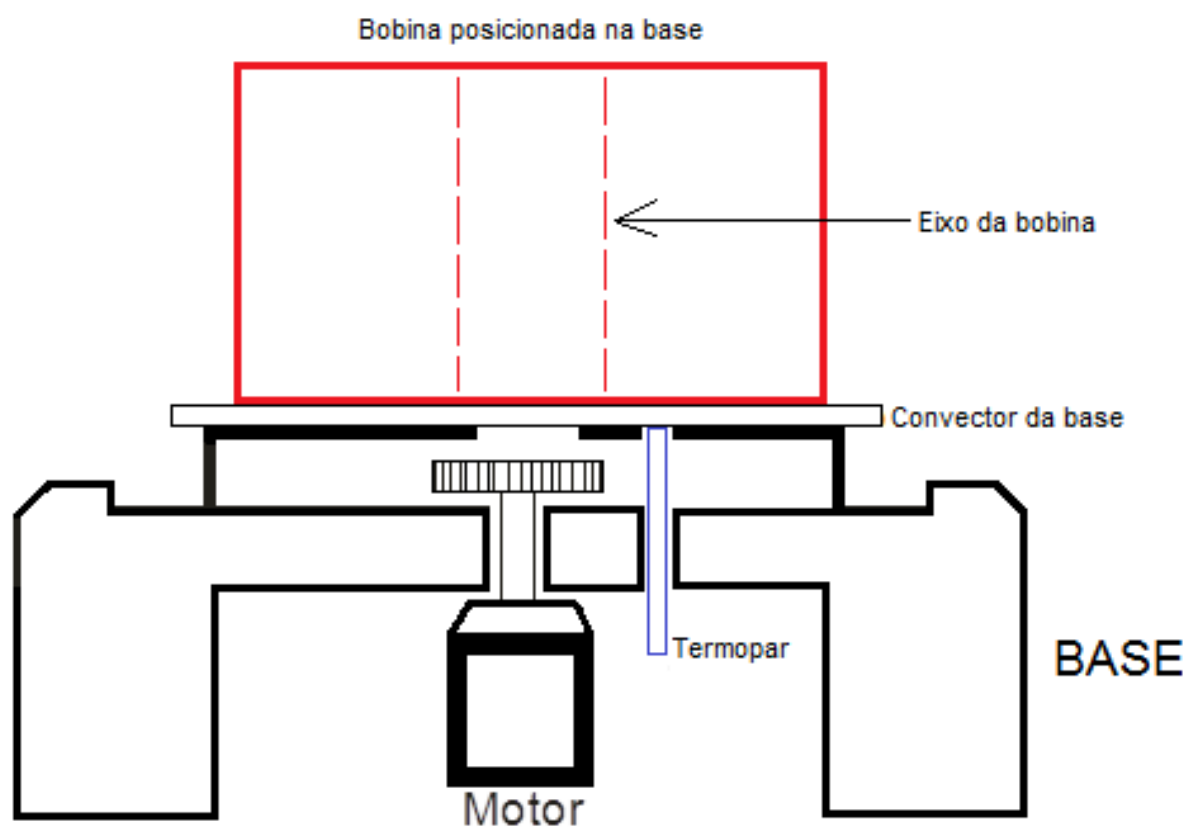

Fonte: autores

A selagem do contato entre base $e$ abafador é feita com borracha, areia ou manta de lã de vidro. A areia tem a vantagem de se poder utilizar abafadores com as abas empenadas. Por outro lado, exige um controle rigoroso da granulometria da areia, sob pena de perda de estanqueidade do sistema.

É importante salientar que o termopar da base tem que ter contato direto com o convector da base para garantir uma melhor homogeneidade de temperatura durante o processo de recozimento.

\section{Campânula protetora ou abafador}

Tem como finalidade principal fazer o isolamento entre o material a ser recozido e o meio ambiente (oxigênio do ar). São, normalmente, fabricados de aço inoxidável austenítico ou aço baixo carbono e podem ser lisos ou corrugados. É importante destacar que as paredes corrugadas 
aumentam a superfície externa dos abafadores e também permitem que se utilize um material com menor espessura devido a sua maior resistência. Os de aço inox são duradouros, em contrapartida são de alto custo. Cada caso deve ser analisado cuidadosamente antes da compra.

Durante o processo de recozimento a parede dos abafadores atingem temperaturas da ordem de $800^{\circ} \mathrm{C}$. Isto é um dos principais fatores que influenciam na vida útil destes equipamentos.

A figura 26 apresenta um modelo simples de um abafador que pode ser fabricado com aço ao carbono comum ou aço inoxidável.

Figura 26 - modelo ilustrativo de um abafador simples

Fonte: autores

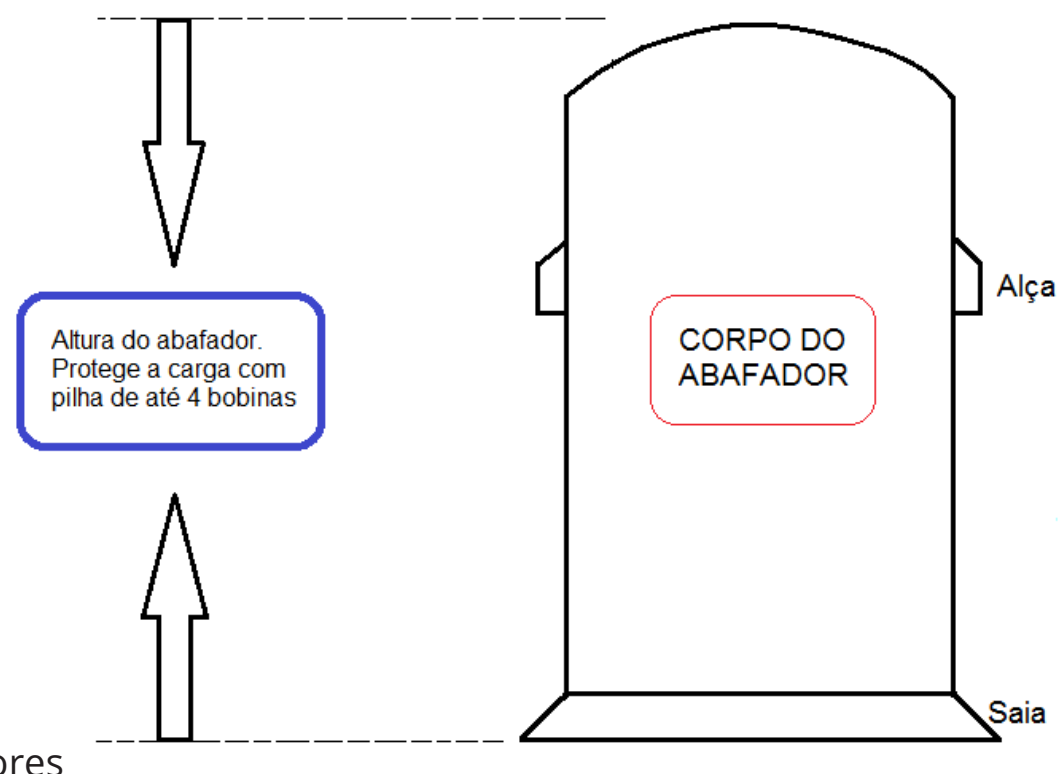

\section{Convector ou separador de bobinas}

São espaçadores colocados entre as bobinas que formam a carga para possibilitar a passagem do gás de proteção entre as bobinas empilhadas propiciando que o calor seja transportado do topo e da base das bobinas para a parte central.

A convecção forçada do gás de proteção depende fortemente dos convectores. Seu formato (desenho) também é muito importante no rendimento final do sistema.

\section{Resfriador ou campânula de resfriamento}

Uma grande parte do tempo total de processamento é gasto na etapa de resfriamento. O ideal é fazer a descarga do material em temperaturas abaixo de $100^{\circ} \mathrm{C}$.

Para acelerar a velocidade de resfriamento, são utilizados os resfriadores. Eles aspiram o ar atmosférico em torno dos abafadores.

\section{CICLO TÉRMICO}

O ciclo térmico é dividido em três partes principais: aquecimento, encharque e 
resfriamento. A figura 27 apresenta perfis térmicos em diferentes pontos ao longo das bobinas em recozimento. É um ciclo térmico intencionado à $580^{\circ} \mathrm{C}$ por 6 horas de encharque. São mostrados, na figura, as temperaturas mais frias, que são os "pontos frios" (cold spot), bem como as partes mais quentes, que são os "pontos quentes" (hot spot).

Vale lembrar que o ponto com mais alta temperatura $\left(650^{\circ} \mathrm{C}\right)$ está posicionado no topo da carga, que, na verdade, é o empiIhamento das bobinas para fazer o tratamento de recozimento.

Figura 27 - perfis térmicos em diferentes pontos ao longo das bobinas (carga) durante o processo de recozimento

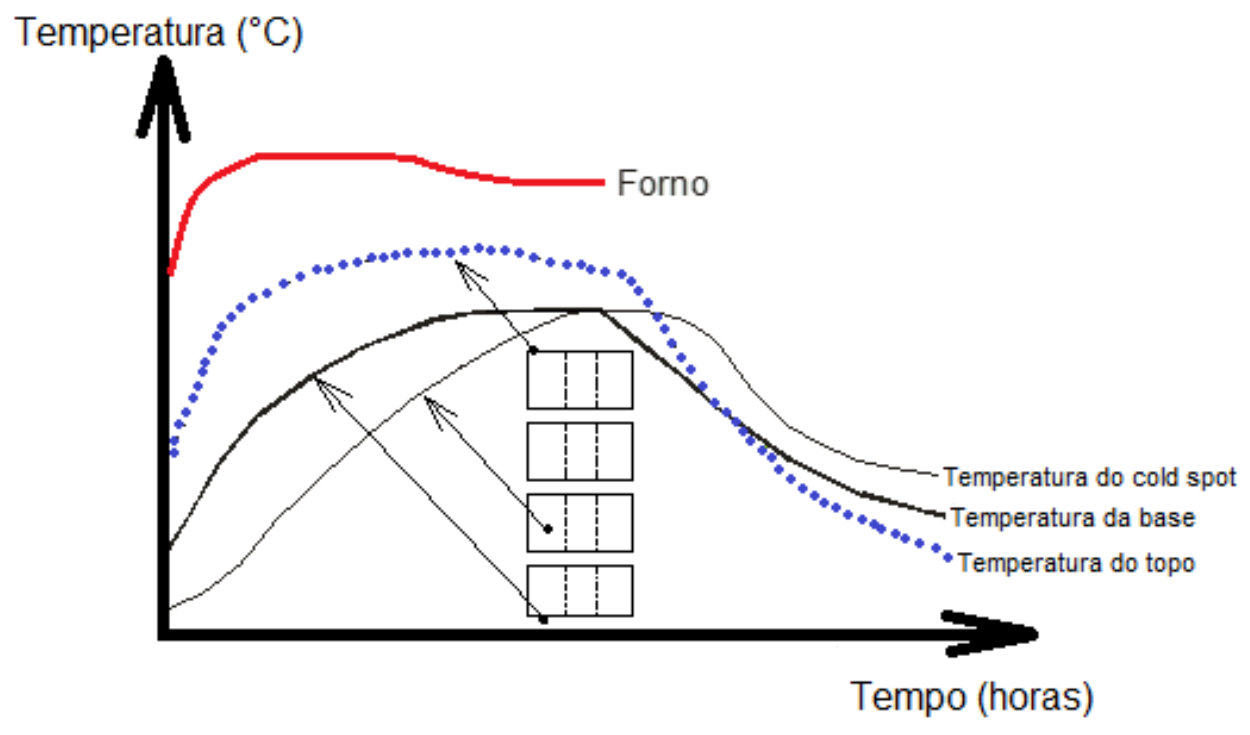

Fonte: autores

\section{PRINCIPAIS VARIÁVEIS NO PROCESSO DE RECOZIMENTO}

As principais variáveis que influenciam no processo de recozimento que influenciam nas propriedades mecânicas são:

_ composição química;

- temperatura de acabamento na laminação a quente;

_ temperatura de bobinamento na laminação a quente;

_ largura das bobinas;
_ espessura das chapas ou folhas;

_ variáveis de recozimento (aquecimento, encharque e resfriamento).

\section{RECOZIMENTO CONTÍNUO}

É um processo de tratamento térmico em que o próprio material é quem faz o perfil térmico, através de seu movimento no interior do forno de recozimento.

Normalmente as linhas de recozimento contínuo são divididas em 3 (três) partes principais: seção de entrada, seção de 
processo e seção de saída. A entrada é composta, basicamente, pelas desenroladeiras, máquina de solda, equipamentos de medição de espessura e a limpeza eletrolítica. O processo é realizado no forno de recozimento, normalmente vertical. A saída é composta pela inspeção e enroladeiras.

O forno é dividido em quatro seções principais: aquecimento, encharque, resfriamento lento e resfriamento rápido.

As temperaturas de cada seção do forno são mantidas numa pequena faixa de variação e a tira viaja numa velocidade praticamente constante, ao longo de todo o processo, desde a desenroladeira.
É importante destacar que, após a desenroladeira e antes da enroladeira, existem duas torres de acumulação de material de forma a permitir a troca da desenroladeira e da enroladeira sem comprometimento de todo o processo.

As diferenças marcantes com o processo convencional são: o volume de produção, a qualidade de superfície e a homogeneidade de propriedades mecânicas.

A figura 28 apresenta uma visão sucinta de uma linha de recozimento contínuo. Pode-se visualizar, na figura, as partes principais (desenroladeira, medidor de espessura, tanque de limpeza eletrolítica, tanque de lavagem, secagem, forno de recozimento continuo e enroladeira).

Figura 28 - visão sucinta de uma linha de recozimento contínuo

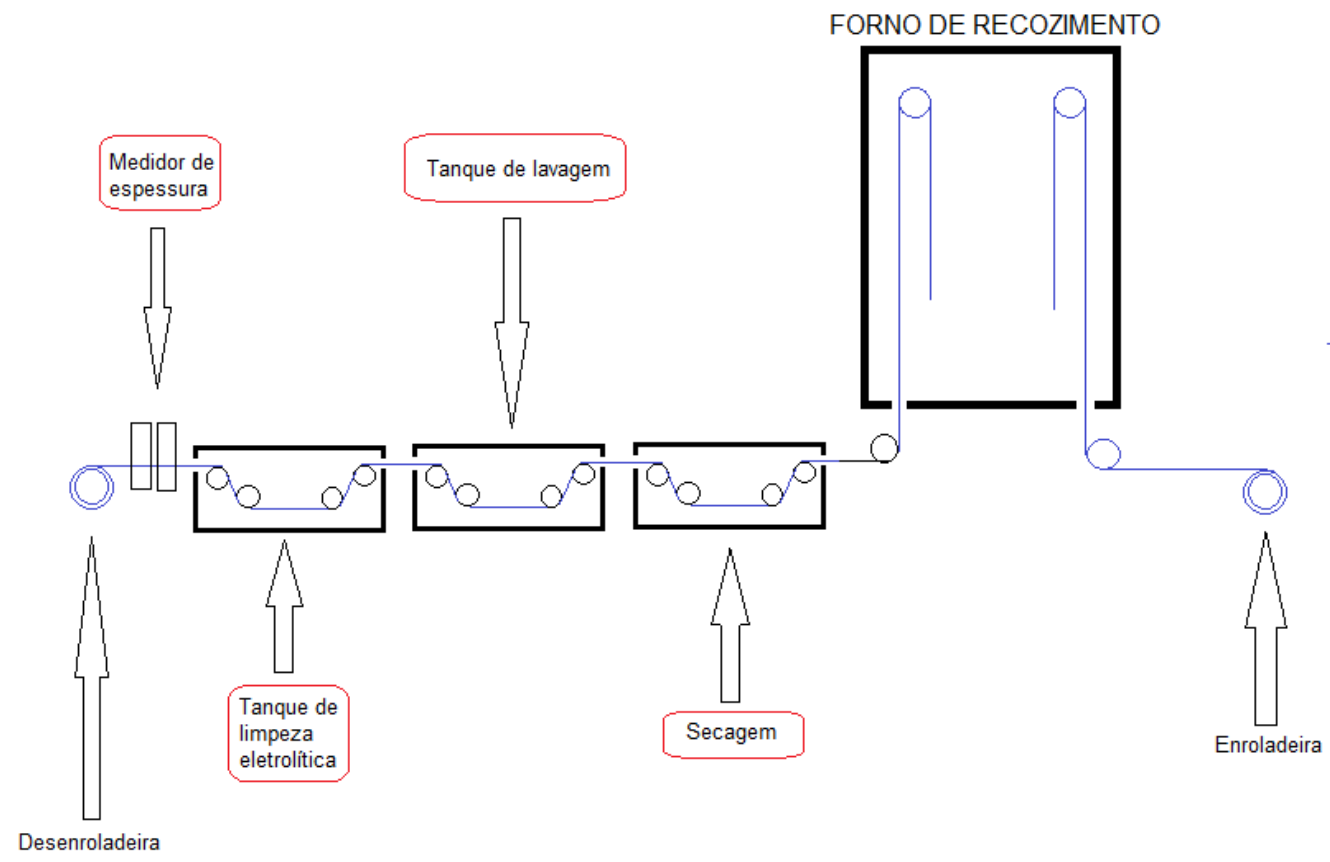

Fonte: autores

A figura 29 apresenta uma visão interna do forno de uma linha de recozimento continuo de chapas finas. Pode-se observar as seções de aquecimento, encharque e resfriamentos lentos e rápidos. 
Figura 29 - visão interna do forno de uma linha de recozimento continuo de chapas finas

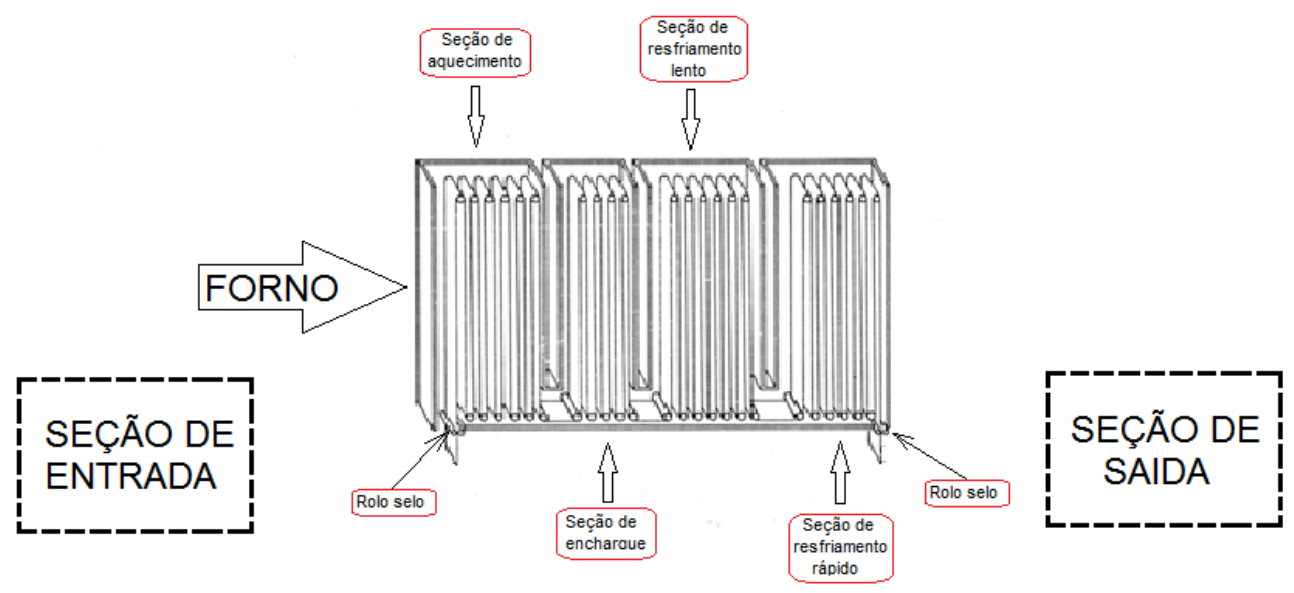

Fonte: autores

Pode-se observar, na figura, os rolos selos na entrada e na saída do forno. Estes rolos tem a finalidade de evitar que haja entrada de oxigênio no interior da câmara do forno. O forno é hermeticamente fechado e fica condicionado a uma atmosfera de nitrogênio (95\%) mais hidrogênio (5\%).

É importante salientar que, dentro do forno, tem aproximadamente 800 metros de chapa totalmente tensionado viajando a uma velocidade de até $200 \mathrm{~m} / \mathrm{min}$.

\section{REFERÊNCIAS}

[1]. Anais do XXXVII Seminário de Laminação - Processos e Produtos Laminados e Revestidos, Associação Brasileira de Metalurgia e Materiais, São Paulo, Setembro de 1999.

[2]. BOTRELL, Carlos Tratamentos Térmicos dos Aços. UFMG. 1984

[3]. CENTRO DE INFORMAÇÃO METAL MECÂNICA - CIMM. Disponível em: www.cimm.com.br. Acesso em 20 de março de 2015.
[4]. CHIAVERINI, V. Tiecnologia mecânca. v. I. 2. ed. São Paulo: Mc Graw-Hill, 1986.

[5]. GARCIA, A., SPIM, J. A.; SANTOS, C. A. Ensaios de materiais. Rio de Janeiro: Editora Livros Técnicos e Científicos S. A., 2000.

[6]. GRUNING, K. Técnicas de conformação, polígono da técnica mecânica. São Paulo: Editora Polígono, 1973.

[7]. HELMAN, H.; CETLIN, P. R. Fundamentos da conformação mecânica dos metais. Rio de Janeiro: Guanabara Dois, 1983.

[8]. Mecanismes Metallurgiques Impliques dans l'obtencions de Tôles Destinées à l'oboutissage Profond en Acier Extra-doux Calmé à L'aluminium - Sollac. France. 1975

[9]. PINTO JUNIOR, D. M. Apostila de Curso de Recozimento de Folhas Metálicas. Out/1994. Companhia Siderúrgica Nacional - CSN.

[10]. Estudo da Influência das Principais Variáveis que Influenciam no Processo 
de Recozimento. Tese de Mestrado. UFMG. Dário Moreira Pinto Junior. - 1986.

[11]. VAN VLACK, Lawrence H. Princípios de Ciência dos Materiais. Editora Edgard Blucher Ltda. - 1970.

\section{EXERCÍcIOS}

1. Cite os objetivos do recozimento dos aços.

2. Quais as principais variaveis que influenciam no processo de recozimento?

3. Quais são as diferenças básicas entre o recozimento convencional e continuo?

4. O que significa recozimento subcrítico?

5. No caso do recozimento continuo de folhas metálicas, para que serve a seção de limpeza eletrolitica na entrada das linhas?

6. Em quantas seções o forno de recozimento continuo é dividido?

7. Qual o gás utilizado nos fornos de recozimento convencional e de alta convecção?

8. Cite pelo menos duas vantagens do recozimento de fornos de alta convecção em relação aos fornos convencionais.

9. Para que servem os convectores nos fornos convencionais?

10. Para que servem os abafadores nos fornos convencionais?

\section{RESOLUÇÃO DOS EXERCÍCIOS}

1 - Remover tensões internas, diminuir a dureza, melhorar a ductilidade, ajustar o tamanho dos grãos, obter estruturas favoráveis para submeter o aço a processos posteriores e eliminar os efeitos de quaisquer tratamentos mecânicos anteriores. 
2- As principais variáveis que influenciam neste processo, no que diz respeito a qualidade superficial e de propriedades mecânicas, são: aquecimento, temperatura de encharque, tempo de encharque e de resfriamento.

3- As diferenças básicas entre o recozimento convencional e o continuo são: no convencional os tempos são maiores (dias) ao passo que no recozimento continuo é de minutos. Outra diferença básica é com relação a propriedades mecânicas e de superfície. No caso do recozimento continuo, estas propriedades são bem melhores.

4 - É aquele que é realizado em temperaturas abaixo da temperatura de início da transformação ferrítica/austenita, que é de, aproximadamente, $723^{\circ} \mathrm{C}$. Normalmente estes recozimentos são realizados em temperaturas de encharque na faixa de $650^{\circ} \mathrm{C}$ a $690^{\circ} \mathrm{C}$.

5- A seção de limpeza eletrolítica na entrada das linhas é utilizada para retirada do óleo superficial oriundo do processo de laminação a frio. Isto porque as folhas metálicas são revestidas em processo posterior.

6- O forno de recozimento continuo é dividido em: aquecimento, encharque, resfriamento lento e resfriamento rápido.

7- Nos fornos convencionais é usado um gás composto de nitrogênio (95\%) e hidrogênio (5\%) e nos fornos de alta convecção é utilizado o hidrogênio puro (100\%).
8- No recozimento de fornos de alta convecção os tempos são, praticamente, a metade em comparação aos fornos convencionais. Outra vantagem é a qualidade que é bem superior.

9- Os convectores nos fornos convencionais são utilizados para fazer a convecção do gás garantindo, assim, o processo de recozimento. Ela propicia a circulação do gas no interior das bobinas empilhadas durante o processo.

10- Os abafadores nos fornos convencionais servem para garantir proteção do material que está sendo recozido, ou seja, ele isola o produto da atmosfera. 


\section{PROCESSOS DE ESTANHAMENTO}

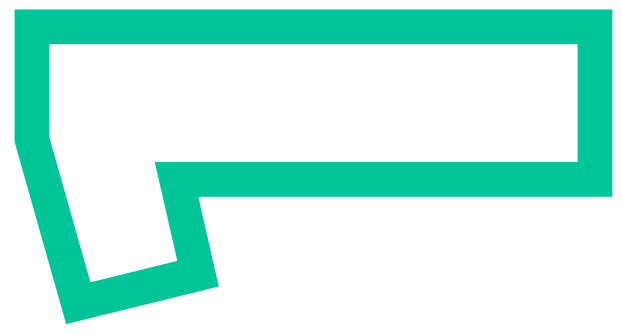

\section{Fala sobre:}

_ Introdução

_ O que é eletrólise

_ Processo de estanhamento

_ Principais variáveis no processo

_ Dicas sobre segurança

_ Referências Bibliográficas

_ Exercícios resolvidos 


\section{INTRODUÇÃO}

O estanhamento eletrolítico consiste na deposição de uma camada fina de estanho, com alta pureza, sobre o metal desejado com a finalidade principal de garantir proteção, do produto revestido, contra a oxidação.

\section{O QUE É ELETROLISE}

A eletrólise é um método usado para a obtenção de reações de oxidorredução. Em soluções eletrolíticas, o processo se baseia na passagem de uma corrente elétrica através de um sistema líquido que tenha íons presentes, gerando, assim, reações químicas dentro do banho eletrolítico.

Inicialmente, será feita neste capítulo uma explanação resumida sobre o processo de eletrólise. Isto porque uma linha de estanhamento eletrolítico, como o próprio nome já diz, é totalmente baseada no processo de eletrólise.

As reações na eletrólise podem ocorrer de várias maneiras, dependendo do estado físico em que estiver a solução que vai ser submetida à reação.

A figura 30 apresenta uma cuba eletrolítica, mostrando os eletrodos positivo e negativo e uma fonte de alimentação que pode ser um gerador de corrente contínua.

Figura 30 - representação esquemática de uma cuba eletrolítica mostrando os eletrodos positivo e negativo e uma fonte de alimentação

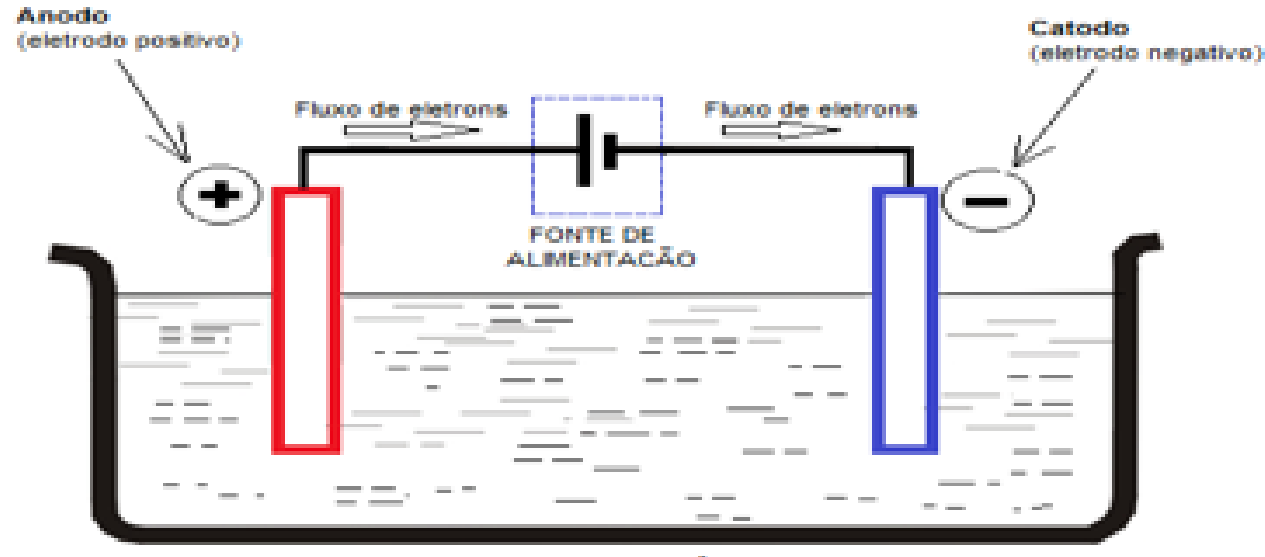

Fonte: autores CUBA ELETROLITICA

A eletrólise ocorre em cubas, ou células eletrolíticas, com dois eletrodos ligados aos terminais de um gerador de corrente contínua. O eletrodo negativo, chamado de anodo, atrai cátions e é nele que ocorre a redução do cátion, ao passo que o eletrodo positivo, chamado de cátodo, atrai ânions e, por isso, é aqui que se dá a oxidação do ânion.
Nesse processo, os elétrons emergem da fonte de alimentação pelo ânodo (-) e entram na celula eletrolítica pelo cátodo (+), no qual produz a redução. 
PROCESSO DE ESTANHAMENTO ELETROLÍTICO

O estanhamento eletrolítico consiste na deposição de uma camada fina de estanho, da ordem de microns, sobre o metal desejado, que, normalmente é um aço de baixo teor de carbono. No caso de uma empresa siderúrgica, normalmente, este processo é aplicado às folhas metálicas (folhas de flandres). Este produto é destinado à fabricação de embalagens metálicas, tais como: comestíveis, tintas, vernizes, óleos, dentre outros.

O estanho é um metal de cor branco-prateada, macio, com uma boa resistência anti-corrosiva contra as influências da atmosfera, umidade, soluções aquosas de sal e ácidos fracos; Não é venenoso, o que o torna muito utilizado em grande escala na indústria alimentícia.

A folha metálica é imersa em vários tanques verticais com solução (eletrólito), contendo íons de estanho (Sn), provenientes dos anodos do próprio estanho. Com a passagem da corrente elétrica, que pode ser fornecida por geradores de corrente contínua ou por circuito eletronico (diodos), estes íons são depositados nas superficies da tira que atua como cátodo, ao longo de vários passes, obtendo, assim, a camada de revestimento desejado.

A figura 31 apresenta um exemplo de um tanque de eletrodeposição de uma linha de estanhamento eletrolítico de uma empresa produtora de folhas de fladres. $\mathrm{Na}$ figura, pode-se visualizar um exemplo de um tanque de uma linha de estanhamento eletrolítico, em que vemos os rolos condutores, a solução eletrolítica e os anodos de estanho de alta pureza. Sendo que os rolos condutores, como o próprio nome já diz, servem para fazer a conduçao da energia elétrica para garantir a eletrólise.

Figura 31 - tanque de eletrodeposição de uma linha de estanhamento eletrolítico mostrando as principais partes (tanque, rolos condutores, ponte de anodos e anodos de estanho)

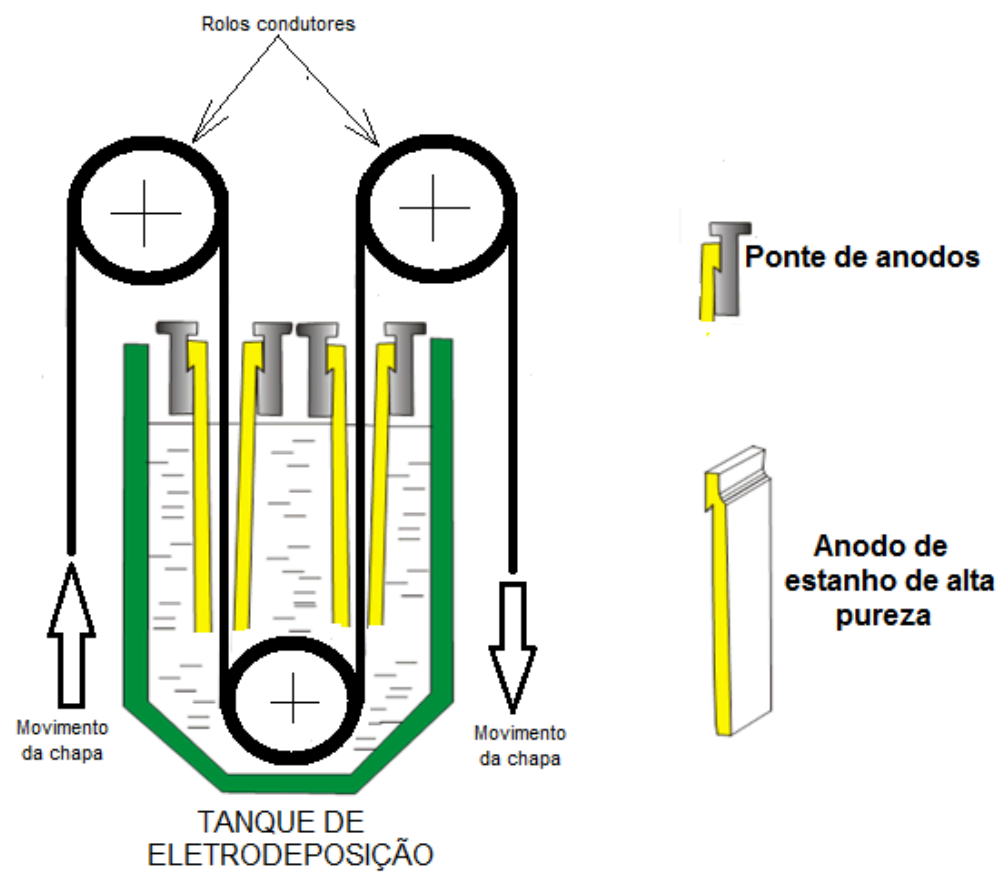


Os revestimentos usuais, conforme catálogo ABNT(2010), em g/m2, inseridos nas folhas metálicas estanhadas nas linhas de produção, são: 1,1; 2,8; 5,6; 8,4 e 11,2 g/ $\mathrm{m} 2$. Sendo o revestimento $1,1 \mathrm{~g} / \mathrm{m} 2$ o mais leve e o revestimento $11,2 \mathrm{~g} / \mathrm{m} 2$ o mais pesado, que é utilizado no caso aplicações cuja solicitação é de uma maior proteção para acondicionado nas embalagens.

As principais variáveis no processo são: densidade de corrente elétrica aplicada nos anodos, temperatura da solução eletrolítica, acidez do eletrólito e a velocidade da linha de estanhamento. Elas influem diretamente no resultado da camada de revestimento aplicada nas folhas metálicas.

Vale salientar que existe, também, um processo bastante parecido com o estanhamento, que é o processo de cromagem eletrolítica. Neste caso, a camada depositada nas superficies da folha é o cromo metálico.

No que diz respeito aos ensaios realizados no produto revestido, destacam-se os ensaios de espessura da camada de revestimento de estanho e ensaios de dureza superficial. Dependendo do produto e do cliente, faz-se, também, ensaios de tração uniaxial e, finalmente, os ensaios metalográficos (metalografia), através de microscopia ótica.

As principais aplicações deste produto são: óleos vegetais, peixe, frutas, carne, leite, bebidas em geral, tintas, solventes, ceras e pilhas.

\section{OS DIFERENTES TIPOS DE FOLHAS METÁLICAS}

Folha estanhada - é um produto plano de aço de baixo carbono com espessura variando de 0,15 a 0,45 mm e revestimento de estanho em ambas as faces pelo processo de eletrodeposição.

Folha cromada - é um produto plano de aço de baixo carbono com espessura máxima de 0,15 a 0,45 mm, com uma finíssima camada de revestimento de cromo metálico em ambas as faces pelo processo de eletrodeposição.

Folha de simples redução - espessura final obtida por um único processo de laminação a frio, ou seja, após o laminador de tiras a frio. A redução é de aproximadamente $90 \%$.

Folha de dupla redução - espessura final obtida através de dois processos de laminação a frio laminador de tiras a frio, recozimento intermediário e laminador de dupla-redução. A redução varia de 20 a $30 \%$.

A figura 32 apresenta uma folha estanhada (a) e uma folha cromada (b) em corte. São mostradas as camadas formadas durante os processos de estanhamento e cromagem. Ambos são processos contínuos. 
Figura 32 -perfil de uma folha estanhada e de uma folha cromada, em corte, mostrando as camadas formadas em uma de suas superfícies

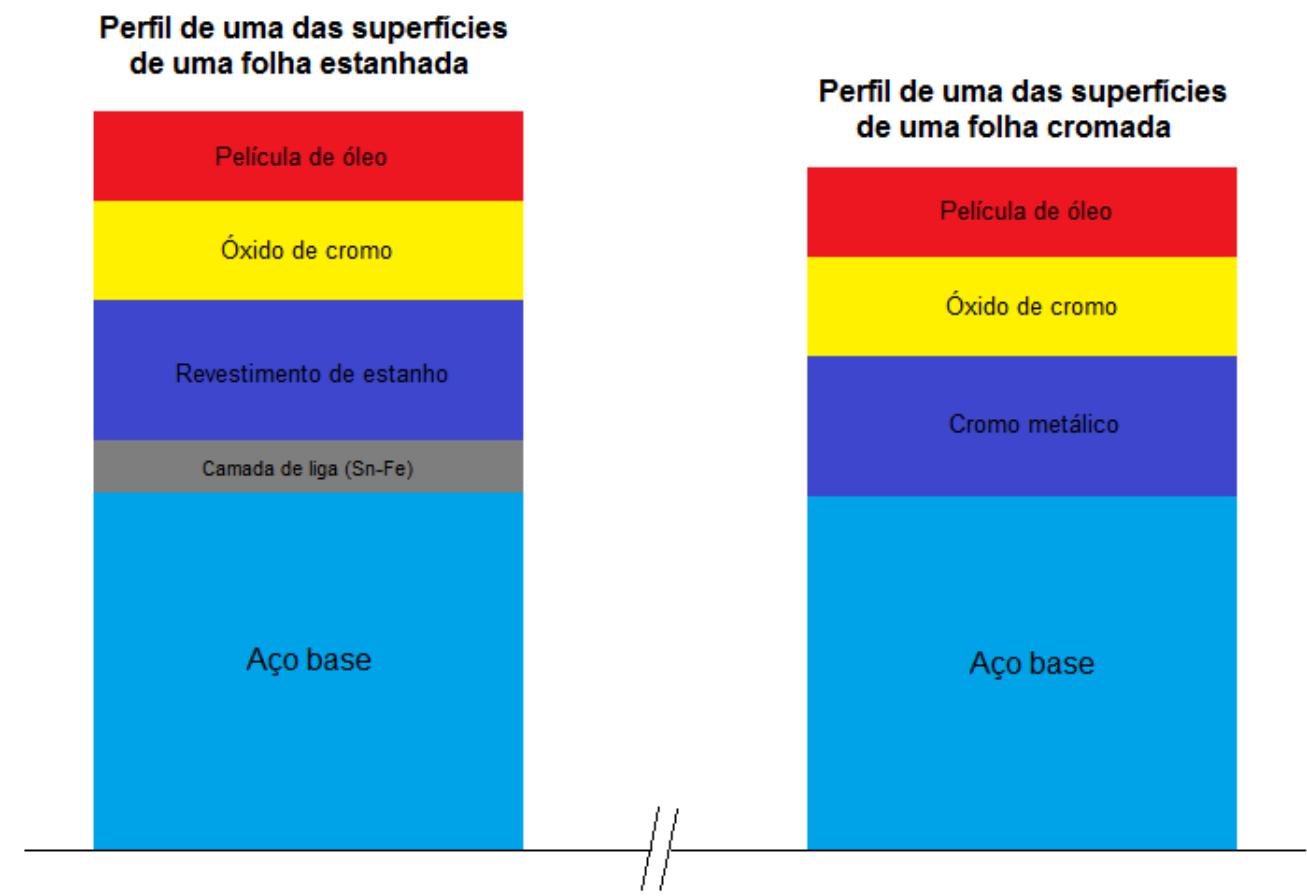

Fonte: autores

PRINCIPAIS

APLICAÇÕES DAS FOLHAS METÁLICAS ESTANHADAS E CROMADAS

As folhas metálicas são fabricadas com o objetivo de atender às necessidades específicas de resistência, conformação, revestimento, acabamento e dimensão adequadas à fabricação das embalagens a que se destinam. Se subdividem em: estanhadas e cromadas.

As folhas estanhadas são largamente utilizadas para embalagens de produtos alimentícios, como por exemplo - atomatados (polpa, purê, molhos e extratos), leites (em pó, condensados e cremes), óleos, bebidas (refrigerante, sucos, energéticos e cerveja) e conservas (milho, ervilha e aspargos), doces e frutas em calda, manteiga e pescados (atum e sardinha). Também é utilizada em embalagens de tintas, thinner, cola e vernizes, pet food e revestimento de pilhas.

As folhas cromadas são utilizadas para embalagens de produtos alimentícios, como pescados, rolhas metálicas e também para embalagens promocionais. Além disso, este produto é largamente utilizado na confecção de tampas e fundos das embalagens de 3 peças e magazine de filme fotográfico.

\section{ASPECTOS DE QUALIDADE}

Uma das principais características da folha metálica é com relação a propriedades mecânicas. A figura 33 apresenta o fluxo de produçao do produto folha estanhada. 
Figura 33 - Fluxo de produçao do produto folha estanhada

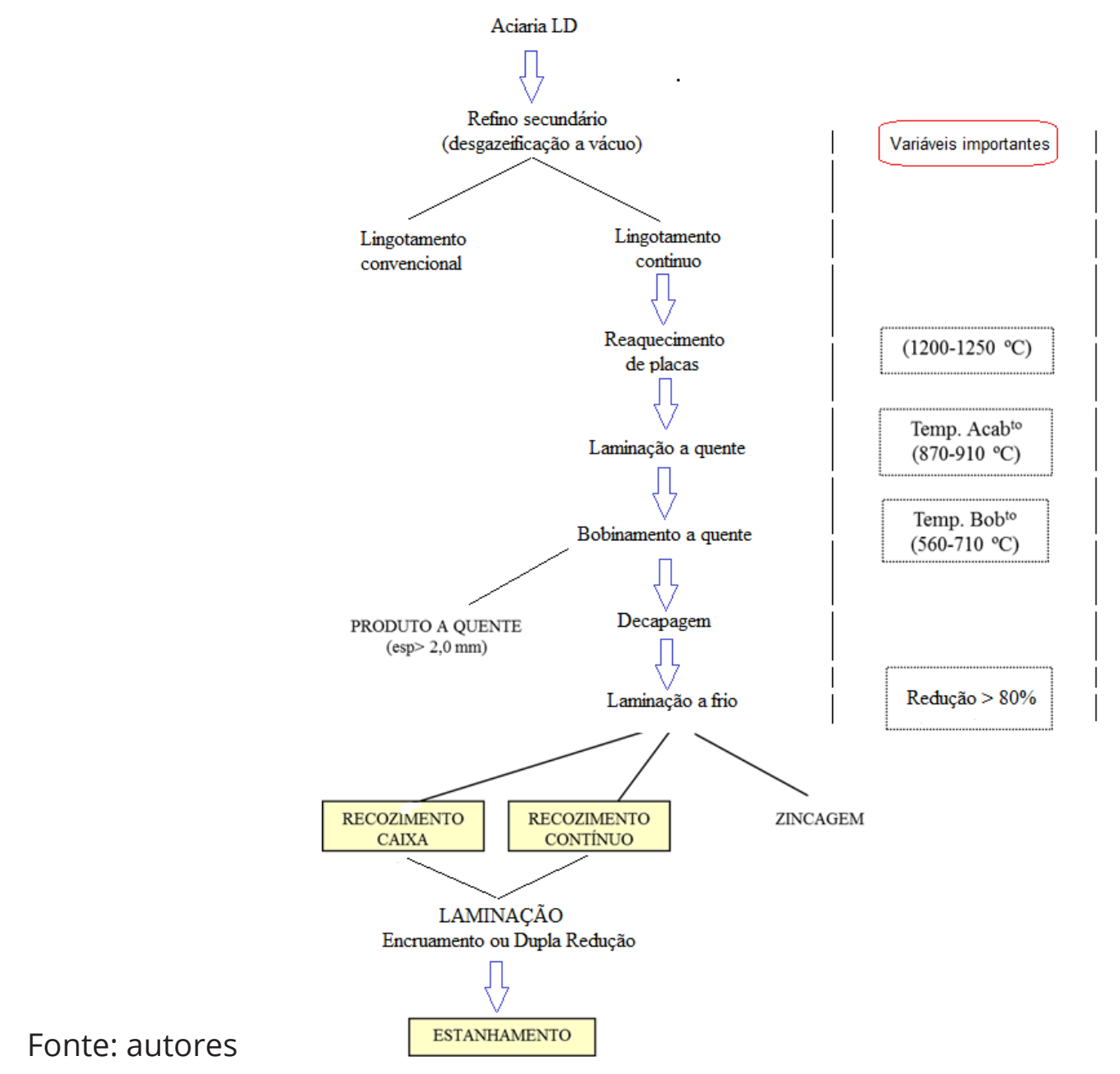

É interessante destacar que os processos

DIMENSÕES PADRÃO de aciaria, laminaçao a quente e recoDAS FOLHAS zimento tem uma grande influencia no controle, nas propriedades mecânicas.

Outra característica muito importante a se controlar é a camada de revestimento, depositada em ambas as superficies. $\mathrm{Na}$ realidade, tem-se sobre o aço base as seguintes camadas: camada de estanho, camada de liga (estanho-ferro), uma camada de óxido de cromo (passivação) e, METÁLICAS

As dimensões padrão estão conforme a norma NBR 6665. A tabela II apresenta alguns valores de espessuras utilizados na prática. Pode-se observar também, na tabela, os valores correspondentes das massas (kg/m2 e $\mathrm{lb} / \mathrm{cb})$, relativos às referidas espessuras.

finalmente, uma película de óleo. É importante frizar que estas camadas são depositadas em ambas as superficies, ou seja, superior e inferior. 
Tabela 2 - Exemplos de espessuras de folhas metálicas utilizadas na prática bem como os valores de massa correspondentes

\begin{tabular}{ccc} 
ESPESSURA $(\mathbf{m m})$ & \multicolumn{2}{c}{ Massa } \\
& $\mathbf{k g} / \mathbf{m} \mathbf{2}$ & $\mathbf{l b} / \mathbf{c ~ b}$ \\
\hline 0,16 & 1,26 & 57 \\
\hline 0,20 & 1,57 & 70 \\
\hline 0,22 & 1,73 & 80 \\
\hline 0,25 & 1,96 & 90 \\
\hline 0,27 & 2,12 & 95 \\
\hline
\end{tabular}

$\mathrm{lb} / \mathrm{cb}=$ libras por caixa base

\section{PROPRIEDADES MECÂNICAS DAS FOLHAS METÁLICAS}

As propriedades mecânicas das folhas metálicas dependem de vários fatores, tais como: composição química do aço base, variáveis de laminação a quente (temperatura de acabamento e de bobinamento), taxa de redução a frio e processo de recozimento após a laminação a frio.

Para avaliar sua resistência mecânica, é feito o Ensaio de Dureza Superficial Dureza Rockwell, na escala HR30T. É um ensaio de rotina, ou seja, é feito em toda bobina processada. É importante salientar que, em alguns casos, é feito também o ensaio de Tração Uniaxial e/ou análise metalográfica. Como por exemplo, pode ser citado o caso das folhas metálicas de Dupla Redução (FM-DR). A tabela III apresenta os valores de dureza superficial Rockwell para as folhas metálicas de simples e dupla-redução.

Tabela 3 - Dureza Superficial Rockwell para as folhas metálicas de simples e dupla-redução

\begin{tabular}{|c|c|c|c|c|}
\hline \multirow{2}{*}{ Redução } & \multirow{2}{*}{ Tipo } & \multicolumn{3}{|c|}{ Dureza Rockwell (HR30T) } \\
\hline & & $\mathrm{e} \leq 0,21 \mathrm{~mm}$ & $0,21 \leq e \leq 0,28 \mathrm{~mm}$ & $e>0,28 \mathrm{~mm}$ \\
\hline \multirow{3}{*}{ SIMPLES } & $\mathrm{T} 1$ & 53 max. & $52 \max$ & 51 max. \\
\hline & $\mathrm{T} 2$ & $53 \pm 4$ & $52 \pm 4$ & $51 \pm 4$ \\
\hline & T3 & $58 \pm 4$ & $57 \pm 4$ & $56 \pm 4$ \\
\hline \multirow{2}{*}{ REDUÇÃO } & $\mathrm{T} 4$ & $62 \pm 4$ & $61 \pm 4$ & $60 \pm 4$ \\
\hline & $\mathrm{T} 5$ & $65 \pm 4$ & $65 \pm 4$ & $64 \pm 4$ \\
\hline \multirow{4}{*}{$\begin{array}{c}\text { DUPLA } \\
\text { REDUÇÃO }\end{array}$} & DR520 & $70 \pm 3$ & $70 \pm 3$ & - \\
\hline & DR550 & $73 \pm 3$ & $73 \pm 3$ & - \\
\hline & DR620 & $76 \pm 3$ & $76 \pm 3$ & - \\
\hline & DR660 & $77 \pm 3$ & $77 \pm 3$ & - \\
\hline
\end{tabular}

$\mathrm{T}$ = grau de dureza (Temper) / DR = dupla redução $/$ e = espessura 
No caso das folhas metálicas de dupla-redução, as propriedades mecânicas são avaliadas, também, através do ensaio de tração uniaxial. Leva-se em consideração, principalmente, os valores de limite de escoamento (LE). A tabela IV apresenta os valores dos limites de escoamento das folhas metálicas de dupla-redução, bem como suas faixas de variações.

Tabela 4 - Valores dos limites de escoamento das folhas metálicas de dupla-redução

\begin{tabular}{cc} 
Tipo & LE (Mpa) \\
DR 520 & $520 \pm 70$ \\
\hline DR 550 & $550 \pm 70$ \\
\hline DR 620 & $620 \pm 70$ \\
\hline DR 660 & $660 \pm 70$ \\
\hline
\end{tabular}

\section{TIPOS DE}

\section{REVESTIMENTOS DAS FOLHAS METÁLICAS}

\section{Revestimento com estanho}

(folha estanhada)

Os revestimentos podem ser de diferentes tipos, os quais são caracterizados pela massa de estanho depositadas em ambas as faces. A tabela $V$ apresenta os tipos e os valores dos revestimentos usuais das folhas metálicas estanhadas. Vale salientar que esta tabela se refere a revestimentos iguais em ambas as faces. São referenciados pela letra "E".

Tabela 5 - Tipos e valores dos revestimentos (iguais) usuais das folhas metálicas

\begin{tabular}{|c|c|c|c|}
\hline \multirow{2}{*}{ Tipo } & \multicolumn{2}{|c|}{ Nominal (g/m2) } & \multirow{2}{*}{$\begin{array}{c}\text { Mínimo ensaio triplo }(\mathrm{g} / \mathrm{m} 2) \\
\text { Duas faces }\end{array}$} \\
\hline & Uma face & Duas faces & \\
\hline E 1,1/1,1 & 1,1 & 2.2 & 1.6 \\
\hline E $2,8 / 2,8$ & 2,8 & 5.6 & 4.9 \\
\hline E 5,6/5,6 & 5,6 & 11.2 & 10.5 \\
\hline E $8,4 / 8,4$ & 8,4 & 16.8 & 15.7 \\
\hline E $11,2 / 11,2$ & 11,2 & 22.4 & 20.2 \\
\hline
\end{tabular}

* = média de 3 pontos (NBR 6665)

A tabela VI apresenta os tipos e os valores dos revestimentos diferenciais usuais das folhas metálicas estanhadas. A letra " $D$ ", significa que o revestimento é diferencial. 
Tabela 6 - Tipos e valores dos revestimentos diferenciais das folhas metálicas estanhadas

\begin{tabular}{|c|c|c|c|c|}
\hline \multirow{2}{*}{ Tipo } & \multicolumn{2}{|c|}{ Nominal (g/m2) } & \multicolumn{2}{|c|}{ Mínimo ensaio triplo (g/m2)* } \\
\hline & Face A & Face B & Face A & Face B \\
\hline D $2,8 / 1,1$ & 2,8 & 1,1 & 2,25 & 0,80 \\
\hline D 5,6 /2,8 & 5,6 & 2,8 & 4,75 & 2,25 \\
\hline D $8,4 / 2,8$ & 8,4 & 2,8 & 7,85 & 2,25 \\
\hline D 8,4/5,6 & 8,4 & 5,6 & 7,85 & 4,75 \\
\hline D $11,2 / 2,8$ & 11,2 & 11,2 & 2,8 & 5,6 \\
\hline D $11,2 / 5,6$ & 10,1 & 10,1 & 2,75 & 4,75 \\
\hline
\end{tabular}

* = média de 3 pontos (NBR 6665)

As folhas metálicas estanhadas com revestimento diferencial recebem uma identificação em forma de linhas contínuas, na direção de laminação, na superfície de maior revestimento. No caso do revestimento $\mathrm{D} 5,6 / 2,8$, são separadas a uma distância de $12,7 \mathrm{~mm}$. Já o revestimento D8,4/2,8, a distância é de 25,4 mm. O revestimento $D 8,4 / 5,6$ são distâncias alternadas de 38,0 e 25,4 mm. E, finalmente, o revestimento D11,2/5,6 é representado por linhas alternadas que distam de 38,0 e 12,7 mm.

\section{REVESTIMENTO COM CROMO (FOLHA CROMADA)}

É um produto constituído por uma finíssima camada de revestimento de cromo metálico em ambas as faces. A tabela VII apresenta os valores máximos e mínimos de cromo metálico e óxido de cromo das folhas cromadas. Vale destacar que são resultados de ensaio triplo, ou seja, é a média das determinações feitas em 3 corpos de prova de uma mesma folha, de acordo com a Norma NBR 6665.

Tabela 7 - Valores máximos e mínimos de cromo metálico e óxido de cromo das folhas cromadas

\begin{tabular}{|c|c|c|c|c|}
\hline Tipo & \multicolumn{2}{|c|}{ Cromo metálico (g/m2) } & \multicolumn{2}{|c|}{ Óxido de cromo (g/m2) } \\
\hline \multirow{2}{*}{60} & Máximo & Mínimo & Máximo & Mínimo \\
\hline & 30 & 140 & 5 & 27 \\
\hline
\end{tabular}

\section{FILME DE PASSIVAÇÃO DAS FOLHAS METÁLICAS}

Também conhecido como tratamento eletroquímico de superfície, visa obter uma película de óxido de cromo, com a finalidade de uma proteção maior contra a oxidação. São dois diferentes tratamentos eletroquímicos (311 e o 314). São atendidos nas seguintes faixas:

Tratamento 311 - faixa de 3,5 e 6,5 mg/m2

Tratamento 314 - acima de 6,5 mg/m2 


\section{DICAS PARA OS ENGENHEIROS, TECNÓLOGOS, TÉCNICOS E PESSOAL DE OPERAÇÃO}

- Utilizar sempre os procedimentos de segurança da área de trabalho.

- Andar somente em locais determinados.

_ Observar as placas de sinalização.

_ Utilizar os EPIs recomendados pela área local.

\section{REFERÊNCIAS}

[1]. ABNT - ASSOCIAÇÃO BRASILEIRA DE NORMAS TÉCNICAS. Norma ABNT NBR 6665:2010. Disponível em www.abntcatalogo.com.br. Acesso em 5 de abril de 2015.

[2]. CIMM - CENTRO DE INFORMAÇÃO METAL MECÂNICA. Disponível em: www.cimm.com.br. Acesso em 20 de março de 2015.

[3]. CSN - COMPANHIA SIDERURGICA NACIONAL. Catálogo de Produtos. Disponível em: http://www.csn.com.br. Acesso em 5 de abril de 2015.

[4]. GARCIA, A., SPIM, J. A.; SANTOS, C. A. Ensaios de materiais. Rio de Janeiro: Editora Livros Técnicos e Científicos S. A., 2000.

[5]. KSC - KAWASAKI STEEL CORPORATION. Disponível em: www.kawasakitrading.co.jp/eg/products/steel. Acesso em 5 de abril de 2015.
[6]. PINTO JUNIOR, D. M. Apostila de Curso de Estanhamento de Folhas Metálicas. Out/1990. Companhia Siderúrgica Nacional - CSN.

[7]. USS - UNITED STATE STEEL CORPORATION. Catálogo de Produtos. Disponível em: https://www.ussteel.com/uss/portal. Acesso em 5 de abril de 2015. 


\section{EXERCÍcIOS}

1. Em que consiste o estanhamento eletrolítico?

2. Qual a importância de se conhecer a eletrólise num processo de estanhamento?

3. Explique, resumidamente, o processo de eletrólise.

4. Que nome se dá ao eletrodo positivo e ao eletrodo negativo?

5. O que é folha de flandres?

6. Quais são os pesos de revestimentos de estanho usuais?

7. Quais são as principais variáveis num processo de estanhamento?

8. Dê exemplos de aplicações de folhas estanhadas.

9. Dê exemplos de aplicações de folhas cromadas.

10. Quais são as camadas depositadas nas folhas estanhadas?

\section{RESOLUÇÃO DOS EXERCÍCIOS}

1. O estanhamento eletrolítico consiste na deposição de uma camada fina de estanho, com alta pureza, sobre o metal desejado com a finalidade principal de garantir proteção, do produto revestido, contra a oxidação.

2. A eletrólise é um método usado para a obtenção de reações de oxidorredução.
A eletrolise é a base de um processo de estanhamento porisso é interessante conhecer este processo.

3. A eletrólise é um método usado para a obtenção de reações de oxidorredução. Em soluções eletrolíticas, o processo se baseia na passagem de uma corrente elétrica através de um sistema líquido que tenha íons presentes, gerando, assim, reações químicas dentro do banho eletrolítico.

4. O eletrodo negativo é chamado de anodo, que atrai cátions, e é nele que ocorre a redução do cátion, ao passo que o eletrodo positivo, chamado de cátodo, que atrai ânions e, por isso, é nele que se dá a oxidação do ânion.

5. É um produto plano de aço de baixo carbono com espessura variando de 0,15 a $0,45 \mathrm{~mm}$ e revestimento de estanho em ambas as faces pelo processo de eletrodeposição.

6. Os revestimentos usuais, conforme catálogo ABNT(2010), em g/m2, inseridos nas folhas metálicas estanhadas nas linhas de produção, são: 1,1; 2,8; 5,$6 ; 8,4$ e $11,2 \mathrm{~g} / \mathrm{m} 2$.

7. As principais variáveis no processo são: densidade de corrente elétrica aplicada nos anodos, temperatura da solução eletrolítica, acidez do eletrólito e a velocidade da linha de estanhamento. Elas influem diretamente no resultado da camada de revestimento aplicada nas folhas metálicas. 
8. As folhas estanhadas são largamente utilizadas para embalagens de produtos alimentícios, como por exemplo atomatados (polpa, purê, molhos e extratos), leites (em pó, condensados e cremes), óleos, bebidas (refrigerante, sucos, energéticos e cerveja) e conservas (milho, ervilha e aspargos), doces e frutas em calda, manteiga e pescados (atum e sardinha). Também é utilizada em embalagens de tintas, thinner, cola e vernizes, pet food e revestimento de pilhas.

9. As folhas cromadas são utilizadas para embalagens de produtos alimentícios, como pescados, rolhas metálicas e também para embalagens promocionais.

10. Na realidade, tem-se, sobre o aço base as seguintes camadas: camada de estanho, camada de liga (estanho-ferro), uma camada de óxido de cromo (passivação) e, finalmente, uma película de óleo. É importante frizar que estas camadas são depositadas em ambas as superficies, ou seja, superior e inferior. 


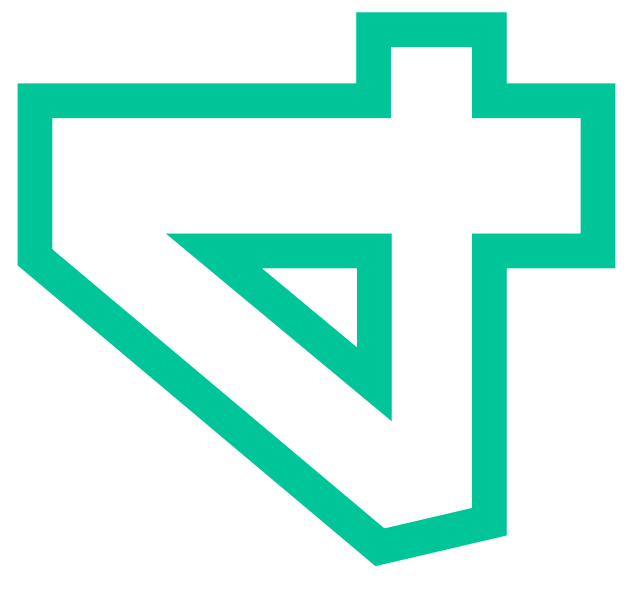

\section{PROCESSO DE ZINCAGEM}

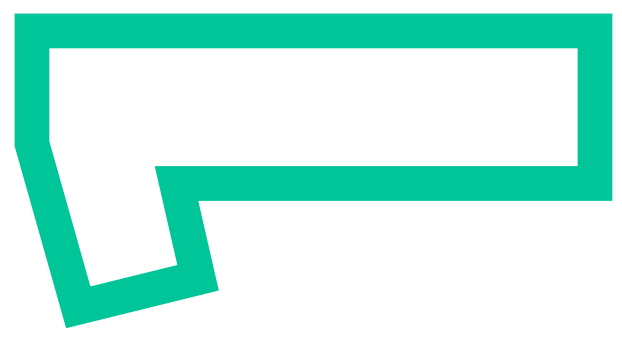

\section{Fala sobre:}

_ Introdução

_ O que é corrosão

_ Processo de zincagem por imersão

_ Variáveis que influenciam

_ Principais aplicações

_ Referências Bibliográficas

_ Aspectos de qualidade

_ Exercícios resolvidos 
O processo de zincagem, também conhecido como galvanização, consiste na deposição de uma camada de zinco por eletrodeposição ou pelo simples banho químico. O processo propicia uma proteção contra a oxidação.

\section{INTRODUÇÃO}

Atualmente, o processo de revestimento contínuo de tiras laminadas a frio e recozidas é bastante utilizado e empregado em todo o mundo. Para se ter uma ideia, o processo por imersão foi originalmente desenvolvido no século passado. Naquela época, era voltado para a galvanização (revestimentos de zinco). É um processo utilizado, também, para outros metais bases. Os profissionais antigos, provavelmente, não reconheceriam as linhas de revestimentos atuais.

O processo de zincagem, com o passar do tempo, se transformou numa operação avançada tecnicamente e muito sofisticada. Isto se tornou possível graças à disponibilidade de sistemas de controle computadorizados eletro-mecânicos.

Originalmente, o produto oriundo de imersão a quente, era utilizado para aplicações que não demandavam uma alta qualidade de acabamento e também um alto grau de conformabilidade. Nos dias de hoje, as indústrias consumidoras estão utilizando produtos revestidos por imersão a quente para aplicações bastantes exigentes em termos de qualidade, solda- bilidade e conformabilidade. Podemos citar itens utilizados na indústria automobilística, tais como: capôs, pára-choques e portas. Essas aplicações não só precisam de uma excelente qualidade de superfície, mas também exigem um alto grau soldabilidade, aliado a uma boa conformabilidade.

As chapas revestidas por imersão a quente são produzidas com espessuras entre 0,30 e 1,20 milímetros, considerando o processo contínuo. As espessuras processadas podem chegar até 4,00 milímetros (processo não contínuo - chapa a chapa).

A maneira mais comum de fazer pedidos de chapas de aço revestidas aos fornecedores de aço é se referindo às Normas ASTM. Estas normas, escritas por comitês de redação de normas voluntários dentro da organização internacional ASTM, abrangem todos os detalhes relacionados a pedidos de chapas de aço revestidas. Estes detalhes incluem: tipo de revestimento, peso da camada de revestimento, acabamento superficial, resistência do substrato, dimensões do aço base, tais como espessura e largura e tolerâncias (dimensões e espessura do revestimento).

A proteção propiciada pelo zinco é conhecida como proteção de sacrifício. Isto porque a camada superficial de zinco depositada se sacrifica para proteger o substrato que é o aço. Em outras palavras, os metais mais redutores se corroem em lugar dos menos redutores. 


\section{CORROSÃO}

$\mathrm{Na}$ literatura encontra-se várias definições sobre a corrosão. Alguns autores defendem que é uma oxidação. Outros relatam que é um ataque químico ou um fenômeno elétrico denominado de eletrólise. Todas estas proposições estão corretas. Uma corrosão pode ainda ocorrer em diferentes meios.

A corrosão é o fenômeno de deterioração com perda de material devido a modificações químicas e eletrônicas que ocorrem por reações com o meio ambiente. Ela propicia a falha direta dos metais quando estão em algum tipo de serviço e os torna suscetíveis de romper por algum outro mecanismo.

A corrosão pode ocorrer com muita intensidade em estruturas metálicas submersas, tais como minerodutos, oleodutos, gasodutos, cabos de comunicação e de energia elétrica.

A corrosão ocorre, também, com bastante intensidade nos meios de transportes, tais como: trens, navios, automóveis, caminhões, embarcações em geral.

É oportuno citar que ela pode ocorrer, também, nos meios de comunicação, como de transmissão de estações de rádio, de TV, repetidoras, de radar, antenas etc. Todas essas estruturas representam investimentos vultosos que exigem uma durabilidade e resistência à corrosão para que justifiquem os valores investidos e evitem acidentes com danos materiais incalculáveis ou danos pessoais irreparáveis.

O ferro e suas ligas são os materiais de construção mecânica de maior importância e também os mais sujeitos e mais sensíveis a ação do meio corrosivo. É natural que os fenômenos relacionados com a corrosão do ferro sejam os mais estudados e os mais conhecidos.

A figura 34 apresenta uma ilustração de três diferentes técnicas de combate a corrosão.

Figura 34 - representação de três diferentes técnicas de combater a corrosão

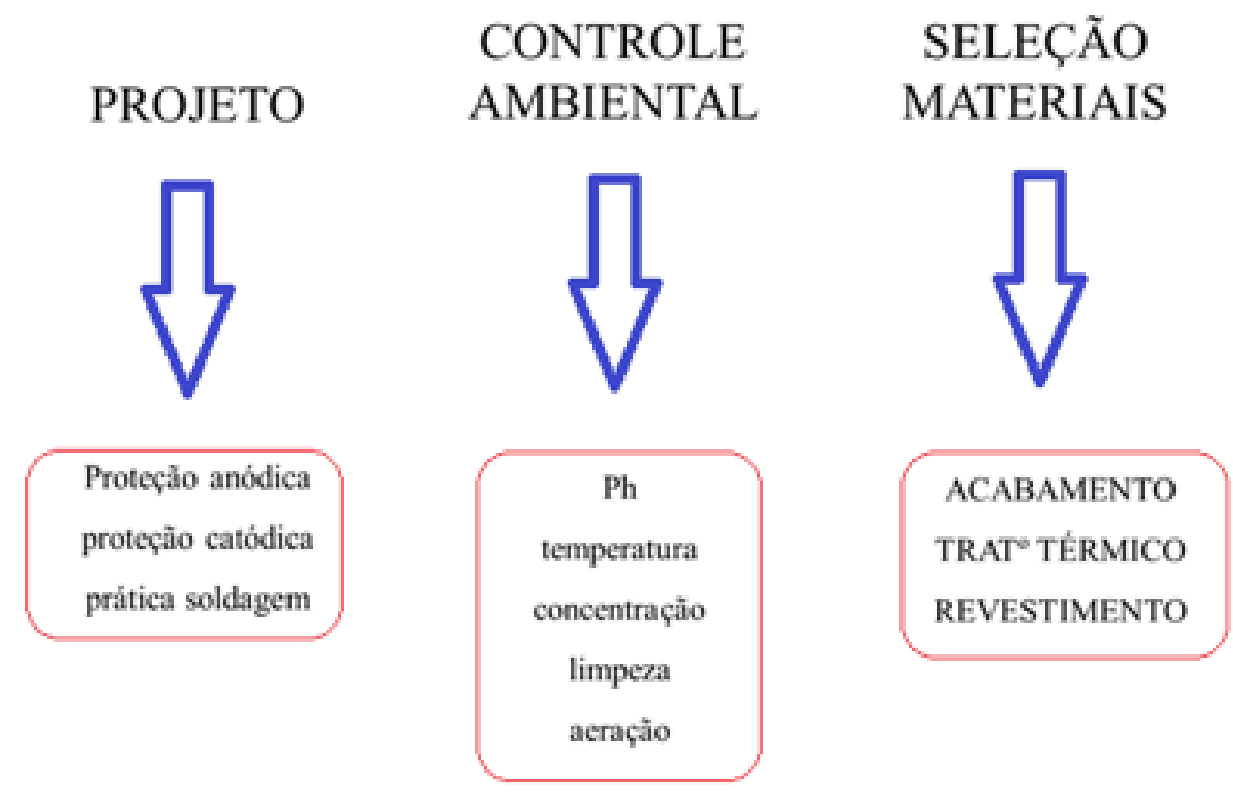

Fonte: autores 
PROCESSO DE

ZINCAGEM POR

IMERSÃO

Um revestimento galvanizado é essencialmente um revestimento de zinco sobre uma chapa de aço laminada a frio e recozida. A palavra "galvanizar" vem da proteção galvânica que o zinco fornece ao aço quando exposto a um ambiente corrosivo. Este é, de longe, o produto por imersão a quente mais comum com uma ampla gama de aplicações.

É importante frisar que existe uma camada de liga Fe-Zn entre o aço base e a camada superficial de zinco. Esta camada de liga é formada por um tratamento térmico feito logo após a saída da chapa do pote de zinco. Lembrando que, com a formação desta camada de liga, dá origem a outro produto. Este produto é dotado de melhor qualidade superficial, melhor soldabilidade, considerando o processo por solda a pontos e melhor conformabilidade, quando comparado com aquele sem a camada de liga.

O zinco fornece tanto a proteção galvânica quanto a proteção denominada de barreira. A proteção galvânica é maior que qualquer outro tipo de revestimento por imersão a quente em aço.

Vale destacar que o revestimento contém alumínio - normalmente entre 0,20 e 0,30\%. O alumínio é adicionado ao banho de zinco fundido para controlar a taxa de crescimento de uma camada da liga (zona de ligação entre o aço e o revestimento e zinco). Ele aumenta drasticamente a adesão do revestimento, o que permite a moldagem rigorosa da chapa revestida.

O revestimento pode conter uma pequena quantidade de chumbo e/ou antimônio para o desenvolvimento de brilho. Quase todos os produtos galvanizados não contêm chumbo e, quando contém, o chumbo é menor que 0,03\%.

Além do revestimento com 100\% de zinco, existem diferentes tipos de revestimentos com zinco na composição: Galvanneal (90 \% Zinco-10\% Ferro), Alumínio-Zinco (55\% Alumínio- e 65\% Zinco), dentre outros. É importante destacar que o Galvanneal é muito utilizado na indústria automobilística em decorrência, principalmente, da característica de muito boa soldabilidade.

A maneira mais comum de fazer pedidos de chapas de aço revestidas aos fornecedores de aço é se referindo às Normas ASTM. Estas normas, escritas por comitês de redação de normas voluntários dentro da organização internacional ASTM, abrangem todos os detalhes relacionados a pedidos de chapas de aço revestidas. Estes detalhes incluem: tipo de revestimento, peso da camada de revestimento, acabamento superficial, resistência do substrato, dimensões do aço base, tais como espessura e largura e tolerâncias (dimensões e espessura do revestimento).

Como o próprio nome já diz, o revestimento contínuo por imersão a quente é relativo a aplicação de um revestimento de zinco puro fundido na superfície de uma tira de aço. Este é um processo contínuo. Basicamente 
falando, a tira de aço atravessa, continuamente, um banho de zinco fundido. A velocidade chega a ser na ordem de 180 metros por minuto (mpm). A secagem e controle da espessura da camada de revestimento é feita através de uma cortina (navalha) de ar sob pressão adaptado logo após a saída do banho fundido.

Após a tira passar pela seção de recozimento, a temperatura é controlada de tal forma a se manter num valor ideal para imersão no banho de zinco (pote). Após este controle de temperatura, a tira é direcionada através de um túnel de imersão eletromecânico, chamado de snout, para o banho de metal fundido, conforme mostrado na figura 35, no qual a camada metálica é aplicada. Esta figura apresenta detalhes um pote com banho de zinco. Pode-se ver o posicionamento do rolo submerso, a navalha de ar e os eletrodos de aquecimento do banho.

Figura 35 - ilustração de um pote com o banho de zinco num processo de zincagem por imersão a quente. Pode-se visualizar o posicionamento do rolo submerso, a navalha de ar e os eletrodos de aquecimento do banho

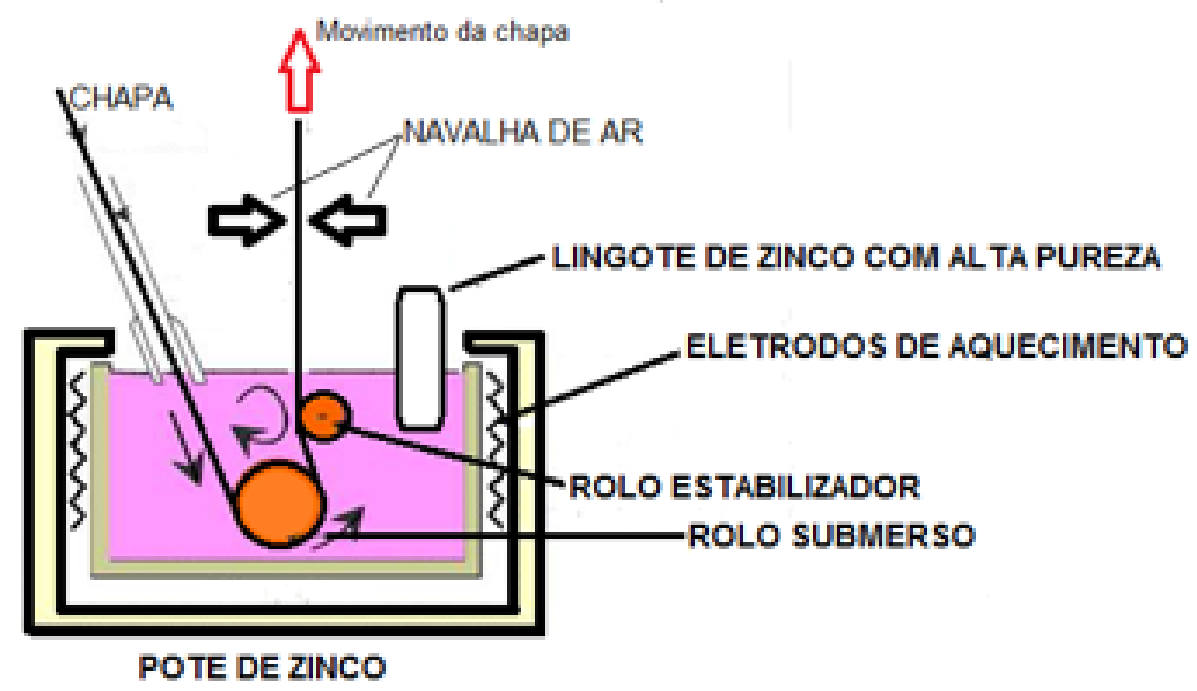

Fonte: autores

O zinco, também atua de uma maneira especial para proteger o aço em caso de superfície "descoberta" por arranhões, furos e descontinuidades. Essa atuação se deve ao fato do zinco ser um metal eletroquimicamente mais ativo que 0 ferro. Neste caso, ocorre a chamada Proteção Catódica também conhecida como proteção de sacrifício. A figura 36 apresenta uma amostra de aço revestido com zinco que sofreu um risco superfície e, em anexo, uma tabela com os potenciais eletroquímicos de alguns elementos químicos. Pode-se observar, na figura, que o zinco sofre corrosão em favor do ferro. 
Figura 36 - amostra de aço revestido com zinco com um risco na superfície (a) e tabela com potenciais eletroquímicos de alguns elementos químicos (b)

Zn (anedo)

Aço (catodo)

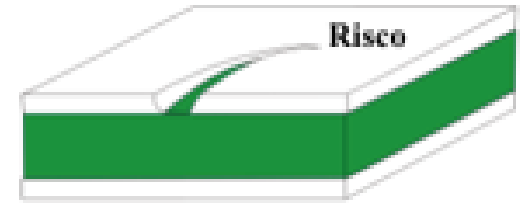

(a)

\begin{tabular}{l|l}
\hline los mesilico & Posencial \\
\hline $\mathrm{K} *$ & $+2,96$ \\
$\mathrm{Ca}^{2 *}$ & $+2,90$ \\
$\mathrm{Zn}^{2-}$ & $+0,76$ \\
$\mathrm{Fe}^{2+}$ & $+0,44$ \\
\hline $\mathrm{H} \mathrm{H}^{*}$ & 0,00 (ref.) \\
\hline $\mathrm{Cu}^{+}$ & $-0,47$ \\
$\mathrm{Ag}^{*}$ & $-0,80$ \\
$\mathrm{Pt}^{*}$ & $-0,86$ \\
$\mathrm{Au}^{*}$ & 50 \\
\hline
\end{tabular}

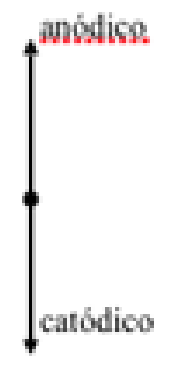

PRINCIPAIS

\section{APLICAÇÕES}

DOS PRODUTOS

GALVANIZADOS POR IMERSÃO A QUENTE
_. Equipamentos agrícolas;

_ Dutos de aparelhos de ar condicionado; _ Industria automobilística (carroceria de ônibus, automóveis e caminhões);

_. Equipamentos de ar condicionado;

_ Parte estrutural de painéis;

_ Geladeiras e freezers.

_ Silos para armazenagem de produtos alimentícios;

imersão a quente

Tabela 8 - Tipos de revestimentos por imersão a quente

$$
\text { TIPO DE REVESTIMENTO Massa }(\mathrm{g} / \mathrm{m} 2) \text { Microns }(\mu \mathrm{m})
$$

\begin{tabular}{ccc}
$Z$ & 60 & 10 \\
\hline$X$ & 85 & 14 \\
\hline A & 160 & 24 \\
\hline B & 250 & 36 \\
\hline C & 315 & 47 \\
\hline D & 390 & 58 \\
\hline E & 450 & 65 \\
\hline F & 510 & 74 \\
\hline$G$ & 580 & 86
\end{tabular}

Os revestimentos mais espessos são aplicados onde se exige alta resistência a oxidação como, por exemplo: calhas de drenagem, telhado e silos.

Ao contrário, na indústria automotiva, onde a conformabilidade e soldabilidade são requisitos fundamentais e primordiais, são utilizados revestimentos mais leves (ex.: revestimento tipo " $\mathrm{x}$ "). 


\section{ACABAMENTO DAS CHAPAS ZINCADAS POR IMERSÃO}

\section{Bordas}

As bordas podem ser fornecidas naturais de laminação a frio (tendo sido aparadas anteriormente nas linhas de decapagem) ou aparadas nas linhas de acabamento.

Obs: A apara nas linhas de acabamento é importante quando houver necessidade de tolerância restritiva, ou seja, mais "apertada" na dimensão da largura do produto.

\section{Tipos de revestimento}

São divididos em cristais normais, cristais minimizado, revestimento liso e revestimento extra liso.

\section{Cristais Normais}

Apresentam-se com o formato de cristais que são chamados de "Flores de Zinco", as quais são formadas durante a solidificação do revestimento.

\section{Cristais Minimizados}

Consistem de revestimento formado por cristais muito menores. São obtidos por tratamento antes da solidificação do zinco. Ocorre uma inibição da formação dos cristais. Apresenta uma superfície fosca e acabamento mais homogêneo.

\section{Liso}

É um acabamento com cristais normais após passagem pelo laminador de encruamento.

\section{Extra Liso}

É um acabamento com cristais minimizados após passagem pelos cilindros do laminador de encruamento.

A figura 37 é uma apresentação dos principais tipos de revestimentos de uma linha de zincagem por imersão a quente, ou seja, liso, minimizado e cristais normais.

Figura 37 - principais tipos de revestimentos de uma linha de zincagem por imersão a quente (liso, minimizado e cristais normais)

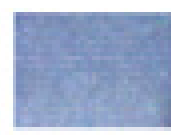

acabamento liso

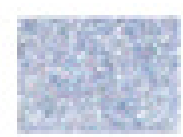

acabamento com cristais minimizados

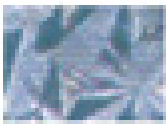

acabamento com cristais normais 


\section{GALVANNEAL}

É um produto galvanizado composto por uma chapa fina de aço, com baixo teor de carbono, revestida em ambas as faces com uma camada de liga Fe-Zn e zinco, por imersão a quente.

A camada de liga (Fe-Zn) é formada logo após a saída do pote fundido de zinco através de um tratamento térmico com rigoroso controle de temperatura. O teor de ferro na camada revestida varia, geralmente, entre $9,0 \%$ e $12,0 \%$. O revestimento tem uma aparência "fosca" quando comparada com aquela do produto zincado. Esta superfície fosca é excelente para pintura. Pode ser pintada sem a aplicação de pré-tratamento. Aliás, ela é recomendada somente em aplicações destinadas a Tabela 9 - Revestimentos aplicados aos produtos Galvanneal

\begin{tabular}{cccc} 
DESIGNAÇÃO DO REVESTIMENTO & Massa $(\mathbf{g} / \mathbf{m} \mathbf{2})$ & Microns $(\mu \mathbf{m})$ \\
\hline 180 & 180 & 11 \\
\hline 120 & 120 & 9,0 \\
\hline 100 & 100 & 7,0 \\
\hline 75 & 75 & 5,0
\end{tabular}

(a) relativo as 2 faces / (b) relativo a 1 face

\section{GALVALUME ${ }^{\circledR}$}

É uma chapa fina de aço, com baixo teor de carbono, revestida em ambas as faces com a liga 55\%Al-Zn, aplicada por imersão a quente, similar ao processo convencional.

Este produto combina a durabilidade do alumínio com a proteção galvânica do zinco, oferecendo excelente resistência à corrosão em atmosferas, tanto marinha quanto industrial e resistência à oxidação pintura. É amplamente utilizada na indústria automotiva, cuja espessura típica de revestimento é de 7,0 $\mu \mathrm{m}$ com massa de revestimento de $50 \mathrm{~g} / \mathrm{m} 2$.

Outros atributos do revestimento de liga Zn-Fe em comparação ao revestimento de zinco puro são:

_ O Galvaneel é soldado mais facilmente que o de zinco puro;

_ O Galvaneel é mais duro e, consequentemente, mais resistente aos danos de manuseio e manufatura.

A tabela IX apresenta os tipos de revestimento aplicados nas chapas revestidas com a liga Zn-Fe, ou seja, nos produtos Galvanneal. 
tência à corrosão a alta temperatura, como por exemplo, os canos de descarga dos automóveis, conhecido como "silenciosos".

A tabela $\mathrm{X}$ apresenta os tipos de reves- timento aplicados nos produtos Galvalume ${ }^{\circledR}$. Na tabela, pode-se observar que tanto a designação quanto a massa de revestimento são relativos as 2 faces da chapa revestida.

Tabela 10 - Revestimentos aplicados aos produtos Galvalume ${ }^{\circledR}$

\begin{tabular}{cccc} 
DESIGNAÇÃO DO REVESTIMENTO & Massa $(\mathbf{g} / \mathbf{m} 2)$ & Microns $(\mu \mathbf{m})$ \\
\hline 180 & 180 & 24 \\
\hline 165 & 165 & 22 \\
\hline 150 & 150 & 20 \\
\hline 75 & 75 & 5,0 \\
\hline
\end{tabular}

(a) relativo as 2 faces / (b) relativo a 1 face

\section{PROCESSO \\ DE ZINCAGEM ELETROLÍTICA}

O processo de zincagem eletrolítica (eletrogalvanização) ocorre durante a deposição do zinco em tanques apropriados a uma temperatura de aproximadamente $50^{\circ} \mathrm{C}$, não alterando, portanto, as propriedades mecânicas do material base.

Durante o processo eletrolítico, o zinco é dissolvido num tanque contendo uma solução ácida de sulfato de zinco. Neste referido tanque são posicionados eletrodos com polarização positiva de forma a criar um caminho do zinco presente na solução aderindo à tira a qual está polarizada negativamente.

A etapa de recobrimento se faz pelo escoamento do eletrólito sobre as superfícies da tira de aço por um determinado tempo que é definido pela velocidade do processo de tratamento. Os íons positivos de zinco presentes no eletrólito são reduzidos a zinco metálico, depositando-se sobre as superfícies da tira.

\section{ELETROZINCADO}

É uma chapa fina de aço, com baixo teor de carbono, revestida em ambas as faces com zinco, aplicado pelo processo de eletrodeposição. Tem aplicações em vários setores, destacando-se:

_ Indústria automobilística (painéis internos e externos, portas, pára-lamas, radiadores, ar condicionado e filtros de óleo);

- Indústria de eletrodomésticos (refrigeradores, lavadoras, secadoras, e freezers);

_ Indústria de eletroeletrônicos (CD players, rádios e amplificadores).

De um modo geral, ele pode ser usado em qualquer aplicação onde é usado o zincado comum, mas ele é utilizado somente quando se requer uma menor resistência à corrosão. 
MORFOLOGIA E

\section{ESPESSURA DA CAMADA}

O revestimento é do tipo zinco puro. Sua morfologia é caracterizada por finos cristais de zinco puro depositados sobre a superfície do aço, formando uma fina camada uniforme e bastante aderente. O resultado é um revestimento dutil e homogêneo que proporciona um excelente aspecto superficial. Ele permanece intacto mesmo quando submetido à severas deformações.

A espessura do revestimento - medida como peso - que vai de 10 a $70 \mathrm{~g} / \mathrm{m} 2$ com espessura de aproximadamente $3,6 \mu \mathrm{m}$ (considerando uma face), é um importante fator na aplicação de chapas eletrozincadas. O peso do revestimento é necessário para uma aplicação específica. Quanto mais espesso a camada, melhor a vida do produto quando exposta a um ambiente corrosivo. Entretanto, itens tais como - estampagem e soldagem - devem ser levados em consideração.

\section{REFERÊNCIAS}

[1]. ArcelorMittal Vega (2010). Ajuste de posicionamento da tromba.

[2]. ASTM; Standard Test Method for Weight of Coating on Zinc-Coated (Galvanized). Annual Book of American Society for Testing and Materials: 1993.

[3]. Chen, D. Adaptive control of hot-dip galvanizing. Automatica: Vol. 31, p. 715-733 (1995).

[4]. CIMM - CENTRO DE INFORMAÇÃO
METAL MECÂNICA. Catálogo de Produtos Disponível em: www.cimm.com.br. Acesso em 20 de março de 2015.

[5]. CSN - COMPANHIA SIDERURGICA NACIONAL. Catálogo de Produtos. Disponível em: http://www.csn.com.br. Acesso em 8 de abril de 2015.

[6]. Fernandes, J. N., Kobayashi, M., Reis, D. T.; Linha de Galvanização por Imersão a Quente da Unigal, Congresso anual da ABM: p. 414-419, 2000.

[7]. PINTO JUNIOR, D. M. Apostila de Curso sobre processo de Zincagem por Imersão. Abril/1994. Companhia Siderúrgica Nacional - CSN.

[8]. USIMINAS. Catálogo Usiminas Hot-Dip Galvanized Steel, 2000.

[9]. USS - UNITED STATE STEEL CORPORATION. Catálogo de Produtos. Disponível em: https://www.ussteel.com/uss/portal. Acesso em 8 de abril de 2015. 


\section{EXERCÍcIOS}

1. Como é conhecida a proteção propiciada pelo zinco?

2. Descreva, resumidamente, o que é a corrosão.

3. Qual a finalidade da adição do aluminio no banho fundido de zinco?

4. Qual a finalidade da adição de chumbo, ou antimonio, no banho fundido de zinco?

5. Além do revestimento de zinco puro, quais os outros tipos de produtos zincados existem?

6. Em que se baseia os pedidos de produtos zincados aos fornecedores?

7. Quais são as principais aplicações dos produtos galvanizados por imersão a quente?

8. Quais são os tipos de revestemto existem?

9. Que são cristais normais?

10. Que são cristais minimizados?

\section{RESOLUÇÃO DOS EXERCÍCIOS}

1. A proteção propiciada pelo zinco é conhecida como proteção de sacrifício. Isto porque a camada superficial de zinco depositada, se sacrifica para proteger o substrato que é o aço. Em outras palavras, os metais mais redutores se corroem em lugar dos menos redutores.
2. A corrosão é o fenômeno de deterioração com perda de material devido a modificações químicas e eletrônicas que ocorrem por reações com o meio ambiente. Ela propicia a falha direta dos metais quando estão em algum tipo e serviço e os torna suscetíveis de romper por algum outro mecanismo.

3. O alumínio, com percentual entre 0,20\% e 0,30\%, é adicionado ao banho de zinco fundido para controlar a taxa de crescimento de uma camada da liga (zona de ligação entre o aço e o revestimento de zinco). Ele aumenta drasticamente a adesão do revestimento o que permite a moldagem rigorosa da chapa revestida.

4. O revestimento pode conter uma pequena quantidade de chumbo e/ou antimônio para o desenvolvimento de brilho. Quase todos os produtos galvanizados não contêm chumbo, e quando contém, o chumbo é menor que 0,03\%.

5. Além do revestimento com 100\% de zinco, existem diferentes tipos de revestimentos com zinco na composição: Galvanneal (90\% Zinco-10\% Ferro), Alumínio-Zinco (55\% Alumínio- e 65\% Zinco), dentre outros. É importante destacar que o Galvanneal é muito utilizado na indústria automobilística em decorrência, principalmente, da característica de muito boa soldabilidade.

6. A maneira mais comum de fazer pedidos de chapas de aço revestidas aos fornecedores de aço é se referindo às Normas ASTM. Estas normas, escritas 
por comitês de redação de normas voluntários dentro da organização internacional ASTM, abrangem todos os detalhes relacionados a pedidos de chapas de aço revestidas. Estes detaIhes incluem: tipo de revestimento, peso da camada de revestimento, acabamento superficial, resistência do substrato, dimensões do aço base, tais como espessura e largura e tolerâncias (dimensões e espessura do revestimento).

7. As principais aplicações dos produtos galvanizados por imersão a quente, são:

- Telhas para coberturas, principalmente galpões e residências;

_ Silos para armazenagem de produtos alimentícios;

_ Equipamentos agrícolas;

_ Dutos de aparelhos de ar condicionado;

_ Industria automobilística (carroceria de ônibus, automóveis e caminhões);

_ Equipamentos de ar condicionado;

_ Parte estrutural de painéis;

_ Geladeiras e freezers.

8. Os tipos de revestimento são divididos em cristais normais, cristais minimizado, revestimento liso e revestimento extra liso.

9. Os Cristais Normais apresenta-se com o formato de cristais que são chamados de "Flores de Zinco", as quais são formadas durante a solidificação do revestimento.

10. Cristais Minimizados consiste de um revestimento formado por cristais muito menores. É obtido por tratamento antes da solidificação do zinco. Ocorre uma inibição da formação dos cristais. Apresenta uma superfície fosca e acabamento mais homogênio. 


\section{ESTAMPABILIDADE DE AÇOS}

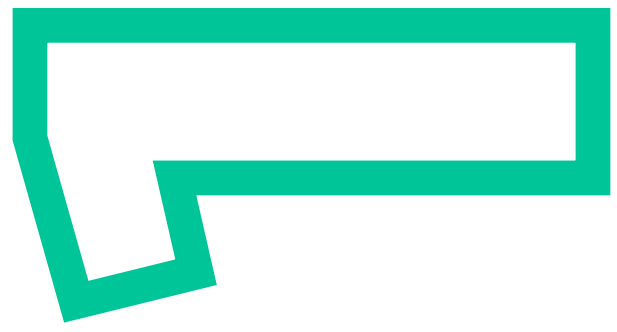

Fala sobre:

_ Introdução

- Processos de estampagem

- Corte

- Entalhe

- Funcionamento

- Dobra

- Embutimento

_ Lata de duas peças

_ Variáveis que influenciam

_ Principais aplicações

_ Referências Bibliográficas

_ Aspectos de qualidade

_ Exercícios resolvidos 


\section{INTRODUÇÃO}

Estampagem pode ser definido como um processo de conformação mecânica, geralmente realizado a frio, que engloba um conjunto de operações, através das quais uma chapa plana é submetida a transformações de forma a adquirir uma nova forma geométrica. A deformação plástica é realizada com a utilização de prensas de estampagem, com o auxílio de dispositivos especiais denominados: estampos (daí o nome estampagem) ou matrizes.

Os processos de estampagem são amplamente utilizados na indústria automotiva, onde se necessita alto índice de produção, baixo índice de sucateamento e uma garantia de dimensões das peças estampadas.

A estampagem pode ser simples, quando se executa uma só operação, ou combinada, quando se executa várias operações.

Normalmente, são utilizados com boas características de estampabilidade, tais como: aços de baixo carbono, aços inoxidáveis com boa plasticidade, alumínio e suas ligas e materiais não ferrosos.

Devido as suas características, este processo de fabricação é apropriado, preferencialmente, para alta produção, normalmente em série, obtendo-se vantagens, tais como:

_ Alta produtividade.

_ Baixo custo de produção.

- Acabamento bom não necessitando acabamento posterior.
_ Aumento da resistência mecânica das peças.

Vale destacar a desvantagem deste processo que é o elevado custo do ferramental. Neste caso, o investimento só se justifica para projetos com linhas dotadas de alta produção como é o caso das indústrias automotivas.

Basicamente, uma peça (perfil) é produzida a partir de um disco plano, chamado de blanck, através da tração e contração das dimensões de todos os seus elementos de volume nas três direções principais mutuamente perpendiculares. O perfil obtido é o resultado de integração de todas as distensões e contrações locais dos elementos de volume.

Basicamente são 5 (cinco) categorias obtidas a partir conformação de chapas finas com qualidade de estampabilidade:

_ Peças simplesmente curvas;

_ Peças flangeadas, com flanges estirados e flanges contraídos;

_ Peças com seções curvas;

_ Peças com leves embutimentos, como pratos e latas de atum;

_ Peças com embutimentos profundos, como por exemplo as latas de "duas peças".

\section{PROCESSO DE ESTAMPAGEM}

Basicamente o processo de estampagem se divide em: corte, entalhe, puncionamento, dobra e embutimento (repuxo). 
Operação de corte

Consiste em separar uma chapa, com dimensões determinadas. É feito através de duas laminas que se movimentam como na figura 38, onde pode-se visualizar as lâminas da prensa e a folga entre elas.

Figura 38 - representação de uma operação de corte numa prensa onde pode se visualizar as laminas e a folga entre elas
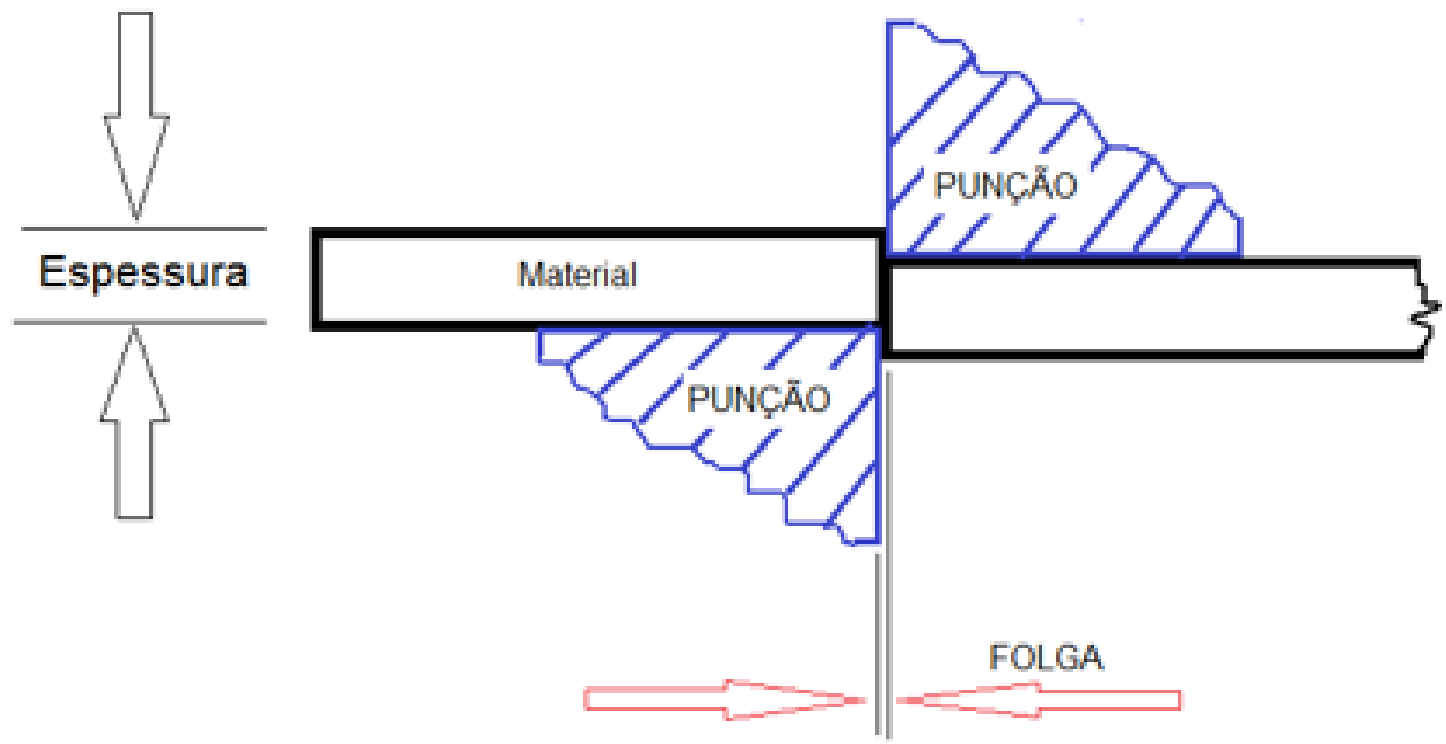

Fonte: autores

São operações realizadas por intermédio de uma prensa que exerce pressão sobre uma chapa apoiada numa matriz. O material (chapa) é intensamente deformado plasticamente até o ponto em que se rompe nas superfícies em contato com as lâminas. A fratura se propaga, então, promovendo a separação total do material. A profundidade que o punção deve ser penetrado no material a ser cortado está diretamente relacionado com a ductilidade do material. Se o material for "frágil", pequena profundidade é suficiente para o corte total. No caso de materiais muito dúcteis, esta penetração pode ser ligeiramente superior à espessura da chapa.

A folga existente entre o punção e matriz, ou entre as lâminas, é uma variável importante nas operações de corte.
Vale destacar que existe, no equipamento, o chamado anti-rugas para evitar formação de ondulações, o que comprometeria a qualidade das peças.

\section{Operação de entalhe}

Pode-se considerar como um corte parcial, ou seja, quando há corte sem separação total da peça. A figura 39 apresenta detaIhes da operação de entalhe.

Figura 39 - detalhes da operação de entalhe
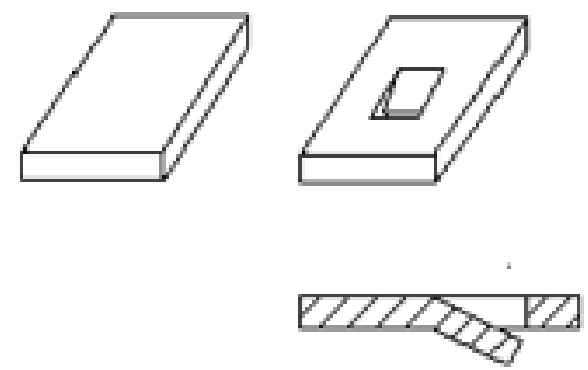

Fonte: autores 
Tecnología siderúrgica

Operação de puncionamento

É a obtenção de peças geométricas por meio de punção e matriz através de impacto em que ocorre separação total da peça. A figura 40 apresenta detalhes de uma operação de puncionamento.

Figura 40 - representação esquemática dos detalhes de uma operação de puncionamento

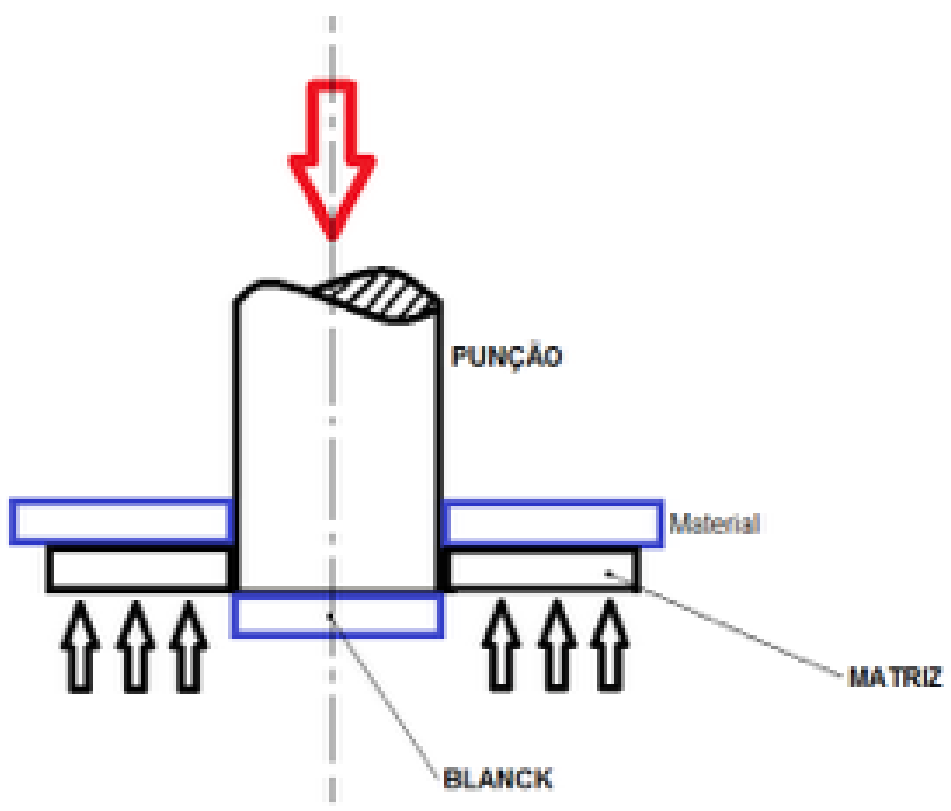

Fonte: autores

Operação de dobra

Como o próprio nome já diz, consiste em obter peças através de uma ou mais dobras, a partir de uma chapa plana em que utiliza-se, também, o estampo (figura 41).

Figura 41 - dobra a partir de uma chapa plana
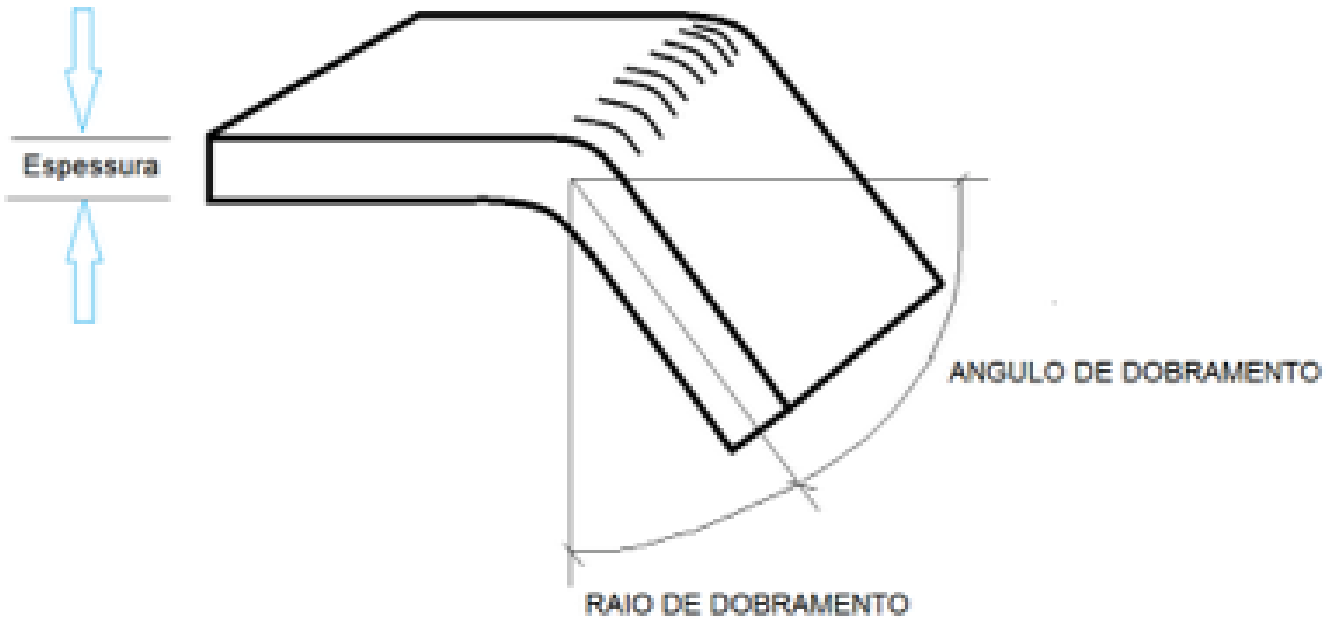

Fonte: autores

Operação de embutimento (repuxo)
Esta operação tem como finalidade produzir peças com formato de recipiente 
(copo), caixas e tubos. São obtidos pela conformação das chapas, a partir de golpes de prensa onde são utilizados ferramental (punção, matriz e anti-rugas) especial denominado estampo de repuxo. A seguir, são relacionadas algumas definições importantes com relação ao embutimento.

O punção é o elemento do ferramental que é responsável pela perfuração na chapa. Dependendo do espessura e da cavidade a ser feita, a força a ser aplicada neste equipamento pode chegar a toneladas.

Como um melhor exemplo de embutimento profundo, muito utilizado nos dias atuais, não podemos esquecer de citar a produção da lata de duas peças fabricadas em aço. Este novo produto da indústria siderúrgica foi chamado de aço DWI (Draw and Wall Ironing). É um tipo de aço que deve ser bem mais limpo internamente que aquele resultante nos processos de refino tradicionais (Aciaria LD), seguido do processo de metalurgia de panela e refino secundário.

Além disso, verificou-se que devido ao processo de estampagem sofrido e ao afinamento da parede da lata, que chega a atingir espessuras da ordem de 0,10 milímetros.

As propriedades mecânicas do aço devem ser adequadas e bem controladas para atender a fabricação. As composições químicas são dotadas de especificações mais estreitas, ou seja, com faixas mais apertadas. Deve-se ter: um ótimo controle das temperaturas de processo na laminação a quente - temperaturas de acabamento e de bobinamento, taxas de redução a frio adequadas, controle rigoroso do ciclo de recozimento e passe adequado no processo de laminação de encruamento. Estas variáveis são vitais para garantia da fabricação deste produto. Outro fator relevante que deve ser comentado é a importância do controle de espessura deste material, já que as deformações sofridas no processo de laminação, principalmente a frio, propiciam variações de espessuras que comprometem o processo. Para garantia de atendimento, foram desenvolvidos laminadores de tiras a frio com maior precisão de espessura, baseados em controle automático em feedback com leitura a raios- $x$ em todas as cadeiras de laminação.

Ainda com relação a produção de embalagens de duas peças em aço, no caso do Brasil, a única empresa com capacidade de produção para atendimento deste mercado é a Companhia Siderúrgica Nacional (CSN).

O processo de fabricação de lata de duas peças inclui diversas etapas. Uma das mais importantes etapas é a conformação do corpo da lata e o percentual de redução da parede da mesma. Esta redução é bastante severa, o que exige do produto uma considerável uniformidade, tanto dimensional quanto limpeza interna oriunda dos processos de refino. Nesta etapa do processo, problemas de variação da espessura para menos em relação ao valor alvo podem provocar falta de material durante o embutimento gerando lata curta; variações acima do valor alvo conduzem a excesso de material gerando latas compridas, ou seja, de maior comprimento.

Abaixo são resumidas as etapas do 
processo de fabricação de latas de duas peças. A perfeita fabricação de uma lata de duas peças depende de diversas variáveis, sendo de suma importância à variação de espessura ao longo da bobina. A tolerância de espessura se torna crítica, especialmente na etapa determinada como bodymaker. Nesta etapa, as paredes do copo são estiradas, o diâmetro e a espessura da lata são reduzidos até atingir as medidas especificadas, formando o corpo da lata.

\section{ETAPAS DO PROCESSO DE FABRICAÇÃO DAS LATAS DE DUAS PEÇAS}

Estampagem da Lata e Formação do Fundo:

1. Alimentação da Bobina;

2. Corte e Estampagem do Copo;

3. Corte do excedente;

4. Lavagem e Secagem;

5. Revestimento Básico Externo (Base coater);

6. Secagem, Forno de Pinos;

7. Decoração;

8. Secagem, Forno de Pinos;

9. Revestimento Interno;

10. Cura do Verniz;

11. Formação do Pescoço;

12. Formação do Flange;
13. Revestimento do Fundo da Lata;

14. Light Tester - Detector de furos;

15. Inspeção de Câmeras;

16. Paletizadora, Cintadora e Filmadora;

As etapas 2, 3, 11 e 12, são operações de estampagem. A mais crítica, em que se concentra o maior índice de rejeito das latas, é na etapa 12 (formação do flange). 0 aço necessita estar em condições de excelentes no que diz respeito à limpeza interna.

A perfeita fabricação de uma lata de duas peças depende de diversas variáveis, sendo de suma importância a variação de espessura ao longo da bobina. A tolerância de espessura se torna crítica, especialmente na etapa determinada como bodymaker. Nesta etapa, as paredes do copo são estiradas, o diâmetro e a espessura da lata são reduzidos até atingir as medidas especificadas, formando o corpo da lata.

A seguir são apresentados (Quadro 4) alguns exemplos de aços adequados para aplicação em estampagem extra profunda. 
Quadro 4 - Alguns exemplos de aços com qualidade de estampagem, bem como as respectivas normas ABNT

\begin{tabular}{cccc} 
PRODUTO & GRAU ESTAMPAGEM & NORMA & ESPESSURA (mm) \\
Chapa Fina Laminada a Frio & Qualidade Comercial (QC), & NBR06658 & 0,60 \\
\hline Chapa Fina Laminada a Frio & $\begin{array}{c}\text { Estampagem Extra Profunda } \\
\text { (EEP) }\end{array}$ & NBR05915 & 0,60 \\
\hline $\begin{array}{c}\text { Chapa Fina Eletrogalvani- } \\
\text { zada EG) }\end{array}$ & $\begin{array}{c}\text { Estampagem Extra Profunda } \\
\text { para peça crítica (EEP-PC) }\end{array}$ & NBR05915 & 0,55 \\
\hline
\end{tabular}

Fonte: catálogo da ABNT

\section{REFERÊNCIAS}

[1]. BRESCIANI FILHO, Ettore et al. Conformação plástica dos metais. 5.ed. São Paulo: Unicamp, 1997.

[2]. CAO, Jian et al. Next generation stamping dies: controllability and flexibility. Robotics and Computer Integrated Manufacturing, v. 17, p. 49-56, 2001.

[3]. CHIAVERINI, Vicente. Tecnologia mecânica. São Paulo: McGraw Hill, 1977. v.1

[4]. COMPANHIA SIDERÚRGICA NACIONAL - CSN. Disponível em: <www. csn.com.br>. Acesso em: 20 abr. 2015. 


\section{EXERCÍCIOS}

1. Defina estampagem.

2. Descreva, resumidamente, como é produzida uma peça através da estampagem.

3. Dê algumas vantagens do processo de estampagem.

4. Quais são as categorias englobadas pelo processo de estampagem?

5. Em que consiste uma operação de corte?

6. Em que consiste uma operação de dobra?

7. Em que consiste uma operação de embutimento?

8. Porque a fabricação de latas de 2 peças

é um bom exemplo de embutimento profundo?

9. Quais são as etapas de uma linha de produção de latas de 2 peças? 


\section{TREFILAÇÃO DE AÇOS}

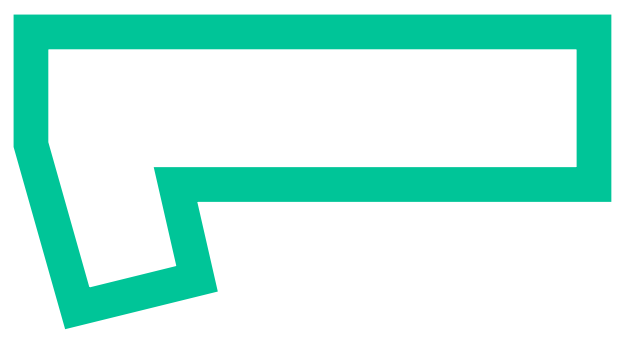

\section{Fala sobre:}

_ Introdução

_ Processos de trefilação

_ Tipos de arame

_ Variáveis que influenciam

_ Principais aplicações

_ Referências Bibliográficas

_ Aspectos de qualidade

_ Exercícios resolvidos 


\section{INTRODUÇÃO}

A fabricação de arames é feita a partir de um material de aço denominado Fio-Máquina. Este é um vergalhão de aço fabricado por laminação e armazenado na forma de bobina. Ele é usado na produção de arames, por meio de um processo de diminuição de diâmetro denominado trefilação.

Arames e fios são matérias-primas para fabricação de outros produtos, por exemplo, a partir deles pode-se fabricar: pregos, parafusos, redes de aço, alambrados, arame farpado, cordas de piano, cabos de elevador, cabos de içamento em geral.

No caso de cabos de elevador, estes são constituídos pela união de vários fios de arame, pois se alguns deles estiverem rompendo, podem ser verificados nas inspeções periódicas e trocados (por este motivo é importantíssimo realizar inspeções periódicas em elevadores e todo tipo de cabo que trabalha sob alta responsabilidade).

Há alambrados que são fabricados a partir de arames. Outros arames de uso especial são os farpados, que são utilizados em fazendas. Nos lares, as donas de casa têm contato com arames nos varais para secagem de roupas, nos carrinhos de feira em muitos outros empregos que se encontram no interior das máquinas de lavar roupa, dos liquidificadores, enceradeiras, veículos e muitos outros equipamentos.

\section{O PROCESSO}

Os arames são fabricados na bitola ou diâmetro da seção transversal especifi- cada a partir do fio máquina.

Fio máquina é um material produzido nas siderúrgicas de material não plano. Estas fabricam o fio máquina a partir de tarugos que podem ser provenientes de processo de lingotamento contínuo.

Um exemplo disso é quando um tarugo de seção quadrada de 120 por 120 mm pode passar na laminação para diminuir sua espessura e posteriormente pode ser aquecido e passar por uma fieira numa máquina trefila.

Fieira é uma peça de altíssima resistência que pode ser produzida a partir de óxidos, que são conformados num formato interno de funil com uma dimensão maior de entrada e uma menor de saída.

O fio de aço será puxado pelo lado menor fazendo com que o fio máquina diminua sua espessura chegando à espessura da saída da fieira, que é aquela do arame desejado. O produto se estica e, à medida que é fabricado, ele é bobinado para se economizar espaço.

A figura 42 ilustra, de uma forma esquemática, as tensões que ocorrem durante o processo de trefilação. 
Figura 42 - ilustra as tensões que ocorrem durante o processo de trefilação

Fonte: autores

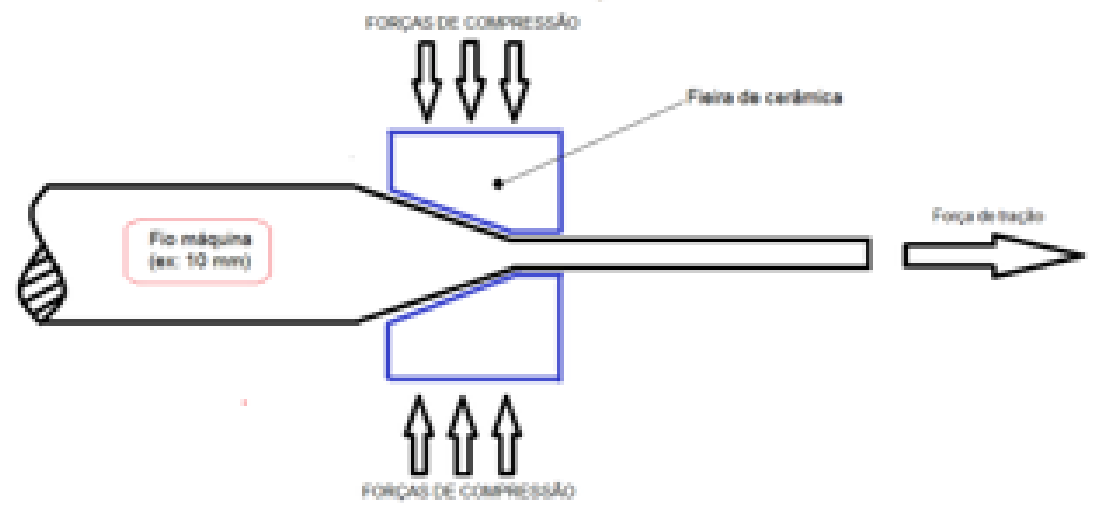

Pode-se observar, na figura, que a fieira atua como uma espécie de funil reduzindo, consequentemente, o diâmetro do fio máquina. Tal afunilamento, que ocorre na fieira, é realizado numa região que contém material cerâmico extremamente duro, que é denominado Widia, ou seja, carboneto de tungstênio.

O material utilizado para a parte ativa da fieira pode ser de:

a) Carbonetos sinterizados (sobretudo WC - Widia);

b) Diamante $(p /$ fios finos ou de ligas duras);

c) Pó de óxidos metálicos sinterizados;

d) Aços de alto $\mathrm{C}$ revestidos de $\mathrm{Cr}$;

Figura 43 - desenho esquemático de uma fieira

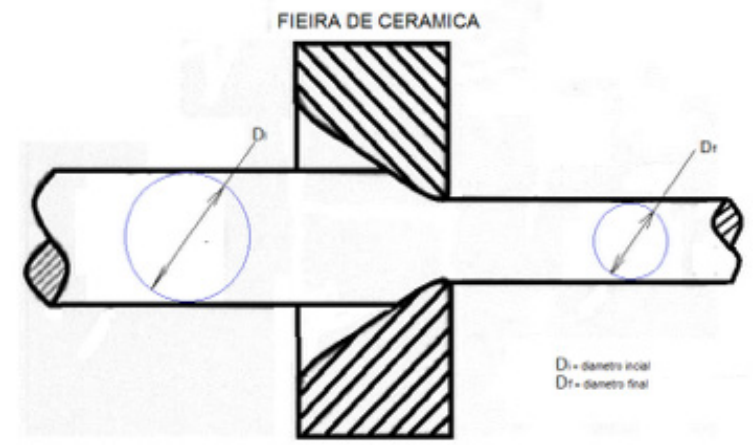

e) Aços especiais (Cromo-Molibdênio ou Cromo-Vanádio);

f) Ferro fundido branco.

Outro aspecto interessante é o das forças que ocorrem na trefilação: por um lado, na saída do produto se realiza a tração enquanto que no interior da fieira, ocorrem forças de compressão.

O processo de fabricação na trefilaria que é por tração do fio máquina difere do processo que ocorre na extrusão. Nesta, a peça de aço é comprimida contra o molde e só existe uma saída que é a aquela que possui um perfil, por exemplo, de cantoneira, perfilado em I, perfilado em $\mathrm{T}$ ou outro semelhante (figura 43).

Fonte: autores 


\section{TIPOS DE ARAME}

Arames de baixo carbono (estes são empregados em aplicações de menor responsabilidade): ovalado, farpado, recozido (os arames recozidos e normalizado são indicados para serem aplicados na fabricação de arames lisos e farpados, arames para telas, parafusos, rebites, etc.) e galvanizado (recebe uma camada superficial de zinco para proteção contra corrosão).

Arames de médio carbono são empregados em molas e cabos de pequena responsabilidade.

Arames de alto carbono sem tratamento térmico são indicados para serem usados como eletrodos de solda.

Arames de alto carbono com tratamento térmico podem ser utilizados para molas de alta responsabilidade, corda de piano e de instrumentos musicais.

Arames de alto carbono patenteado - o denominado patenteamento - é um tratamento que visa obtenção de uma estrutura microscópica de perlita fina ou bainita. Esta confere ao aço, alta resistência aliada a tenascidade.

Normalmente, a espessura de um arame ou fio de aço, não se usa o padrão American Wire Gauge - AWG, pois este é voltado para não-ferrosos, mas nada impede de se usar este padrão de bitola para este material.

\section{DICAS PARA OS ENGENHEIROS, TECNÓLOGOS, TÉCNICOS E PESSOAL DE OPERAÇÃO}

_ O pessoal que trabalha nessa área tem que fazer a regulagem do equipamento e o controle do material de saída.

_ Uma das formas mais simples de verificação da dimensão do material de saída é por meio do uso de pedaços de madeira que são comprimidos contra o arame que está saindo da máquina e segue para ser bobinado.

_ Encostando-se a peça de madeira ocorre a marcação nela. Fazendo-se a medição da marcação realizada na madeira, pode-se ter o diâmetro do produto que está sendo fabricado.

- Durante a fabricação pode ocorrer o rompimento do arame e este pode ser soldado e continuar a ser puxado nas bobinas.

_ Outro aspecto importante é que o material fio máquina que vai para a trefilaria tem que estar recozido, por meio do processo de tratamento térmico de recozimento ele se torna um material macio e com isso, facilita-se o processo de deformação.

_ Quando o material se deforma, ele passa ao estado encruado e pode adquirir novamente alta resistência. 


\section{EXERCÍCIOS}

1. Cite pelo menos três produtos do mercado feitos com arame ou a partir de arame.

2. Descreva como pode ser feita a medicação do calibre do produto que está saindo da fieira, durante o processo de fabricação.

3. Em que estado de processamento do material de aço, uma bobina de Fio Máquina tem que ir para a trefilaria para se transformar em arame de diâmetro menor?

4. De que material cerâmico extremamente duro e resistente é construído o interior da fieira que fica na região onde ocorrerá a diminuição do diâmetro no interior da fieira?

5. Cite pelo menos três regiões ou ângulos de uma fieira de trefilação,

6. Como é a constituição de um cabo de elevador?

7. Descreva o estado de forças triaxial que se forma na trefila?

8. Como o processo de trefilaria difere daquele de extrusão de aços?

9. O fio máquina é produzido por meio de que processo?

10. Cite pelo menos três materiais possíveis de seu utilizar na construção de fieiras. 


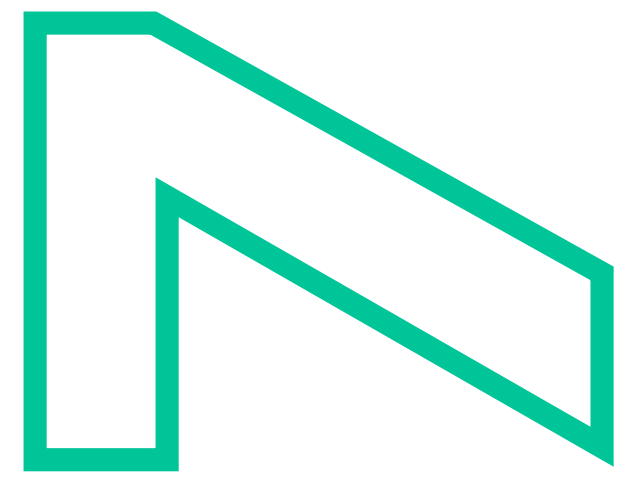

\section{ENSAIOS MECÂNICOS EM AÇOS}

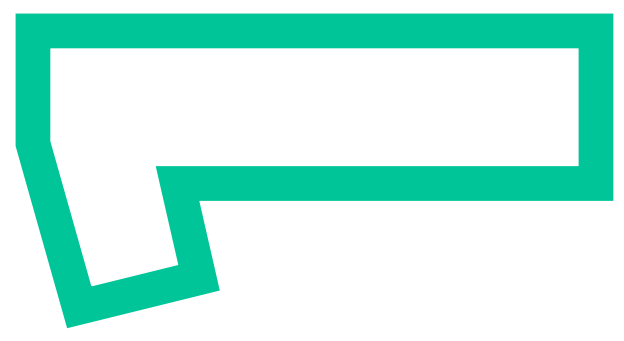

\section{Fala sobre:}

_ Introdução

_ Tipos de ensaios

_ Ensaios usuais (tração, dureza, etc)

_ Variáveis que influenciam

_ Uso de normas

_ Referências Bibliográficas

_ Aspectos de qualidade

_ Exercícios resolvidos 


\section{INTRODUÇÃO}

Os ensaios mecânicos nos aços permitem verificar se eles atendem ou não as especificações das normas para alguma determinada aplicação. Um exemplo é: um aço para grade ou portão de casa não precisa ter as mesmas especificações que outro que será utilizado para botijões de gás e estes não precisam ter a qualidade de um aço de alta resistência utilizado, por exemplo, nos reatores de uma usina nuclear.

As qualidades diferentes são obtidas por meios de processos diferentes de fabricação. Os processos diferentes têm custos diferentes e produtos diferentes.

É preciso verificar a qualidade dos produtos dos processos para saber se atenderão ou não as aplicações a que se destinam e caso não atendam os materiais podem ser desviados para aplicações menos nobres ou que tenham menos exigências em suas especificações.

Enquanto a Química está relacionada com as reações entre elementos químicos e/ou substâncias, a Física se relaciona com as propriedades físicas dos materiais que são aquelas que ocorrem sem as transformações que ocorrem nas reações químicas.

A Mecânica está relacionada com as propriedades mecânicas, que são propriedades físicas voltadas para as aplicações dos materiais na fabricação de produtos, instalações e dispositivos para uso pela sociedade.

Os ensaios permitem determinar se um material atende ou não às especificações das normas técnicas para o emprego em alguma aplicação. Logo, esses ensaios estão muito relacionados às normas $\mathrm{e}$ devem segui-las.

Existem caso de divergência entre quem vende um material ou peça e quem os adquire. Nestes casos, procura-se fazer o ensaio num instituto independente e por meio dos laudos dos resultados define-se qual a parte incorreta ou que arcará com as despesas em relação à disputa gerada pelo material fabricado, adquirido e utilizado em alguma aplicação.

As disputas deste tipo podem envolver fóruns, pedidos de indenização, nomeação de uma representação (advogado), nomeação de assistente técnico (engenheiro, tecnólogo ou técnico) pela parte acusadora, nomeação de assistente técnico pelo réu (ou parte acusada) e nomeação de perito técnico (pela autoridade competente para atuar no processo, seja ele um Juiz, um Delegado, um Promotor Público etc.).

\section{TIPOS DE ENSAIOS}

Os ensaios são realizados em Corpos de Prova (CPs) que são normatizados conforme as normas da Associação Brasileira de Normas Técnicas - ABNT.

Os principais tipos de ensaios são: os de tração (em que se tenta "esticar" CP), compressão (em que se tenta "comprimir" o (P), ensaio de dureza (que é aquela na qual se verifica a dureza superficial pela tentativa de penetração de ferramenta, por exemplo, diamantada no caso do ensaio de 
dureza Vickers. Há também outros tipos de dureza, como é o caso da dureza Rockwell, na qual se tenta penetrar a superfície do CP por meio de uma esfera de aço). Há ainda o ensaio de fadiga (que é aquele no qual se verifica a resistência a esforços cíclicos), ensaios de Charpy (em que se verifica a resistência do CP a impactos).

Outra classificação dos ensaios pode ser pelo fato de serem destrutivos ou não destrutivos. Os primeiros são aqueles nos quais a peça ensaiada é destruída e não poderá mais ser utilizada (fabricam-se os corpos de prova a partir do material ou peça inutilizando-a). Entre os exemplos de ensaio destrutivo podemos destacar: ensaios de tração, compressão, fadiga e charpy.

No caso dos ensaios não destrutivos, temos os ensaios de raio- $X$, líquidos penetrantes e magnaflux.

\section{ENSAIO DE TRAÇÃO}

Este ensaio normalmente gera uma curva entre os parâmetros tensão e deformação. Nele procura-se obter a forma da curva, os valores dos limites de escoamento e limite de resistência do CP. Os corpos de prova são definidos em normas como é o caso da norma MB-4 da ABNT que define formatos e dimensões para cada tipo de teste. Algumas normas recomendadas para esse ensaio são apresentadas a seguir:

_ NBR 10130 - Chapas de aço - determinação da redução percentual da área pelo na direção da espessura;

_ NBR 6207 - Arame de aço;
_ NBR 6673 - Produtos planos de aço determinação de propriedades mecânicas;

_ NBR ISO 6892 - Materiais metálicos ensaio de tração à temperatura ambiente;

_ NM 264-2 - Chapas e tiras de aço carbono, aço ligado e aço inoxidável ferrítico de baixo carbono - método para determinar o coeficiente de encruamento mediante ensaios de tração axial;

_ NM-ISO783 1996 - Materiais metálicos Ensaio de tração a temperatura elevada.

Vale salientar que os ensaios mecânicos, normalmente, têm que atender as normas ABNT NBR e por este motivo não tem sentido realizar os ensaios sem segui-las.

\section{ENSAIO DE DUREZA}

Existem vários tipos de dureza utilizados no mercado. As mais comuns são a dureza Vickers, a Rockwell, a Brinell e a Shore.

Normalmente, os ensaios de dureza são realizados mediante a resistência do material à penetração de uma ferramenta. No caso da dureza Vickers é a resistência à penetração no corpo de prova do aço em teste, a uma ponta diamantada que pode ser o formato de um losango: mede-se a marca realizada num determinado aumento e para uma determinada carga de peso para penetração, por exemplo um kilo, ou meio kilo. Para o ensaio de dureza Rockwell e Brinell mede-se o diâmetro da marca realizada por uma ponteira de aço de alta resistência, com formato de bola e para uma carga pré-determinada. Para o 
ensaio de dureza Shore usa-se uma forma diferente de medição. Esta é indicada para ensaio no caso de peças grandes e mede-se o quanto uma bola lançada de certa altura, bate na peça e retorna (SOUZA, 1982).

Os valores de um ensaio podem ser convertidos em valores de outro por meio de tabelas de conversão.

Existem outros ensaios que são os de compressão, fadiga (para peças que sofrem esforços cíclicos), torção, dobramento e flexão. Todos ensaios seguem normas específicas da ABNT.

\section{DICAS PARA OS} ENGENHEIROS, TECNÓLOGOS, TÉCNICOS E PESSOAL DE OPERAÇÃO

Existem muitos outros ensaios, como é o caso dos ensaios de dobramento, resistência à corrosão etc.

O engenheiro, tecnólogo, técnico ou interessado deve procurar pelas normas que sejam aplicáveis e aceitas pelas partes envolvidas: vendedores, compradores, fornecedores, assistência técnica, usuários etc.

Os ensaios ou testes realizados em materiais de aço devem obedecer normas sejam da ABNT ou internacionais, como é o caso das normas americanas da ANSI (American National Standard Institution) ou da AISI (American Iron and Steel Institute) ou ASTM (American Society for Testing Materials), ou normas ISO que são europeias.

\section{BIBLIOGRAFIA CONSULTADA}

[1]. SOUZA, Sérgio A. Ensaios mecânicos de materiais metálicos. 5. Ed. São Paulo: Ed. Edgard Blucher, 1982. 


\section{EXERCÍCIOS}

1. Quais valores podem ser típicos para ensaio de dureza Rockwell C, de um aço SAE 1045 nos estados inicial, temperado e revenido?

2. Para que serve o ensaio de fadiga?

3. No ensaio de tração, o que é o limite de escoamento?

4. O que significa limite de resistência de um aço ensaiado a tração?

5. O que é região plástica e o que é região elástica de um aço ensaiado à tração?

6. Qual a importância das normas na realização dos ensaios mecânicos?

7. Quais normas americanas podem ser utilizadas nos ensaios mecânicos?

8. Para que serve a norma brasileira NBR $6207 ?$

9. Qual a diferença entre a forma de realização da dureza Shore e as outras?

10. Como são resolvidas as disputas judiciais em relação a um aço que foi adquirido como se fosse de uma determinada especificação e qualidade e na realidade não seguia a especificação mencionada? 


\section{LOGÍSTICA EM SIDERURGIA}

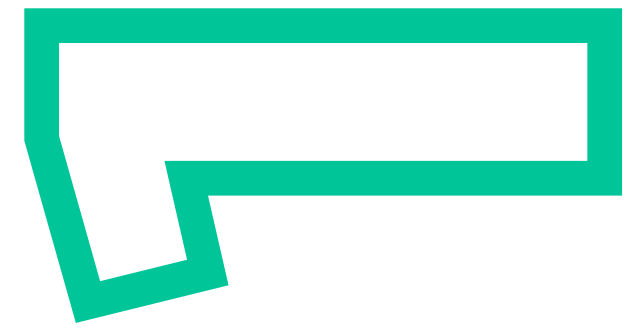

\section{Fala sobre:}

_ Introdução

_ Logística versus minério de ferro

_ Logística em relação aos mercados

_ Mercado consumidor

_ Logística e os modais

_ Dicas sobre logística

_ Referências Bibliográficas

_ Exercícios resolvidos 


\section{INTRODUÇÃO}

A logística em siderurgia e em qualquer área está relacionada às questões de organização interna dos layouts ou arranjos físicos dos equipamentos nas empresas, da movimentação de materiais e pessoas, da expedição de mercadorias, dos despachos de produtos, do armazenamento inicial, intermediário e final dos materiais, da conservação ou preservação, da localização dos materiais durante o processo de transporte etc.

Logística em relação ao minério de ferro

Um exemplo relacionado à venda de minério de ferro para a China: O Brasil é um grande produtor e conta com correntes da Austrália. Este país é um grande produtor de minério de ferro e possui a vantagem de estar próximo do grande país consumidor do minério para uso em seus processos de fabricação de aço.

A maior vantagem comparativa da Austrália reside na sua localização geográfica, mais próxima à China, ao Japão e aos países do sudeste asiático, onde realmente deve continuar a ocorrer o maior desenvolvimento da indústria siderúrgica mundial, pois o peso do custo de transporte para o minério de ferro representa cerca de 30\%, em média. A localização do Brasil privilegia as exportações para os Estados Unidos e a Europa (BNDES, 2007).

Como o Brasil está muito distante dos países asiáticos que são grandes consumidores de minério de ferro, uma solução logística foi a de trabalhar com navios muito grandes para diminuir os custos de transporte por tonelada de minério.

Outra solução logística foi a de montar um entreposto intermediário num país árabe, onde pode fazer grandes estoques de minério e tornar a posição mais próxima da China, de modo a gastar menos tempo no transporte até aquele país. Por meio dessas soluções, procurou-se aumentar a competitividade e sem elas não seria viável a venda de grandes quantidades de minério para os grandes mercados asiáticos.

\section{LOGÍSTICA DAS SIDERÚRGICAS EM RELAÇÃO AOS MERCADOS CONSUMIDORES}

A questão logística também está presente nas siderúrgicas que ora estão em regiões de fácil acesso ao minério ou em regiões próximas aos mercados consumidores de seus produtos de aço. Devido à grande quantidade de movimentação de material e o peso elevado que é exigida por esses produtos, torna-se importante ter malhas viárias para o transporte por meio de caminhões, linhas férreas com suas locomotivas e vagões e locais de armazenamento intermediário.

As siderúrgicas normalmente não fazem vendas para pequenos clientes. Elas atendem somente grandes clientes que compram grandes quantidades de materiais e por meio de contratos de longa duração. Um exemplo disso é aquele das indústrias automobilísticas que para fabricarem as carcaças ou carroceria dos seus 
veículos, precisam continuadamente de matérias-primas de aço compradas das siderúrgicas e que são processadas transformando-se em componentes veiculares. Estes serão montados formando produtos que são comercializados no mercado. Por conseguinte, quando as montadoras de veículos não vendem, ou diminuem suas vendas, também diminuem suas aquisições de peças e, por conseguinte, criam dificuldades em toda cadeia produtiva.

Outro exemplo está nas indústrias fabricantes de eletrodomésticos e geladeiras. Elas utilizam chapas de aço finas e precisam de grandes quantidades para fabricar os milhares de fogões, geladeiras e outros equipamentos. Normalmente, as indústrias que vão fabricar equipamentos ou produtos para o mercado estão sujeitas à sazonalidade do mercado: existem épocas em que as compras aumentam como é o caso do dia das mães e também das proximidades do Natal e existem épocas de baixas vendas como é o caso do período que vem após o Carnaval.

Como as indústrias trabalham no sentido de atender as lojas, grandes magazines e grande supermercados e shoppings, a indústria siderúrgica tem que acompanhar a necessidade das indústrias mencionadas e tem que fornecer seus materiais, como é o caso de bobinas, arames, chapas, fio-máquina etc em quantidade, qualidade, prazo e condições diversas no período desejado pelos clientes, que são indústrias voltadas para o atendimento a outros clientes. Neste sentido, é preciso que haja um planejamento por parte das siderúrgicas para a movimentação de matérias-primas para a fabricação de aços (minérios, calcário, carvão, fabricação de oxigênio etc) e também a previsão e alocação dos meios de transporte com antecedência para atender os clientes fabricantes de eletrodomésticos ou de veículos no prazo que eles precisam.

Caso as siderúrgicas não consigam atender seus clientes ocorre uma possibilidade deles adquirirem suas matérias-primas no exterior, importando os aços que necessitam. Para que os fabricantes nacionais tenham seu espaço e ganhos, é preciso que trabalhem bem a questão da logística para atender seus clientes em termos de prazos, preço, qualidade, quantidade e condições diversas.

\section{EXEMPLO DE CONSUMO DE GRANDE QUANTIDADE DE MATERIAL SIDERÚRGICO COM FINALIDADES ESPECIAIS}

Entre os exemplos de consumo elevado de produtos siderúrgicos fora das condições de mercado mencionadas no item anterior, encontram-se no caso de grandes projetos, como ocorre quando se constroem por exemplo, grande tubulações para transporte de gás, que podem atravessar milhares de quilômetros e exigem que se fabriquem e instalem grandes quantidade de tubos durante longos períodos.

Outro consumo especial pode ocorrer 
quando um país constrói vias férreas ligando regiões distantes, como é o caso de ferrovias lingando o norte ao sul ou leste a oeste de um país. Os milhares de quilômetros de linhas férreas vão exigir grandes quantidades de trilhos que podem comprometer a produção de muitas usinas siderúrgicas durante anos.

Após o término da produção para atender ao projeto, há também a fabricação para manutenção pois os trilhos vão ter uma certa vida útil e periodicamente precisam ser substituídos num processo normal de substituição. A movimentação da grande quantidade de materiais exige formulações logísticas que visem alcançar um menor custo, um tempo adequado e a entrega do produto dos trilhos nas condições necessárias pelos clientes para que não sejam obrigados a adquirir seus materiais no exterior.

\section{EXEMPLO DE ATENDIMENTO A CLIENTES MENORES}

Como já se mencionou anteriormente, para clientes pequenos que adquirem poucas toneladas de aço, ou mesmo alguns quilos, as grandes siderúrgicas integradas raramente atendem esses tipos de clientes.

O atendimento é realizado de forma indireta por meio de empresas distribuidoras de produtos siderúrgicos. Tais empresas localizam-se próximo aos grandes centros consumidores ou em regiões onde há grande concentração industrial. Os distribuidores de aço adquirem grandes quantidades das siderúrgicas, estocam em seus pátios, fazem a movimentação, corte em quantidades menores e comercialização para pequenas lojas ou indústrias que, desta forma, podem ser melhor atendidos em suas necessidades. Essas empresas, que atuam localmente, têm condições de conhecer melhor seus clientes e atendê-los de modo mais adequado em termos logísticos, devido à proximidade com seus consumidores.

\section{LOGÍSTICA E OS MODAIS}

A questão dos modais está ligada à definição da forma como os produtos siderúrgicos serão entregues aos clientes. Normalmente, nas siderúrgicas, existem departamentos que cuidarão dos despachos de produtos, da definição dos locais de armazenamento intermediário, dos meios de transporte, seus custos, quantidades e planejamento da entrega ao cliente, alocando recursos e procurando atender prazos e custos condições diversas. O planejamento da entrega dos produtos ao cliente em quantidades, prazos e condições de entrega exige o conhecimento dos meios de transporte e muita negociação.

Quando há condições adversas, como é o caso de greves ou acidentes, é preciso verificar se existem alternativas para o atendimento aos clientes e bem como na questão dos custos, quem arcará com os custos extras e se isso será viável para as partes.

Os contratos de fornecimento dos materiais para os clientes das siderúrgicas normalmente preveem multas para 
atrasos e não cumprimento das condições contratuais pois os clientes delas também têm outros contratos com outros clientes, como é o caso da indústria de eletrodomésticos que já vendeu sua produção para as grandes redes e a não entrega no prazo pode significar a perda de vendas e, por conseguinte, o prejuízo que quando ocorre normalmente será acompanhado de multas contratuais, levando a condições complexas em que várias partes estarão perdendo valores. O trabalho da seleção dos modais sempre há contratos com seguros para que se garanta as entregas. Entre os modais, os mais utilizados são os meios ferroviários associados à armazenagem intermediária em depósitos para evitar que os materiais siderúrgicos fiquem expostos ao tempo e a seguir a entrega aos clientes industriais por meio de caminhões. Outras rotas entre as siderúrgicas e os clientes industriais incluem o transporte ferroviário, saindo da siderúrgica até o porto para realizar a cabotagem que é o transporte marítimo nacional.

Quando o material chega ao porto, é carregado nos navios. Estes vão a outros portos próximos dos destinos e lá vão ser armazenados e posteriormente transportados por meio de caminhões para os clientes industriais.

É interessante considerar que nos transportes nos modais é preciso utilizar amarrações nas cargas para que elas não se desloquem e se danifiquem. Para cargas menores utilizam-se pallets de madeira e cestas metálicas que podem ser colocadas no interior de contêineres. As cunhas de madeira são bastante empregadas para fixar os produtos siderúrgicos, evitando seu deslocamento. No transporte com uso de empilhadeiras, normalmente pode-se verificar a viabilidade do emborrachamento dos garfos desses meios de movimentação de materiais para evitar que risquem os produtos. Um exemplo da importância deste procedimento está no seguinte fato: se uma bobina de chapa fina de aço for riscada, quando ela for cortada e utilizada na fabricação de um eletrodoméstico, pode ocorrer que o risco gerado na movimentação persista no produto final e raramente um cliente vai querer adquirir uma geladeira, fogão, enceradeira ou outro eletrodoméstico que esteja riscado.

Outro aspecto está relacionado ao transporte de material das siderúrgicas que ocorra no tempo: quando chapas, bobinas, ou cantoneiras são armazenadas em locais com humidade ou chuva, podem desenvolver ferrugem e estas podem persistir nos produtos. Uma das formas de se minimizar os problemas mencionados está na decapagem que ocorre nas siderúrgicas. Tal decapagem consistem em mergulhar os produtos siderúrgicos em tanques com soluções alcalinas eu vão atacar as superfícies dos produtos siderúrgicos, deixando-os com aspecto de novo e brilhante por retirar a fina camada de óxidos.

Após a decapagem, os produtos carregados nos modais podem ser cobertos com plástico para evitar o contato com a humidade do tempo e da chuva. Há casos em que as condições de entrega exigem que o produto esteja livre de ferrugem e, neste caso, faz-se a aplicação de 
produtos químicos que vão evitar a ocorrência daquela e, neste caso, os produtos aumentam os custos e são negociados com os clientes de modo a fazer parte das condições de entrega.

\section{DICAS PARA OS ENGENHEIROS, TECNÓLOGOS, TÉCNICOS E PESSOAL DE OPERAÇÃO}

É importante que engenheiros, tecnólogos, técnicos e profissionais em geral envolvidos com as indústrias siderúrgicas e as indústrias de grande porte em geral tenham uma noção sistêmica que é a visão do todo, suas partes e o relacionamento entre elas. O conhecimento da forma de trabalho dos diversos setores e áreas bem como as dificuldades e possibilidades de cada área pode ajudar na formação de equipes que vão trabalhar de modo mais sincronizado. Não basta apenas realizar um trabalho sem saber o que vem antes e o que virá após. É preciso, dentro de um contexto profissional, entender o que está em jogo nas diversas áreas e, desta forma, pode-se trabalhar cooperativamente e colaborativamente para que todos consigam manter seus empregos, trabalhar bem e alcançar o sucesso de todos. Em termos de documentação, os profissionais desta área têm que trabalhar internamente nas empresas, com ordens de serviço, e externamente com notas fiscais que são emitidas para saída de produtos da siderúrgica e com conhecimentos de carga que são relações de produtos, quantidades e riscos.

\section{REFERÊNCIAS}

[1]. BNDES. Minério de ferro. Publicado em 2007. Disponível em: <http://www. bndes.gov.br/SiteBNDES/export/sites/ default/bndes_pt/Galerias/Arquivos/ conhecimento/setorial/ferro.pdf>. Acesso em: 11 jul. 2016. 


\section{EXERCÍCIOS}

1. A logística trabalha com:

( ) A. Parte financeira, obtenção de recursos e empréstimos para aquisição de materiais e matérias-primas.

( ) B. Movimentação de matérias-primas, materiais e produtos, armazenagem interna nas empresas e externamente com a definição das rotas e dos modais.

( ) C. Seleção de pessoal, treinamento e definição de cargos e salários de pessoal que trabalha numa organização.

( ) D. Aquisição de matérias-primas, cotação, definição de fornecedores e trabalho com alinhamento de metas em relação a fornecedores.

( ) E. Comercialização, definição de contratos de vendas, atendimento inicial aos clientes para verificar necessidades de materiais, condições de pagamento e negociações.

2. Em termos de documentação, quais documentos são utilizados na movimentação e armazenagem interna e quais são necessários para saída de produtos da siderúrgica?

3. Assinale a alternativa que não corresponde a um meio de transporte e movimentação de material no interior de uma siderúrgica.

( ) A. Vagões ferroviários
( ) B. Pontes rolantes

( ) C. Pórticos

( ) D. Empilhadeiras

( ) E. Canoas

4. Assinale a alternativa que não corresponde a um modal utilizado para transporte externo de produtos de uma siderúrgica.

( ) A. Vagão ferroviário.

( ) B. Caminhões.

( ) C. Navios de cabotagem.

( ) D. Planadores.

( ) E. Navios de longa transoceânicos.

5. No transporte de bobinas de chapa fina para fabricação de fogões e geladeiras ou para o transporte de bobinas de fio máquina de aço, que cuidados podem ser tomados em relação às empilhadeiras e por que?

6. No armazenamento de produtos de uma siderúrgica, pode ocorrer a oxidação de modo a se ter um aspecto superficial ruim para os produtos. O que se costuma fazer para que se entregue um produto com aparência superficial boa e de material novo, para os clientes?

7. Quais as finalidades do uso de pallets, cunhas de madeira e amarrações de produtos siderúrgicos nos modais?

8. O que é a cabotagem para transporte 
Tecnología siderúrgica

de material siderúrgico?

9. Responda à pergunta: As grandes siderúrgicas integradas nacionais atendem normalmente os pequenos clientes que compram somente alguns quilos de aço?

10. Qual setor ou departamento numa siderúrgica integrada faz a definição de rotas de dos modais para entrega de produtos aos clientes? 


\section{SAUDE, SEGURANÇA E HIGIENE NA SIDERURGIA}

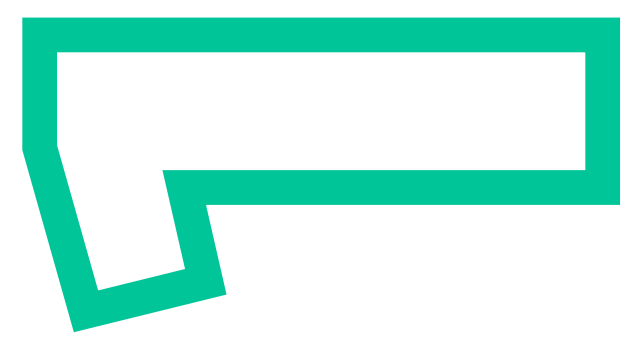

\section{Fala sobre:}

_ Introdução

_ Riscos e contramedida

_ Dicas sobre segurança

_ Referências Bibliográficas

_ Exercícios resolvidos 


\section{INTRODUÇÃO}

As indústrias processam matérias-primas e produzem produtos que são importantes para a sociedade. Para realizar seus trabalhos necessitam de instalações, equipamentos, matérias-primas, pessoal, transporte, treinamento e vários itens formando a complexidade do trabalho com muitas variáveis.

A questão da saúde, segurança e higiene é importante para as organizações e crítica naquelas que possuem condições que podem oferecer riscos à saúde e à vida humana. Os riscos industriais são controláveis de modo a alcançar a sustentabilidade nos meios industriais.

A siderurgia, em particular, é uma área de trabalho na qual há diversos tipos de riscos que incluem várias etapas processuais em que há calor, altas temperaturas riscos à visão, altas pressões, mecânica pesada, ruídos elevados, gases, riscos de explosões, perigos de ferimentos por corte em sucatas etc.

Nas linhas seguintes elencam-se alguns dos principais riscos em processos industriais da siderurgia e as principais contramedidas.

\section{RISCOS E CONTRA- MEDIDAS}

A tabela $\mathrm{XI}$, a seguir, apresenta os principais riscos e contramedidas em postos de trabalho da siderurgia.

Processo

1) Estocagem em baias
de carvão, minério de
ferro, calcário, fluorita,
dolomita, ferros liga e
outros. 2) Retirada de
materiais para uso em
processo.

Pátio de Matérias-primas

\section{Riscos}

Acidentes na movimentação de toneladas de materiais

\section{Contramedida}

Trabalhar com normas de segurança. Definir locais seguros para as pessoas caminharem. Utilizar Equipamentos de Proteção Individual (EPI). Sinalizar as áreas informando os riscos. Utilizar travas na botoeira de controle para que os operadores tenham a certeza de só acionar os equipamentos em caso de área segura.

Trabalhar com normas de segurança. Definir locais seguros para as pessoas caminharem, e locais para os vagões e locomotivas, caminhões e empilhadeiras, tratores e guindastres funcionarem. Utilizar sinalização de alerta de aproximação de veículo 
Tecnología siderúrgica

\section{Local Processo Riscos Contramedida}

Pátio de Matérias-primas
Patio de Carvão

Risco de incêndio

Alta temperatura do forno de coqueificação.

Coqueificação

Coqueria
Grandes quantidades e pesos de materiais movimentados
Trabalhar com normas de segurança. Molhar carvão segundo normas para evitar aumento de temperatura. Utilizar EPIs.

Trabalhar com normas de segurança. Definir locais seguros para as pessoas caminharem. Utilizar Equipamentos de Proteção Individual (EPI). Sinalizar as áreas informando os riscos. Utilizar travas na botoeira de controle para que os operadores tenham a certeza de só acionar os equipamentos em caso de área segura.

Trabalhar com normas de segurança rígida.

Gases dos processos

Tratamento dos gases devem ser inalados e também há riscos de industriais que não explosão.

Utilizar EPIs. Permitir a passagem de pessoas somente em locais pré-determinados que sejam seguros. Usar EPIs adequados.

Trabalhar com normas de segurança rígida.

Trabalhar com normas de segurança rígida. Definir locais seguros e procedimentos de trabalho seguro. Usar EPIs adequados.

Trabalhar com normas de segurança rígida.

Evitar umidade e acúmulo de poças de água em regiões onde não se permite este problema. Realizar inspeções rotineiras e

Riscos de explosão manutenção preditiva, preventiva e corretiva para evitar o funcionamento de equipamentos fora das especificações. Definir locais seguros e procedimentos de trabalho seguro. Usar EPIs adequados. 


\section{Local Processo Riscos Contramedida}

Trabalhar com normas de segurança rígida.

Trabalho com toneladas de material de carga

Definir locais seguros e procedimentos de trabalho seguro. Usar EPIs adequados.

Todas regiões do forno

Alto forno
Riscos de queda (Muitos altos-fornos têm mais de cem metros de altura e pessoas trabalhando em vários níveis
Trabalhar com normas de segurança rígida. Definir locais seguros e procedimentos de trabalho seguro. Usar EPIs adequados.

Trabalhar de acordo com as normas da área.

Realizar os procedi-

Verificar se não há avermelhamento ou Carcaça aumento anormal de temperatura mentos de segurança de diminuição da carga, aumento da velocidade de refrigeração pela camisa de água, realizar reparo dos refratários. Utilizar EPIs.

Permitir o transito somente em áreas permitidas e usar EPI.

Estação de Dessulfuração

Local do sopro

Alta temperatura

Usar EPI e ficar em áreas protegidas

Usar EPI, inspecionar a sucata e se necessário fazer secagem com maçarico.

Usar EPI, ficar em local protegido na hora do carregamento da gusa no LD. Respeitar todos procedimentos de segurança da área do LD.

Aciaria

Respingos

Usar EPI, e ficar somente nas áreas permitidas e com proteção.

Sopro de oxigênio

Trabalhar seguindo os procedimentos de segu-

Avermelhamento local da carcaça do forno LD rança para o momento do sopro no LD.

Seguir todos procediVazamento de aço

Cuidados com os respingos mentos de segurança para o vazamento. 
Tecnología siderúrgica

\begin{tabular}{|c|c|c|c|}
\hline Local & Processo & Riscos & Contramedida \\
\hline $\begin{array}{l}\text { Estação de desgaseifi- } \\
\text { cação }\end{array}$ & Alta temperatura & $\begin{array}{c}\text { Cuidados com a área de } \\
\text { desgaseificação }\end{array}$ & $\begin{array}{l}\text { Seguir todos procedi- } \\
\text { mentos de segurança da } \\
\text { área de desgaseificação. }\end{array}$ \\
\hline \multirow{4}{*}{ Aciaria Elétrica } & \multirow{2}{*}{ Cuidados com a carga } & Material pesado & $\begin{array}{l}\text { Nunca ficar abaixo das } \\
\text { cargas que estão sendo } \\
\text { transportadas pelo meio } \\
\text { das pontes rolantes }\end{array}$ \\
\hline & & $\begin{array}{l}\text { Manipulação de } \\
\text { oxigênio e altas tempe- } \\
\text { raturas no forno }\end{array}$ & $\begin{array}{c}\text { Seguir todos procedi- } \\
\text { mentos de segurança da } \\
\text { área. }\end{array}$ \\
\hline & $\begin{array}{l}\text { Cuidados com a alta } \\
\text { potência elétrica }\end{array}$ & $\begin{array}{c}\text { Evitar riscos com alta } \\
\text { energia }\end{array}$ & $\begin{array}{c}\text { Ficar somente nos locais } \\
\text { permitidos e cumprir } \\
\text { todos requisitos de } \\
\text { segurança da área. }\end{array}$ \\
\hline & $\begin{array}{l}\text { Ruídos dos eletrodos } \\
\text { durante a operação }\end{array}$ & $\begin{array}{l}\text { Possibilidade de desen- } \\
\text { volver surdez }\end{array}$ & $\begin{array}{l}\text { Utilizar EPIs. Fazer } \\
\text { exames de saúde } \\
\text { regular. Seguir todos } \\
\text { procedimentos de segu- } \\
\text { rança da área. }\end{array}$ \\
\hline \multirow[t]{2}{*}{$\begin{array}{l}\text { Lingotamento conven- } \\
\text { cional (Lingoteiras) }\end{array}$} & $\begin{array}{l}\text { Evitar umidade na } \\
\text { lingoteira }\end{array}$ & $\begin{array}{l}\text { Possibilidade de explo- } \\
\text { sões. }\end{array}$ & $\begin{array}{c}\text { Evitar umidade. Aquecer } \\
\text { com maçarico se neces- } \\
\text { sário. Usar EPI e seguir } \\
\text { os procedimentos da } \\
\text { área de trabalho em } \\
\text { questão. }\end{array}$ \\
\hline & $\begin{array}{l}\text { Na hora do lingota- } \\
\text { mento }\end{array}$ & $\begin{array}{c}\text { Cuidados com alta } \\
\text { temperatura e emer- } \\
\text { gências }\end{array}$ & $\begin{array}{c}\text { Usar EPIs. Seguir as } \\
\text { instruções da área de } \\
\text { trabalho. }\end{array}$ \\
\hline \multirow[t]{2}{*}{ Lingotamento Contínuo } & $\begin{array}{c}\text { Cuidados no carrega- } \\
\text { mento da panela de } \\
\text { gusa }\end{array}$ & $\begin{array}{l}\text { Verificar se a panela } \\
\text { está encaixada correta- } \\
\text { mente e se as válvulas } \\
\text { gaveta tanto da panela } \\
\text { quanto do distribuidor } \\
\text { estão funcionando. }\end{array}$ & $\begin{array}{c}\text { Caso haja dificuldades, } \\
\text { deve-se seguir os proce- } \\
\text { dimentos de segurança } \\
\text { da instalação. Por } \\
\text { exemplo jatear oxigênio } \\
\text { no bocal de vazamento } \\
\text { que esteja entupido, ou } \\
\text { desviar a panela para } \\
\text { lingotamento conven- } \\
\text { cional de emergência. } \\
\text { Seguir os procedi- } \\
\text { mentos de segurança da } \\
\text { área em consideração. }\end{array}$ \\
\hline & Cuidados no vazamento & $\begin{array}{l}\text { Estouro de veio de aço } \\
\text { na câmara de resfria- } \\
\text { mento ou vazamento } \\
\text { de água no molde de } \\
\text { cobre. }\end{array}$ & $\begin{array}{l}\text { Adotar os procedi- } \\
\text { mentos de segurança da } \\
\text { área em questão. }\end{array}$ \\
\hline
\end{tabular}




\section{Local Processo Riscos Contramedida}

Cuidado com os maçaricos de corte oxiacetilênicos, cuidados com as temperaturas

Altas temperaturas de aquecimento das placa e chapas. Seguir Laminação Cuidados operacionais os procedimentos de segurança da área em consideração.

Seguir os procedimentos de segurança da área em consideração.

Seguir os procedimentos de segurança da área em consideração.

\section{Cuidados com a movi- mentação}

Movimentação e

Pátio de placas estoque de materiais
Cuidados com material quente em resfriamento e com material pesado

Definir caminhos seguros para as pessoas andarem. Evitar ficar sob cargas em movimento que estão sendo

transportadas por pontes rolantes pois em caso de queda de tais materiais podem ocorrer acidentes sérios.

Seguir os procedimentos de segurança da área em consideração.

Definir locais seguros para as pessoas transitarem. Seguir os procedimentos de segurança da área em conside-
Pátio de produtos side- Movimentação e rúrgicos estoque de materiais
Cuidado com a movi- mentação de material pesado

$$
\text { ração. }
$$

Definir locais seguros para as pessoas transitarem. Seguir os procedimentos de segurança da área em conside-
Cuidado com a movi- mentação de material pesado

$$
\text { ração. }
$$

Seguir os procedimentos de segurança da área em consideração.

Seguir os procedimentos de segurança da área em consideração.
Utilidades: geração de vapor e tratamento de água.
Cuidados com as condições locais de trabalho
Verificar regularmente os equipamentos. Trabalhar em níveis seguros. 
DICAS PARA OS ENGENHEIROS, TECNÓLOGOS, TÉCNICOS E PESSOAL DE OPERAÇÃO

_ É preciso trabalhar sempre com segurança, nossa e dos colegas, para se ter sustentabilidade;

_ O zelo pela segurança passa pela definição conjunta de normas para as áreas de trabalho e o uso e obediência a elas;

_ Torna-se importante que hajam reuniões frequentes para se discutir os problemas e formas de agir ou necessidades para que se minimizem as dificuldades e se melhore também a qualidade e produtividade de modo seguro. 


\section{EXERCÍCIOS}

1. No pátio de matérias-primas, nos locais onde se armazena carvão, que riscos podem ocorrer com esse tipo de material?

2. Que riscos podem existir na coqueria quando se faz o tratamento dos gases?

3. Como se pode evitar os riscos de explosão no AF?

4. O que pode indicar um avermelhamento em alguma região da carcaça do AF?

5. Numa fábrica de oxigênio, o que produzirá oxigênio para ser utilizado na aciaria, qual o maior risco existe?

6. No lingotamento contínuo, que riscos e cuidados principais se tem que tem relação as panelas de aço?

7. Cite um cuidado importante no trabalho no lingotamento convencional.

8. A aciaria elétrica por meio de fornos com eletrodos pode causar um tipo de problema funcional decorrente do trabalho durante anos nesta área. Qual é o principal problema ligado aos fornos elétricos devido aos ruidos?

9. Na expedição de materiais siderúrgicos, quais são os maiores riscos que podem ocorrer? Cite pelo menos um.

10. As siderúrgicas integradas geralmente têm instalações para fabricação de oxigênio que é utilizado na aciaria LD para sopro de oxigênio no convertedor. $\mathrm{Na}$ Fábrica de Oxigênio, qual é o maior risco? 


\section{GLOSSÁRIO}


A bobada - é o teto curvilíneo de fornos metalúrgicos como é o caso dos fornos elétricos.

Ácido - composto capaz de transferir Íons $(\mathrm{H}+)$ numa reação química.

Aço - liga de ferro carbono com baixo teor de carbono, abaixo de $2 \%$.

Aço inoxidável - regularmente conhecido como inox, ele é uma liga ferro-carbono-cromo e níquel. Esta liga normalmente é mais resistente à corrosão aquosa que os aços comuns ao carbono. A resistência à corrosão ocorre devido à formação de uma película de oxido de cromo na superfície do material e essa impede a ocorrência da oxidação, tornando o material inoxidável.

Alívio de tensões - é um tratamento térmico em aços que ocorre à temperaturas da ordem de 150 a $250^{\circ}$ centígrados durante algumas horas com a finalidade de diminuir as forças internas resultantes de outros processos e que poderiam tornar o material quebradiço.

Alto-forno - forno para fabricação de ferro gusa a partir de minério de ferro, carvão e fundentes. Eles são utilizados nas usinas siderúrgicas integradas.

Análise gravimétrica - consiste em determinar a quantidade de um elemento, radical ou composto presente em uma amostra, eliminando todas as substâncias que interferem e convertendo o constituinte ou componente desejado em um composto de composição definida, que seja suscetível de se pesar.
Análise química - é o conjunto de técnicas de laboratório utilizadas na identificação das espécies químicas envolvidas em uma reação, como também a quantidade dessas espécies

Análise química analítica quantitativa - é o estudo de métodos para separação e determinação da quantia de um componente em uma mistura ou solução.

Arame - é fio metálico, geralmente flexível ou haste metálica feita em vários comprimentos e diâmetros.

Argamassa refratária - é o material refratário utilizado para unir os tijolos refratários e/ou preencher os espaços vazios deixados no revestimento refratário.

Austempera - é um processo de tratamento térmico para metais ferrosos com quantidades médias a altas de carbono que produz uma estrutura metalúrgica chama bainita. É utilizado para aumentar a força e a tenacidade e para reduzir a distorção nos materiais ferrosos.

Barras - Seção quadrada, circular ou poligonal com dimensões menores que $100 \mathrm{~mm}$.

Bascular - é levantar ou erguer.

Basculamento - é o levantamento.

Bico da lança de oxigênio do convertedor - Este bico é construído seguindo o formato De Laval que permite a emissão de um jato supersônico.

Bíco de Bunsen -éum queimador gás 
que é utilizado em laboratórios químicos para aquecimento por chama.

Bico de vazamento do convertedor - é o local do convertedor LD por onde é realizado o vazamento de aço que deve ocorrer após o processo de sopro. Nele não se realiza o vazamento de escória líquida.

Blocos - Seção quadrada ou ligeiramente retangular, entre 150 e $300 \mathrm{~mm}$ de lado.

Bobina - Produto plano laminado com largura mínima de 500 mm enrolado na forma cilíndrica.

Bocal - é a abertura de recipiente. É um tipo de boca.

Britador - equipamento que é utilizado para cominuição ou diminuição do tamanho de minerais. Os mais conhecidos são os britadores de mandíbulas.

Briquet - é um aglomerado de minério e carvão, ou pode ser também um aglomerado composto de pó de carvão e um aglutinante (tipo argila, breu, glutaraldeído etc.) que pode ser usado como combustível.

Carbono - Elemento químico de número atômico 6 e número de massa 12. Além do carvão, possui vários alótropos como é o caso do diamante e de grafite. Pode ser obtido a partir de material de biomassa de florestas sendo denominado de "carvão vegetal" ou de origem mineral que é denominado "carvão mineral". Este é extraída por meio da mineração. Alguns carvões como é o caso do coque metalúrgico possuem propriedades de resistência mecânica.
Outros como é caso do carvão mineral brasileiro, contêm teores de enxofre que vão passar para o banho metálico.

Carvão vegetal - é matéria prima e muitos processos siderúrgicos. Esse material é produzido a partir da queima de madeiras provenientes de florestas.

Cementação - é um tipo de tratamento termoquímico que visa aumentar a quantidade de carbono na superfície do aço e com isso melhorar a temperabilidade nessa região. Pode ser feito por meio de atmosferas ricas em carbono ou em caixas contendo carvão.

Cerâmicos - um dos tipos de materiais que não são nem metais e nem polímeros. São formados por óxidos.

Chapa Grossa - Largura acima de 200 $\mathrm{mm}$, espessura maior que $5 \mathrm{~mm}$.

Comuni icação - é interação bidirecional de dados e informações.

Coque - tipo de carvão mineral de alta resistência e que é utilizado nos altos fornos por não se degradar mesmo à alta temperatura e desta forma, ele ajuda a suportar a carga que é realizada no AF.

Coqueria - estação que existe numa usina siderúrgica a carvão mineral e que é formada por uma bateria de fornos de aquecimento onde a finalidade é aquecer a uma temperatura tal que permita a liberação de gases do carvão coque, a diminuição do volume do carvão e compactação que o torna mais resistente para utilização no AF. 
Combustão - é a queima. Também é o consumo de gás, solido ou líquido por meio de uma chama.

\section{Conversor ou convertedor LD - é} um tipo de forno no qual se faz o sopro de oxigênio sobre o banho líquido de gusa com a finalidade de transformá-lo em aço líquido.

Correia transportadora - é um equipamento de movimentação ou transporte de material, que é usado para realizar o carregamento, abastecimento de materiais finos, úmidos ou abrasivos, em geral sobre pilhas ou amontoamento seguindo o angulo de acomodação do material.

Corrosão - desgaste gradual de um corpo qualquer que sofre transformação química e/ou física, proveniente de uma interação com o meio ambiente. É um processo contrário ao da redução dos metais.

Dessulfuração - é o processo de remoção de enxofre do banho líquido de gusa por meio da injeção de material (CaCO3, CaO etc) que vai formar escória que reterá boa parte do enxofre baixando seu conteúdo no banho líquido.

Diagrama ferro-carbono - e um tipo de diagrama onde no eixo vertical estão as temperaturas e no horizontal as porcentagens dos elementos constituintes. Eles podem ser binários quando consideram somente o material principal e um elemento de liga como é o caso do diagrama ferro-carbono ou podem ser ternários, por ex.: Fe-C-Cr, ou quaternários etc.
Difração de raios $X$ - é a mais indicada na determinação das fases cristalinas.

EDTA - ácido etilenodiaminotetracético, tem quatro grupos carboxila e dois grupos amina que podem atuar como doadores de pares de elétrons, ou bases de Lewis. É usado na análise por titulação complexométrica.

Elemento químico - um conjunto de átomos que têm o mesmo número de prótons em seu núcleo, ou seja, o mesmo número atômico (Z).

Empillhadeira - é uma máquina móvel utilizada na movimentação de materiais e que é própria para realizar o empilhamento e/ou a arrumação de certos produtos ou carga em armazéns, fábricas, portos etc.

Encruamento - é um fenômeno que ocorre nos aços deformados a frio, no qual a medida que se deforma o material, ele adquire propriedades de aumento de resistência e dureza.

Engenharia - é a capacidade de aplicar os conhecimentos científicos de forma prática a fim de projetar, produzir novas utilidades, e manter e otimizar o uso das já existentes.

Engenharia de materiais - modalidade da engenharia em que a interdisciplinaridade da física e química são utilizadas no estudo, na produção e transformação da materiais metálicos, cerâmicos, polímeros ou compostos.

Engenharia metalúrgíca - éa modalidade da engenharia de materiais que usa 
conhecimentos empregados na transformação de minérios em metais e ligas metálicas e em sua aplicação na indústria.

Engenharia de minas - modalidade da engenharia que se ocupa do aproveitamento dos recursos da Terra, por meio da exploração de minas, lavra, beneficiamento e movimentação e armazenamento de produtos minerais.

Engenharia de produção - modalidade da engenharia que se dedica a conceber, melhorar e implementar e simular e otimizar sistemas que envolvem pessoas, materiais, informações, equipamentos, energia e maiores conhecimentos e habilidades.

Engenharia química - modalidade da engenharia responsável por projetar, construir e operar plantas industriais relacionadas com transformações químicas.

EPI - equipamento de proteção individual que geralmente inclui capacete, óculos de proteção, protetor auricular, caneleiras de couro, aventais de couro, luvas de couro, óculos protetor contra luminosidade e outros que podem variar conforme os riscos da área de trabalho.

Eutético - é o material que apresenta o menor ponto de fusão para as ligas de um determinado sistema binário de metais.

Extrusão - é o processo pelo qual o aço é forçado por meio de compressão a ir ao encontro de uma matriz que contém um formato por exemplo de um perfil e adquire tal formato na saída.
Ferro - é um elemento químico de número atômico 26. Ele é metálico, sólido, abundantemente encontrado na natureza na forma de óxidos. Quando obtido por meio de processos siderúrgicos pode ter diversas aplicações industriais

Ferro fundido - é uma liga de ferro em mistura eutética com elementos à base de carbono e silício. Forma uma liga metálica de ferro, carbono (a partir de 2,11\%), silício (entre 1 e 3\%), podendo conter outros elementos químicos.

Fieira - peça utilizada na trefilaria para realizar a redução de espessura do fio máquina que vai ser transformado em arame de espessura menor.

Filtro - é um dispositivo separador que permite a passagem de algum material e retém outros.

Finos - material particulado de pequenas dimensões que é gerado durante o processamento de minérios.

Fio-máquína - normalmente de seção circular com o diâmetro menor que $12,7 \mathrm{~mm}$, produzido em rolos ou bobinas

Física - ciência que estuda a natureza e seus fenômenos nos aspectos mais gerais, procurando analisar e explicar as relações causa-efeito e as propriedades.

Forja - conjunto dos instrumentos de trabalho do ferreiro: fornalha, bigorna, fole, malho etc.

Forjar - dar forma por meio de martelmento. 
Forno - dispositivo utilizado para aquecimento dos metais ou outros materiais.

Forno de banho de sal - é um forno tipo poço, com revestimento refratário interno e com resistências elétricas que vão aquecer e fundir um sal que vai manter uma temperatura adequada para alguns tipos de tratamento térmico como é o caso da denominada martempera.

Forno de indução - é um forno elétrico silencioso que utiliza o eletromagnetismo para gerar correntes elétricas de indução no interior do metal que será trabalhado.

Forno elétrico a arco - é um tipo de forno de fusão de aço no qual se trabalha com eletrodos trifásicos ou bifásicos. Eles exigem a definição de um programa de potência e durante sua operação geram ruídos intensos e muito fortes que ao longo do tempo podem causar surdez nos operadores que trabalham próximo aos fornos.

Forno com queimador a gás - são fornos cujo aquecimento é realizado por meio de bicos queimadores de gás.

Forno com queimador a óleo - são fornos cujo aquecimento é realizado por meio de bicos queimadores de óleo.

Fresa - peça de engrenagem, us. para desbastar ou cortar metais, que consiste em cortador de diversos gumes girando em movimento contínuo.

Fundição - é a área fabril que possuir fornos de fusão de aço e/ou moldes onde o aço vai ser vertido para adquirir uma forma de produto.
Fulcro - base, ponto de apoio, sustentáculo.

Furadeira - é a ferramenta utilizada para perfurar madeira, metal, pedra, plástico, louça etc.

F usão - é o derretimento do metal ou liga metálica que ocorre numa determinada temperatura.

Gás - é um estado da matéria que tem a característica de se expandir espontaneamente, ocupando a totalidade do recipiente que a contém.

Gasômetro - é dispositivo ou instalação dispositivo próprio para recolher gases em formação.

Germânio - quím elemento químico de número atômico 32, símbolo Ge e que é semicondutor.

Informação - é o resultado do processamento de dados, é matéria prima para a tomada de decisão. É unidirecional.

Laminação - processo no qual o aço no estado sólido é passado entre rolos que diminuem a espessura do material ou então lhe fornecem um formato por exemplo de vergalhões ou perfilados.

Lança de oxigênio do convertedor - é um tubo de aço que contem outros tubos no seu interior por onde passa agua de refrigeração e o tubo mais central é destinado a passar o oxigênio que será soprado no banho de gusa para transformá-lo em aço. O bico desta lança é fabricado em cobre eletrolítico 100\% 
puro para que ocorra nele um bom resfriamento. Esse bico é soldado nos tubos de aço mencionados. A lança é testada a alta pressão e vazão e não pode ter vazamento, antes de sua liberação para uso em operação de sopro no convertedor.

Liga - novo material produzido a partir da união de um metal de base associado a pelo menos um ou a um segundo ou terceiro ou quarto ou quinto etc ou mais tipos de materiais componentes. A liga passa a ser um novo tipo de metal com propriedades diferenciadas.

Ligação metálica - é um tipo de ligação química que ocorre nos metais. Ela se caracteriza por compartilhar elétrons da última camada que formam uma espécie de nuvem eletrônica que é compartilhada no material.

Ligação química - é o processo de união entre átomos formando moléculas.

Maçaríco - é um dispositivo que envia gás por um tubo, e o despeja sobre uma chama produzida pela quima de um gás comburente, e que é usada para soldar ou fundir metais.

Magnetismo - propriedade física dos materiais (metálicos ou cerâmicos) que os torna ferrognéticos

Martêmpera - é um tipo de tratamento térmico no qual se realiza uma têmpera de aços normalmente em um banho de sal derretido a uma temperatura e que é interrompida logo acima da temperatura de início da martensita.
Material - é tudo aquilo que tem existência física e pode compor objetos.

Matéria-prima - material que é utilizado na entrada de um processo para ser trabalhado e resultar num produto.

Meĩo ambiente - é a condição local de um determinado sistema no qual se insere um estudo.

Metal - material que se caracteriza pela presença da ligação metálica, condução elétrica e de calor, possui o brilho metálico característico e possui poucos elétrons na última camada atômica.

Metalografia - é o estudo das propriedades e estrutura de metais e ligas com a aplicação do microscópio.

Mineral - é material não orgânico, que é natural e que é obtido por meio de extração na terra.

Minério - é mineral ou rocha existente em regiões da Terra, que podem ser processados por meios mecânicos, físicos e químicos para a extração de uma ou mais substâncias que sejam úteis para a sociedade.

Moinhos - são máquinas cuja finalidade é a moagem ou a comunuição em tamanhos menores que aquele fornecido pelos britadores. Os moinhos pode ser de bolas, de barras etc.

Nióbio - elemento químico de número atômico 41, cujo símbolo é Nb. Ele é empregado em aços e ligas metálicas. Funde-se a 2400 graus centígrados e é utilizado na 
fabricação de turbinas de aviões e motores de foguetes.

Nitretação - é um tratamento termoquímico realizado em fornos com atmosferas ricas em nitrogênio e cuja finalidade é enriquecer a superfície do aço em nitrogênio, formando nitretos que vão ajudar a fornecer a resistência mecânica na superfície.

Ondas eletromagnéticas - são pulsos energéticos capazes de se propagar no vácuo.

Oxigênio - elemento químico abundante na crosta terrestre, indispensável à vida de animais e vegetais. Ele tem número atômico 8 e número de massa 16.

Oxidação - reação de um elemento químico na qual pode ocorrer perda de elétrons, ou formação de composto com oxigênio. É o processo inverso ao da redução e aumenta o número de oxidação devido à perda de elétrons.

Panela - recipiente quase sempre redondo, largo e de altura variável, dotado de alças, orelhas ou cabos, e que é utilizado para processamento ou transporte de material em seu interior.

Perfis Normais - Com seção mais elaborada, como cantoneiras, T, Z, U, etc., com altura da alma maior que $80 \mathrm{~mm}$.

Placas - Seção retangular com espessura entre 50 e $230 \mathrm{~mm}$ e 610 a $1520 \mathrm{~mm}$ de largura.

Plasma - gás altamente ionizado e cons- tituído por elétrons e íons positivos livres, de forma que a carga elétrica total é nula.

Polím eros - materiais que não são metálicos e nem cerâmicos. Eles são derivados de carbono, ou seja, contem carbono em suas estruturas químicas de monômeros que se repetem, formando moléculas de alto peso molecular.

Poluịção - é a degradação das características físicas ou químicas do ecossistema, por meio da remoção ou adição de substâncias denominadas poluentes.

Ponto eutético - e o local do diagrama de uma liga metálica binária que apresenta o menor ponto de fusão.

Processo - conjunto de etapas que visam a transformação num material para agregar valor.

Prod ução - é aquilo que é produzido pela natureza, homem ou máquina. Também é a quantidade de produto fabricado.

Produção seriada - é a fabricação de algum produto em escala de média ou grande quantidade.

Produtividade - É a relação entre o que é produzido e o tempo gasto para produzir, então, a quantidade fabricada num período dividido pela quantidade de operários necessários para a fabricação mencionada.

Propriedade de um material - são as características comuns a determinado tipo de material.

Propriedades mecânicas de um 
material - são os comportamentos que o material apresenta quando sujeito a cargas ou forças externas. Mede-se a capacidade de transmitir forças sem se fraturar ou se deformar de forma incontrolada.

\section{Propriedades químicas dos mate-}

riais - comportamentos característicos de uma substância quando esta se encontra na presença de uma outra substância.

Química - ciência que estuda a composição, estrutura, propriedades da matéria bem como as mudanças sofridas por ela durante as reações químicas

Reação - é uma transformação da matéria na qual ocorrem mudanças qualitativas na composição química de uma ou mais substâncias reagentes que são transformadas em produtos.

Reação sólida - é a transformação de uma fase em outra com estrutura cristalina diferente em estado sólido.

Reator - é um recipiente onde ocorrem reações químicas, transferências de massa e calor.

Recozimento - é um tratamento térmico no qual ocorre a transformação dos grãos que constituem o aço de modo que os grãos se tornam homogêneos e maiores em tamanho. Este fato favorece a deformação plástica do material que passa a ficar mais macio. Em relação às estruturas existentes anteriormente ao tratamento, eles perdem as configurações anteriores obtidas por exemplo pela deformação, ou de fundição ou laminação e passam a ter grãos equiaxiais.

Redução - é o processo inverso da oxidação e pode ocorrer com ganho de elétrons, reação com hidrogênio ou com perda de oxigênio.

Refratárīo - material cerâmico formado por óxidos que vão resistir a altas temperaturas. Podem-se fabricar com refratários: tijolos refratários, cadinhos refratários para fusão de metal, barquinhas refratárias para aquecimento de material no seu interior, massas refratárias para unir os tijolos refratários e para selar regiões entre os tijolos mencionados.

Resistência elétrica - é a capacidade de um corpo qualquer se opor à passagem de corrente elétrica mesmo quando existe uma diferença de potencial aplicada. Os materiais de resistência se aquecem com a passagem da corrente.

Revenimento - é o tratamento térmico que se segue à tempera com a finalidade de realizar um alívio de tensões no material que passou por este processo.

Serviço - é o desempenho de alguma atividade ou trabalho.

Sílica - composto oxigenado (SiO2) do silício encontrado em minerais, areias e silicatos. Pode ser empregado na fabricação de vidro.

Sistema - conjunto de componentes interagentes e interdependentes que trabalham juntos para se alcançar um objetivo comum. 
Sistema de informação - é um sistema voltado para coleta de dados, armazenamento, recuperação, processamento de dados e geração de informação para tomada de decisão.

Sistemas integrados - são sistemas que juntam informações ou materiais de diversas áreas que trabalham sequencialmente de modo a alcançar um resultado ou um objetivo final. É importante que as áreas estejam integradas para se alcançar o resultado final confiável ou da melhor qualidade, quantidade e no melhor prazo.

Solda - é a região de união entre metais que sofre solubilização, também é o material de união entre metais principalmente envolvendo fusão metálica embora existam processos de brasagem ou união a quente sem fusão.

Soldabilidade - é a capacidade ou facilidade com que os metais podem ser soldados.

Soleira - a parte de baixo ou inferior de um forno metalúrgico.

Soldagem - processo de união de metais principalmente com a fusão das partes, a ser unidas ou a adição de solda que é usado na fabricação e recuperação de peças, equipamentos e estruturas.

sólido - é um estado da matéria que tem consistência dura, compacta e maciça. Pode ter estrutura cristalina ou amorfa, mas em geral não se deforma com facilidade.

Solidificação - passagem do estado líquido ao estado sólido.

Sopro no convertedor LD - é o jateamento supersônico de oxigênio sobre a superfície do banho metálico do aço com a finalidade de fazer a conversão de gusa em aço líquido. Nos primeiros cinco minutos do sopro, ocorre a queima preferencial (em termos termodinâmicos) do silício presente e dissolvido no banho líquido. Após esse período inicial, ocorre a queima preferencial do carbono do banho que vai ter seu conteúdo baixado a níveis desejados.

Sucata - material metálico gerado pelo descarte de instalações, equipamentos, máquinas ou peças na indústria, nas organizações e nos lares.

Tarugos - Seção quadrada ou circular, entre 50 e 125 mm de lado, (ou diâmetro).

Técnica - procedimentos ligados a uma arte ou ciência.

Tecnologia - estudo sistemático sobre técnicas, processos, métodos, meios e instrumentos de um ou mais ofícios.

Tecnólogo - é um indivíduo versado em tecnologia. É uma pessoa que estudou um curso superior de tecnologia. Também é conhecido como tecnologista. Exemplo: tecnólogo em soldagem.

Têmpera - tratamento térmico de aquecimento para mudança de fase em aços que mudam sua estrutura para austenita e no resfriamento rápido não há tempo de volta para a estrutura antiga e o material se distorce e adquire propriedades de alta 
resistência e dureza.

Temperatura - é o grau de calor ou frio de um ambiente ou corpo.

Tenaz - é o alicate para manipulação de amostras para colocá-las ou retirálas de fornos

Termômetro - é um instrumento para medir a temperatura do ambiente ou dos corpos. A medição é realizada quando se atinge o equilíbrio térmico com o sistema sujeito à medição.

Termopar - é dispositivo constituído por dois fios metálicos diferentes, soldados nas extremidades que, quando submetidos a temperaturas elevadas, estabelecem uma força eletromotriz entre os metais que é proporcional à temperatura permitindo avalia-la.

Tijolos refratários - São peças com formato de tijolos que vão ser utilizadas para serem unidas por argamassa refratária e vão formar o revestimento interno de fornos metalúrgicos. Alguns exemplos de aplicação de tijolos refratários incluem: revestimento interno de fornos de tratamento térmico de aços sólidos, revestimento interno de panelas de gusa líquido, revestimento interno de carros torpedo, revestimento interno de AFs, revestimento interno de convertedores LD, revestimento interno de panelas de aço, revestimento interno de distribuidores de lingotamento contínuo, revestimento interno de fornos de reaquecimento de placas ou lingotes etc.
Tipos de refratários - os materiais refratários podem ser conformados ou não-conformados (ou monolíticos). A composição é conforme a aplicação ou finalidade, o meio e a temperatura na qual será empregado. São exmplos de materiais cerâmicos: os silico-aluminosos, os cerâmicos de zirconita etc.

Tiras Laminadas a Quente - largura entre 610 a $2438 \mathrm{~mm}$, espessuras entre 1,19 a $12,7 \mathrm{~mm}$.

Tiras Laminadas a Frio - larguras entre 400 e 1650 mm, espessura entre $0,358 \mathrm{~mm}$ e $3 \mathrm{~mm}$.

Torno - máquina-ferramenta que existe nas oficinas mecânicas para fabricação de peças por rotação. Ela é provida de um eixo horizontal rotativo: a peça presa roda e aproxima-se dela a ferramenta de corte que irá lacando ou cortando pedaços que saem na forma de cavaco, fazendo com que a peça alcance o formato final.

Tração - é força de puxar. Ela é aplicada força aplicada sobre um corpo numa direção perpendicular à sua superfície de corte.

Tratamento térmico - é um conjunto de operações de aquecimento e resfriamento realizadas em materiais que podem passar por transformação de fase cristalina do material e esses processos térmicos permitem que ocorram as "reações sólidas" ou no estado sólido do material.

Tratamento superficial de metais - Fosfatização, anodização, cromatização e 
silanos são tratamentos prévios à pintura para melhorar a adesão da tinta ao metal.

Trefillaria - fabricação de arames, cabos e fios metálicos.

Tungstênio - elemento químico de número atômico 74, cujo símbolo é W. É empregado na fabricação de filamentos de lâmpadas incandescentes, elétrodos, partes de foguetes, partes de aviões a jato, aços etc.

Usina - é um local ou fábrica onde se processa a transformação de matéria-prima em produtos.

Usinagem - trabalho mecânico com metais que podem incluir: torneamento, fresagem, furação, esmerilhamento etc.

Vis cosida de - é a medida da resistência interna de um material fluído ou pastoso ao seu movimento. 


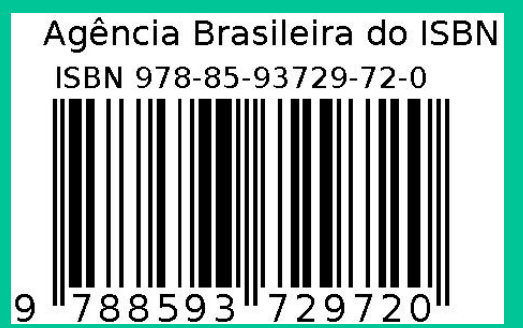

